\title{
A STUDY OF THE FLORIDA NATURAL SPONGE INDUSTRY WITH SPECIAL EMPHASIS ON ITS MARKETING PROBLEMS
}

\author{
By \\ JOHN VASIL PETROF
}

\begin{abstract}
A DISSERTATION PRESENTED TO THE GRADUATE COUNCIL OF THE UNIVERSITY OF FLORIDA

IN PARTLAL FULFILLMENT OF THE REQUIREMENTS FOR THE DEGREE OF DOCTOR OF PHILOSOPHY
\end{abstract}

UNIVERSITY OF FLORIDA

June, 1967 
UNIVERSITY OF FLORIDA

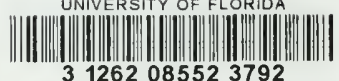




\section{ACKNOWLEDGMENTS}

The author is greatly indebted to members of his doctoral committee, Dr. Carter C. Osterbind, Dr. Myron S. HeIdingsileld, Dr. Ralph H. Blodgett, Dr. Charles W. Fristoe, and Dr. John H. James, for the guldance they have provlded during the writing of this disgertation. He 1s particularly grateful to Dr. Carter C. Osterbind who encouraged the writer to undertake the present study and from whom the writer learned the first elements of the fishing industry. The author also wishes to express his gratitude to the many I1shermen, packers, and distributors in the sponge industry, without whose cooperation much of the information presented in the following pages would not have been avallable. Equally real is the author's debt to the staff of the Bureau of Comercial Fisheries, United States Department of the Interior for providing him with the financlal assistance which made th1s study possible. Lastly, the author wishes to thank his wffe for her encouragement and assistance during the preparation of this manuscript. 
PREPACE

The sponge Industry in the UnIted States is located primarily on the west coast of Florida in Tarpon Springs. Around the turn of the century the industry was established by imulgrants of predominantly Greek origin from southeastern Europe, and their old-world methods of operation are still being used. From the time of 1ts establishment unt1I World War II the Industry experienced an increasing amount of sales and prosperity. For example, during the 1940's sales of natural sponges climbed to approximately $\$ 3$ million annually.

After reaching their peak in the early 1940 's sponge sales have declined up to the present time. Annual sales of domestic natural sponges have dropped from the 1r approximately $\$ 3$ million peak to an average annual f1gure of less than $\$ 400,000$ between the years 1960 and 1963.

Persons engaged in the business of harvesting and selling sponges realize the existence of a problem, but they disagree concerning 1ts causes and solutions. Some 1ndustry members attribute the decline in sponge sales primarily to the invention of artificial sponges, whereas others see an inadequate supply of divers as the maln cause of their predicament. Suggested solutions include tariff protection, 1mportation of midale-aged divers from the eastern Mediterranean, and pcrcrnnent support of sponge prices.

Confusion and diversity of opinton prevent spongers from taking steps toward a constructive solution of their problems. The bulk of 
the research that has been conducted on the sponge flsherles has emphasized the blological aspects of the Industry. The economic aspects of the Industry have elther been totally 1gnored or hove been touched upon only incldentally. The purpose of this study is to analyze the neglected economic and marketing aspects of the netural sponge Industry and to attempt to determine the real causes of 1 ts problems. With the exception of landing statistics there is virtusily a complete lack of information on the sponge flsheries between the years 1908 and 1937. Inasmuch as no such work has been undertaken before, an attempt has been made to bring together, analyze, and evaluate all factors of economic slgniflcance pertalning to the Florida sponge industry at Its various stages of production and ditribution. Because of the scarclty and fragmented nature of the avallable statist1cs on the sponge fisheries, past and present data have been supplemented by information obtained through interviews conducted with fisherwen, packers, and sponge distributors and by the personal observation of the author. For example, most of the material presented in Chapter III 18 based upon Information obtalned from a sample of better than 80 per cent of the diving craft operating in the sponge I1sheries In the sumer of 1964. Also, to obtain material in Chapter IV 1t was necessary to interview the entire packer population in Tarpon Springs, Florida. The section on distributors 18 based upon personal interviews conducted by the author in New York and New Jersey. Tbese interviews covered 30 per cent of the total distributors in the United States; however, according to trade association offlclals this 30 per cent sample 1s responsible for more than 80 per cent of the sponge sales at 
the distributor level. S1milarly, the information on the operations of the Tarpon Springs Sponge Exchange and the Sponge and Chamols Inst1tute were obtained through Interviews with the officisis of these organizations and through personal observations by the author.

Forelgn competition and competition by artificial substitutes have also been examined in order to evaluste their impact on the natural sponge Industry of Florida. Information on forelgn competition was obtained through correspondence w1th U. S. Department of State offlcials in sponge-producing countries and forelgn government officlals of such countries. Such inforation was further supplemented by correspondence and personal interviews with U. S. Custorns officisis and International Trade speclalists in Atlanta, Georgia. Data on synthetics were obtalned through correspondence with home offices and Interviews with the regional representatives of the major synthet1c producers in Atlants, Ceorgla.

Because of such factors as the very small size of the populations involved, the great length of time spent in contacting individual respondents, the language problem, and the lengthy and wide-ranging nature of the responses, it was not practical to attempt to crystallize the data-gathering process into formal questionnaire form; therefore, most of the prepared questionnaires were used loosely as interview guldes (see Append1x A).

The results of the present study have led to the identification of the problems of the sponge industry and to recamendations which, It is hoped, will benefit the Florida sponge interests in the long run. At this stage It may be useful to point out that the recomended 
course of action may not completely solve the problems of the sponge Interests in Flor1da; however, correct problem recognition is of paramount importance in determining any future course of action for the Florlda sponge Industry. 


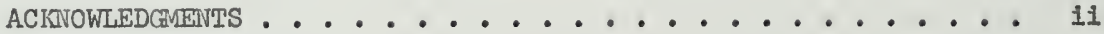

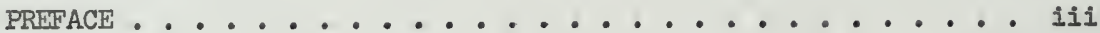

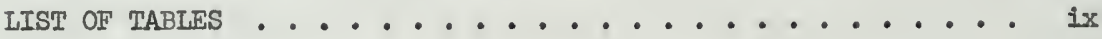

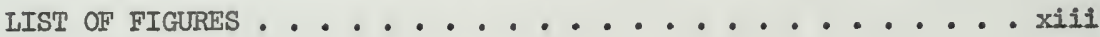

Chapter

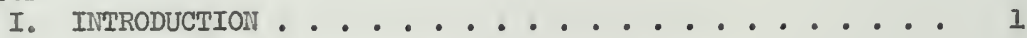

Historical Utillzation of Natural Sponges. . . . . I I

Description of the Natural Sponge. . ....... 3

Commerclal Kinds of Natural Sponges. . ....... 5

Qualities Affecting the Value of Natural Sponges . . . 16

Geographical Location of Natural Sponges in the

United States. ............ 19

II. ECONOMIC HISTORY OF THE SPONGE INDUSTRY . . . . . 21

Historical Development . . . . . . . . 22

Early Period, 1895-1937. . . . . . . . . 28

The Period from 1937 to $1964 \ldots . . . . . . .448$

Importance of the Sponge Industry to Florida and

the United States. . . . . . . . 77

III. THE PRODUCTION OF NAIURAL SPONGES ......... 81

Sponge Fishing Methods and Auxiliary Procedures. . . 81

Units of Operation ................ 84

Dependability of Supply. . . . . . . . . . 94

Comparison with Earnings in Fisherles. . . . . . 102

IV. THE MARKETING OF NATURAI SPONGES . . . . . . 107

The Tarpon Springs Sponge Exchange . . . . . 108

Prckers. ............... 111

The Sponge and Chamois Institute ......... 123

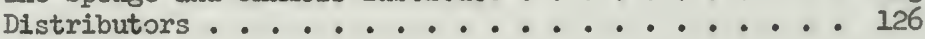

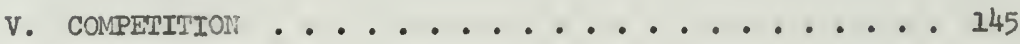

Imports................ 145

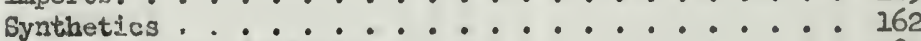

Protection and subsidies .......... 180 


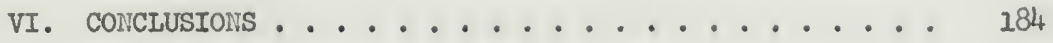

Supply and Demand............................. 184 Distribution Structure. ........... 193 Product Trend ................... 195

vII. RECOMERDATIONS .................. 200

Marleting . . . . . . . . . . . . . 200

Production. . . . . . . . . . . 209

Adjustments ............................ 211

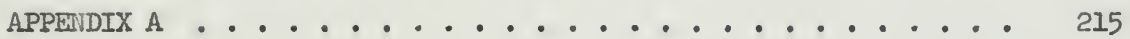

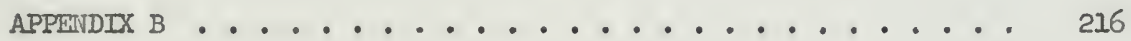

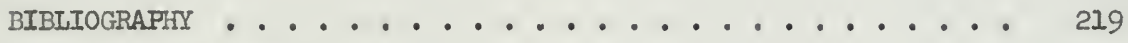

BIOGRAPHICAI SKETCH . . . . . . . . . . . 227 


\section{LIST OF TABLES}

Table

Page

1. Comron English, Sclentiflc, and Forelgn Names of Commerclal Sponges with Their Sources of Supply ........................

2. Welght, Value, and Average Price Per Pound of Wool, Yellow, Grass, and Other Sponges Landed in Florida, 1895-1908 ...............

3. Percentage Distribution of Catch and Value of Landings by Method of Operation, 1905-1908 ......

4. Indexes of the Nimber of Craft by Method of Operation of Total Bmployment and Investment in the Florida Sponge Industry for Avallable Years, 1880-1963...............

5. Semi-Annual Operating Expenses of 49 Diving Craft In PInellas County, January 1 - June 30, 1934 . . . 40

6. Fishemen Employed in Commercial Fisheries in Florida, Selected Years, 1890-1962 .......... 42

7. Number of Craft and Nomployment by Method of Operation, 1895, 1900, 1903-1908 ..........

8. Average Catch Per Hooking Craft, 1895, 1900, $1903-1908$

9. Average Catch Per Diving Craft, 1905-1908 ....... 47

10. Welght, Value, and Average Price Per Pound of Wool, Yellow, and Grass Sponges Landed in Florida, 1913-1963 . . . . . . . . . . . .

11. Catch of Wool, Yellow, Grass, and Other Sponges by Hooking Outfits, 1937-1962

12. Catch of Wool, Yellow, Grass, and Other Sponges by Diving Outfits, 1937-1962 ............

13. Percentage Distribution of Wool, Yellow, Grass, and Other Sponges by Method of Operation, 1937-1961 
14. Number of Craft and Euployment by Method of

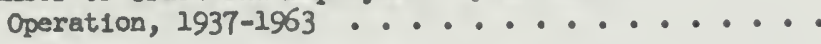

15. Average Landings Per Diving Craft, 1937-1962 ....

16. Average Landings Per Hooking Craft, 1937-1962 ....

17. Percentage Distribution of Landings and Value of Landings by Method of Operation, 1937-1963 . . .

18. Average Operating Bxpenses of Mine Diving Craft, 1963

19. Quantity and Value of Landings by Commercial

Flsheries in Florida, Selected Years, 1880-1952 ...

20. Indexes of quantity and Value of Landings by Commerclal Flsheries in Florida, Selected Years,

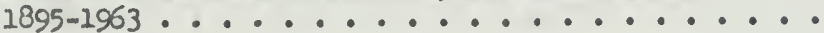

21. Indexes of Production and Average Price Per Pound of Florida Sponges, Selected Years, 1896-1963 ...

22. Florida Landings by Months, 1961-1964 . . . . . . 102

23. Sponge Landings by Months, 1961-1964 ....... 103

24. Average Price Per Pound Recelved by Sponge Fishermen and by F1shermen in the United States, 1946$1962 \ldots . . \ldots \ldots$

25. Total Number of Full-Time and Part-T1me Bmployees of Eleven Packing Firms in Tarpon Springs, Florlda, and The1r Relationship to the Owner ....... 116

26. Packer Sales by Line of Product, $1963 \ldots 118$

27. Financial Strength of Eleven Sponge Packers in Tarpon Springs, Florida, 1963 .........

28. Surmary of Operating Expenses of One Packing Firm

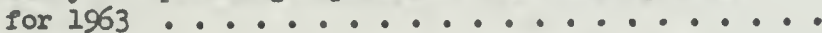

29. Domestic and Imported Sponges as a Percentage of Total Supply, 1934-1963 ...........

30. Sales in Dollars of Natural Sponges, Synthetic Sponges, and Chamols at the Dlstributor Level, 1951-1964 ............... 
31. Diatributor Sales of Natural Sponges, Synthetic Sponges, and Chamols as a Percentrge of Total Sales, 1951-1964 .............

32. Distributor Seles of Natural Sponges by Type of Customer, 1962-1964 ............

33. Distributor Sales of Natural Sponges to Trade Customers ................

34. A Comparison of Average Per Pound Prices of Domestic and Imported Sponges, 1934-1963 ......

35. Financial Strength of Natural Sponge Distributors Who Are Members of the Sponge and Chamo1s

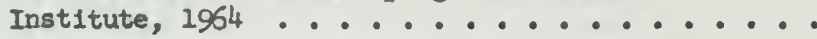

36. Unlted States Imports of Sponges by Country of

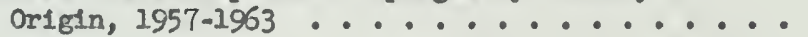

37. Greek Sponge Production, Total Bxports, and Exports to the Undted States, Selected Years, $1936-1963$

38. Sponge Trade w1th Greece, 1956-1963 ........

39. Total Avallable Supplies of Sponges in the United States from Production and Imports, 1934-1963 ...

40. Total United States Imports from Cube and the Bahamas, Selected YearB, 1934-1963 .......

41. United States Imports of Natural Sponges from the Bahamas, 1956-1963 ...........

42. United States Imports of Natural Sponges from Cuba, 1956-1962

43. Imports of Synthet1c Sponges in Dollars, 1956-1963 .

44. Marine Sponges: Untted States Rates of Duty Existing on January 31, 1965, as Defined in Sec. 256(4) of the Trade Expansion Act of 1962 . .

45. Synthet1c Sponges: United States Rates of Duty Existing on January 31,1965 , as Defined in Sec. 256(4) of the Trade Bxpansion Act of 1962 . .

46. Federal Government Purchases of Natural and Synthetic sponges, selected Years, 1948-1964 .... 
47. Cellulose sponge Sales, 1953-1962 ........ 187

48. Annusl Percentage Change in Sponge Landings and in Average Sponge Prices, 1941-1946 ....... 188

49. Surmation of Sponge Sales in Harrisburg ..... 192

50. Sponge Purchases for 1963 by Eleven Packing Firms in Tarpon Springs, Florida ......... 195

51. Computation of Least Squares Straight-Line Trend of Natural Sponges ........... 199

52. Number of Tourists, Tourist Expenditures, and Tourlst Expenditures for G1fts and Souvenirs, Selected Years, 19e9-1963 ......... 206

53. Number of Souven1s and G1ft Shops in Florida ... . 208 


\section{LIST OF FIGURES}

F1gure

Page

1. Value and Welght of Landings in the Florida Sponge

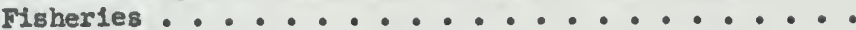

2. Per Craft Landings and Value of Landings by Kethod of Operation in the Florida Sponge Fisheries ... . 34

3. Average Sponge Prices and Value of Landings Per Flsherman by Method of Operation . . . . . . . 35

4. Euployment by Method of Operation in the Sponge Flsheries of Florida

5. Value and We1ght of Landings in the Florida Sponge Fisher1es............... 50

6. Average Landings Per Enterprise Unit in the Sponge Fisheries of Florida

7. Number of Hooking and Diving Craft in the Sponge Fisherles of Florida . . . . . . . . . . . .

8. Tumber of Hooking Craft and Landings Per Hooking craft in the Sponge Flsherles of Florlda ......

9. Number of Diving Craft and Landings Per Diving Craft in the Sponge Flsheries of Florida ......

10. An Equilibriun Model for the Sponge F1sheries of Florida

11. Value of Average Landings Per Bnterprise Unit in the Sponge Flaberies of Florida ...........

12. Value of Average Landings Per Fisherman in the sponge F1sheries of Flor1da ..............

13. Monthly Comparison of Total Florida Landings and Sponge Landings, 1961 . . . . . . . . . . .

14. Monthly Comparison of Total Florida Landings and Sponge Landings, 1962

15. Monthly Comparison of Total Florlda Landings and Sponge Landings, 1963 
16. Monthly Comparison of Total Florida Landings and

Sponge Landings, $1964 \ldots . . . . . . . . . . .998$

17. Sponge Landings by Months, 1961-1964 ........ 99

18. A Comparison of Average Per Pound Prices Received by Fishermen and Sponge Fishermen in the United

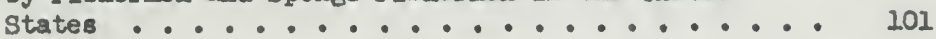

19. A Comparison of Average Per Pound Prices of Domestic

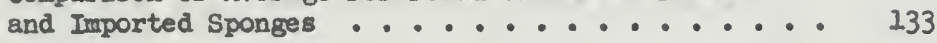

20. Relationship of Synthetic Sponge Sales to the Sales of Chamois .................... 142

21. Least Square Straight-Line Trend of Natural Sponge Consumption in the United States ....... 198 


\section{CHAPSER I}

\section{INTRODUCIION}

\section{Historical Ut1lization of Natural Sponges}

The natural sponge has been known and traded in the Moditerrancan for thousands of years. Heny ancient Greek excavations have uncovered pictures of sponges. According to Homer, Hepaestus used a sponge to wash off the grime of the smithy, ${ }^{l}$ and the housemaids of Penelope and Odysseus used sponges in cleaning dining tables." Ar1stotle mentions Greek soldiers padding their greaves and helmets with sponges they called "Achilelon."3 According to Pliny, Romans used sponges as paint brushes and maps, and Roman soldiers carrled a plece of sponge rather than a cup for drinking purposes. " This early usage is further verifled by the Blble ${ }^{5}$ it describes the way in which Roman soldiers gave Chr1st vinegar to drink from a sponge while Be was on the cross.

IA. T. Murray, The Illiad (Cambridge: Harvard University Press, 1935), p. 329.

2A. T. Murray, The Odyssey (Cambridge: Harvard University Press, 1931), p. 369.

3A. H. Stuart, World Trade in Sponges, U. S. Dept. of Commerce Industrial Serles No. \&2 (Washington: U. S. Government Printing Office, 1948), p. 4 .

4 "Sponges," Encyclopaedia Br1tann1ca, 1963 ed., vol. XXXI.

5ark 15:36. 
In the thirteenth century Arnold of V111a Nove introduced the "burnt sponge" as a mediclne to be taken internally for scrofula, tuberculosis of the Iymphatic glands. Any therapeutic effect can probably be attributed to a high content of lodine which is present in the "burnt sponge" in the form of NaI. ${ }^{1}$

The first sponges used by man were probably those washed ashore by storms; however, as was polnted out prevlously, sponge flshing has been known since the early days of man's civilization. The first deliberate efforts to obtain sponges were those of naked alvers who dived by using heavy stones as welghts in order to reach the depths of the sponge beds. 2 According to legend, numerous divers' Ilves vere sacrificed in supplylng the sponges for the baths of empresses, such as Messalina and Cleopatra. ${ }^{3}$

In modern times, besides obvious tollet and household uses, sponges are used for many purposes, such as the washing of cars, the manufacture of speclal surglcal and hyolenic preparations, the application of glaze to fine pottery, leather dressing, and the manufacture of electric chairs. They are extensively employed by garages, t1le and bricklayers, painters, 11thographers, decorators and vindow washers, although all of these markets have been constantly shrinking for reasons to be explained later in this study. 4

\footnotetext{
I"Sponges," Encyclopaedla Britannica.

${ }^{2}$ Stuart, p. 4 .

3 Irb1d.
}

${ }^{4}$ John F. Storr, Ecology of the Gurf of Mexico Comercial Sponges and Its Relation to the Flshery, U. S. Fish and Wlidife Service Special Sclent1PIC Report, Flsherles Ho. 465 (Washington: U. S. Government Printing Offlce, 1964), pp. 63-65. 


\section{Description of the Natural Sponge}

Although ancient Greeks called the sponge "zoo-phyton," I a name which implies part animal and part regetable, in the past many people regarded sponges as vegetable because of their stationary nature. In 1765, John Ellis was the first to discover the antmal nature of sponges by observing the water currents produced by a sponge and noticing the contractions on the surface of 1 ts body. ${ }^{2}$ Today sponges are considered to be one of the simplest forms of animal life and are classified as Porifera. 3

Persons who have seen sponges displayed in stores would not recognize the antmal as it comes from the ses. The live sponge is an animal with a solid and fleshy body. Its color varles in a considerable range from graylsh yellow to brownlsh black. Its form varles from cup-shaped to spheroldal and cake-shaped, depending on the specles, age, and subsurface environment. ${ }^{4}$ The marketed sponge is merely the skeleton of the living animal. This skeleton is composed of a substance similar in chemical properties to silk, horn, and chitin which is the basic material that forms the shells of insects and crabs. This aterial is distributed in a fibrous network in sponges, usually In accordance with a definfte general pattern in each species; the diameters of the fibers, the sizes of the meshes, and the relations

${ }^{1}$ George Frantzis, Strangers at Ithaca (St. Peteraburg, Fla.: Grest outdoors Publishting Co., 1962), p. I27.

2 "Sponge," National Encyclopedia, 1945 ed., Vol. IX.

${ }^{3 \text { Ibid. }}$

${ }^{4}$ stuart, p. 25. 
existing among the various fibers in each species lie within more or less well-fixed limits. In addition, the maln flbers always contain some forelgn matter, such as sand grains and insects. ${ }^{1}$

An examination of the Ilving sponge shows it to be covered by a skin raised periodically into blunt little cones over the ends of the supporting skeletal f1bers. D1stributed over the surface are sievelike membranes, whose small pores lead Into cavlties lylng just below the skin. From these cavities cansls lead Into the substance of the sponge, opening by several minute pores into many small chambers, which from their opposite ends discharge through larger openings. The cansis gradually increase in diameter unt1l they reach the surface of the sponge as large conspicuous pores known as "oscula," or, as the spongers call them, "eyes." The position and distribut1on of such oscula depend on the species. Bach osculum is surrounded by a smooth membrane which by expansion or contraction varies the size of the opening. ${ }^{2}$

Through this canal system feeding and respiration are accomplished by the sponges in the following fashion. The small chrmbers described previously are lined with cells, each of which is provided with a little lash projecting into the chamber and beating in a rhytholcal manner so that a one-directional current is created. Through the action of these cello, water 1 s sucked through the pores in the surface of the sponge and Into the small chambers and then is forced Into the

Istuart, p. 26.

${ }^{2}$ Paul s. Galtsoff, Sponges, U. S. F18h and Wildilfe Service Fishery Leaflet 490 (Washington: U. S. Government Printing Office, 1960), p. 2. 
larger canals unt1l it is sent out through the oscula. Food is carried into the sponge by the water atream and waste material is discharged in the same manner. ${ }^{1}$

\section{Commerc1al Kinds of Natural Sponges}

Biologists mention the existence of more than 3,000 specles of sponges distributed throughout the world from tropical seas to polar waters. ${ }^{2}$ The presence of a hard object to whlch the sponge can attach Itself and of flowing water for flltering through its canals the microorganisms on shich it feedo are sufficient for the survival and growth of sponges. From this extravagant varlety of sponge species only thirteen are comarclally important. Elght of the thirteen comerclally important sponges which will be identifled later are avallable in Florida and cont1guous waters. Without exception all commerclal sponges grow in warm troplcel or Bemitroplcal waters. At present almost all sponge flahing operations are confined to the Mediterranean Sea, the Carlbbean Sea, and the Gulf of Nexico. ${ }^{3}$

Table 1 lists the thirteen conmercially known sponges in their conenon Bnglish, scientific, and forelga names together with their sources.

I W1Illam M. Stephens, "A Remarkable Animal-The Sponge," Sea Frontiers, X (February, 1954), 17 .

2stuart, p. 4 .

3

Stephens, Sea Frontlers, X, 20-21. 


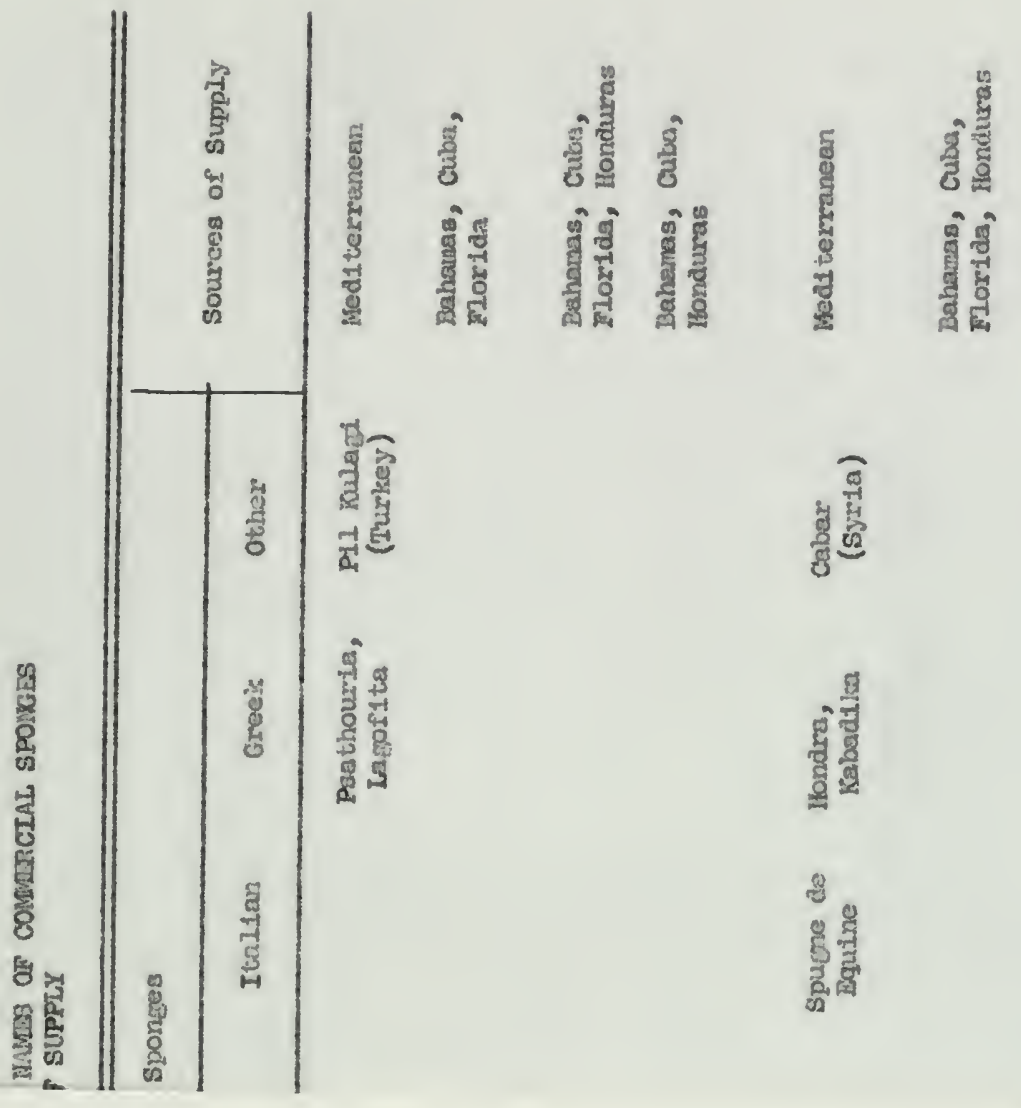



TABILE 1

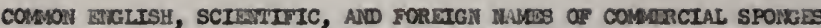
WIPT THEIR SOURCAS OF SUPPL

\begin{tabular}{|c|c|c|c|c|c|c|c|c|}
\hline \multirow[b]{2}{*}{ English } & \multicolumn{3}{|l|}{ - } & \multicolumn{4}{|c|}{ Nemes of Comberclal Sponges } & \multirow{2}{*}{ Sources of Suppiy } \\
\hline & Sclentifle & Pronch & Cuban & cerman & Italian & Greeis & Other & \\
\hline $\begin{array}{l}\text { Blephant Bar, } \\
\text { Flat Potter' }\end{array}$ & $\begin{array}{l}\text { Euspongla } \\
\text { officins } 118\end{array}$ & $\begin{array}{l}\text { Cresile } a^{\prime} \\
\text { Blephant }\end{array}$ & & $\begin{array}{l}\text { Ohrensclivamm } \\
\text { Muxdschwrem }\end{array}$ & & $\begin{array}{l}\text { Pathourla, } \\
\text { Lagofita }\end{array}$ & $\begin{array}{l}\text { P1 rulagl } \\
\text { (Iurkey) }\end{array}$ & Med1 terranean \\
\hline Clove & $\begin{array}{l}\text { U1 ppiospongia } \\
\text { Cannliculate } \\
\text { Var. Flabellum }\end{array}$ & & $\begin{array}{l}\text { Macho } \\
\text { Cuanto }\end{array}$ & & & & & $\begin{array}{l}\text { Bahmuas, Cuba, } \\
\text { Morida }\end{array}$ \\
\hline Grase & $\begin{array}{l}\text { Spongla } \\
\text { Crantinesa }\end{array}$ & Afrlque & $\begin{array}{l}\text { Macho } \\
\text { Cuove }\end{array}$ & & & & & $\begin{array}{l}\text { Baharass, Cuba, } \\
\text { rlorida, Honduras }\end{array}$ \\
\hline Hourdbead & $\begin{array}{l}\text { Sponedis Dura } \\
\text { and s. } \\
\text { Agaricine } \\
\text { Corlosia }\end{array}$ & Fine Dura & $\begin{array}{l}\text { Machito } \\
\text { Fino }\end{array}$ & & & & & $\begin{array}{l}\text { Bahanas, Cuba, } \\
\text { Fonduras }\end{array}$ \\
\hline Roneyecab & $\begin{array}{l}\text { IIpplospomgla } \\
\text { Dquina } \\
\text { Elast1ea }\end{array}$ & $\begin{array}{l}\text { Eune de } \\
\text { Syrite, } \\
\text { Fine Blonde }\end{array}$ & & Badschwang & $\begin{array}{l}\text { Spugne de } \\
\text { Equine }\end{array}$ & $\begin{array}{l}\text { Hondra, } \\
\text { Kabadika }\end{array}$ & $\begin{array}{l}\text { Cabar } \\
\text { (Syr1a) }\end{array}$ & Weds terrabean \\
\hline Reer & $\begin{array}{l}\text { Spongia } \\
\text { Ouliqua }\end{array}$ & $\begin{array}{l}\text { Fire } \\
\text { Antille }\end{array}$ & $\begin{array}{l}\text { Mecho } \\
\text { Dulco }\end{array}$ & & & & & $\begin{array}{l}\text { Baharas, Cuba, } \\
\text { Ior1da, Nondures }\end{array}$ \\
\hline
\end{tabular}




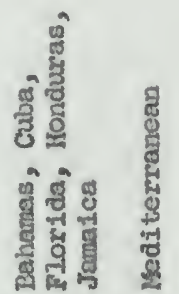

क्ष

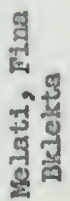

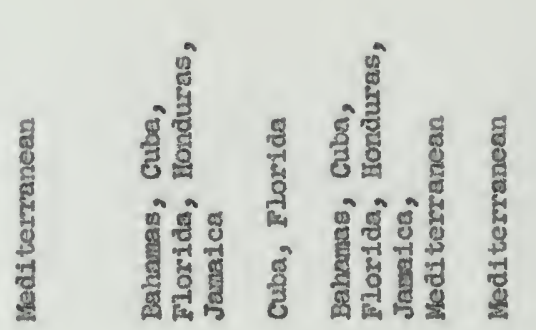

$\frac{4}{9}$

क के

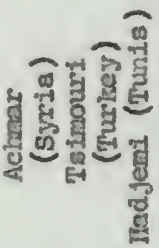

ह
$\frac{1}{9}$
हो

08 $\frac{8}{3} 4$ की क 용

둥 (1) e) 5 8 जो के 하 of 2 48 a) को ค 3 过 c) वै। fi $n$ $-8$ (4) 상 24 - 0 is 蒠 - 9 $\therefore$ 련 म ल्व 


\section{Turkey Cup sponge}

Turkey Cups are cup-shoped sponges and bring the highest prices; perfect cups are relatively rare. The oscula are comparatively large and numerous and are grouped together in the concavity of the cups, the skeletal partitions separating them being often very thin. The outer surfaces are perforated by several pores; the narrow skeletal partitions between the pores are surrounded by slender, soft, flbrous pencils. The forelon bodies in the fibers are negligible, and the in Ifbers themselves are smil in number. Such characterlstics make the Turkey Cup the softest, finest, and most elast1c sponge on the market. These sponges are used primarlly for applying cosmetics and for bathing.

Th1s sponge grows solely in the waters of the Mediterranean Sea, especially around the Syrian cosst and the 1slands of Crete and Cyprus. The best kinds of Turkey Cups are obtained in the underwater caves and crevices, where they attain a flner growth than elsewhere. ${ }^{1}$

\section{Turkey Tollet sponge}

Turkey Tollets are flatter than the cup sponges and thelr oscula are confined to the upper surface. Not as soft, fIne and elastic as the Turikey Cups, tollet sponges can be found throughout the Mediterranean. They are used for leather dressing, surgery, tollet purposes, and varlous other uses.?

$$
\begin{aligned}
& \text { Istuart, p. } 20 . \\
& { }^{2} \text { mo1d. }
\end{aligned}
$$




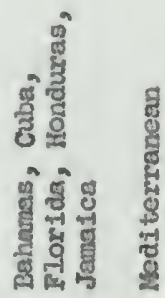

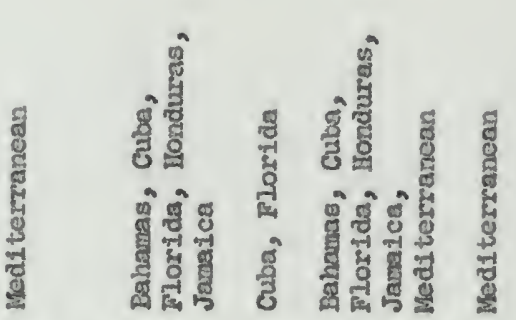

क्ष

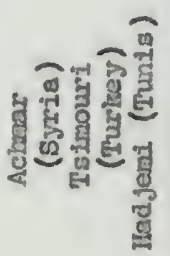

개

दु

की

发

$0^{>}$ - $\rho^{\circ}$

त्ये

है
ด्
है
है

욜 올

๑

है

g.

$8 \%$

का है

नᄀ

पु है

d

8 है

है है

떤
율
2

8

in

$\therefore$

요 


\begin{tabular}{|c|c|c|c|c|c|c|c|c|}
\hline Sheeperrool & $\begin{array}{l}\text { Hippios pongla } \\
\text { Lachne }\end{array}$ & Indienne & Derabra & & & & & $\begin{array}{l}\text { Bahocase, Cubs, } \\
\text { Flor1da, Honduras, } \\
\text { Jama1cs }\end{array}$ \\
\hline $\begin{array}{l}\text { Turisey Curp, } \\
\text { Solsd }\end{array}$ & $\begin{array}{l}\text { Euspongla } \\
\text { Officinalis } \\
\text { Nollisima }\end{array}$ & $\begin{array}{l}\text { Coupe } \\
\text { Thurque, } \\
\text { Pine Douce } \\
\text { de Syris, } \\
\text { Mne Douce } \\
\text { de Archtpel }\end{array}$ & & $\begin{array}{l}\text { Pelper } \\
\text { Ievantinerschuram }\end{array}$ & & $\begin{array}{l}\text { Melat1, Fina } \\
\text { Bklekta }\end{array}$ & $\begin{array}{l}\text { Ablund } \\
\text { (Symia) }\end{array}$ & Nodisterranean \\
\hline Turkey Tollet & $\begin{array}{l}\text { Duepongla } \\
\text { Officinalis } \\
\text { Adriatica }\end{array}$ & $\begin{array}{l}\text { Fine Douce } \\
\text { de Adriatic }\end{array}$ & & Levantinerschwang & $\begin{array}{l}\text { Spugre do } \\
\text { Begra, } \\
\text { Levantina }\end{array}$ & Molat1 & & Mediterranean \\
\hline Velvet & $\begin{array}{l}\text { Hippiospongia } \\
\text { Grossypina }\end{array}$ & Havanne & $\begin{array}{l}\text { Farao, } \\
\text { Aforsada }\end{array}$ & & & & & $\begin{array}{l}\text { Bahamas, Cuba, } \\
\text { Florida, Hondiras, } \\
\text { Jamaica }\end{array}$ \\
\hline Wire & Wot rnown & & & & & & & Cuba, Florida \\
\hline Yel110 & $\begin{array}{l}\text { Sporagla } \\
\text { Barbera }\end{array}$ & Boulet & Tachos Pino & & & & & $\begin{array}{l}\text { Baheasas, Cuba, } \\
\text { Florida, Honduras, } \\
\text { Jasalca, } \\
\text { Mediterrancan }\end{array}$ \\
\hline Zlinocen & $\begin{array}{l}\text { Duspongla } \\
\text { Z1wocea }\end{array}$ & $\begin{array}{l}\text { Chimouse, } \\
\text { Flne Dure de } \\
\text { Syrie, Fine } \\
\text { Grecque }\end{array}$ & & Z1mokkasschwaram & $\begin{array}{l}\text { Spuene } \\
\text { Zimoeca }\end{array}$ & Tsinoulan & $\begin{array}{l}\text { Acherar } \\
\text { (Syzia) } \\
\text { Tsimouri } \\
\text { (Turbey) } \\
\text { jems (Tun18) }\end{array}$ & Mediterranean \\
\hline
\end{tabular}

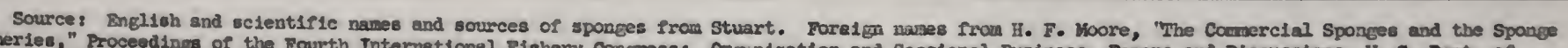
Foheries," Proceodings of the Fourth Internationel Fiehery Congress: Orginization and Sessional Business, Bapers and Discussions, U. S. Dept. of

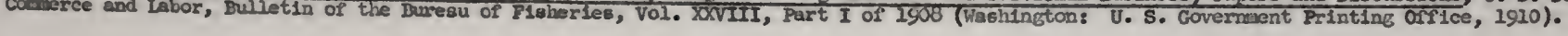




\section{Z1mocea sponge}

The Zimocca sponge is distributed throughout the Mediterranean Ses, the Adriatic Sea, the Dardanelles, and the west cosst of Asia Minor. These are massive sponges, brosder than high, with their oscula scattered over the upper surface and arranged in irregular radial rows. The Zimocca sponges are the harshest of the Mediterranean Erades. It is possible to soften them through bleaching, although bleaching reduces their durabllity. Both bleached and unbleached 2 imoccas have a relatively dark color. They are used by potters, leather dressers, and other artisans..$^{2}$

\section{Eoneycomb sponge}

Zoologists classify the Honeycomb with the Yellow sponge of the Florlda Keys; but unlike the pineapple-shaped Yellow sponge the Honeycomb is always broader than high with the oscula unevenly scattered over the upper surface. This sponge is generally distributed throughout the Mediterranean. It is a popular bath sponge and is also used by jewelers, leather manufacturers, bank tellers, et cetera. ${ }^{2}$

\section{Elephant Ear sponge}

These sponges have the shape of a rolled ear. The oscula are confined to the inside and are arranged in groups of four to $81 x$ in radial or concentric rows. The Elephant Ear is found on the coasts of North Africa and the Aegean Sea. This sponge equals the Turkey Tollet in fineness, softness, and durability. It is used for tollet

${ }^{1}$ Ibid., p. 22 .

${ }^{2}$ Ibid. 
purposes, in the medical application of electricity, by potters, fineleather workers, jewelers, and other craftsmen requiring a smooth, 11ne, soft, and durable sponge. ${ }^{1}$

\section{Yellow sponge}

There are varlous kinds of yellow sponges known in comerce. These sponges are more elastic than other western hemisphere sponges with the exception of Sheepswool sponges. They are regular in shape, attractive in appearance, and grow to a diameter of about 18 1nches. When alive they have a smooth surface and are very dark brown on top, becoming yellowish on the sides. The oscula are situated on the top of rounded cones or in the upper surface of the sponge. Yellow sponges are less durable than the sheepswool or Velvet sponges, but they are attractive and inexpensive bath sponges and are used for many other purposes. The commercial varletles of Yellow sponges are as follows: Florida Key Yellow, Anclote Yellow, Bahama Yellow, Cuba Yellow, Bonduras Yellow, and Mediterranean Yellow.

The Florlda Key Yellow is the best kind of Yellow aponge and comes from the vicinity of Matecumba Keys. Oscula are confined to the upper surface. The Anclote Yellow 18 harsher and less elast1c than the Florida key Yellow and, consequently, less valuable for comerce. Unlike the Florlda Key Yellow the oscula are not confined to the upper surface but occur all through the sponge. The Bahama Yellows are $11 \mathrm{ght}$ brown sponges w1th oscula scattered over the top surface and sometimes on the s1des. Th1s varlety of Yellow sponge is common near Andros Island. The Cuba Yellow sponge is simflar to the Anclote Yellow;

$$
\text { IIb1d., p. } 24 .
$$


however, it differs in 1ts brighter color, more cavernous structure, and greater number of oscula. The Honduras Yellow comes from the British Honduras and is harsher than the Florida Key Yellow but less harsh than elther the Bahama or Cuba Yellow. ${ }^{1}$

\section{Sheepswool sponge}

Sheepswool sponges are a product of the western Atlantic. They exhibit wide local variation, are very sensitive to environuent, and when transplanted undergo signiflcant changes in character. The oscula are large, few in number, and confined to the upper surface. The living sponge has a black color, becoming brownish at the base. Sheepswool sponges grow to over 18 inches in diameter and are unexcelled in softness, absorbency, and durabllity. They are employed for general bath purposes and for cleaning cars and other bighly polished surfaces where s1ze, softness, absorbency, and durab1lity are required. Sheepswool aponges are known under the following market varieties: Florida Rock Island, Florlda Key Wool, Bahame Wool, Cuba Wool, Mexican Wool, and Honduras Wool. 2

The Florida Rock Island is the most valuable sponge of North Amer1ca. It is found on the west cosst of Florida between Johns Pass and St. Marks. It has a groylsh brown color and the spectmens found in deep water are superior to shallow water specimens in texture, density, and durability. The Florida Key Wool comes from the Key Grounds of Florida and 18 next in value to the Rock Island, which it surpasses in softness but does not equal in strength, durability, and

\footnotetext{
Iro1d., p. 10.

2ro1d., pp. 6-7.
} 
capac1ty for holding water. The Key Wool sponges have a pale color and consist of rather weak fibers. The Bahama Wool is inferior to the two varieties mentioned previously. The best kinds are obtained from the vicinlty of Abaco and Andros Island. The Cuba Wool has the same characteristics as the Bahama specimens although it is less desirable than the Bahama. The Mexican Wool grows in shallow water and 18 the poorest of the Sheepswool sponges. It lacks softness, resillency, and durablitty. It grows from a narrow base with a rather high shape and has large oscula on the upper surface. The Honduras Wool resembles the Mexlcan Wool varlety, but it is of better quality and 18 found on the coast of Brit18h Honduras.

\section{Velvet sponge}

These sponges are found in the straits of Florlda, the Caribbean Sea, the Bahsms, and the waters off the coast of Jamalca. They were greatly decimsted by the 1937 sponge dsease and are quite scarce today. Velvet sponzes are generally cake-shaped or spheroldal, broader than high, and attached by a broad base from which the s1des swell out. The number of oscula varies from one to three on the upper surface. The color of the skeleton is 11 ght brown or dull yellow. Velvet sponges are very soft to the touch but are less resilient and absorbent than the Sheepswool. In commerce Velvet sponges are praded as follows: Florida Velvet, Bahama Velvet, Cuba Velvet, and Jamalca Velvet. 2

The Florlda Velvet is found in small quantities on the reefs between Key West and Cape Florlds. They are generally rather harsh

$$
\begin{aligned}
& { }_{\text {Ib1d., p. } 7 .} \\
& { }^{2} \text { Ib1d., p. } 11 .
\end{aligned}
$$


and more or less torn and irregular. Of the Bahama Velvets the best come from near Abaco. These are soft, moderately strong, and wellshaped sponges. The Cuba Velvet resembles the Florida Velvet but is softer. Of the Hondurse Velvet sponges the coast of Brit1sh Honduras has produced the best. The Jamalca velvet is inferior to all other Velvet sponges. Unlike other Velvet sponges the Jamaica Velvet has an upright rather than a spberoldal shape, most spectmens being decidedly columar. ${ }^{1}$

\section{Grass sponge}

Grass sponges are found commercially in Florida, the Bahamas, Cuba, Mexico, and British Bonduras. They exhibit great diversity of shape and texture but are inferior in quality, lacking in durability, usually harsh to the touch, or, if soft, exceedingly tender. Grass sponges are known under the following grades in the market: Anclote Grass, Key Grass, Bahama Grass, and Cuba Grass..$^{2}$

The Anclote Grass is the cholcest of the Grass sponges. It is shaped like a vase with inverted truncated cones deeply hollowed on the upper surface. The attached base is one-third to one-half narrover than the upper rim; the s1des are almost stralght or slightly convex, and the interior is hollowed out almost to the base. There are no oscula on the outer surface. The walls are thin at the rim of the vase and thicker toward the base. The skeletons are of a dirty brown color, harsh to the touch, and highly elastic. These sponges are used by manufacturers for cleanting purposes in machine shops

$$
\begin{aligned}
& \text { IIb1d. } \\
& { }^{2} \text { Ib1d., pp. 11-14. }
\end{aligned}
$$


since they are especially useful where there is a great deal of oll, as greasy matter is more easily washed out of them than any other sponge. For this reason and because of their stiff surfaces they are also useful for washing pots and pans in the kitchen. Almost a.ll current production, however, is sold to curlo shops along the sponge docks in Tarpon Springs. The Anclote Grass is found distributed over the entire Bay Grounds. The Key Grass is more diverse in appearance, softer, more elast1c, and less durable than the Anclote Grass. The Bahama Grass is round or cake-shaped whth numerous circular oscula located on the upper surface. The Cubs Grass is the least desirable varlety of Grass sponge because of 1 ts extremely weak fiber texture. 1

\section{Glove sponge}

Th1s species has a very interesting appearance, the sides being Iluted w1th irregular, vert1cal paralleled ridges between which 110 one or two rows of round holes from one-sixteenth to three-sixteenths of an inch in diameter. The base is almost as broad as the body of the sponge. Glove sponges are found in the Key and Bay Grounds of Florlda and in the Bahamas. The best ones come from B1scayne Bay which 18 part of the Key Grounds, wh1le those from the Bay Grounds are very poor and are rarely brought in by the spongers, who call them "bread sponges" because of the1r excessive tenderness. Glove sponges are very soft and elastic, but due to the weakness of their I1bers they are almost worthless for commerce. 2

$$
\begin{aligned}
& { }^{1} \text { Ib1a., p. } 14 . \\
& { }^{2} \text { Ib1a. }
\end{aligned}
$$


Reef sponge

These sponzes are found in the Bahamas, Cuba, and Brit1sh Honduras. Those found in Britiah Honduras are inferior to the rest. The few Reef sponges taken from the Key Grounds In Florida are not marketed as a separate specles but are Included w1th the Yellow sponges. Because of tboir limited durablilty these sponges bring a low price. ${ }^{1}$

\section{Hardhead sponge}

The Hardheads come Prom the Bahamas, Brit1sh Honduras, and Cuba. Although more durable than Reef sponges, they are very similar to the Reef sponges from whlch they are differentlated mainly by their hardness. This specles is used for activities in which great sof tness is not necessary, such as applying shoe dressings and molstening stamps in off1ces. In general, these sponges are more durable than Reef sponges. 2

\section{Wire sponge}

Th1s sponge comes from the west coast of Florids and 18 known as "bastard sheepswool" because of Its superficlal likeness to the Sheepswool sponge. In shape it is regular, broader than high, and attached by a broad base. The oscula are confined to the upper surface but are smaller and more numerous than in the Sheepswool sponge. Wire sponges are seldom brought to market, because they lack resilience, absorbency, and strength. ${ }^{3}$

$$
\begin{aligned}
& 1_{\text {Ib1d., p. } 15 .} \\
& { }_{\text {Ib1d., p. } 17 .} \\
& \text { 3Ib1d. }
\end{aligned}
$$


Qualit1es Affecting the Value of Natural Sponges

The main qualities affecting the marketability of sponges are color, size and shape, softness, fineness, durability, resillency, and absorbency. ${ }^{1}$

Color

The color of a sponge is of little importance from a functional viewpolnt, although it exerts a considerable influence on the price merely for esthetic reasons. In general, the trade prefers the lighter tones of a yellow color. A pale yellow is the most desirable color, and in order to obtain this color sponges are frequently bleached before they are offered to the ultimate user. ${ }^{2}$

\section{Size and shape}

The most desirable size, and to some extent shape, depends upon the purpose to which the sponges are to be put. For example, users w1ll prefer a smaller sponge for tollet purposes than for washing a car. Sponges up to approximately elght inches in diameter are marketed whole and are called "forms." 3 sponges above an elght-inch diameter are usually cut into pieces and are known commercially as "kuts. "14

In order to be of comercial value a sponge must be regular, massive, and free from long processes and digtations. The most

I Ioid., p. 25.

IDid.

3ro1d.

4

Irold. 
desirable sponge forze are the spberoldal and cake-shaped. ${ }^{1}$ In applying a claze to pottery, however, and in other similar work a wooth Plat surface is desired, and this is generuliy obtained elther by outting up the more masive form or by taking pleces from a woothourfaced, cup-shaped sponge.

\section{Softness}

Other things being equal, the better sponges are always softer." The extent of this characteristic depends upon the thickoses and arrangerant of the flbers and the anount of forelgn matter lncluded in them. Sponges in which the Pibers are heavily laaded with and are Invarlably harsh and connequently less desirable.

\section{Flneness}

The fineness of the spong texture differs anong the specles, the Mediterranean varieties belng superior in sineness over the rest. 3 Freness also varles within the same speles, dependiag on the exvironment under which the Individus sponge is produced.

\section{Durablilty and toughness}

These factors vary with the alferent species and are influenced by eaviromental conditions. In any elven specles, the looser the general structure and the larger and more numerous 1 t canals the more easily $1 t$ is torn and the sooner it wears out." For example, the loose

${ }^{1}$ Tb1e.

m1d., p. 26.

${ }^{3}$ Io1d.

"Ib1d. 
open-textured Sheepswool sponge of Blscayme Bay is much less durable than the denser Rock Island varlety.

\section{Restlience}

In general, sponges are more elast1c when dry, and they gain in coupressibility when wet. Good resillency is indicated when a wet sponge promptly returns to 1 ts original shape when compression is removed. Resiliency depends partly upon the size and composition of the flbers but mainly upon the thoroughness and manner of cleaning. ${ }^{1}$ Poorly cleaned sponges contain "gurry" and therefore are sluggish in returning to shape after compression. Gurry is 11quifled organic matter which results from decomposition and 18 also known as "meat" or "milk."

\section{Absorbency}

Absorbency is a result of a combination of softness, fineness, and resilleace. The quick absorbent sponges have slender fibers and close textures. The existence of large canals and cavities adversely

affects the amount of water that can be absorbed by a sponge. ${ }^{2}$ From a functional point of view this is the most important property upon which the usefulness of a sponge depends. ${ }^{3}$

$$
\begin{aligned}
& \text { IIb1d., p. } 27 . \\
& { }^{2 \text { Ib1d. }} \\
& { }^{3 \text { Ib1d. }}
\end{aligned}
$$


Geographical Location of Natural Sponges

In the United States

The sponge grounds of the Unfted States extend over the Continental Shelf from a depth of a few feet to approximately 150 feet, and they are broadiy divided into two separate areas, the Bay Grounds and the Key Crounds. The exact extent and density of the sponge population is not known, but it is belleved that these two areas cover approximately 9,300 square miles of sponge-ylelding bottom. ${ }^{1}$ An ocean floor with I1rm and clean objects is necessary for sponge growth, since sponges cannot attach themselves to sand, mud, or grass. Thus, bottom topography 18 an important factor in the determination of the sponge beds."

Sponge-bearing grounds, or "bars;" as the spongers call them, are found through the use of a "glass bucket" in shallow waters. In deeper waters they are located by means of a "sounding lead." This is a soapcovered device which, when it reaches the bottom, picks up samples of the sea floor, thus informing the crew of the presence or absence of sponges. Thls and other techniques of sponge fliking were observed by the author during several trips aboard the diving craft "Elenf" In the summer of 1954.

\section{The Bay Grounds}

The Bay Grounds are located in the open waters of the Gulf of Mexico. They begin near Johns Pass, a lew miles north of Tampa Bay, and extend a distance of 160 miles, as far as St. Marks. ${ }^{3}$ Spongers

$1_{\text {Florida, State Board of Conservation, Second Blennial Report, }}$ Blennium Ending June 30, 1936, p. 64.

\footnotetext{
2stuart, p. 2 .

3 stuart, p. 43 .
} 
divide this area into regions, such as Rock Island, Pepperfish Key, New Ground, Withlecoochee I1ght, St. Martin's Reef, Anclote Key, and H1ghlands. The better qualities of United States sponges come from the Bay Grounds, the area responsible for over 90 per cent of United States natural sponge fishing. 1

\section{The Key Grounds}

The Key Grounds consist of the reefs and keys in the inshore waters around Key West, Florida Bay, and the lower part of Blscayne Bay. 2 Some sponge bars are also interspersed in the area between Cape Sable and the mouth of Tampa Bay. Unt1l the discovery of the Bay Grounds In 1873, the Key Grounds were the only source of supply for sponges in Floriaa. 3 These Brounas now are comparatively exhausted, and they make a smaller than 10 per cent contribution to the total sponge catch. 4 Since sponges taken from the Key Grounds are found in relatively shallow waters they are inferior in durablilty and texture to Bay Ground sponges.

IU. S., Congress, House, House Miscellaneous Reports IV, 8lst Cong., 2d Sess., 1950, H. Rept. 2120, p. 2 .

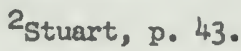

3 To1d.

4U. S., Congress, House, House Miscellaneous Reports IV, p. 2. 
CHAPTER II

ECONOMIC HISTORY OF THE SPONG INDUSTRY

The purpose of this chapter is to trace the economic developments in the Florida sponge flsheries from their inception to the present time. In any fishery natural elements, such as weather, marine diseases, and sheer luck, are important factors in determining levels of production. The importance and effect of these unmeasurable factors on sponge flining is studled through the examination of landing statistics of past years. 1

The accuracy of early fishery statistics in the Inftad Statee is questionable, and even the most recent fishery statistics are contradictory and lack the accuracy necessary for a precise description of the situation. In discussing this point, C. P. Idyll deplores the fact that in reporting landing fleures for the state of Florida, the U. S. Fish and Wildiffe Service and the State of Florida reported widely differing flgures..$^{2}$ Despite their shortcomings, hovever, such data are helpful in indicating trends and broad relationships which can be used to advantage in solving ilshery problems and in recommending alternative policles and ways of action.

Ianding flgures indicate the aggregate pounds of fishery products caught by commercial fishermen on an annual basis.

${ }^{2}$ Clarence P. Idy 11 , How Can Statist1cs Increase The Catch? Florida Board of Conservation Educational Series No. 3 (Coral Gables, Fla.: Marine Laboratory, University of Miami, 1949), p. 5. 
A historical survey of the sponge fisheries would indicate that the Ilsherles have experienced some unusual developments since 1937 , as contrasted to their normal behavior since their inception in the middle 1800 's. The year 1937 can be considered as a turning point in the sponge f1zheries; it is pertinent to analyze the industry under two time intervals: (1) the early period covering the years 1895 to 1937, and (2) the later period covering events from 1937 to the present time. 1 Although there is a complete absence of data for the years 1909-1912, it is convenient for purposes of analysis to label the entire period from 1895 to 1937 as the early period. The year 1895 was selected as a starting point, because prior to that time no statistical Information on the United States sponge fisheries is ava1lable. The historical development of the sponge flsherles will be discussed in the following section.

\section{H1storical Development}

The sponge Ilsheries of the western Atlantic have been commercially known since the $1840^{\prime} \mathrm{g}$. It was around that period that New World sponges were introduced to world markets by a grench merchant who had been shipwrecked in the Bahrmas.?

In the United States, Key Wast was the first and for many years the only sponge center. In all probablilty the natives of the keys knew about sponges and their utilization long before they became an article of coumerce, but the first shipment of sponges was sent from Key West to New York in 1849, where they were sold for ten cents

\footnotetext{
Istorx, p. 51.

2stuart, p. 4 .
} 
per pound. ${ }^{1}$ Prior to this time American demand for sponges had been satisfied through imports from the Nediterranean. 2

Beginning in the year 1895, Tarpon Spring exceeded Key West in the sale of sponges and as time passed became the center of the United States and later of the world sponge industry. At present it is estimated that more than 95 per cent of the United States sponge Iishing takes place in Tarpon Springs, Florida. ${ }^{3}$ It 18 intereating to note that despite this shift in emphasis from Key rest to Tarpon Springs, the sponge flsherles of the United States are st1ll restricted to a single state, namely Florida.

The successful sale of Key West sponges in 1849 was followed by a continuous increase in cap1tal investment and employment in the sponge fisheries of this locality. These facts were reported in the Proceedings of the Fourth International Fishery Congress; however, no specific figures were given on the amount of Increase in investment and employment. 4 At first sponges were gathered by merely pulling them out of shallow water by hand. Later, as 1t became impossible to find sponges in sufficlently shallow waters, the practice of wading had to be abandoned. In order to obtain sponges from deeper waters spongers Invented the sponge hook, a sharp hook attached to a pole of moderate length. The f1sherman would scan the botton of the ocean from

Moore, Proceedings of the Fourth International Flshery Congress, p. 425 .

Iro1d.

Interview w1th Louis Smitzes, President of Tarpon Springs Sponge Exchange, Tarpon Springs, Fla., April 6, 1954. p. 426 .

Moore, Proceedings of the Fourth International Flshery Congress, 
the bow of his boat and tear sponges loose with the hook as they came to his attention. Thus, it became possible to reach sponges at slightly greater depths.

A continuously increasing demand for sponges, coupled with the exhaustion of the shallow water beds, pushed the sponge operations into progressively deeper waters. ${ }^{1}$ It became almost impossible to scan the bottom of the ocean for sponges as spongers moved into increasingly greater depths. In order to overcome this difficulty the "glass bucket" was introduced, first about $1870 .^{2}$ This was a regular bucket with a glass bottom and is still being used today by many fishermen. By means of this ingtrument it became possible to see the bottom of the ocean up to depth of 50 feet in clear waters. In the early days wading and hooking were the only methods usec by Key West spongers. This is easily understood since the methods of the sponging industry of the United States were virtually copied from those of the Bahamas, and most of the Key lest apongers were brought in from those islands. 3 There is no record of any other changes between the years 1870 and 1905.

In the spring of 1905, a Greek named John Cocoris with the assistance of John Cheyney, a sponge dealer, decided to try sponging methods employed in the Mediterranean. 4 With this method sponge fishing can be extended to depths up to 150 feet, wheress spongers using

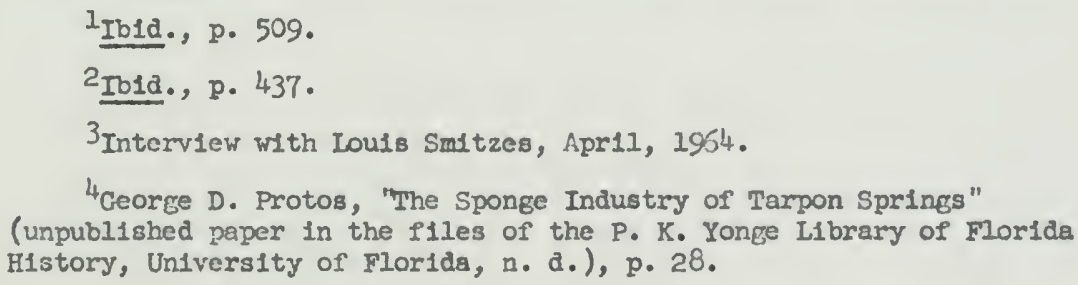


the hook1ng method cannot $g 0$ beyond a depth of 50 feet under the most favorable conditions.

John Cocoris brought and sponging materials from the old country to Tarpon Springs in order to carry out his experiment, and made his first trip in April, 1905. This first trip was so successful that by May, 1906, little more than a year later, there were 50 diving boats at work and 35 more were walting for crews to be supplied, largely from the Greek 1slands. ${ }^{2}$

The first diving boats used in Florida were locally bullt sloops which had been remodeled to fit the new requirements. It was reported that these boats were not suitable for the job; however, the author was unsble to ascertain why the earlier sloops were unfit for diving operations. The imigrants introduced boats styled after vessels in Greece. The same type boats are used by spongers today, although several improvements, such as diesel englnes and wireless communications, have been incorporated into the contemporary vessels. ${ }^{2}$

The successful use of the scaphander resulted in considerable aglation within the sponge Industry, especlally among Key West spongers using the howiting method. This is easy to understand since at that time sponge fishing was the number one industry in Key West, as is indicated by the following quotation:

\footnotetext{
Moore, Proceedings of the Fourth International F1shery Congress, p. 442 .

2Interview with Iouis Sm1tzes, April, 1954.
} 
The sponge f1shery 18 of more 1mportance to the citizens of Key West than any other branch of buslness. The outlay for supplies and utensils required by the numerous sponge fleet, amounting to $\$ 100$ or $\$ 200$ per vessel each trip, is no inconsiderable factor in the industrial condition of the place, while the large cash sums put in circulation by the sponge buyers constitute the princlpal cource of ready money for a large proportion of the population. 1

Despite the fact that Key West spongers were objecting primarily for economic reasons, they pretended to be concerned only about the conservation of the sponge beds. For example, Mr. E. J. Araplan, a wellknown Key West sponge dealer, objected to achine diving on the ground that sponges cease to grow where submarine divers have walked with the1r beavy ahoes. 2

In an attempt to lessen the animosity of the users of the hooking method, Greek divers carrled their operations well offishore into depths of 60 feet and over, but this only made matters worse because the sponges found in deeper waters were of larger size and better quality and, consequently, coumanded higher prices in the market. ${ }^{3}$

The animosity of the Key West spongers was carrled to the extent of burning Greek diving boets and Influencing the Florlda legislature In the passage of a law prohfblting the taking of sponges through diving, elther with or without the scaphander, within a three-mile limit. ${ }^{4}$ All such efforts proved to be 1asdequate in halting the progress of machine diving. Greek divers showed themselves to be superior to Key West hookers in gathering sponges, and eventually they

IU. S., Congress, The Flsh and Fisheries of the Cosstal Waters of Florida, 54th Cong., 2d Sess., 1897, Doc. 100, p. 37.

${ }^{2}$ Ib1d., p. 6. p. 441 .

3 Moore, Proceedings of the Fourth International Fishery Congress,

4Florida, Statutes (1914), c. 253.692. 
practically obtained a monopoly on all methods of sponging used on the Florida coast. ${ }^{1}$

II. F. Moore uses the following example to illustrate this fact. In 1909, the schooner "I1Imore," manned by ten Greeks, was out for 60 days and had flshed in deptins of 35 to 40 feet, bringing in sponges that were sold for a total of $\$ 2,180 .^{2}$ A non-Greek schooner with thirteen of the most skilled hookers and under one of the best captains sponged for 42 days in depths of less than 30 feet, bringing in a revenue of $\$ 1,180 .^{3}$ The second vessel ylelded $\$ 2.15$ per man-day, almost 59 per cent less than the Greek vessel which averaged $\$ 3.63$ per man-day.

In 1908, several sponge dealers took the infitiative in establishIng the Tarpon Springs Sponge Exchange. ${ }^{4}$ Prior to the establishment of the Exchange, sponges were sold at the varlous "crawls" around the c1ty. A crawl was a shore enclosure about ten feet square, constructed of stakes driven close together, In whlch live sponges were exposed to air and sun in order to accelerate maceration. As there were a number of crawls at considerable distances from each other, dealers had to waste much time in traveling from crawl to crawl. In order to obviate this Inconvenience they organized the Tarpon Springs Sponge Exchange. Th1s is a non-prof1t cooperative organfzation whose shares are owned by the sponge dealers, and 1 t is financed through a 2 per cent billing p. 441.

$1_{\text {Moore, Proceedings of the Fourth International F16hery Congress, }}$

$$
\begin{aligned}
& { }^{2} \text { Io1d. } \\
& { }^{3} \text { Io1d., p. } 442 . \\
& { }^{4} \text { stuart, p. } 35 .
\end{aligned}
$$


on the sales of each boat's merchsndise. A more detalled description of this organization is offered in Chapter IV.

The establishment of the Exchange gave Tarpon Springs a permanent lead over Key West. At present, all industry statist1cs are based on transactions which have taken place in the Tarpon Springs Sponge Exchange, and it is estimated that such transactions amount to better than 95 per cent of total Industry dealings in the United States. 1

\section{Early Perlod, 1895-1937}

\section{Production}

In 1895, the sponge f1sherles vere Florlda's most valuable fisherles w1th 306,120 pounds of landings valued at $\$ 358,871$. During that year Florida landings were $37,036,768$ pounds at a value of $\$ 1,209,725$. The value of sponge landings was approximately one-third of total landings. The landings of the next four most valuable Florida fisherles were valued at $\$ 555,086$. The mullet f1sheries were second to sponges In importance with landings valued at $\$ 310,847$, followed by red snapper landings valued at $\$ 155,346$, oyster landings valued at $\$ 61,723$, and sea trout landings with a value of $\$ 27,1700^{2}$ Table 2 contains the earllest ava1lable production stat1st1cs by spec1es for the sponge flsheries of Florida. Figure 1 indicates landings and value of landings for the period of 1895 to 1936.

\section{Ib1d., p. 45.}

${ }^{2}$ Carter C. Osterbind, Florida's Commerclal Fisheries: Markets, Operations, Outlook (State Economic Stud1es, No. 7; Gainesville, Fla.: Bureau of Economic \& Business Research, Unlvers1ty of Flor1da, 1955), p. 153. 

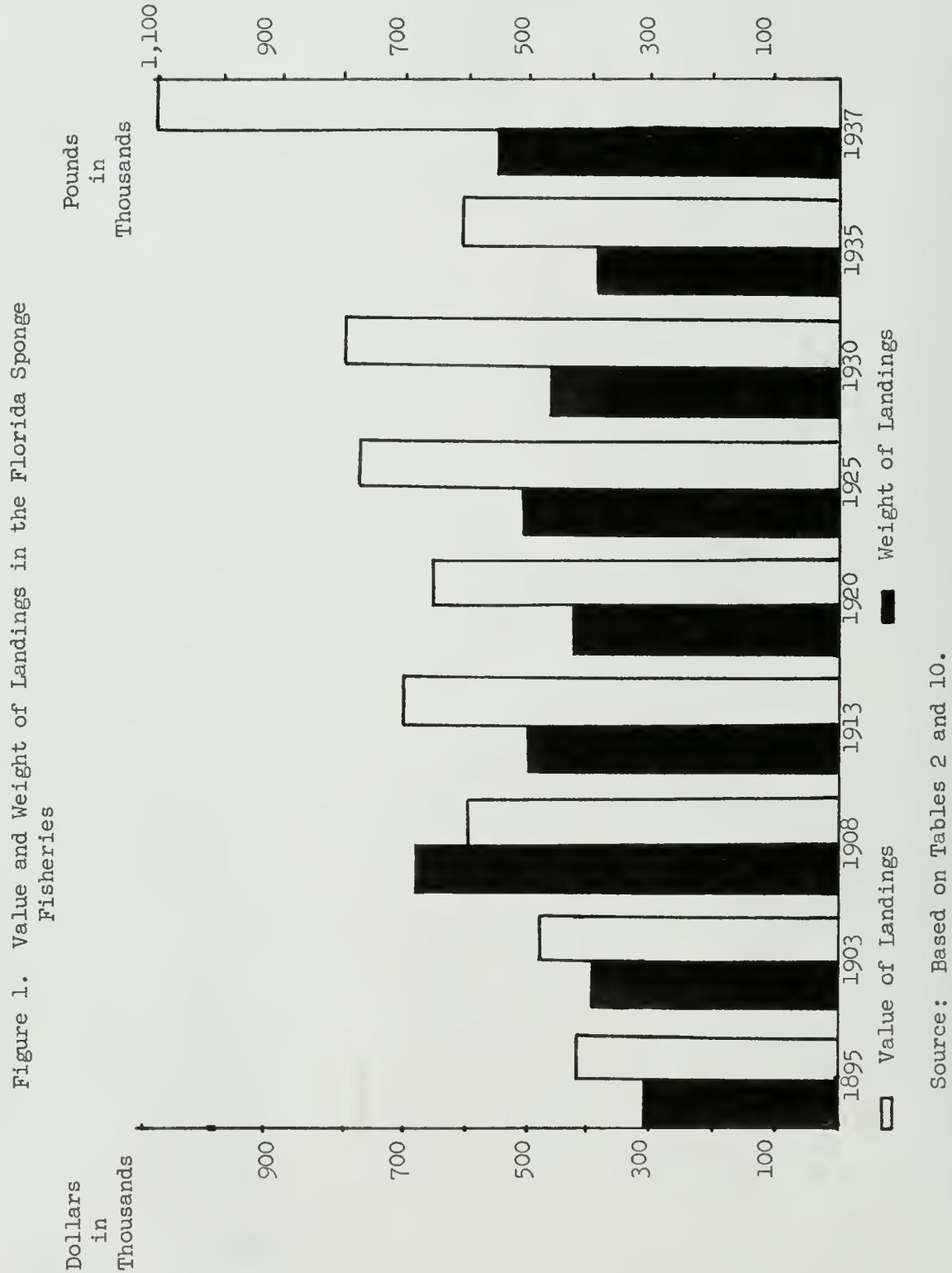
TABLE

WEIGEN, VALUE, AND AVERAGE PRICE PER POUND OF WOOL, YELIOW

\begin{tabular}{|c|c|c|c|c|c|c|c|}
\hline \multirow{2}{*}{ Year } & \multicolumn{3}{|c|}{ Wool } & \multicolumn{3}{|c|}{ Yellow } & \\
\hline & Pounds & Dollars & $\begin{array}{l}\text { Prices } \\
\text { Per } \\
\text { Pound }\end{array}$ & Pounds & DollarB & $\begin{array}{l}\text { Prices } \\
\text { Per } \\
\text { Pound }\end{array}$ & Founds \\
\hline $\begin{array}{l}1895 \\
1896 \\
1897 \\
1898 \\
1899 \\
1900 \\
1901 \\
1902 \\
1903 \\
1904 \\
1905 \\
1906 \\
1907 \\
1908\end{array}$ & $\begin{array}{c}231,272 \\
149,724 \\
157,476 \\
\ldots \\
153,700 \\
181,311 \\
\ldots \\
\ldots \\
219,334 \\
184,645 \\
235,561 \\
431,214 \\
278,334 \\
309,681\end{array}$ & $\begin{array}{c}363,107 \\
248,196 \\
240,599 \\
\ldots \\
332,390 \\
483,263 \\
\ldots \\
\ldots \\
411,562 \\
346,784 \\
483,444 \\
801,437 \\
470,076 \\
484,553\end{array}$ & $\begin{array}{c}1.57 \\
1.66 \\
1.53 \\
0.16 \\
2.16 \\
2.67 \\
\ldots \\
1.88 \\
1.88 \\
2.05 \\
1.86 \\
1.69 \\
1.56\end{array}$ & $\begin{array}{c}29,509 \\
23,655 \\
32,362 \\
\cdots \\
55,800 \\
74,466 \\
\cdots \\
6 \\
62,001 \\
47,213 \\
45,070 \\
103,938 \\
265,662 \\
190,714\end{array}$ & $\begin{array}{c}11,789 \\
9,318 \\
13,082 \\
\cdots \\
16,205 \\
44,045 \\
\ldots \\
18,390 \\
17,183 \\
19,234 \\
39,154 \\
76,955 \\
43,129\end{array}$ & $\begin{array}{l}.40 \\
.39 \\
.40 \\
. . \\
.29 \\
.59 \\
\ldots \\
.0 \\
.46 \\
.36 \\
.43 \\
.38 \\
.29 \\
.23\end{array}$ & $\begin{array}{c}21,387 \\
44,617 \\
128,622 \\
\ddot{76,900} \\
143,112 \\
\cdots \\
83,381 \\
51,977 \\
67,431 \\
46,765 \\
158,214 \\
109,617\end{array}$ \\
\hline
\end{tabular}

Source: 1895-1899 from Hugh M. Smith, Notes on the Florida Commission, Vol. XIX for 1899 (Washington: U. S. Coverrment PrintFlorida in 1900, U. S. Commission of F1sh and F1sheries extract Printing Office, 1903). 1903-1908 from Hoore, Proceedings of the 
GRASS, AND OTHER SPONGES LANDED IN FLORIDA, 1895-1908

\begin{tabular}{|c|c|c|c|c|c|c|c|}
\hline Grass & & & Other & & & Total & \\
\hline Dollars & $\begin{array}{l}\text { Prices } \\
\text { Per } \\
\text { Pound }\end{array}$ & Pounds & Dollars & $\begin{array}{c}\text { Prices } \\
\text { Pex } \\
\text { Pound }\end{array}$ & Pounds & Dollars & $\begin{array}{l}\text { Prices } \\
\text { Per } \\
\text { Pound }\end{array}$ \\
\hline $\begin{array}{r}5,464 \\
11,508 \\
29,188\end{array}$ & $\begin{array}{l}.26 \\
.26 \\
.23\end{array}$ & $\begin{array}{l}23,952 \\
18,315 \\
13,086\end{array}$ & $\begin{array}{l}6,502 \\
3,990 \\
3,171\end{array}$ & $\begin{array}{l}.27 \\
.22 \\
.24\end{array}$ & $\begin{array}{l}306,120 \\
236,311 \\
331,546\end{array}$ & $\begin{array}{l}386,387 \\
273,012 \\
286,040\end{array}$ & $\begin{array}{r}1.26 \\
1.16 \\
.86\end{array}$ \\
\hline $\begin{array}{l}14,319 \\
33,263\end{array}$ & $\begin{array}{l}\because 19 \\
.23\end{array}$ & $\begin{array}{l}18,000 \\
17,236\end{array}$ & $\begin{array}{l}5,000 \\
7,114\end{array}$ & $\begin{array}{l}.28 \\
.41\end{array}$ & $\begin{array}{c}304,400 \\
316,546\end{array}$ & $\begin{array}{l}367,914 \\
567,685\end{array}$ & $\begin{array}{l}\ldots \\
1.21 \\
1.80\end{array}$ \\
\hline .. & .. & •. & •. & . & •. & $\bullet$ & $\cdots$ \\
\hline $\begin{array}{r}14,794 \\
9,541 \\
16,166 \\
12,409 \\
30,711 \\
17,230\end{array}$ & $\begin{array}{l}.18 \\
.18 \\
.18 \\
.24 \\
.27 \\
.19 \\
.16\end{array}$ & $\begin{array}{r}13,199 \\
7,712 \\
17,030 \\
7,977 \\
1,706 \\
12,477\end{array}$ & $\begin{array}{r}2,600 \\
2,687 \\
3,812 \\
1,583 \\
408 \\
3,964\end{array}$ & $\begin{array}{l}. . \\
.20 \\
.35 \\
.22 \\
.32 \\
.21_{4} \\
.32\end{array}$ & $\begin{array}{c}\ldots \\
377,915 \\
291,546 \\
365,092 \\
589,894 \\
703,916 \\
622,489\end{array}$ & $\begin{array}{l}447,346 \\
376,195 \\
522,926 \\
854,583 \\
571,751 \\
548,876\end{array}$ & $\begin{array}{r}1.18 \\
1.29 \\
1.43 \\
1.45 \\
.82 \\
.88\end{array}$ \\
\hline
\end{tabular}

Sponge Fishery in 1899, House Documents, Bulletin of the U. S. Flsh Ing Office, 190I). 1900 from John $\mathrm{N}$. Cobb, The Sponge Fishery of Prom U. S. F1sh Cormission Report for 1902 (Woshington: U. S. Government Fourth Internationel Fishery Congress. 
The supply of sponges and of any type of fishery product depends on many factors, such as perlod of operational activity during a given yesr, condition or normalcy of the beds during the same period, and productivity of the flshing fleet during that year. Sponge fishermen have no power over most of these factors. Bad weather conditions can greatly influence the amount of time that fishermen can spend productively in retrleving sponges in any given year. Marine diseases also have an adverse effect on sponge production, because such epidemics invarlebly reduce the amount of sponges avallable for flshing.

From the inception of the industry unt11 1905, sponge flshermen ut1lized one type of gear, that used in hooking operations. Beginning In 1905, a new method of operation was Introduced to the industry, the method of retrleving sponges from the bottom of the sea through the use of submarine divers equipped with a diving sult and helmet. Machine diving used more capltal and proved to be more productive than the hooking method. After 1905, the level of production in the sponge Industry depended on the productivity of two types of gear, namely those of hooking and machine diving.

Machine diving has an advantage over hooking in the sense that falrly rough surface waters cannot prohiblt the machine divers' f1shing, whlle hooking reguires a relatively smooth surface; however, machine divers at times have been unable to locate sponge beds even under the most serene surface conditions because of poor visibility at the bottom. ${ }^{2}$

Machine divers have mentioned "milky bottoms" as a kind of submarine fog which limits visibility at the bottom of the ocean. 
Flgure 2 shows that landings per craft between 1905 and 1908 were considerably higher for diving ships than for hooking ships, indicating the superfority of the never method of operation. When the comperison Is made on a value of landings basis rather than a welght of landings basis, diving outfits Indicate an even better situation. There are three reasons for this: (1) sponges retrieved by diving bring a higher price per pound than those obtained by hooking, because deep water sponges are superior in quality to shallow water sponges; (2) in addition to harvesting more sponges, historlcally speaking, diving outfits have concentrated on the more valuable specles, such as the Sheepswool sponges; (3) sponges obtalned by diving are in better physical condition than those obtalned by hooking, since the hook used In booking operations often damages the sponges. ${ }^{1}$ Table 3 shows that with the exception of the year 1905, which marks the beginning of machine diving, the catch of diving outfits percentage-wlse has consistently exceeded that of hooking outf1ts. Figure 3 indicates that average prices recelved by diving outf1ts, although volat1le, were alwsys hlgher than those recelved by hooking outfits.

The production of sponges for the years 1895 and 1908 is shown in Figure 2. It can be seen that the introduction of machine diving gave considerable inpetus to the quantity of sponges gathered. Between the years 1904 and 1907 sponge landings incressed by 141 per cent, and the value of such landings went up by 52 per cent. Although sponge prices are determined by all of the conditions of supply and demand, one cannot overlook the importance of speciflc factors, such as sessonality, 


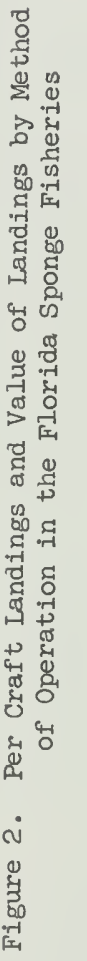

?ृ
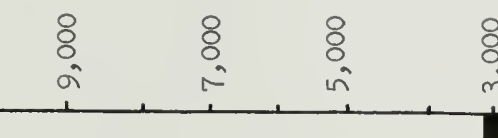

$\begin{array}{ll}8 & 8 \\ m & 8\end{array}$

i
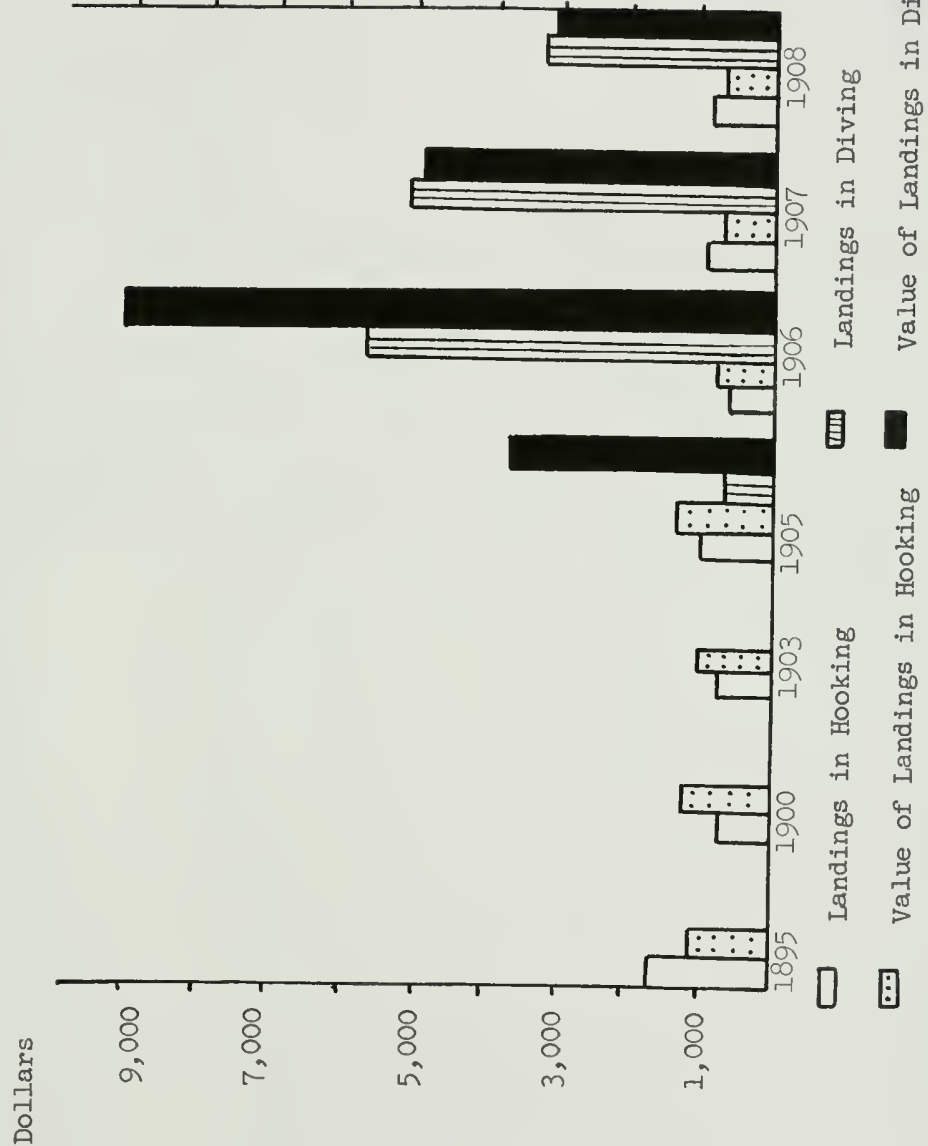

ผี
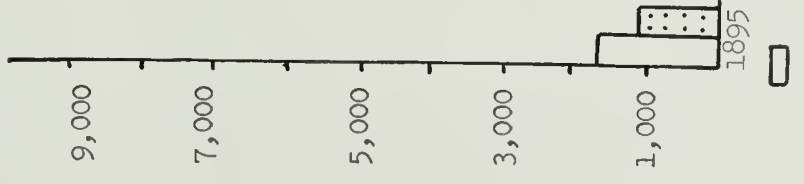

9

望
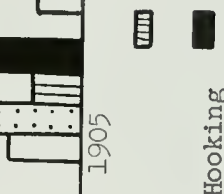

\%

की तो

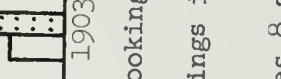

$\therefore$ द त्न मू है

[ं. 8 के क्ष

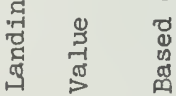

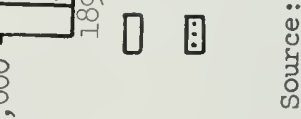



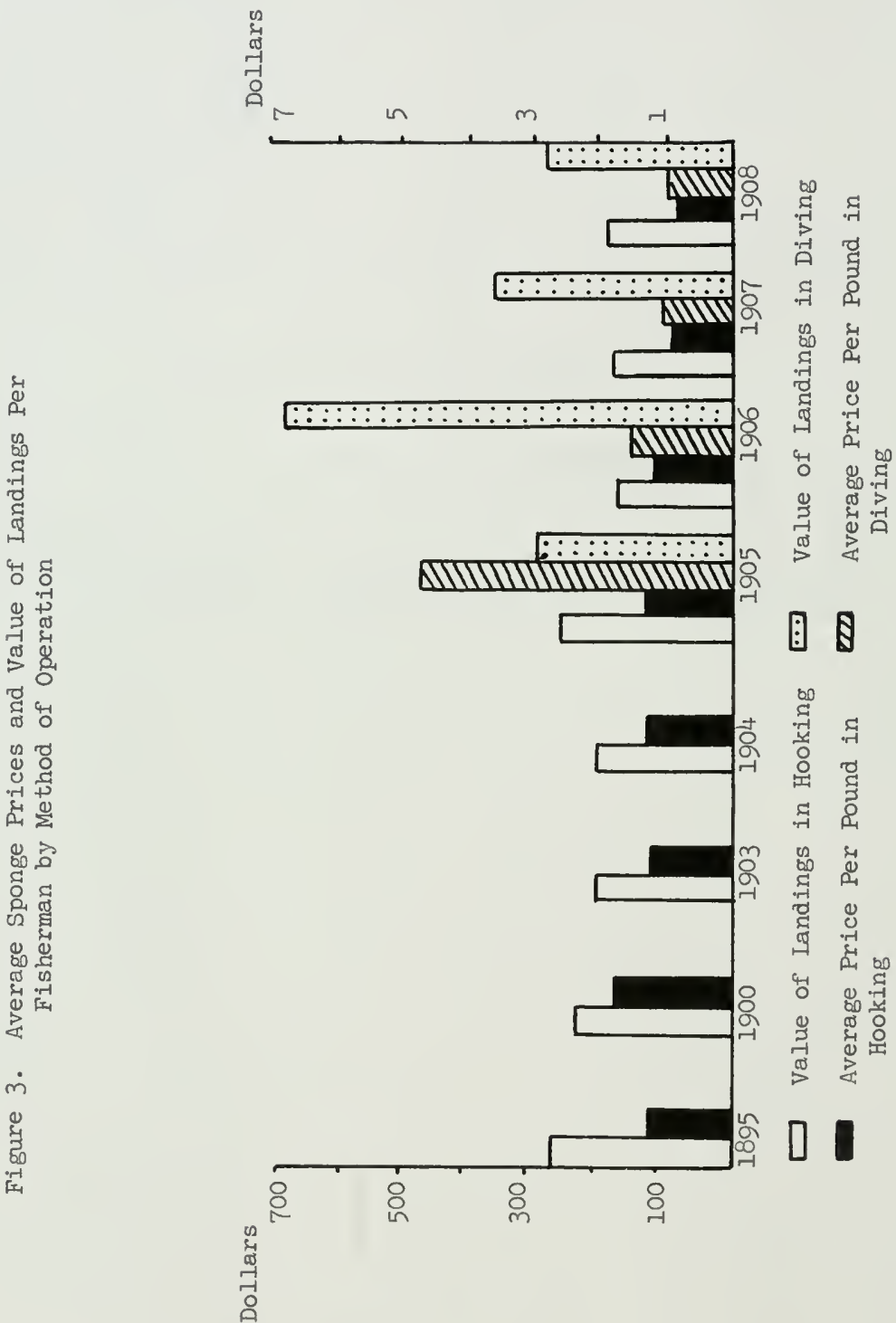

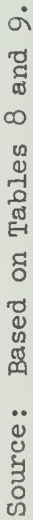


TABLE 3

PERCEMTAGE DISTRIBUTION OF CATCH AND VALUE OF

LANDINGS BY MEHHOD OF OPERATION, 1905-1908

\begin{tabular}{l|ccc|ccc}
\hline \multirow{2}{*}{ Year } & \multicolumn{3}{|c|}{ Catch } & \multicolumn{3}{c}{ Value of Catch } \\
\cline { 2 - 7 } & Hooking & Diving & Total & Hooking & Diving & Total \\
\hline 1905 & 97.29 & 2.73 & 100.00 & 90.87 & 9.13 & 100.00 \\
1905 & 39.25 & 60.75 & 100.00 & 25.25 & 74.75 & 100.00 \\
1907 & 39.20 & 60.80 & 100.00 & 31.37 & 68.63 & 100.00 \\
1908 & 35.47 & 63.53 & 100.00 & 33.05 & 66.94 & 100.00 \\
\hline
\end{tabular}
Congress.

Source: Moore, Proceedings of the Fourth International Fishery substitute products, existence of large buyers, and quality, in the determination of market prices. Other factors, such as profit and cost considerations, competitor practices, product replacement rate, stability of industry price structure, credit terms, trade discount policies, promotional activities, and government regulations, also Influence prices; however, there is a complete absence of information on such factors for the early years of the sponge industry. Average sponge prices declined by 36 per cent between 1904 and 1907. This could have been the result of an excess in the quantity produced by the prolffic machine diving thod of operation, the result of gathering sponges of inferfor quality, or some other factor not known at present. As was pointed out previously, the supply of sponges depends on many natural factors over which the producers have little or no control. The same is true, although to a lesser extent, for 
the quality of sponges. Spongers rely on luck in locating sponge beds of a given quality, although experience does play a small role. In addition, the quality of any sponge bed hinges on natural factors, such $\mathbf{a s}$ the direction of underwater currents and the existence or sbsence of micro-organisms, which cannot be controlled by man. Since It is a non-perishable commodity, it is possible to hold spong supplies unt1l market conditions become favorable. Because of their limited resources, most f1shermen are unable to exerclse such market power, although some sponge packers have been known to engage in such practices. ' The exercise of market power by a minority of peckers is against the Interests of the jorlty of these flrms; however, at present their cooperative, the Tarpon Springs Sponge Exchange, has no provision to take care of this problem.

\section{Inves tment}

With the exception of a survey conducted in 1932 by Plnellas County, ${ }^{2}$ there are no statistics available on investment in the sponge Plaberies after 1908.

Table 4 indicates investment in the sponge fisheries of Florida for avallable years from 1880 to 2963 . The decline of total dollars invested has not been as spectacular as the decline in the size of the pleet used in sponge flshing, due to the constant decline in the value of the dollar.

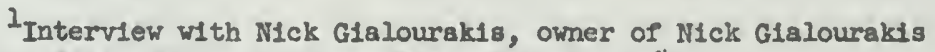
Packing Firm, Tarpon Springs, Fla., May 12, 1964.

${ }^{2}$ Fred K. Sage, "Sponge Industry Sumary Report," Pinellas County, Fls., C. W. A. Project 52-89. (Mimeogrsphed.) 


\section{TABLE 4}

INDEXES OF THE NUMBER OF CRAFT BY METHOD OF OPERATION OF TOMAI BMPLOYMENT AND INVASTMENT IN THE FLORIDA SPONGE INDUSTRY FOR AVAILABLE YEARS, $2880-1963^{\mathrm{B}}$

$$
1905=100
$$

\begin{tabular}{|c|c|c|c|c|}
\hline Year & $\begin{array}{l}\text { Investment in } \\
\text { Current Dollars }\end{array}$ & $\begin{array}{l}\text { Hooking Craft } \\
\text { Index }\end{array}$ & $\begin{array}{l}\text { Diving Craft } \\
\text { Index }\end{array}$ & $\begin{array}{l}\text { Total Bmployment } \\
\text { Index }\end{array}$ \\
\hline 1880 & $\$ 162,050$ & -. & .. & -. \\
\hline 1900 & 494,866 & •. & •. & - \\
\hline 1903 & 502,669 & .. & $\bullet$ & -. \\
\hline 1904 & 417,591 & - & $\because$ & ․ \\
\hline 1905 & 459,871 & 100 & 100 & 100.00 \\
\hline 1906 & 447,033 & . & . & - \\
\hline 1907 & 479,054 & $\because$ & $\cdots$ & - \\
\hline 1908 & 555,267 & 68 & 1025 & 164.00 \\
\hline 1932 & 270,000 & $\ddot{\sim}$ & $\ddot{0}$ & $\ddot{0}$ \\
\hline 1937 & . & 76 & 600 & 67.00 \\
\hline 1940 & -. & 52 & 558 & 51.00 \\
\hline 1950 & . & 8 & 50 & .60 \\
\hline 1955 & -. & 12 & 117 & 1.10 \\
\hline 1960 & - & 7 & 100 & .90 \\
\hline 1961 & .. & 25 & 100 & 1.60 \\
\hline 1962 & 411,300 & 24 & 150 & 1.08 \\
\hline 1963 & 325,000 & 22 & 108 & . \\
\hline
\end{tabular}

Source : 1880, 1900, 1903-1908 from Noore, Proceedings of the Fourth International Fishery Congress. 1932 from "A Survey of the Sponge Industry," F. E. R. A. Project No. 52-7-31. (Typewritten.) 1962-1963 based on estimates by the President of the Tarpon Springs Sponge Exchange and boat captains. Index numbers based on Talile 8 and Table 15.

In 1932 there were 51 diving craft and 15 booking craft in the sponge fisherles of Florlda. Each diving craft had a market value of $\$ 5,000$ and each hooking craft a market value of $\$ 500$. In 1962 the flisheries had 18 diving craft and 81 hooking craft. Each of the former had a market value of $\$ 17,000$, and each of the latter was valued at $\$ 1,300$. By 1963 the number of diving craft had declined to 13 and that of hooking craft to 80 with no change in estimated market values from 1962. 
Between the years 1880 and 1903 lnvestment in the sponge fisheries increased steadily and became relatively stable between 1903 and 1908. In 1908, the level of investment in the sponge fisheries reached 1ts peak, probably because of a tremendous increase in the size of the diving fleet during that year. Nlthough statistics concerning investment in the industry are scant, from avallable information one can deduce that the level of investment in the sponge fisherfes declined rapidly during the depression of the 1930's and has been rather unstable since 1952. Table 4 dramatizes this situation by the use of index numbers. Taking the year 1905 as a base year, total physical investment in the hooking fleet in 1963, messured in numbers of craft, had declined by 78 per cent. By using the same base year one gets an index of 108 for the diving fleet, meaning that between the years 1905 and 1963 the diving fleet increased by 8 per cent. However, one should not overlook the fact that 1905 was the year in which machine diving was first introduced to the shores of the western Atlantic and that, taking 1905 as a base, the boat-number Index stood at 1025 in 1908, only three years later (again see Table 4).

\section{Costs}

W1th the exception of the Pinellas County survey made in 1934, there are no statistics avallable on operating costs in the sponge fisheries. This survey glves the operating costs of 49 diving craft for the first six months of 1934. The total operating costs for the fleet are shown to be $\$ 104,136$ with an average f1gure of $\$ 2,123$ per boat. 
TABLE 5

SEMI-ANWUAL OPERATING EXPENSES OF 49 DIVING CRAFT

IN PINELILAS COUNIY, JAMUARY I - JUNE 30, 1934

Item

Amount

$\$ 35,731.00$

41,512.89

$6,050.00$

$6,145.00$

$11,052.26$

$3,644.85$

$\$ 104,136.00$

Total

\section{Total}

Average

Per Craft

Exchange Fees

Source: Plnellas County, Fla., F. E. R. A. Project Ho. 52-F2-31.

If it is assumed that the next six months were similar to the preceding $61 x$ months, the annual operating expenses were $\$ 208,272$ for the lleet, and each of the 49 boats had an average of $\$ 4,246$ as operating costs. This figure is only $\$ 88$ lower than the present average operating expenses of each diving craft. The market value of a bost more than tripled between 1934 and 1963 , and in view of this fact and the substantial increase in the average price level between 2934 and the present, the validity of the $\$ 4,246$ figure looks very questionable, although one must always bear in mind that averages, unless adequately explained, are full of pltfalls. The per-craft operating expenses flgure for 1934 was reached by dividing total operating expenses by the number of boats in operation at that part1cular time. In 1934, 
the fleet contained large boats, each with $81 x$ or more divers who harvested sponges in depths up to 150 feet. ${ }^{1}$ By contrast, all craft In the present fleet are considerably smaller and have a maximum of two divers who never go below 60 feet. $^{2}$ It 18 obvious that such large boats would have had substantially higher operating expenses. The existence of such extreme values might have influenced averages, glving the above-mentioned unrealistic picture of costs. To be sure, the above treatment of costs is based on fragmentary information and may be only of historical value; however, historical data are frequently important in comprehending current events. By relating past and present information, it is of ten possible to give meaning to present occurrences and to understand the forces that brought such phenomens into existence.

\section{Employment}

According to a survey of Florida fisheries made by Professor Carter C. Osterbind in 1953, the number of Plshermen in Florida has not tended to Increase over the past half century but has fluctuated around the number employed in the industry at the beginning of the certury (see Table 6). Table 7 indicates total employment and employmert by method of operation in the sponge f1sherles for the years 1895 to 1908. While fishery employmeat has remained relatively stable in Florida, employment in the sponge fisheries has declined precipitously. Between 1895 and 1905 employment in the sponge f1sherles increased by

Interview w1th John Samarkos, Captain of the diving craft"Eleni," Tarpon Springs, Fla., May 11, 1964.

${ }^{2}$ Ibid. 
TABLE 6

FISHERMEN EMPLOYED IN COMMERCIAL FISHERIES IN FLORIDA, SEIECTED YEARS, 1890-1962

Year

Number of F1shermen

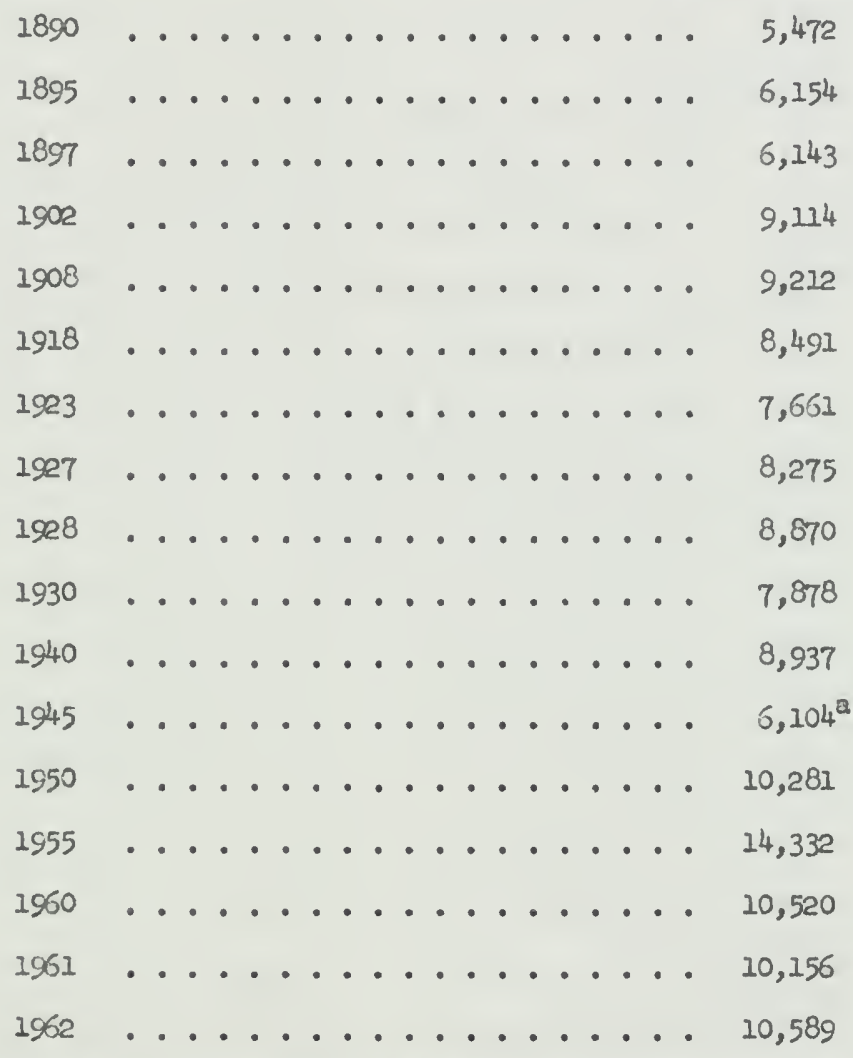

Source: 1890-1950 from Osterbind. 1955-1962 from U. S., F1sh and Hildlife Service, U. S. Flshery Statistics.

arst Coast only. 
TABLE 7

NURBER OF CRAFT AND EMUPOYMENT BY MEIHOD OF OPERATION, 1895, 1900, 1903-1908

\begin{tabular}{|c|c|c|c|c|c|}
\hline \multirow[b]{2}{*}{ Year } & \multicolumn{2}{|c|}{ Hook1ng } & \multicolumn{2}{|c|}{$\mathrm{D} \operatorname{1v} \ln B$} & \multirow{2}{*}{$\begin{array}{c}\text { Total } \\
\text { Employment }\end{array}$} \\
\hline & Craft & F1shermen & Craft & F1shermen & \\
\hline 1895 & 282 & 1,419 & .. & -. & 1,419 \\
\hline 1900 & 384 & 2,113 & - & $\cdots$ & 2,113 \\
\hline 1903 & 383 & 2,085 & -. & -. & 2,085 \\
\hline 1904 & 338 & 1,777 & $\cdots$ & $\cdots$ & 1,777 \\
\hline 1905 & 337 & 1,743 & 12 & 166 & 1,909 \\
\hline 1906 & 244 & 1,272 & 69 & 942 & 2,214 \\
\hline 1907 & 255 & 999 & 78 & 1,089 & 2,088 \\
\hline 1908 & 228 & 978 & 123 & 1,342 & 2,320 \\
\hline
\end{tabular}

Source : 1895 from U. S., Congress, The Fish and Fisheries of the Coastal Waters of Florida. 1900 from cobb. 1903-1908 from Moore, proceedings of the Fourth International Flahery Congress.

34 per cent. Sponge fishery employment reached a peak of 2,320 only three years later in 1908. Although no employment statistics are avallable after 1908, by 1937 employment in the sponge f18herles had declined by one-third as compared to 1ts 1905 level. Twenty-five years later, in 1962, sponge f1shery employment had declined by almost 99 per cent as compared to employment figures in 1905.

From F1gure 4 one can see that employment in hooking started its decline in 1905 with the introduction of machine diving. By 1907, employment in the diving rleet exceeded employment in hooking, and this situation was not reversed until 1950. 


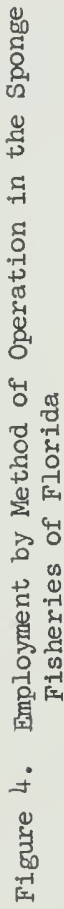

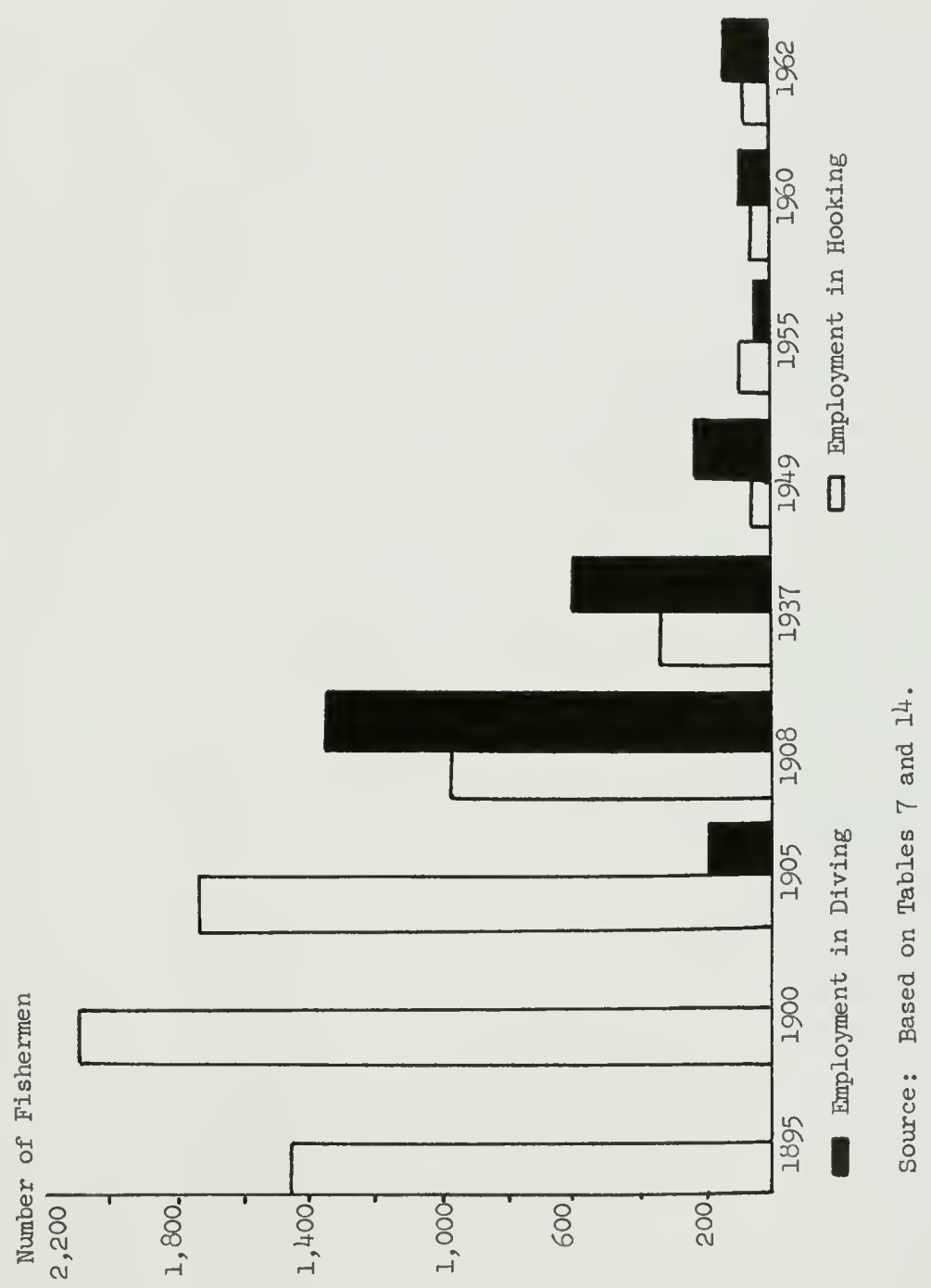


Other things, such as working conditions, esse of entrance and training, opportunities for advancement, and degree of occupational hazard, belng equal, the level of employment in an industry depends upon the level of wages. Wages, on the other hand, depend on the level of productivity, since a higher productivity indicates ability to pay higher wages. ${ }^{1}$ This condition, however, may not materialize. Labor productivity in the sponge fisheries can be measured in terms of the value of average catch per fisherman. The value of average catch per fisherman is derived by dividing total landings by the total number of flshermen employed, snd it depends on two factors: (1) the welght and quality of the landed species and (2) the pricet price that such specles w11I. command.

A comparison of Table 8 with Table 9 shows that the value of average catch per Ilsherman from the very beginning was considerably higher in machine diving. This was so because diving craft not only landed more sponges per enterprise unit but also were able to market their product at higher prices per pound. The columns showing the average price per pound of sponges in Table 8 and Table 9 show this relationship to be true for every year. This higher productivity, coupled with better earnings in machine diving, appears to have caused employment to decline in hooking operations. Also, the introduction of machine diving had a secondary adverse effect on employment in the sponge fisheries. One might say that machine diving, in addition to being more productive, was also a labor-saving method of operation. L1ke any other capital intensive method of production, machlne diving

$1_{\text {Abraham L. G1tlow, Labor Economics and Industrial Relations }}$ (Homewood, IIl.: Richard D. Irwin, 1957), p. 424. 
TABLE 8

AVERAGE CATCB PER HOOKING CRAIT, $1895,1900,1903-1908$

\begin{tabular}{lcccc} 
Year & $\begin{array}{c}\text { Catch Per } \\
\text { Craft 1n } \\
\text { Pounds }\end{array}$ & $\begin{array}{c}\text { Value of } \\
\text { Average Catch } \\
\text { Per Craft } \\
\text { 1n Dollars }\end{array}$ & $\begin{array}{c}\text { Value of } \\
\text { Average Catch } \\
\text { Per Fisherman } \\
\text { In Dollars }\end{array}$ & $\begin{array}{c}\text { Average } \\
\text { Price } \\
\text { Per Pound } \\
\text { 1n Dollars }\end{array}$ \\
\hline 1895 & 1,805 & 1,379 & 272 & 1.26 \\
1900 & 823 & 1,478 & 269 & 1.80 \\
1903 & 987 & 1,168 & 215 & 1.18 \\
1904 & 853 & 1,213 & 212 & 1.29 \\
1905 & 1,054 & 1,412 & 273 & 1.34 \\
1906 & 781 & 885 & 170 & 1.13 \\
1907 & 1,008 & 735 & 180 & .70 \\
1908 & 1,023 & 796 & 186 & .78 \\
\hline
\end{tabular}

Source : 1895 from U. S., Congress, The F1sh and F1sherles of the Coastal Waters of Florida. 1900 from Cobb. 1903-1908 from Noore, Proceedings of the Fourth International Flahery Congress.

tends to use less labor and more capital. Th1s fact, later coupled with shrinking markets because of substitute competition from synthetics and diseases in the sponge beds, resulted in a preclpitous decline in total employment in the sponge fisheries as indicated in Table 4. As was mentioned previously the value of average catch per flsherman concept is by no means an indication of the actual wages recelved by fishermen. It is only a measure of labor productivity. The actual wages recelved by flshermen depend on many additional factors, such as employer bargalning power, degree of intrs-1ndustry 
TABLE 9

AVERAGE CATCH PER DIVING CRAFT, 1905-1908

\begin{tabular}{lcccc} 
Year & $\begin{array}{c}\text { Catch Per } \\
\text { Craft 1n } \\
\text { Pounds }\end{array}$ & $\begin{array}{c}\text { Value of } \\
\text { Perage Catch } \\
\text { in Dollars }\end{array}$ & $\begin{array}{c}\text { Value of } \\
\text { Average Catch } \\
\text { Per Fishernan } \\
\text { In Dollars }\end{array}$ & $\begin{array}{c}\text { Average } \\
\text { Price } \\
\text { Per Found } \\
\text { in Dollars }\end{array}$ \\
\hline 1905 & 833 & 3,980 & 288 & 4.78 \\
1906 & 5,803 & 9,257 & 678 & 1.60 \\
1907 & 5,113 & 5,031 & 360 & .98 \\
1908 & 3,164 & 2,987 & 274 & .94 \\
\hline
\end{tabular}
Congress.

Source: Moore, Proceedings of the Fourth International Flahery competition, and fishermen's ability to find employment in other fisheries or flelds of employment.

There are no actual earnings figures avallable for fishermen in the sponge industry, with the exception of the PInellas County survey. According to this report, earnings in the sponge flsherfes for the first six months of 1934 were as follows:

$\begin{array}{lr}\text { Average earnings for divers } & \$ 512.50 \\ \text { Average earnings for engineers } & 382.00 \\ \text { Average earnings for life line tenders } & 300.00 \\ \text { Average earnings for crev members } & 215.00\end{array}$

A more detalled description of earnings will be given in the next chapter, although at this stage it might be pertinent to mention that labor remuneration in the sponge fisheries is not a set amount of wages but consists of a sharing system after the subtraction of certain costs from total recelpts. 
The Period from 1937 to 1954

The yexrs following 1937 were full of unprecedented disturbances for the Flor1da sponge industry. Factors, such as the 1937 disease of the sponge beds, World War II, competition frcm synthet1cs, the disease of 1947 (the red tide), and an acute shortage of labor, caused the sponge industry to undergo drastic changes. The effects of these events by themselves and through interaction with each other appear to have shaped the future of the sponge industry in an unalterable manner.

\section{Production}

The year 1937 marks the beginning of a secular decline in the sponge f1sheries, for 1t was in 1937 that a destructive marine microorganism inveded all the known sponge beds in the westem Atlantic, resulting in a drastic decline in sponge landings. The velvet sponges were hardest hit by this disease and were almost completely wiped out. Despite this decline in the welght of landings, however, the number of hooking craft between 1937 and 1939 increased from 256 to 301 and the number of diving craft from 72 to 89 (see Table 14).

The decline in the productivity of the sponge beds, coupled with an increased number of craft, resulted in lower landings per craft. For example, between 1937 and 1940 landings per diving craft declined from 6,551 pounds to 3,027 pounds. In the meantime, the value of average landings per diving craft declined only slightly between 1937 and 1940 , from $\$ 13,259$ to $\$ 11,445$ because of higher prices recelved (see Trbles 15 and 16). 
As can be seen in Figure 5 the decline in landings was accompanied by a tremendous increase in the value of landings. Th1s increase was caused primarily by the entrance of the Federal Government in the market as an active sponge buyer. During the war years the United States Government bought practically all the sponges landed. ${ }^{2}$ The existence of such a large-scale buyer caused sponge prices to skyrocket within a very short period of time. For example, average sponge prices at the producers' level rose from \$2.49 per pound in 1939 to $\$ 15.99$ a pound in 1945 (see Table 10). It was such price increases that lured additional Investment into the sponge fisheries at a time when the productivity of the sponge beds was declining because of a marine disease. Although no officlal statistics are avallable on the number of craft in the sponge fisheries during the war years, in conversations with flshermen in Tarpon Springs the author was told that more than 90 diving craft were in operation during World War II.

The interaction of the 1937 disease and forld War II set the stage for the f1nal collapse which took place in 1949. There were two reasons for the collapse. First, heavy government purchasing during the war years dislocated many established trade relationshlps. Unable to compete with the government many natural sponge users had to use substitute products during the war years when sponges were Bcarce. It was 1mpossible to recapture such users after the war, and the majority of them, including the American housewife, were lost permanently to synthetics. ${ }^{2}$ second, an increase in the number of

I"Sponges for War," Business Week, April 10, 1943, p. 30.

IInterview with Edward Riley, President of American Sponge and Chamois Co., Iong Irland C1ty, N. Y., November 19, 1964. 


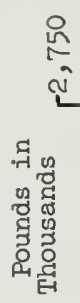

\&

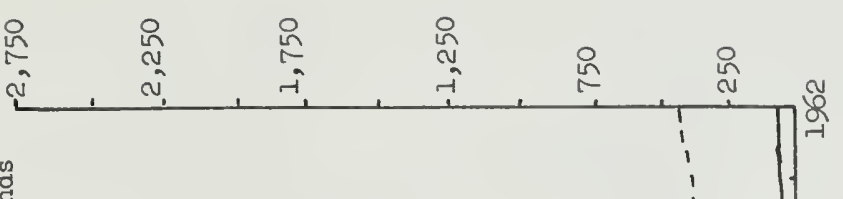

?

站

I

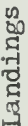

떵

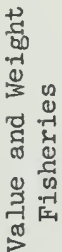

เ่

ट्ञ त्व

I

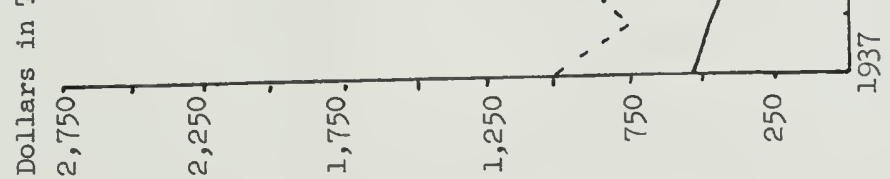

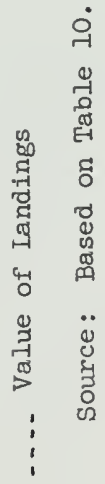




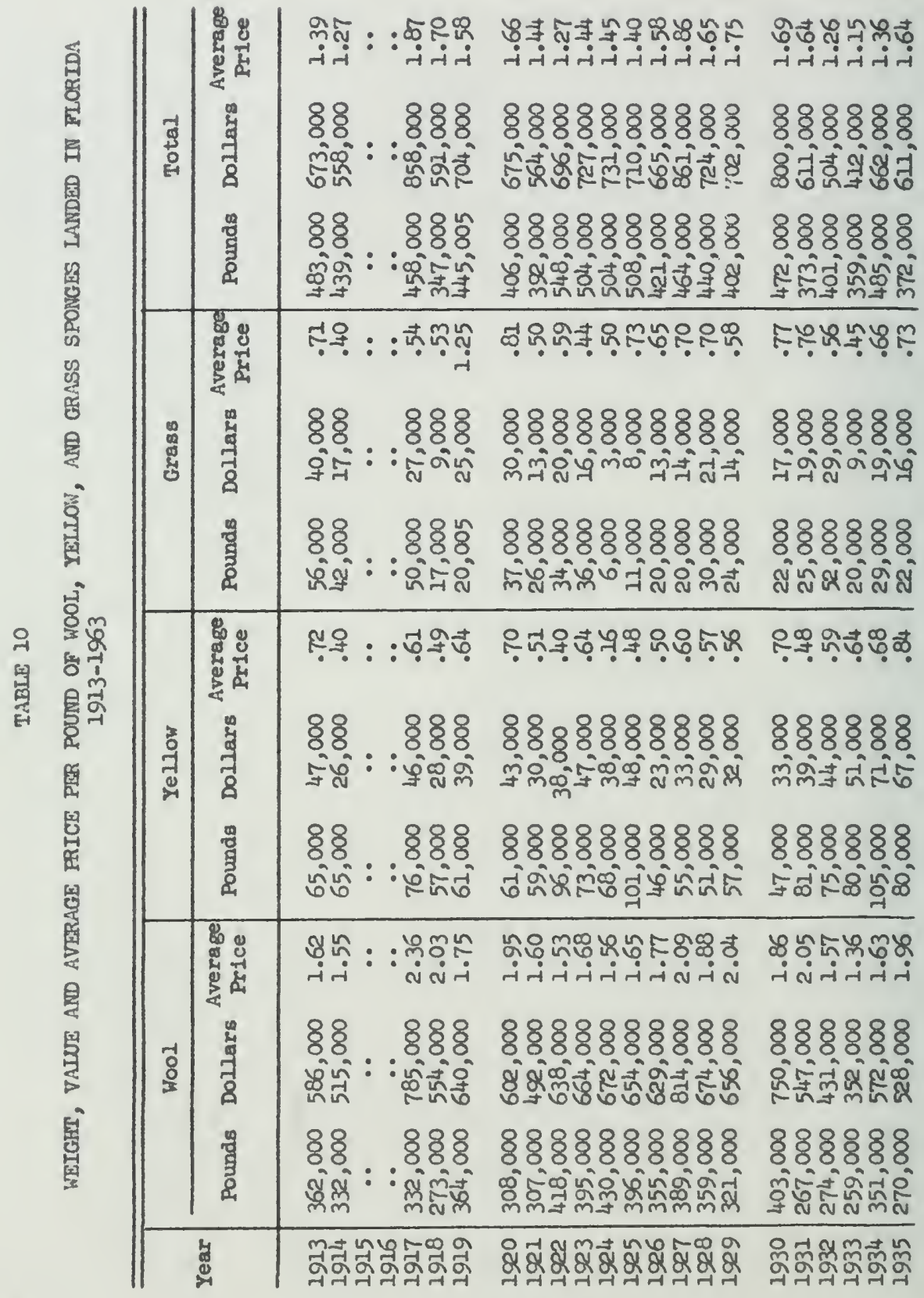




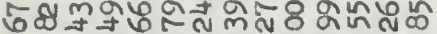

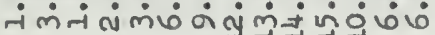
888888888888 ผू

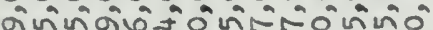

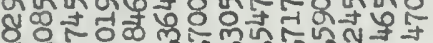
윰ำ

888888888888 చే

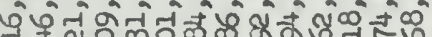
जु जै

जn . . - min்

\#

0.

8888888888

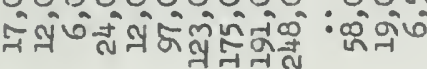

$8 \%$ m
क्ष

8888888888 8न

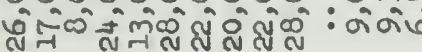

888888888888 ஸ்.

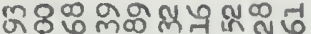

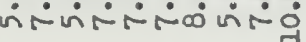

8 in 6 a 8 w un

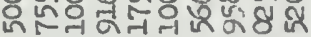

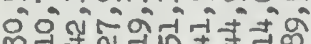

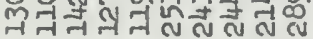

888888883888 \% 888 엉워

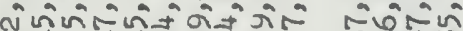
लूलन

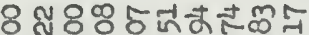

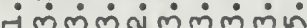

ㄱํㅇํㅇํำ लंம்

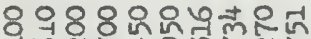

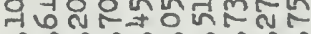

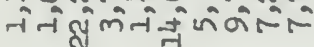

ํํㅇ워용 -1 बin

$888888898898 \mathrm{Na}$ 的和8

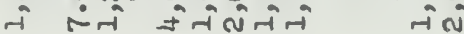

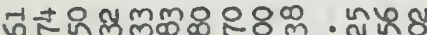
-i mं

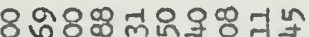
. -imмंmmiñ

ㄸำ mंmंन्ं

$\ln 9 \%$

กิ जे $\neq+\infty$

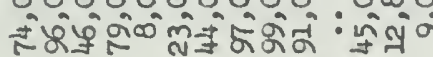

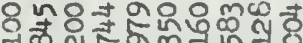
- -10 miñ⿻

8888888888 ज约 m8न

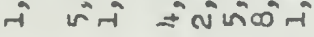
888888888888

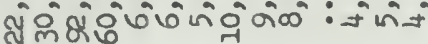

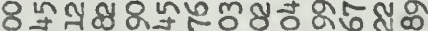
लं

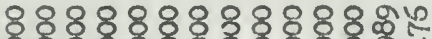
$888888888888 \%$ क

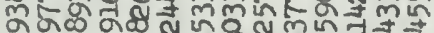

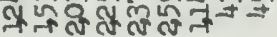
888888888898 용 ర08080888080

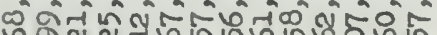

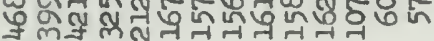

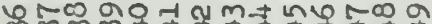
ผ

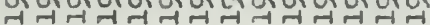

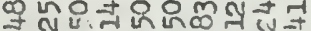
งก: மீ人ம்

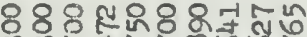

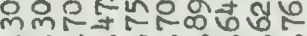
किं

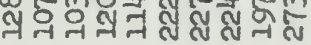
8838888888

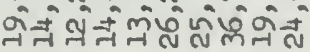

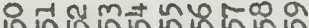
К

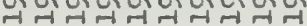

8888 नोली ने

단 ம 0 ○ं

$85 \mathrm{gm}$ 내o i - 6 6 ल लm

$889 \mathrm{~m}$ 8 소요 जोंजेmmat

다요 $888 \%$ त्नलत्न

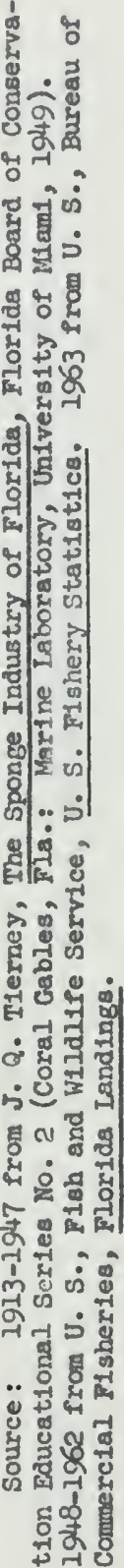



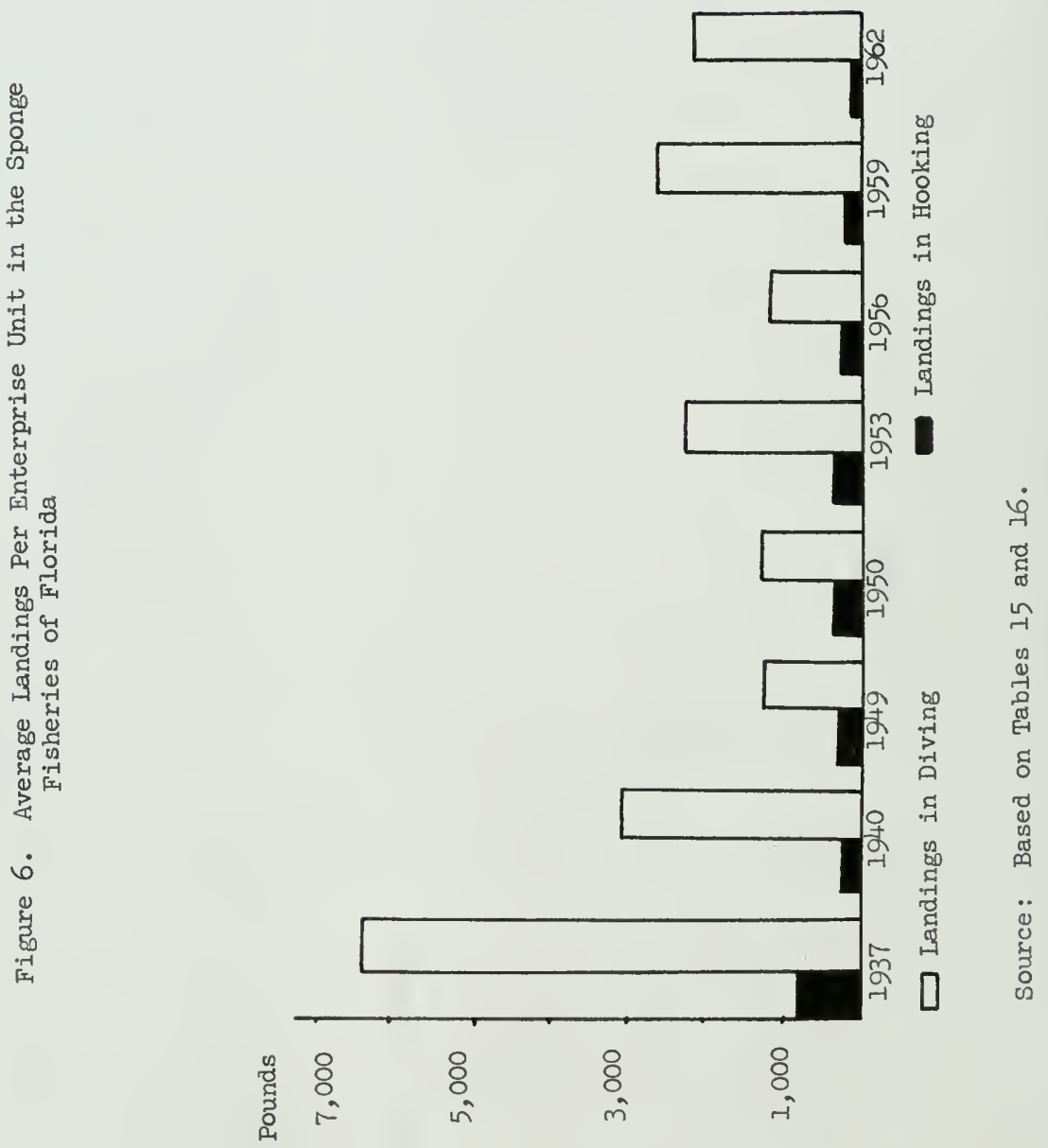
craft at a time when sponge beds were hit by an epidemic meant that the beds were being flshed to the point of depletion. Figure 6 indicates how rapidly catch per craft declined after 1937. This should have aroused some concern about conservation of the sponge beds, but instead higher prices caused prectices which led to an almost complete exhaustion of the beds. 1

After the exit of the United States Government from the market as an active buyer of sponges, average per pound prices fell from the $\$ 15.99$ peak in 1946 to $\$ 6.26$ in 1948. Average catch per diving craft stood at 1,458 pounds in 1949. This decline in catch per eraft along with greatly weakened prices caused the number of diving craft to be reduced to 40 in 1949, a decline of almost 50 per cent in three years. The final blow to the Industry came when the already exhausted sponge beds were struck by another disease in 1949.2

After having reached a peak of $\$ 2,715,000$ in 1945 (again see Table 10), sponge landings dropped to $\$ 110,755$ by 1951 , a per1od of six years. The diving fleet, which had consisted of over 90 craft during the war, contained only two outfits in 1952 (again see Table 14). This fluctuation in the number of craft can be explained in terms of opportunity costs. In economics the concept of opportunity cost denotes the most fevorable price that can be comanded by a factor of production, which thus tends to become the minimum cost at which that factor can be had by any user. 3 Although sponge outfits are a

$$
\begin{aligned}
& \text { Istorr, p. } 51 . \\
& \text { 2ro1d., p. } 48 .
\end{aligned}
$$

3 Harold S. Sloan and Arnold J. Zurcher, A Dictionary of Economica (New York: Barnes \& Noble, 1958), p. 234. 


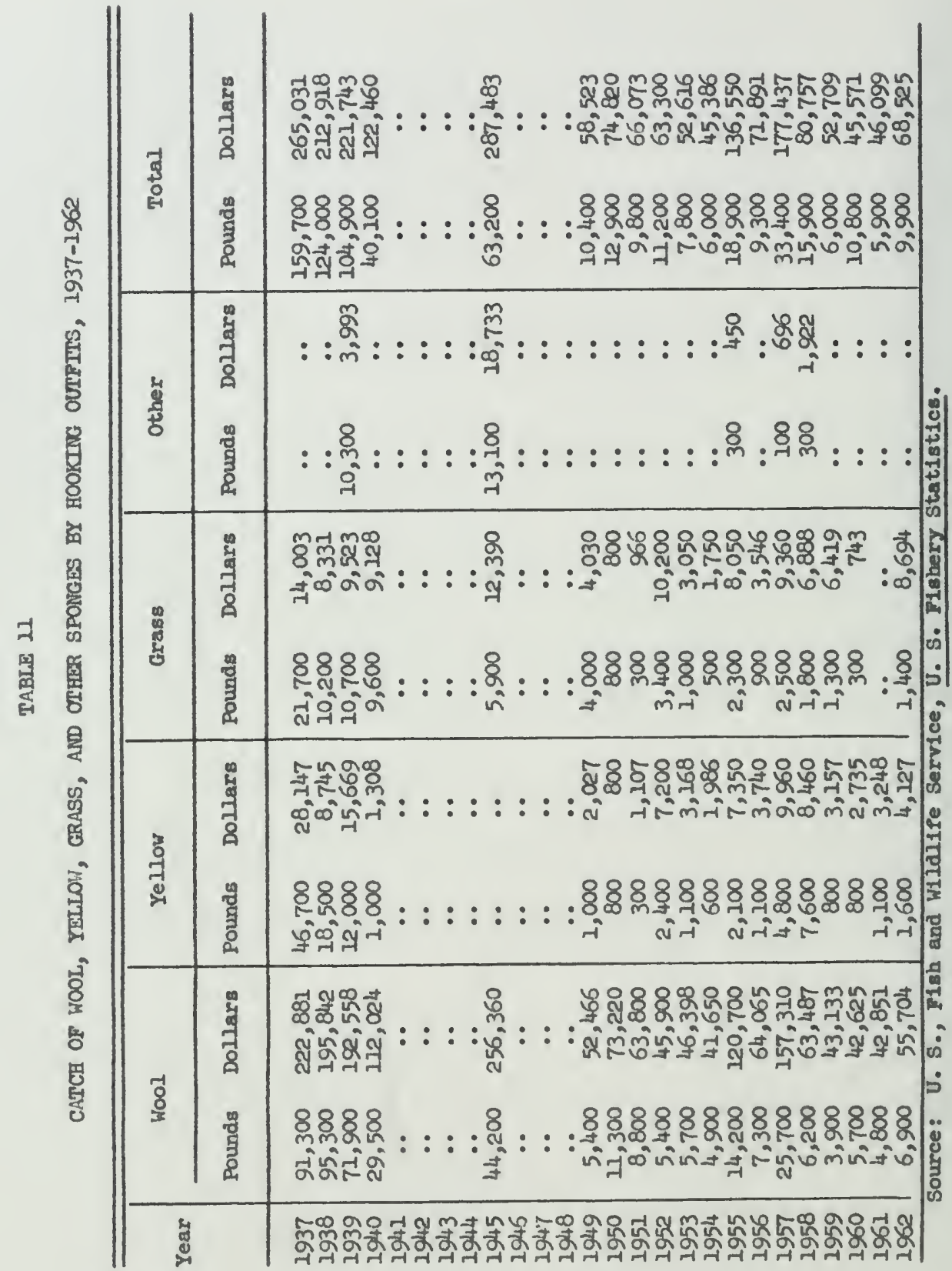




\begin{tabular}{|c|c|c|}
\hline 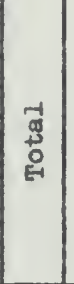 & "̆ & 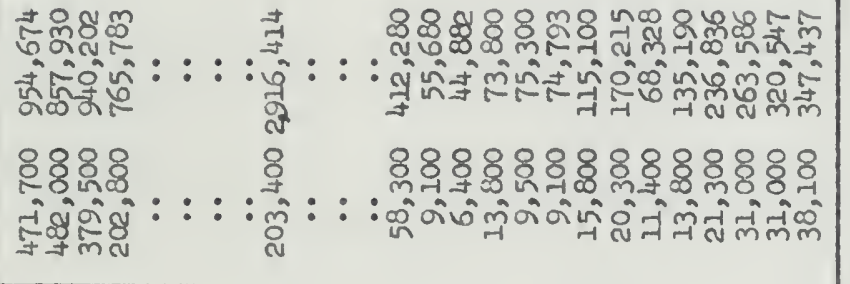 \\
\hline 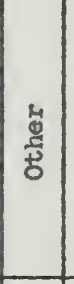 & 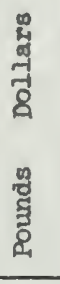 & 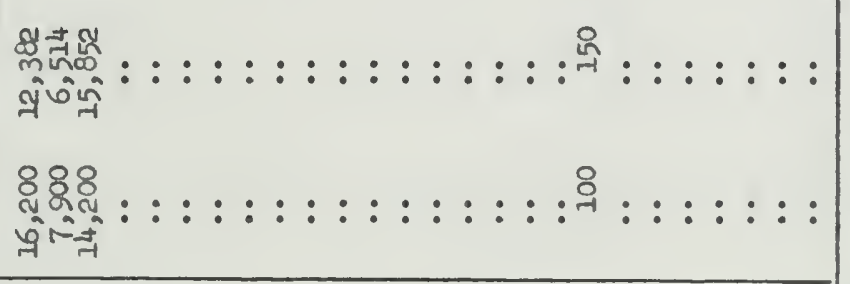 \\
\hline 总 & 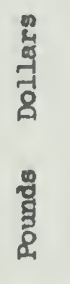 & 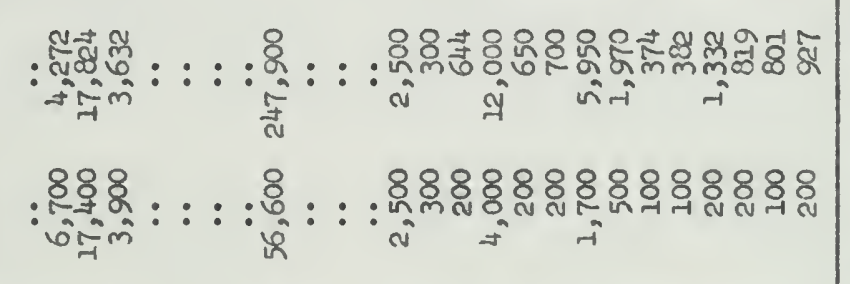 \\
\hline & 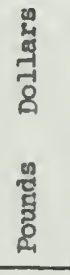 & 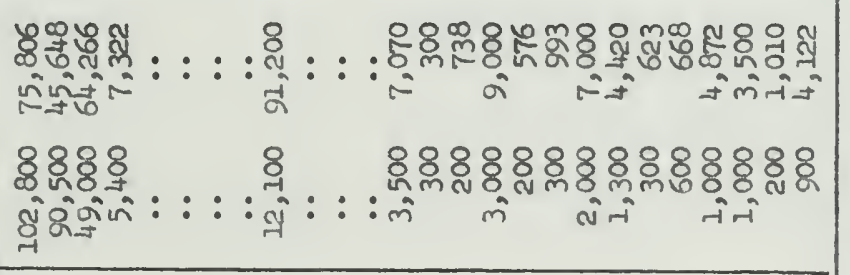 \\
\hline$\frac{\overrightarrow{0}}{\vec{g}}$ & 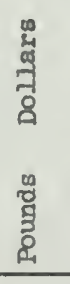 & 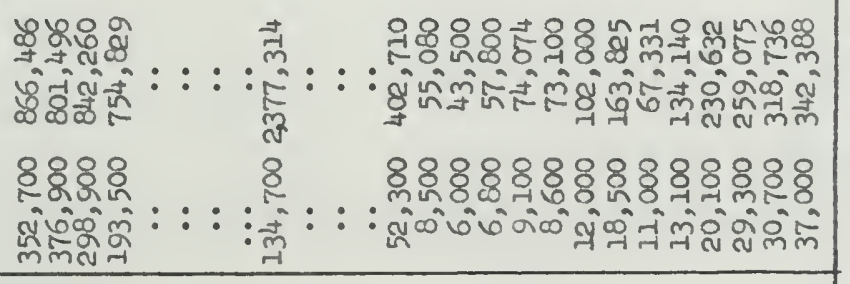 \\
\hline & & \\
\hline
\end{tabular}




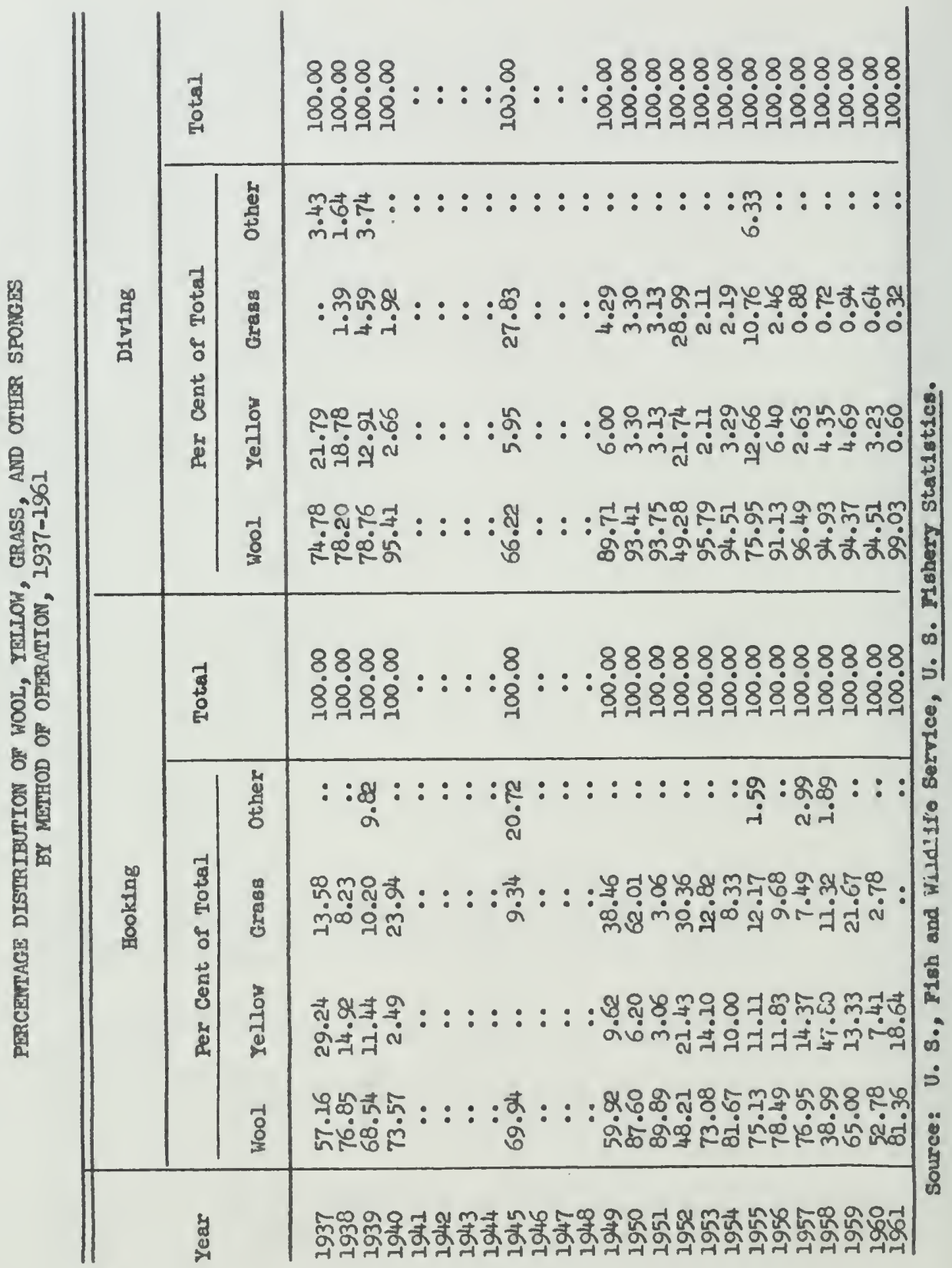


speclalized type of flshing craft, when ylelds in sponging fall too low It becomes necessary for some outfits to convert to other types of f1shing. For example, after 1952 many diving craft converted to shrimp boats. ${ }^{1}$ This exodus of outfits came to an end when the remaining craft could earn a satisfactory return, that is, when the earnings in the sponge flisherles were equal to earnings in the next easlest accessible type of fishery.

The reduction of the fleet also had a beneficial effect on the productivity of sponge beds; with fewer flshing outfits in existence sponge beds could be flshed less extensively. This reduction in flshing effort gave the almost depleted sponge beds an opportunity to recuperate. As the sponge beds recuperated catch per craft improved. Assuming that there is no change in the price level, increasing catch per craft means higher earning6. Higher earnings in turn attract more investment into the flsherles, and this condition continues until the last craft attracted to the sponge fisheries eams an amount equal to what 1t would have earned in some other type of flshing activity. A practical application of the afore-mentioned relationship can be observed in the anticipated earnings behavior of the shrimp fisheries during 1953 and 1957. In the shrimp fisherles these years were charscterlzed by very high landings per craft, and each of these years was followed by a large increase in the slze of the flshing fleet in the shrimp fisherles. ${ }^{2}$ of course, such conditions will be met only under the postulate of labor and capital mobility. To the extent that

IInterview w1th Louls Sm1tzes, May, 1964.

${ }^{2}$ Carter C. Osterb1nd and Robert A. Pant1er, Economic Study of the Shrimp Industry in the Gulf and South Atlantic States (Gainesville, Fla.: Bureau of Economic \& Business Research, University of Florida, 1965) po 23. 
factors of production are immobile, the production of a particular economic good will not respond readily to changes in the level of earnings. I

The degree of mobility is not the same for hooking and machine diving. As can be seen in Flgure 7 hooking crapt enter into and exit from sponge flshing more readily than diving craft. This is due to the fact that diving, as compared to hooking, is a more specialized operation. It takes more effort to convert diving outfits into other types of flshing boats, whereas hooking outf1ts can be easily adapted to other types of flshing. Also, unlike hooking, machine diving is a highly skilled operation, and such skills cannot be easily transferred to other types of flshing at the same level of earnings. In other words, diving craft personnel be as moblle as other flshermen in obtalning less skilled jobs, but they have less horizontel mobility since no other type of flshing operation has use for submarine divers.

\section{Investment}

Based on current market values expert opinion has estimated 1963 investment in the sponge 11sherles to be approximately $\$ 325,000$ (again see Table 4). This figure is restricted to investment in the fleet alone and doss not include money 1rvested in shore fac1litles, such as the Tarpon Springs Sponge Bxchange, or other auxillary activities, such as investment in the packing establishments.

Figure 7 shows fluctuations of physical lnvestment messured in number of craft in the sponge fishery. It can be observed from the chart that the number of hooking outfits has rluctuated more widely

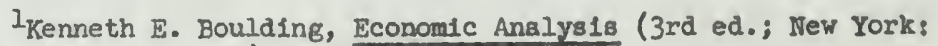
Harper \& Bros., 1955), p. $2 \overline{19}$ 

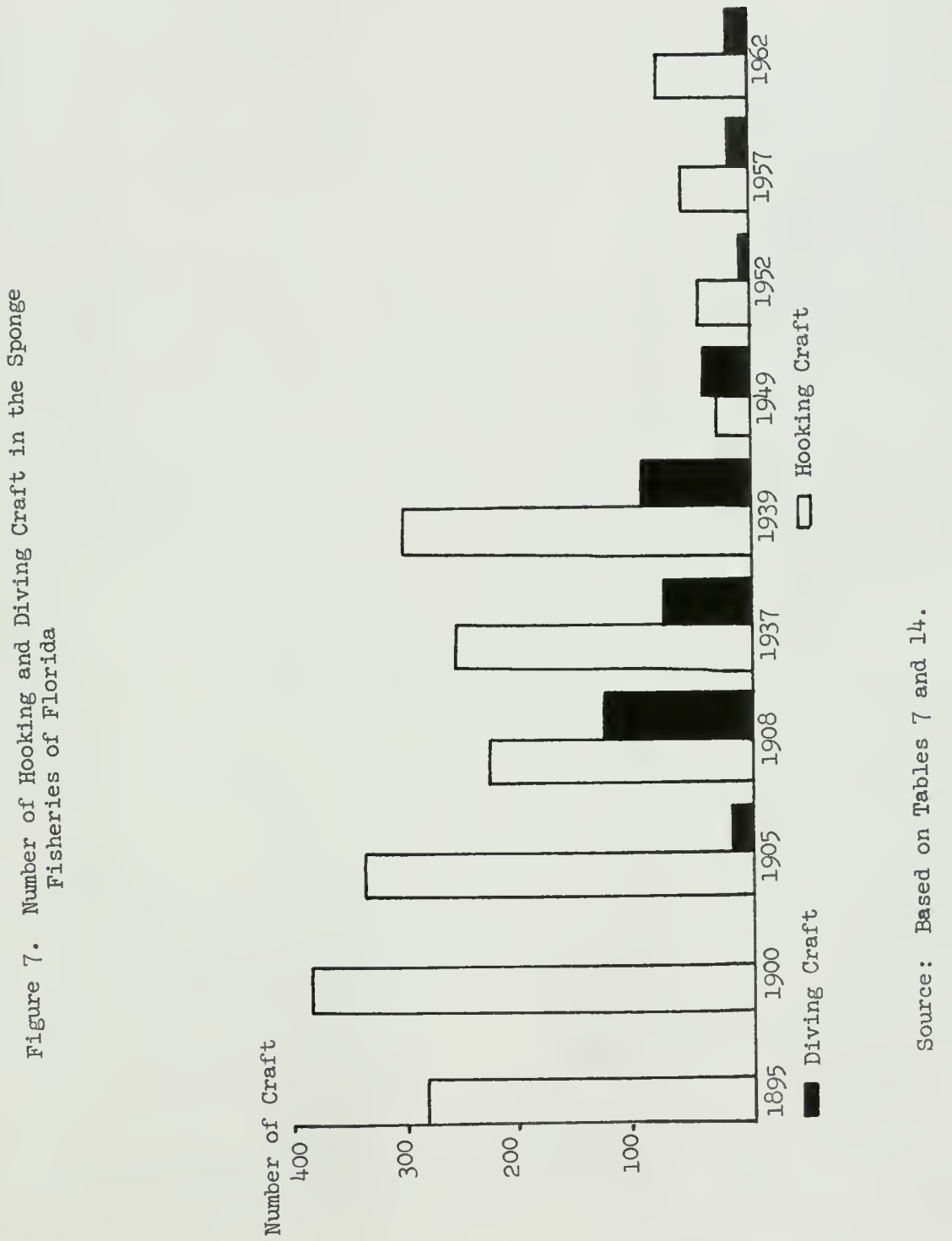
TABLE 14

NUMBER OF CRAFT AND EMPLONMENT BY METHOD OF OPERATION, 1937-1963

\begin{tabular}{|c|c|c|c|c|c|c|c|c|c|}
\hline \multirow{3}{*}{ Year } & \multicolumn{4}{|c|}{ Hooking } & \multicolumn{4}{|c|}{ Diving } & \multirow{3}{*}{$\begin{array}{l}\text { Total } \\
\text { Employ- } \\
\text { ment }\end{array}$} \\
\hline & \multirow{2}{*}{ prapt } & \multicolumn{3}{|c|}{ Flohermen } & \multirow{2}{*}{ Craft } & \multicolumn{3}{|c|}{ Fishermen } & \\
\hline & & Regular & Casual & Total & & Regular & Casual & Total & \\
\hline $\begin{array}{l}1937 \\
1938 \\
1939 \\
1940 \\
1941 \\
1942 \\
1943 \\
1944 \\
1945 \\
1946 \\
1947 \\
1948 \\
1949 \\
1950 \\
1951 \\
1952 \\
1953 \\
1954 \\
1955 \\
1956 \\
1957 \\
1958 \\
1959 \\
1960 \\
1961 \\
1962 \\
1963\end{array}$ & 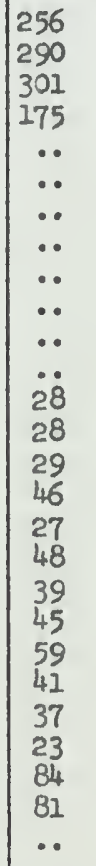 & $\begin{array}{r}380 \\
410 \\
489 \\
233 \\
.0 \\
.0 \\
\therefore \\
\therefore \\
\therefore \\
.0 \\
.0 \\
57 \\
59 \\
60 \\
96 \\
75 \\
67 \\
44 \\
57 \\
63 \\
67 \\
73 \\
58 \\
67 \\
69 \\
. .\end{array}$ & 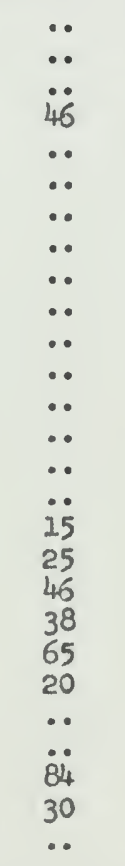 & $\begin{array}{r}380 \\
410 \\
489 \\
279 \\
\cdots \\
\cdots \\
\cdots \\
\cdots \\
\cdots \\
\cdots \\
\cdots \\
10 \\
57 \\
59 \\
60 \\
96 \\
90 \\
92 \\
90 \\
95 \\
128 \\
87 \\
73 \\
58 \\
151 \\
99 \\
0\end{array}$ & $\begin{array}{r}72 \\
72 \\
89 \\
67 \\
0 . \\
\cdots \\
\cdots \\
\cdots \\
0 . \\
0 \\
0 \\
40 \\
6 \\
3 \\
2 \\
4 \\
9 \\
14 \\
17 \\
13 \\
10 \\
8 \\
12 \\
12 \\
18 \\
13\end{array}$ & $\begin{array}{r}569 \\
509 \\
634 \\
451 \\
\ldots \\
\ldots \\
\ldots \\
\ldots \\
\ldots \\
. \\
. \\
223 \\
36 \\
12 \\
12 \\
28 \\
54 \\
66 \\
66 \\
42 \\
53 \\
56 \\
60 \\
50 \\
108 \\
78\end{array}$ & 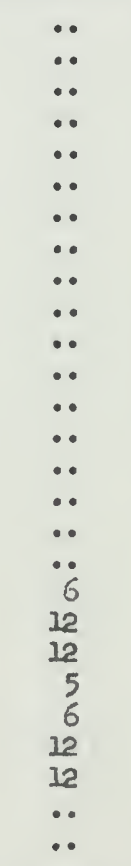 & $\begin{array}{r}569 \\
509 \\
634 \\
451 \\
\ldots \\
\therefore \\
\therefore \\
\therefore \\
\cdots \\
\cdots \\
\therefore \\
223 \\
36 \\
12 \\
12 \\
28 \\
54 \\
72 \\
78 \\
54 \\
58 \\
62 \\
72 \\
72 \\
108 \\
78\end{array}$ & $\begin{array}{r}949 \\
919 \\
1,123 \\
730 \\
0 \\
0 \\
\therefore \\
\therefore \\
\therefore \\
0 \\
28 \\
85 \\
72 \\
108 \\
118 \\
146 \\
162 \\
173 \\
182 \\
145 \\
135 \\
130 \\
223 \\
207 \\
78\end{array}$ \\
\hline
\end{tabular}

Source: U. S., Fish and WIIdIfe Service, U. S. Flshery Statistics. 
than the number of diving outfits. The ressons for this pattern will be explained in the following sect1on. Although diving outfits have always been fewer in number than hooking outf1ts, with the exception of a few years, they have always landed a larger percentage of the total catch (see Table 17). The same table also indicates that for each year the percentage value of landings credited to diving craft has always exceeded their percentage contribution to physical landings, thus showing that throughout history the diving fleet has maintalned Its ab1l1ty to comand better prices for 1 ts products.

As can be seen from Figure 6 productivity per enterprise un1t has always been highest for alving craft. This bas been true without except1on, even for years when the entire diving fleet has landed fewer sponges than the entire hooking fleet. The recent upgurge in the number of hooking craft is not of great signiflcance, since a majorlty of such outfits do their fishing as a sldeline or on a parttime basis. The number of diving craft seems to have stabllized during the last few years, mainly due to a shortage of qualifled divers.

Flgure 8 and Flgure 9 show the relationship between the number of craft (physical investment) and catch per craft for hooking and diving outfits respectively. One can readily deduce that as the number of craft decreases the productivity per enterprise unit tends to $g 0$ up, but this increase in productivity per craft - assuming no drast1c decline in sponge prices - w1ll attrect outflts that had previously left sponging for more lucrative fishing activities. Flgure 10 1Ilustrates the conccpt of stable equilibrium in the sponge flsheries; however, the relationships plctured in Figure 10 will occur 

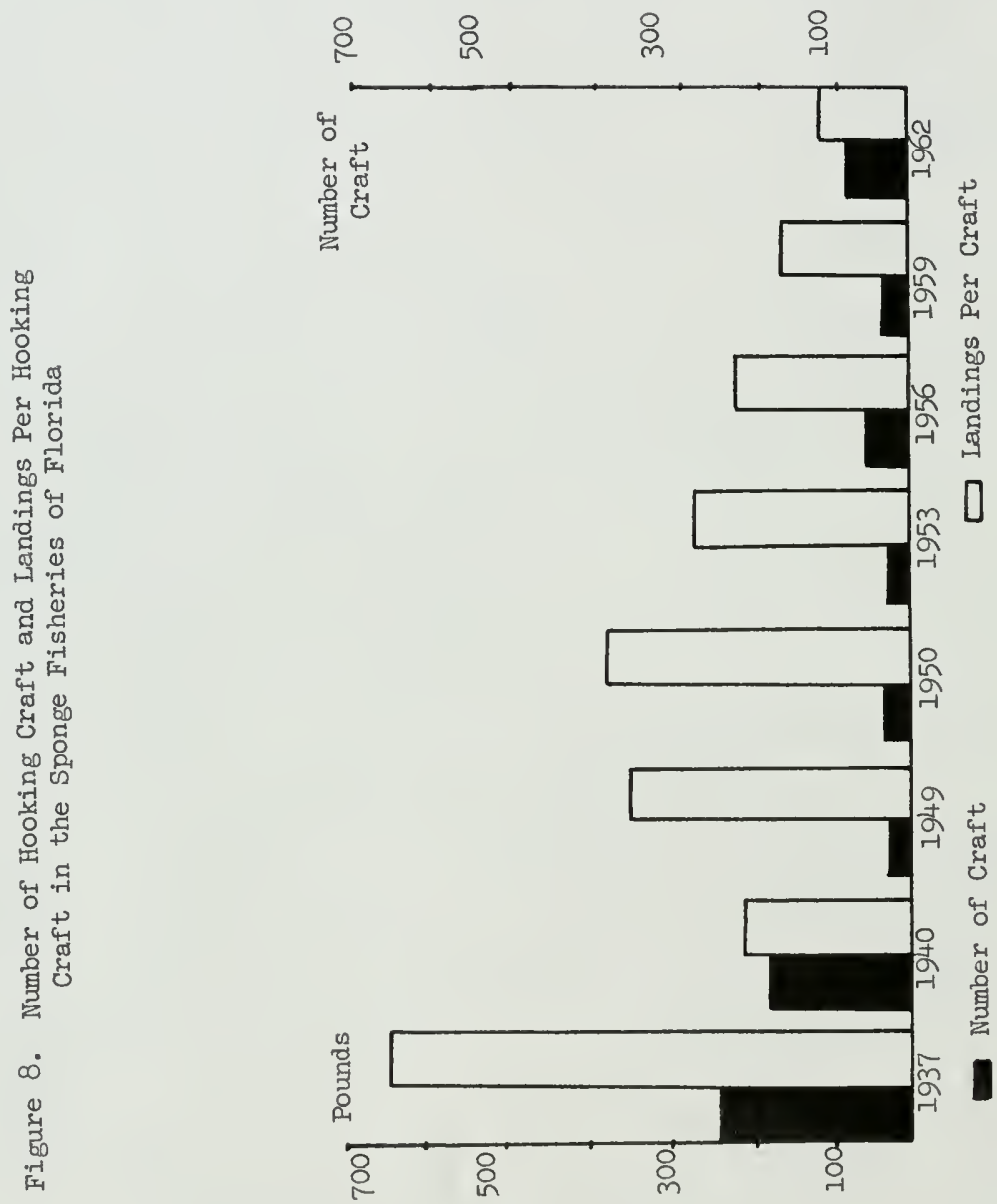

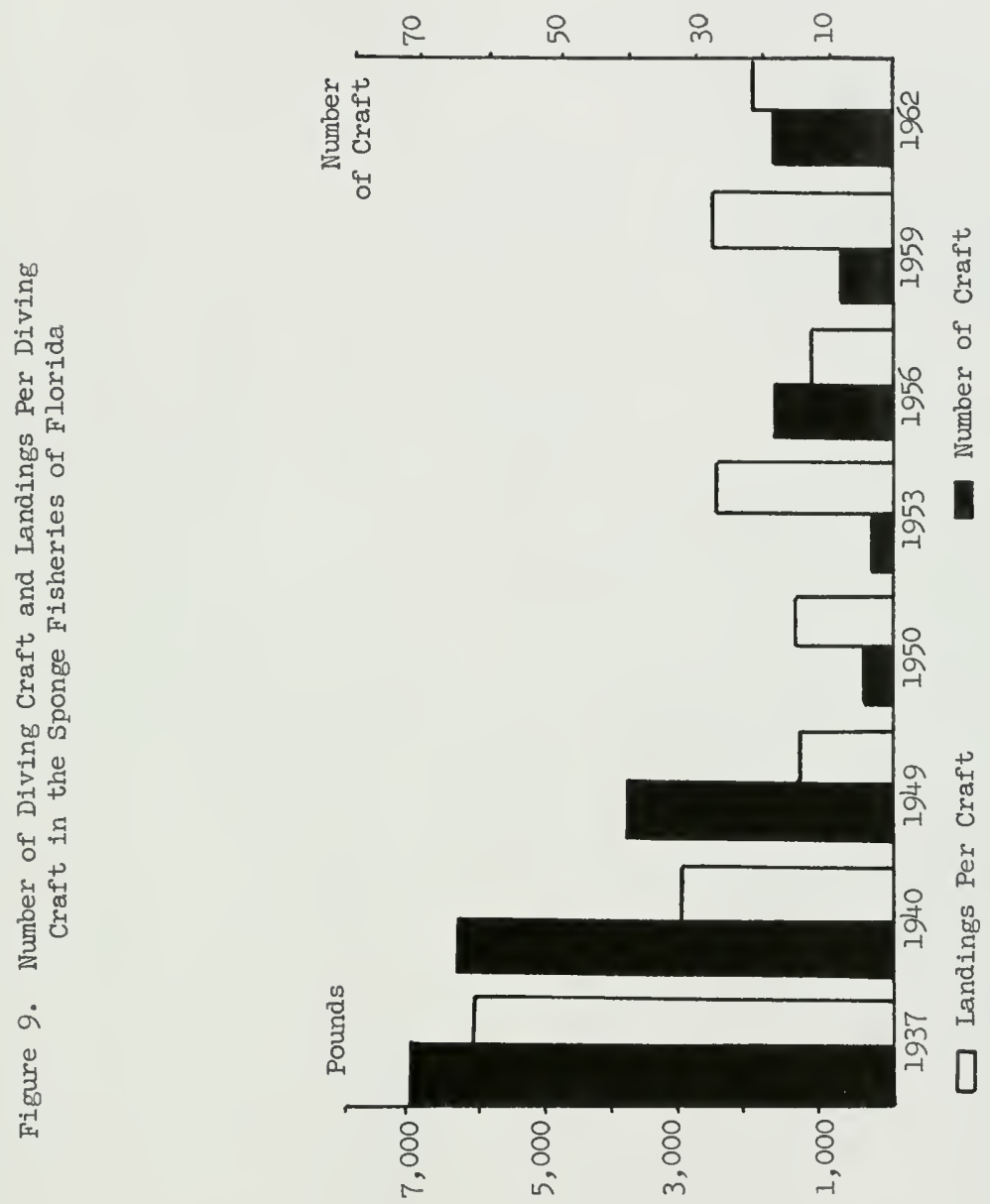

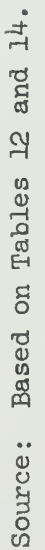


Figure 10. An Equilibrium Model for the Sponge Fisheries of Florida

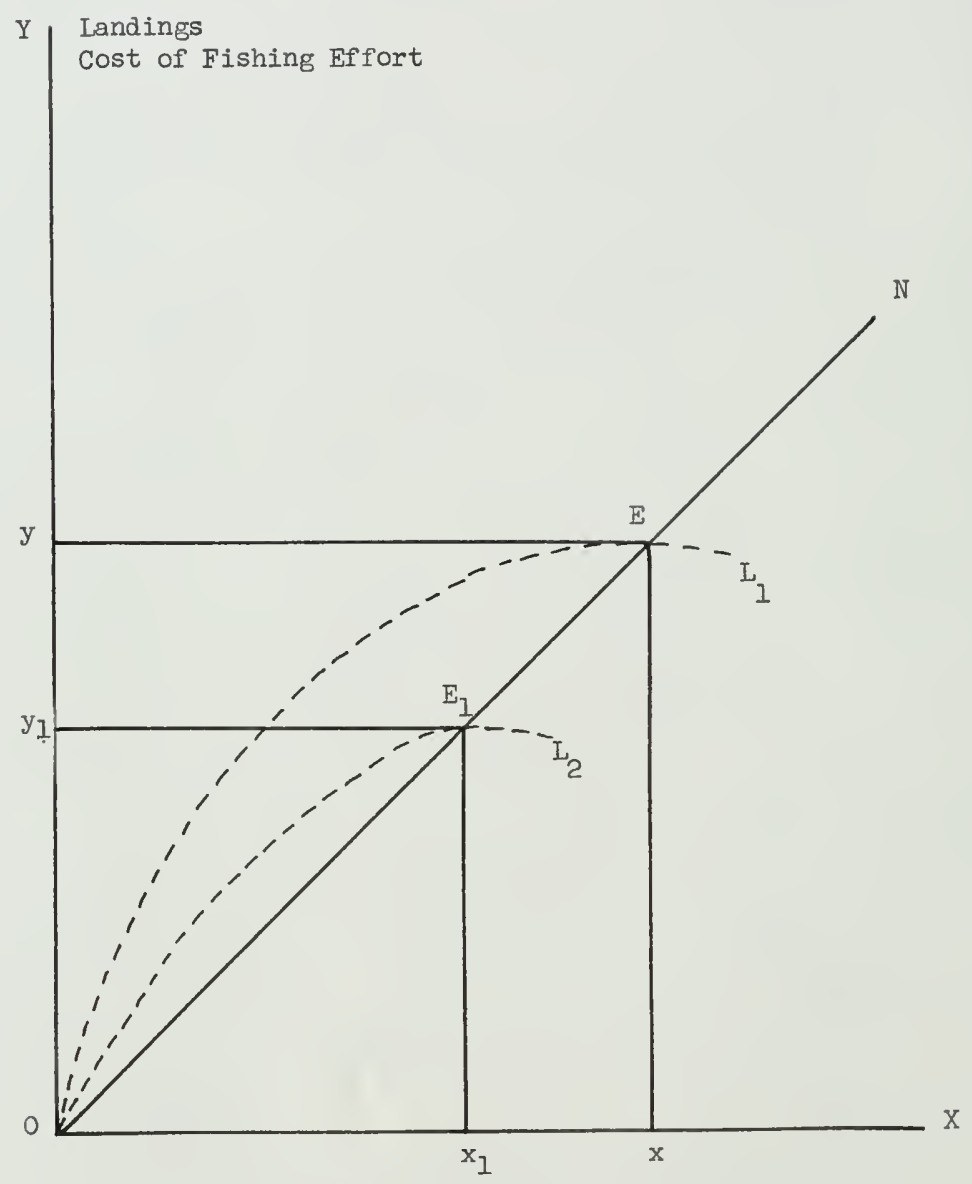

Physical Investment 
only if certain assumptions implied in the description hold true. A change in user tastes or preferences may change the market demand to such an extent that any fleet size based on a blological equilibrium may have no economic meaning. For example, if most current users of natural sponges declde to shift to symthetics, intensity of fishing effort as determined by fleet size and level of sponge population would be of limited economic significance. Also, a change in the relative importance of imports could sharply alter the market share and subsequently create unforeseen disturbances anong the operators of sponge craft. It is obvious that the existence of auch conditions could preclude the orderly adjustment described in the following paragraphs.

Sponge landings and cost of flshing effort are measured along the OY ax1s; the OX ax1s measures physical investment or the number of craft in the sponge I1sheries. The curve labeled $\mathrm{L}_{1}$ is a landings function, and it has a steadily diminishing slope because of the law of diminlohing returns; that 1s, as successive unfts of fishing craft are applied to a flxed amount of sponges, the amount of average landings per flshing craft, after a certain polnt has been reached, w111 decline. ${ }^{2}$ Any short run shifts in this curve would depend on uncontrollable natural elements, such as the diseases which hit the sponge beds in 1937 and 1949, and on the Intensity of fishing effort as determined by the number of craft in the sponge fleet. Curve $N$ is a cost function, and its slope represents the assumption that additional fishing effort w11 have no inflationary effect on the prices of factors of production.

$I_{\text {Boulding, p. } 589 .}$ 
This is a reasonable assumption in view of the fact that currently there are about seven former diving craft that could readily be made operational were 1t not for the current labor shortage. Also, any new craft constructed for the sponge fisherles would constitute such a small percentage of total shlp construction that any inflationary effect on the prices of factors of production would be negligible. Curve $\mathbb{N}$ also includes a normal return on investment which the owner of the flshing outf1t could have earned in some other type of fishing activity.

Polnt $\mathrm{E}$ in the diagran represents an equilibrium position. At $\mathrm{E}$ productive factors used in sponge f1sherles have been placed in tholr h1ghest paying euployments, and there is no incentive for the owners of these productive factors to move their resources from sponge f1shIng to another type of 1 ishing activity. ${ }^{2}$ Since $E$ represents an equilibrium position, at $E$, ox number of craft are landing oy amount of sponges with all enterprise units making a normal return on their investment. ${ }^{2}$ Suppose that a marine disease were to hit the sponge beds, greatly reducing the amount of sponges available for flshing. This would mean a downward shift of the landings function from $I_{1}$ to $I_{2}$. A drastic decline in the amount of sponges avallable for fishing will have an adverse effect on the productivity of each craft; that 1s, when the same number of craft have to share a smaller quant1ty of sponges, catch per craft will decline. Assuming that there is no change in market demand, th1s w1ll make sponge flohing lesa attractive, and there w1ll be a tendency for some craft to leave the pleet. The

$$
\begin{aligned}
& { }_{\text {Ib1d. , p. }} 565 . \\
& { }_{\text {Io1d. }}
\end{aligned}
$$


rate of exit will depend on the intensity of the disease plus fishing conditions in other types of fisheries.

A reduction in the size of the domestic sponge fleet may also occur as a result of a change in the relative importance of imports. In $1957,238,550$ pounds of natural sponges valued at $\$ 1,415,571$ were imported. Imports have declined steadily since then and in 1963 were 83,888 pounds valued at $\$ 805,103$ (see Table 39). This drop in the relative share of imports was caused primarily by the narrowing of the price differential between domestic and imported sponges. The substantial price advantage enfoyed by forelga producers has tended to diminish since 1961 (see Table 34), primarlly because of supply shortages encountered by the principal forelgn producers. The Increase In domestic sponge production and in the size of the sponge fleet since 1961 may be attributable to developments in foreign lands over which the Plsherman has no control, rather than to any fluctuations In the domestic sponge population and/or changes in the cost of fishing. By the same token, should foreign countries be able to solve their supply problems, in the future the relative importance of 1mports may improve. Such a situation is likely to create excess capacity in the domestic sponge fisheries regardless of the condition of the domestic sponge beds; however, in elther case an adjustment in the slze of the fleet w1ll take place eventually.

$\mathrm{E}_{1}$ in the diagram represents the new equilibrium position, and It was reached after $x_{1} x$ number of craft left the sponge fisheries. At $E_{1}, o x_{1}$ number of craft are landing oy amount of sponges. In the absence of additional domestic or forelgn natural disasters this reduction of flshing effort due to the reduction in the number of 
craft, coupled w1th proper conservation practices, w1ll tend to Increase the sponge population, thus pushing the landings function upward. I In addition to the sponge population and Intensity of Pishing, the level of equilibrium landings will also depend on conservation laws. By placing legal limits on the size of sponges that can be harvested, conservation authorities can move the level of equilibrium either to the right or left of the above diagram. Currently, both Florida and U. S. laws prohibit the harvesting of sponges w1th a diameter of less than f1ve inces when wet. This 18 done in order to glve young sponges a chance to propagate themselves, since three to four years need to elapse before a sponge larva can reach the legal flshing size. ${ }^{2}$

To be sure, the equilibrium positions described in the above paragraphs may never materlalize in actuslity. The concept of equilibrium indicates a position which provides no incentive or opportunity to move. An enterprise unit which is in equilibrium is obtalning the highest possible return on its factors of production and is maximizing its profits. Any changes from this equilibrium position will cause a decline in profits. Changes in market demand, In costs of production, and in the state of technology may constantly shlft the equilibrium position, because the enterprise unlt facing such changes wlll have to $r e a d j u s t$ the employment of its factors of production if they are to be utilized at their highest paying capacity. Since firms in disequilibrium will tend to move toward a

$$
\begin{aligned}
& \text { Istorr, p. } 67 . \\
& 2_{\text {Ibid., p. } 17 .}
\end{aligned}
$$


TABLE 15

AVERAGE LANDINGS PER DIVING CRAFT, 1937-1962

\begin{tabular}{|c|c|c|c|c|}
\hline Year & $\begin{array}{l}\text { Catch } \\
\text { Per Craft } \\
\text { in } \\
\text { Pounds }\end{array}$ & $\begin{array}{l}\text { Value } \\
\text { of Average } \\
\text { Catch in } \\
\text { Dollars }\end{array}$ & $\begin{array}{l}\text { Value of } \\
\text { Average Catch } \\
\text { Per Fisherman } \\
\text { In Dollars }\end{array}$ & $\begin{array}{l}\text { Average Price } \\
\text { Per Pound } \\
\text { in } \\
\text { Dollars }\end{array}$ \\
\hline $\begin{array}{l}1937 \\
1938 \\
1939 \\
1940 \\
1941 \\
1942 \\
1943 \\
1944 \\
1945 \\
1946 \\
1947 \\
1948 \\
1949 \\
1950 \\
1951 \\
1952 \\
1953 \\
1954 \\
1955 \\
1956 \\
1957 \\
1958 \\
1959 \\
1960 \\
1961 \\
1962\end{array}$ & $\begin{array}{l}6,551 \\
6,694 \\
4,264 \\
3,027 \\
\because . \\
\because . \\
\because . \\
\because . \\
\because 0 \\
1,458 \\
1,517 \\
2,133 \\
6,900 \\
2,375 \\
1,011 \\
1,129 \\
1,194 \\
877 \\
1,380 \\
2,663 \\
2,583 \\
2,583 \\
2,111\end{array}$ & $\begin{array}{c}13,259 \\
11,916 \\
10,564 \\
11,445 \\
\because \\
\because \\
\because \\
\because \\
\because \\
\because \\
10,307 \\
9,280 \\
14,961 \\
39,400 \\
18,825 \\
8,310 \\
8,221 \\
10,018 \\
5,256 \\
13,519 \\
29,605 \\
21,966 \\
26,712 \\
19,278\end{array}$ & $\begin{array}{c}1,678 \\
1,686 \\
1,485 \\
1,698 \\
0 \\
\because . \\
\because . \\
\because . \\
\because . \\
1,849 \\
1,547 \\
3,740 \\
6,567 \\
2,689 \\
1,385 \\
1,599 \\
2,102 \\
1,265 \\
2,661 \\
3,820 \\
3,661 \\
4,452 \\
3,213\end{array}$ & $\begin{array}{c}2.02 \\
1.78 \\
2.48 \\
3.78 \\
\ldots \\
0 \\
1 . \\
14.33 \\
\ldots \\
0 \\
7.07 \\
6.12 \\
7.01 \\
5.71 \\
7.93 \\
8.22 \\
7.28 \\
8.38 \\
5.99 \\
9.80 \\
21.12 \\
8.50 \\
10.34 \\
9.13\end{array}$ \\
\hline
\end{tabular}

Source: U. S., Fish and Wildilfe Service, U. S. Flehery Statist1es. 
TABLE 16

AVERAGE LANDIMGS PER HOOKCNG CRAFT, 1937-1962

\begin{tabular}{|c|c|c|c|c|}
\hline Year & $\begin{array}{l}\text { Catch } \\
\text { Per Craft } \\
\text { In } \\
\text { Pounds }\end{array}$ & $\begin{array}{l}\text { Value } \\
\text { of Average } \\
\text { Catch in } \\
\text { Dollare }\end{array}$ & $\begin{array}{l}\text { Value of } \\
\text { Average Catch } \\
\text { Per Plsherman } \\
\text { in Dollars }\end{array}$ & $\begin{array}{c}\text { Average Price } \\
\text { Per Pound } \\
\text { In } \\
\text { Dollars }\end{array}$ \\
\hline $\begin{array}{l}1937 \\
1938 \\
1939 \\
1940 \\
1941 \\
1942 \\
1943 \\
1944 \\
1945 \\
1946 \\
1947 \\
1948 \\
1949 \\
1950 \\
1951 \\
1952 \\
1953 \\
1954 \\
1955 \\
1956 \\
1957 \\
1958 \\
1959 \\
1960 \\
1961 \\
1962\end{array}$ & $\begin{array}{c}624 \\
428 \\
349 \\
229 \\
. . \\
\ldots \\
\ldots \\
\ldots \\
\cdots \\
\cdots \\
371 \\
461 \\
338 \\
243 \\
289 \\
125 \\
485 \\
207 \\
566 \\
388 \\
162 \\
470 \\
70 \\
123\end{array}$ & $\begin{array}{c}1,035 \\
1,018 \\
737 \\
700 \\
\ldots \\
\ldots \\
0 \\
0 \\
0 \\
0 \\
2,090 \\
2,653 \\
2,278 \\
1,376 \\
1,949 \\
946 \\
3,501 \\
1,598 \\
3,007 \\
1,970 \\
1,425 \\
1,981 \\
549 \\
852\end{array}$ & $\begin{array}{r}700 \\
519 \\
453 \\
439 \\
\ldots \\
\because \\
\therefore \\
\therefore \\
\therefore \\
\therefore \\
10 \\
1,027 \\
1,263 \\
1,101 \\
659 \\
585 \\
493 \\
1,517 \\
757 \\
1,386 \\
928 \\
722 \\
786 \\
305 \\
692\end{array}$ & 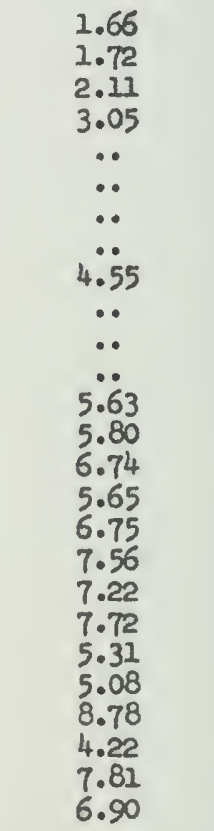 \\
\hline
\end{tabular}

Snurce: U..S., Fish and Wildlife Service, U. S. Fishery Statistics. 
TABLE 17

PERCENTAGE DISTRIBUTION OF LANDINGS AND VALUE OP LANDINCS BY MEITEOD OP OPERATION, 1937-1963

\begin{tabular}{|c|c|c|c|c|c|c|}
\hline \multirow{2}{*}{ Year } & \multicolumn{3}{|c|}{ Catch } & \multicolumn{3}{|c|}{ Value of Catch } \\
\hline & Hooking & Diving & Total & Eooking & Diving & Total \\
\hline 1937 & 25.29 & 74.71 & 100.00 & 21.73 & $27 \cdot 27$ & 100.00 \\
\hline 1938 & 20.46 & 79.53 & 100.00 & 19.88 & 80.12 & 100.00 \\
\hline 1939 & 21.66 & 78.34 & 100.00 & 19.08 & 80.92 & 100.00 \\
\hline 1940 & 16.51 & 83.49 & 100.00 & 13.79 & 86.21 & 100.00 \\
\hline 1941 & $\cdots$ & •. & •. & •. & $\bullet$ & $\bullet$ \\
\hline 1942 & - & $\bullet$ & - & $\bullet$ & $\bullet$ & $\bullet$ \\
\hline 1943 & . & & $\bullet$ & & $\bullet$ & $\bullet$ \\
\hline $\begin{array}{l}1944 \\
1945\end{array}$ & 23.71 & $7 \ddot{6} \cdot 29$ & 100.00 & $\ddot{8.97}$ & 91.03 & 100.00 \\
\hline 1946 & .. & $\cdots$ & $\bullet$ & $\bullet$ & $\bullet$ & $\bullet$ \\
\hline 1947 & $\cdots$ & $\bullet$ & $\cdots$ & $\cdots$ & $\bullet$ & $\bullet$ \\
\hline 1948 & $\ddot{0}$ & 8) & $\ddot{m}$ & $\ddot{0}$ & $\ddot{P}=7$ & $\ddot{m}$ \\
\hline 1949 & 15.14 & 84.86 & 100.00 & 12.43 & 87.57 & 100.00 \\
\hline 1950 & 58.64 & 41.36 & 100.00 & $57 \cdot 33$ & 42.67 & 100.00 \\
\hline 1951 & 60.49 & 39.51 & 100.00 & 59.55 & 40.45 & 100.00 \\
\hline 1952 & 44.80 & 55.20 & 100.00 & 44.55 & 55.45 & 100.00 \\
\hline 1953 & 45.09 & 54.91 & 100.00 & 41.13 & 58.87 & 100.00 \\
\hline 1954 & 39.74 & 60.26 & 100.00 & $37 \cdot 77$ & 62.23 & 100.00 \\
\hline 1955 & 54.47 & 45.53 & 100.00 & 54.26 & 45.74 & 100.00 \\
\hline 1956 & 31.42 & 68.58 & 100.00 & 29.69 & 70.31 & 100.00 \\
\hline 1957 & 74.55 & 25.45 & 100.00 & $72 \cdot 20$ & 27.80 & 100.00 \\
\hline 1958 & 53.54 & 46.46 & 100.00 & 37.40 & 62.60 & 100.00 \\
\hline 1959 & 21.98 & 78.02 & 100.00 & 18.20 & 81.80 & 100.00 \\
\hline 1960 & 25.84 & 74.16 & 100.00 & 14.74 & 85.26 & 100.00 \\
\hline 1961 & 15.99 & 84.01 & 100.00 & 12.57 & 87.43 & 100.00 \\
\hline 1962 & 20.89 & 79.11 & 100.00 & 16.47 & 83.53 & 100.00 \\
\hline
\end{tabular}

Source: U. S., Fish and Wildilfe Servlce, U.S. Flshery Stat1st1c8. 
new equilibrium, the significance of this concept lies in the fact that it indicates the direction in which economic changes can be expected to move.

Costs

In an attempt to obtain current operating stat1stics for the diving fleet in the sumer of 1964, the author intervlewed nine divlng craft captains in Tarpon Springs, Florida, by using the interview guide appended to this study (see Append1x A). At the time the survey was conducted only eleven diving craft were in operation in the sponge flsherles, and the findings of this survey as shown in Table 18 can be considered as representative of the total population. Taking the operating expenses in Table 18 and multiplying them by the number of craft in diving gives $\$ 56,342$ as the total operating costs of the diving fleet. This is considerably lower than the avaliable total operating costs 11 gure of $\$ 208,272$ in 1934 , mainly die to the fact that the number of craft has declined by 74 per cent between 1934 and 1953. The ressong for cost differences between 1934 and 1963 were explained in the preceding discussion of the early period (see pages 39-41).

Elther because of their 1gnorance of the subject or the1r unw1llIngmess to cooperate it was not possible to obtain cost data from sponge hookers. Personal observation by the author, coupled with opinions of fishermen in Tarpon Springs, revealed that operating expenses do not constitute an important factor in sponge hookdng. 
TABLE 18

AVERAGE OPERATING EXPENSES

OF NINE DIVING CRAFT, 1963

Item

Dollars

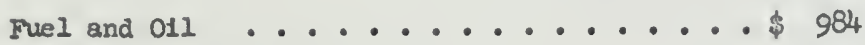

Painting and overhaul .......... 497

Food and supplies ........... 1,367

Ingine Repair ............ 426

Dlving susts ............. 300

Interest on $\$ 4,000$ Working Capital .... 320

Exchange Dues ............. 440

Total .................... \$34

Average Deviation ....... 136

Source: Survey of boat captains in Tarpon Springs, Fla., by the author, May, 1954.

Bmployment

As can be seen in Figure 4 employment in the sponge fisheries has been declining steadily since 1939. Up to 1950, employment in rechine diving exceeded that in hooking, but beginning in 1950, employment in hooking has exceeded employment in diving. The hooking fleet can be credited with having a better employment record since 1950, because there are more casual f1shermen ${ }^{2}$ in this type of sponge f1shlng. For example, during 1961, 56 per cent of the flshermen employed in hooking were casual workers. Very little capital investment is needed for hooking, since all that is required is a glass

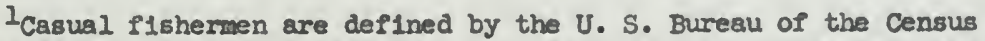
as flshermen who recelve less than half thelr annual incore from flshing. 
bucket, a pole approximately 20 feet long with a hook attached to the end, and any boat that can be manned by two people. It 18 estimated that not more than $\$ 1,300$ is needed to equip such an operation. Although detaching a sponge with a 20-foot pole requires some skill, such skill can be acquired with relatively little training and is not comparable to the elaborate sk1lls needed in machine diving. Consequently, many aged f1shermen and persons who bave other occupations in Tarpon Springs and Key hest have found the hooking type of sponge flshing to be a profitable side line. I Table 16 Indicates the value of average catch per fisherman in hooking operat1ons. The productivity of such fishermen 18 very low when the figures are compared with the value of average catch per flsherman for divling operations in Table 15. In calculating the value of average catch per flsherman the velue of total landings was divided by the total number of fishermen, ineluding casual f1shermen. This has deflated the productivity flgures for regular flshermen in hookdng and machine diving, but in no way has it disguised the productivity relationship between fishermen in hooking and machine diving.

Bmployment in diving has been relatively stable between 1960 and 1953. This is due mainly to the fact that it has been impossible to attract younger men into this occupation. ${ }^{2}$ With the exception of one, all 26 divers employed by the diving fleet today are divers of Greek descent who migrated to this country before World War II. The median age of these divers as of August, 1964, was 59 years. Any expansion in employment that has taken place during the last decade has almost

\footnotetext{
IInterview with Louis Smitzes, May, 1964. ${ }^{2}$ Toid.
} 
exclusively come from the ranks of ex-divers who took shore jobs after the 1949 sponge disesse. Professor John F. Storr of the State Un1versity of New York conducted a study of the Gulf of Mexico commerclal sponges in whlch he found that the diving craft with the youngest diver (all over 40 years of age) had a catch over 50 per cent greater than any other craft in the pleet in $1957 . .^{1}$ This does not strike one as something unexpected, since in a type of activity, such as diving, In which physical fitness is important, one would expect to find a positive relationsh1p between physical fitness and productivity. Younger divers, in addition to being able to spend more time under water, are capable of operating at greater depths. These two factors make it possible for them to explore new areas and harvest sponges which command higher market prices.

As can be observed from Table 15 average productivity flgures per Pisherman have been steadily increasing during the last six years. This improvement in productivity is primarily due to two factors: (1) a Beneral recovery of sponge beds from the disease of 1949, and (2) a scarclty of diving craft despite this recovery, due to a shortage of qualifled machine divers. The sponge Industry has trled to solve this manpower shortage by 1uporting divers from the Mediterranean, but such efforts have proved fruitless thus far. ${ }^{2}$ After enterlng the Unlted States imported divers often leave diving for more remunerative employment in Detrolt or other industrial centers of the North. ${ }^{3}$

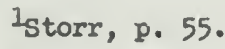

2Interview with Louis Smitzes, April, 1964.

3roid. 
Attempts are belng made by the Tarpon Springs Sponge Brehange to bring divers over 45 years of age from the Mediterranean. The Tarpon Springs Sponge Exchange Board of Directors reached this declition on the hypothesis that it would be difficult for divers of this age to find alternative employment opportunities. ${ }^{2}$ This may be an expedient solution to the acute shortage of divers in the short sun, but in the long run any Industry's survival depends on its ability to attract labor and capital. Bmploying older divers w1ll affect the average productivity of sishermen, but this may not prove to be very important since It has been pointed out prevlously that such productivity depends largely on the condition of the sponge beds rather than any effort exerted by man. The important thing is to find divers who can function even if their performance is somewhat hamered by age.

\section{Importance of the Sponge Industry to Florlda and the United States}

The past and present economic signiflcance of the sponge fisherles can be measured in terns of past and present performance in areas such as production and employment. In 1963, Florids fisheries landed $172,319,000$ pounds of sea products at a value of $\$ 27,718,000$ (see Table 19). The contribution of the sponge fisheries was only $\$ 387,261$, a very amall percentage of the total value.

In 1895, the sponge fisheries were Florida's most valuable fisherles, credited with one-third of the total landings for that particular year. A comparison of Pable 20 with Table 21 shows that while other types of flsheries have been enjoying economic gains 
TABLE 19

$$
\begin{aligned}
& \text { QUANTITY AND VALUE OF LINDINGS }{ }^{a} \text { BY } \\
& \text { COMMERCIAL FISHERIES IN FLORIDA, } \\
& \text { SELECTED YEARS, } 1880-1962
\end{aligned}
$$

\begin{tabular}{lcc}
\hline Year & Pounds $^{\mathrm{b}}$ & Dollars \\
\hline 1880 & 10,663 & 643 \\
1895 & 37,037 & 1,210 \\
1908 & 74,087 & 3,389 \\
1918 & 135,965 & 5,167 \\
1928 & 131,839 & 6,250 \\
1934 & 118,801 & 3,645 \\
1940 & 187,492 & 5,005 \\
1945 & 243,846 & 18,836 \\
1950 & 118,418 & 15,985 \\
1953 & 206,887 & 31,523 \\
1962 & 170,850 & 30,889 \\
1963 & 172,319 & 27,718 \\
\hline
\end{tabular}

Source : 1880-1953 from Osterbind, Flortda's Commercial Fisheries. 1962 from U. S., Bureau of Comerciel Fisherles, UnIted States F1sheries, 1962, C. F. S. No. 3471, Annual Surmary. 1963 from U. S., Bureau of Commercial Fisheries, Florlda Landings.

svalue in current dollars.

bpounds and dollars in thousands.

sponge fisheries until very recently have been experiencing nothing but deterioration. Taking the year 1895 as a base year, between 1895 and 1963 the index indicating the quantity of Florida landings increased to 503 while the index showing their value went from 100 to 2291 . In the sponge fisherles landings between 1896 and 1962 declined by 80 per cent whlle their value went up by only 52 per cent. It is obvioug that the sponge industry has not kept pace with the growth of other fishing industries. The contribution of the sponge fisheries in the provision of employment has been unimpressive. While employment in 
TABLE 20

INDEXES OF QUANIITY AND VALUE OF LANDINGS BY COMMERCIAI. FISHERIES IN FLORIDA, SELECTED YEARS, 1895-1963 $1895=100$

\begin{tabular}{lcc} 
& Quantity & Value \\
Year & Index in Pounds & Index In Dollars \\
\hline 1895 & 100 & 100 \\
1908 & 200 & 280 \\
1918 & 367 & 427 \\
1928 & 356 & 517 \\
1934 & 321 & 300 \\
1940 & 506 & 414 \\
1945 & 658 & 1557 \\
1950 & 320 & 1321 \\
1953 & 559 & 2605 \\
1962 & 505 & 2553 \\
1963 & 503 & 2291 \\
\hline
\end{tabular}

Source: Based on Table 19.

fisheries has sl1ghtly increased since the early $1900^{\prime} \mathrm{s}$, employment in the sponge flisherles has declined by almost 100 per cent (again see Table 4).

Although the sponge flsheries served the nation vell during World War II, measured in monetary terms the contribution of the Florlda sponge flsherles to the total Gross Nat1onal Product in 1963 was $\$ 387,261$, which can be considered as even less than a drop in a bucket.

Vlewed in this light one may conclude that the sponge fisherles of Florida are of little economic value to Florlda and the United States. This, of course, is a very limited interpretation. It has been mentioned previously that the sponge flsheries of Florlda are a unique 
TABLE 21

INDEXES OF PRODUCTION AND AVERAGE PRICE PER POUND

OF FLORIDA SPONGES, SELECTED YEARS, 1896-1963 $1896=100$

\begin{tabular}{lccc}
\hline Year & $\begin{array}{c}\text { Catch } \\
\text { Index }\end{array}$ & $\begin{array}{c}\text { Value of } \\
\text { Catch Index }\end{array}$ & $\begin{array}{c}\text { Average Price } \\
\text { Pex Pound Index }\end{array}$ \\
\hline 1896 & 100 & 100 & 100 \\
1906 & 250 & 313 & 125 \\
1926 & 178 & 244 & 160 \\
1931 & 158 & 224 & 141 \\
1936 & 261 & 377 & 144 \\
1941 & 85 & 500 & 585 \\
1946 & 69 & 949 & 1378 \\
1951 & 7 & 41 & 603 \\
1956 & 13 & 88 & 703 \\
1951 & 16 & 134 & 857 \\
1962 & 20 & 152 & 747 \\
1963 & 23 & 142 & 600 \\
\hline
\end{tabular}

Source: Based on Table 2 and Table 10.

product of the state of Florida, and in terms of tourist attraction they rank favorably with other Florida landmarks. ${ }^{1}$ Judging by the number of tourists seen daily on the sponge docks in Tarpon Springs, one may speculate that indirectly through tourist expenditures the sponge flsherles add equal or perhaps more value to the economy of Florida than they do through their landings of sponges. A ereat number of retall outlets selling curlos and providing sea food in Tarpon Springs capltalize on the sponge flsheries in their efforts to attract tourists.

IInterview with Louls Smitzes, May, 1964. 
CHAPTER III

THE PRODUCTION OF NATURAL SPONGES

\section{Sponge Fishing Methods and Auxiliary Procedures}

In Chapter II attention was given to economic developments in the United States sponge flsheries. Some of the production factors were dealt with in terms of the economic significance that such activities had on the developwent of the Plsherles. This chapter discusses production from a microeconomic viewpoint. The various productive activities which were vlewed from an aggregate viewpolnt in the previous chapter are now analyzed from an operational perspective. The following paragraphs examine the organization of fims In the sponge flsherles, their operating procedures, and distribution of earnings. An attempt is also made to discover the extent to which such factors affect supply and employment dependab1lity in the Industry.

Commerclal sponges are harvested by wading, nude diving, fernezen diving, dredging, hooking and machine diving. The market value of a sponge often depends on the method by whlch it has been obtained, since sponges taken from deep waters have qualities superior to those harvested in shallow waters.

\section{Curing the sponge}

When the living sponges are brought to the boat they are at ilrst squeezed by the crew to initiate the maceration of the IIving material. 
The next step is to place the spongea on the deck with the root down to facilitate the draining out of the gurry. In order to expedite the death of the living matter in the sponges the crew often trods on them with their bare feet. In order to avold the drying of the sponges during this decomposition of the soft tissue they are covered by a wet burlap sack. To assure uniform decaylng sponges are turned several times since uneven or excessive decomposition reduces the market value of the product.

Under sunny skles this process of decaylng w1ll usually last no longer than one day, and the followlng day the sponges are ready for their final cleaning. Final cleaning starts by washing the aponges several times with sea water, since washing them with fresh water tends to make sponges look darker. After the final rinsing the sponges are thrown forcibly agalnst the deck to knock out the dead shrimp and other forefgn material that may have lived in the larger canals of the sponges. Then the outer surfaces of the sponges are scraped with short-bladed knives to remove the last traces of the skin. Finally, the clean sponges are strung on rope yarns, technlcally known as "stefan1," and tied to the ra1le of the boat for drying. After drying the stefan1, each consisting of 150 sponges, are stored In the forward hold of the boat. 1

The selling of sponges by flshermen

The information presented in this section is based primarily on the author's personal observation and information collected from residents of Tarpon Spring3 in the summer of 1964.

IInterview with John Samarkos, June, 1954. 
After the fishermen return to shore the sponges are stored in the Tarpon Springs Sponge Exchange. At the Sponge Exchange there are about one hundred jall-like cells. Each captain occuples one or more cells depending on the amount of his catch, and he deposits and keeps his sponges in the cells until the day of selling. Prior to the sale the boat crew strings the sponges on yarn 5 feet long, known in the trade as bunches. The number of sponges on each bunch depends on the size of the strung sponges.

Whenever sponges are avallable for sale the buying and selling takes place twice a week on Tuesday and Frlday at 9:30 A. M., but not on Good Friday. If on the market day there is more than one captain desiring to sell his catch, then the selling order is determined by drawing a ballot.

The Tarpon Springs Sponge Exchange b1lls the captain for 2 per cent of his sales for the servlces of protection, storage, and auctioning that it provides. If the captain is a member of the local Greek Orthodox Church another 0.5 per cent 18 withheld and donsted to the church of St. N1cholas in Tarpon Springs.

The sponges are sold to the packers at auct1on. A sponge auction is carried on in a silent manner with the packers carefully examining the sponges, while at the same time marking their b1ds on pleces of paper. The packers are experfenced buyers, and their offers are based on the slze and quality of sponges, this belng established through a visual examination.

The auctioneer awards the sponges to the highest bldder, provided the seller considers the amount adequate. The seller is permitted to refuse an offer if he belfeves that the price is too low. Blds often 
differ by a few dollars, and the prices pald for any variety of sponge depend to a large extent on their size and other qualities as described In Chapter I.

\section{Units of Operation}

Of all the possible operational methods only hooking and machine diving are being practiced today by sponge fishermen in the United States. Although the analysis of the fisheries in the previous chapter was undertaken in terms of a sponge fleet, one must not forget that this term in no way implies any common ownership or centralized direction of activities. As a matter of fact, of the thirteen diving outfits in operation in 1963, none had more than one omer. The same is true for hooking operators.

It w11 be convenient to think of each craft in the sponge flsheries in terms of a separate enterprise. The objective of each enterprise unit is to maximize its landings. The comblnation of the three factors of production, that 1s, capital, management, and labor, in an effort to achieve the enterpolse objective w1Il depend primarily on the s1ze and complexity of the operation. For example, in hooking operations it 18 not uncomon for the ommer - capltalist to be also the manager and captain and to provide at least half of the labor requirements of the enterprise. On the other hand, one often finds separation of ownership and management in diving operations. Of the thirteen diving outfits operating in 1963, four or approximately 31 per cent were characterlzed by absentee ownership. ${ }^{2}$ Cenerally

Isurvey of nine diving craft captains by the author in Tarpon Springs, Fla., May, 1964.

2Ibla. 
speaking, in sponge fishing as in many other forms of production, as the size and complexity of the enterprise increases so does the division of labor. Such Increased specialization increases the number of people engaged in the supply of the productive factors necessary to discharge the enterprise objectives.

In 1963 , there were thirteen diving outfits in the sponge fisheries of Florida. Between 1962 and 1963, the number of craft in the sponge fleet was reduced by five, largely due to an absence of quallfied divers. The median length of a diving craft was 47 feet. The median age for each diving outf1t was 31 years. The newest craft was 22 years of age, while the oldest craft was constructed 47 years ago. These diving outfits had an average market value of $\$ 17,000$, which by f1shery standards is constdered to be a substantial investment. I

Due to their small size, intermittent nature of operations, and widely acattered locations, it was not possible to determine the precise number of hooking craft for the year 1963. According to the statistics released by the Bureau of Commercial Fisheries, there were 81 hooking outfits in 1952. Although the Bureau publishes statistics on casual workers, no such distinction is made for casual employment of capital. Informed sources in the sponge fisherles are of the opinion that most hooking craft harvest sponges on a part-time basis. ${ }^{2}$ The same sources estimate the number of hooking craft to have been around 80 in 1963. Such craft usually have a length of about 15 feet. Most of them are propelled by a motor; however, there are some that

IItoid.

2. Ib1d. 
employ oars and sails. The capital required to undertake such an operation may vary wldely depending on the size of the boat, type of motor, et cetera, w1th $\$ 1,300$ quoted as an average flgure by most bookers in the trade.

\section{Distribution of earnings}

The following discussion will center around practices in machine diving operations. The process of distributing earnings has been institutionalized in this type of sponge flahing.

At the beginning of each trip it is the owner's responsiblilty to furnish the ship with all the necessary equipment. The owner is expected to pay for all major repairs and to have the craft in perfect operational condition. In adaltion, it is the duty of the owner to supply his crew with advance payments, known as "platika," from the time they have agreed to work for him unt1l the final settlement of accounts approximately $81 x$ months later. Owners are expected to take care of any emergencles that may arlse in the familles of their crew, and if the final proceeds are not adequate to cover the advances made to the crew, owners are expected to write off such $1038 \mathrm{~s} .1$

Currently, each diving craft consists of $s 1 x$ members--the captain, two divers, an engineer, a lifeline tender, a cook, and a deck hand. With the exception of one case, the captaln was always one of the divers. The rest of the crew is hired by the captain for a duration of 8 ix months. Crew members have no stake in the operation except the investment of their time. Their remuneration depends on the value of the catch plus the shares whlch each one 18 ent1tled to recelve from

Interview with Louis Smitzes, July, 1964. 
this catch. It was reported that the former depends on the size of the catch and 1ts market price; the latter depends at any given time on the complexity of skills supplied by each crew member.

The shares of the participants are also influenced by the amount of the operating expenses, such as groceries, fuel and oil, diving sults, and minor repairs. One may say that, in a sense, at the beginning of each six months the craft is turned over to the crew, which is then responsible for all operating expenses plus any damages to the craft during the trip. After the deduction of all the specified expenses the remainder is divided by the participants in the operation as follows: $:^{1}$

\begin{tabular}{ll} 
First diver & 2 shares \\
Second diver & 2 shares \\
Engineer & 1.5 shares \\
Lifeline Tender & 1.5 shares \\
Cook & 1 share \\
Deck hand & 1 share \\
Boat & 3 shares \\
\multicolumn{1}{c}{ Total } & 12 shares
\end{tabular}

When the captain is not the owner the latter gets 2.5 shares, with 0.5 share golag to the captain. Thus, the remuneration of each fisherman is contingent upon the success of the individual fishing trip. This sharing system offers a strong incentive to the fishermen to obtain the largest possible catch and at the same time to keep operating expenses at a minimum. If the trip proves not to be 
successful the owner theoretically loses nothing except depreclation on his investment and interest, efther implled or actual, incurred in equipping the craft. However, when a trip proves to be unprofitable owners are expected to wrlte off the advance payments made to the crew. $^{2}$

In hooking operations the pattern of distribution of the proceeds from the catch is less rigidly defined. Due to the large number of part-time workers and to the ease of operation, attempts to inst1tutfonslize the distribution of earnings have not been successful. Most hooking operations consist of two people working from one boat. A rather common practice among those engaged in hooking on a fulltime basis is to deduct all operating expenses from the proceeds and then to divide the remainder by 2.5 , each individual recelving one share and a half share golng to the owner of the boat.

Figure 6 and Figure 11 indicate that enterprise units engaged in diving operations have been more productive than those engaged in hooking operations. For diving outfits the catch per enterprise unit has always been higher both in terms of welght and value.

Figure 12 indicates that labor has also been more productive in diving operations. This is to be expected, since the productivity of any combination of labor and capital tends to increase as the ratio of capltal to labor goes up. The value of average catch per flsherman is higher in diving than it is in hooking. This is an indication of the higher productivity of flshermen in diving, but the actual remuneration recelved by each fisherman in diving will depend on the

${ }^{1}$ Interv1ew w1th John Semarkos, May, 1964. 

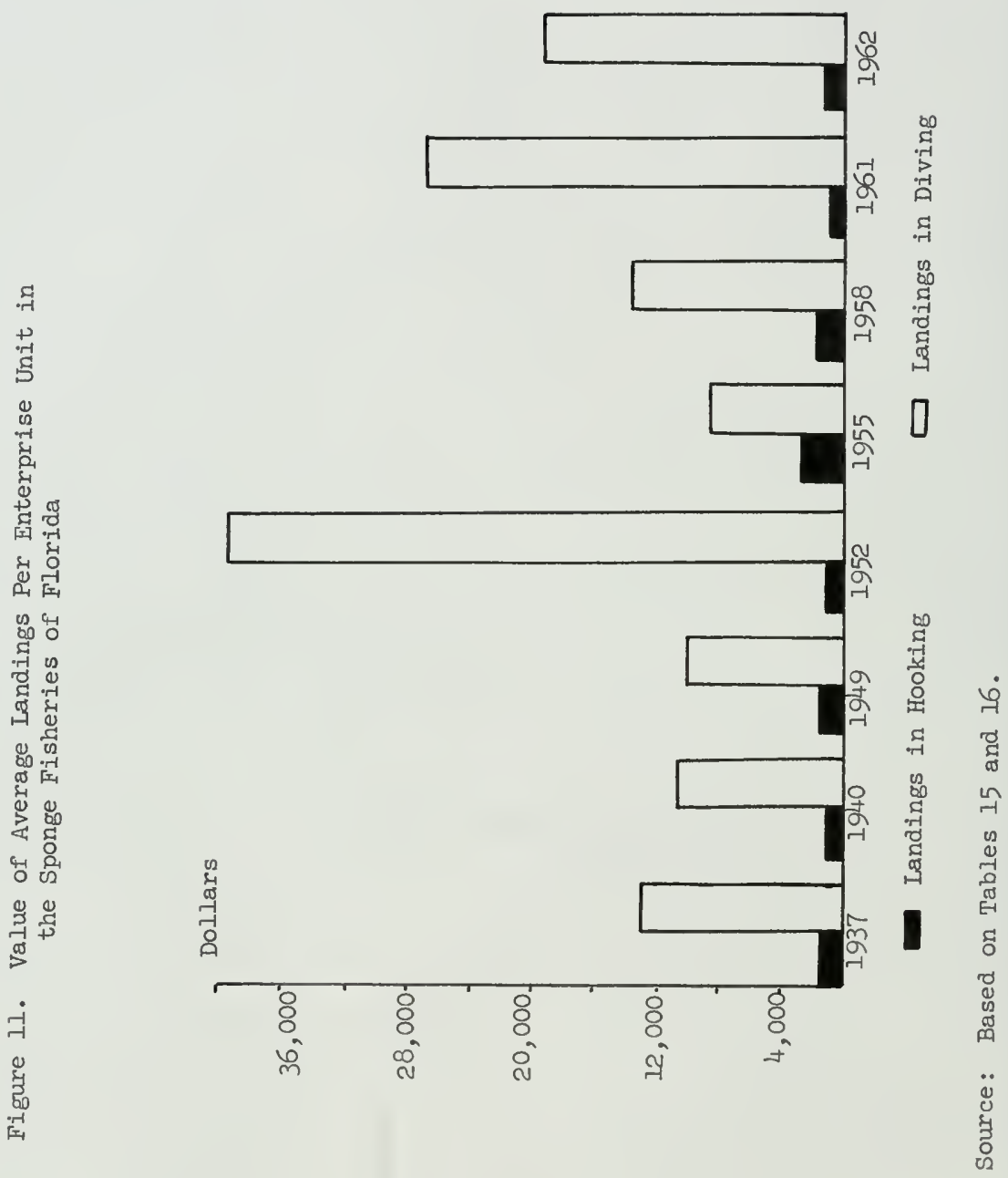

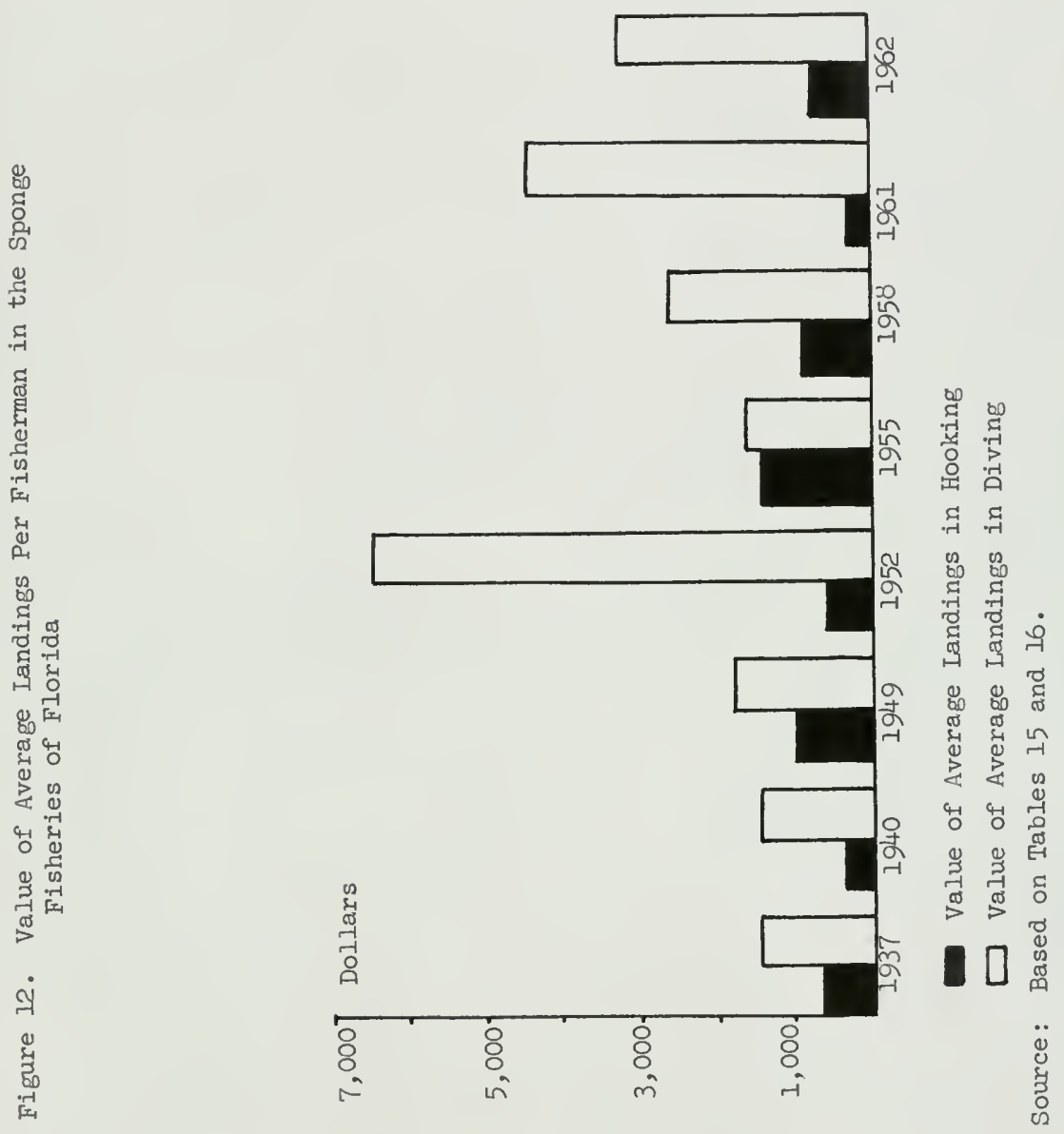
shares he recelves, as determined by the skills he supplies in the flshing process.

Cost structure

The following anslysis of costs 18 based on the information recelved from the captains of nine of the eleven diving craft operating in 1954. It was not possible to recelve much meaningful information from hooking outfits. Table 18 indlcates the average annual operating expenses of diving outf1ts. All the operating expenses are deducted before the distribution of earnings.

The value of landings per diving outflt was $\$ 26,992$ in $19,3$. After deducting all operating expenses as shown in Table 18, the remainder, \$22, 658, was distributed among the participants in the following fashion:

$\begin{array}{llr}\text { Diver } & 2 \text { shares } & \$ 3,776 \\ \text { Englneer } & 1.5 \text { shares } & 2,832 \\ \text { Lifeline Tender } & 1.5 \text { shares } & 2,832 \\ \text { Cook } & 1 \text { share } & 1,888 \\ \text { Deck hand } & 1 \text { share } & 1,888 \\ \text { Boat } & 3 \text { shares } & 5,664\end{array}$

In most cases the senfor diver, who was also the captain, recelved $\$ 4,720$, and if he was the owner of the craft h1s total recelpts amounted to $\$ 9,440$. In addition to such earnings, a 11 crew members recelved free food and lodging throughout the durstion of the trip.

\section{Return on Investment}

The value of the average diving craft is estimated around $\$ 17,000$. This is the figure that nine of the eleven craft owers mentioned as 
the price for which they would be willing to sell their boats. Being an asking price, it is possible that this ifgure is above the amount that potential buyers would be wliling to pay. Since only two shipa have changed ornership during the past fifteen years, in the absence of any recent selling transaction 1 t was impossible to obtain a more accurate market value than the price asked by the present owners. In 1963 , the average diving craft claimed 2.5 shares out of the total proceeds. This was equivalent to $\$ 4,720$, or a gross return of approximately 27.76 per cent on Invested capital. As explained before, the element of risk and operating expenses inherent in sponge fishing are spread among all participants in the process of production. This 18 in contrast to other types of economic activity where all risks rest wholly with the entrepreneur or 1nvestor. To be sure, craft owmers are st111 subject to the risk of losing their total invertment, that 1s, the ship may sinis or they may be unable to recover the money paid in advance to the crew.

It is possible to purchase insurance to cover sinking, but wthout exception no owner carrles such insurance because of 1ts very high cost, between $\$ 900$ and $\$ 980$ a year. ${ }^{2}$ Although such steep insurance rates imply rather high $108 \mathrm{~s}$ experiences among marine vessels in general, this experlence appears not to be applicable to the aponge fleet. Since the oldest craft in the sponge pleet is 47 years old and the newest has an age of 22 years $^{3}$ one can surmise that fishing craft in the sponge fleet have had a rather favorable accident record.

Interview with John Samarkos, May, 1954.

2 Ibid.

3 see page 85. 
Owners are responsible for any major repalrs needed to make the craft operational prior to the beginning of each semt-annual f1shing trip. However, in informal conversations with the author, crew members cited cases in which dishonest craft owners deliberately neglected proper care and malntenance, since any repairs that occur during the trip are deducted from total recelpts before arriving at the value of a share. Since owners take a reduced risk, a return of 27.76 per cent may be an excessive remuneration for the functions they perform. Under present conditions and barring any unforeseen developments it is possible to recoup the entire investment in a diving craft in a period of a little over three years.

It is obvious that such excess earnings by craft owners cannot last over a long perlod of time. It has been explained in the prevlous chapter that excess earnings mey attract additional entrepreneurs into sponging and that as the number of craft exploiting glven sponge grounds gоев up landings per craft and, consequently, returns on each owner's investment will go down. The high level of present earnings can be explained in terms of a quasi-rent. The return on any factor in temporarily fixed supply is called a quasirent in economic terminology. ${ }^{1}$ It has been mentioned prevlously that, due to an acute shortage of divers, the alze of the diving fleet was reduced by 34 per cent from 1962 to 1963. The improvement of sponge bed productivity coupled with a smaller fleet has increased the amount of catch per craft. Present craft owners will keep recelving

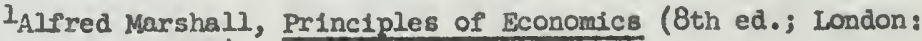
Macmillan Co., 1922), pp. 614-615. 
this quasi-rent unt1l the supply of labor can be increased, efther by Importing divers from the Mediterranean or by training local people.

It is possible that part of these excess earnings by one factor of production, namely capital, can be approprlated by labor, but even under conditions of the present labor shortage this is not likely to happen for several reasons. First, all of the present divers are elderly people with little alternative job opportunities elsewhere; second, such people are culturally tied to a minority comanity in Tarpon Springs and are unwilling to take chances in a foreign environment. It was reported that the jority of these fishermen migrated to the United States in the early twenties, but most of them st1ll speak only a few words of English. Third, most of these people have a certain pride in their occupation; their involvement in their jobs is romantic as well as economic, and one may assume that they would not think of moving or quitting even under the most adverse conditions. In short, this represents an unusual situation where the workers have not taken advantage of their increased bargaining power.

\section{Dependabillty of Supply}

It has been pointed out in the preceding chapter that, given the size of the fleet, the supply of sponges at any time depends on natural elements, such as weather conditions and marine diseases. It can be observed in Figures 13 through 16 that sponge landings from 1961 to 1964 have generally followed the same trend as total Florida landings, Indicating that sponge landings like any other fishing activity depend largely on the clemency of the weather. Of course, 
Figure 13. Monthly Comparison of Total Florida Landings and Sponge Landings, 1961

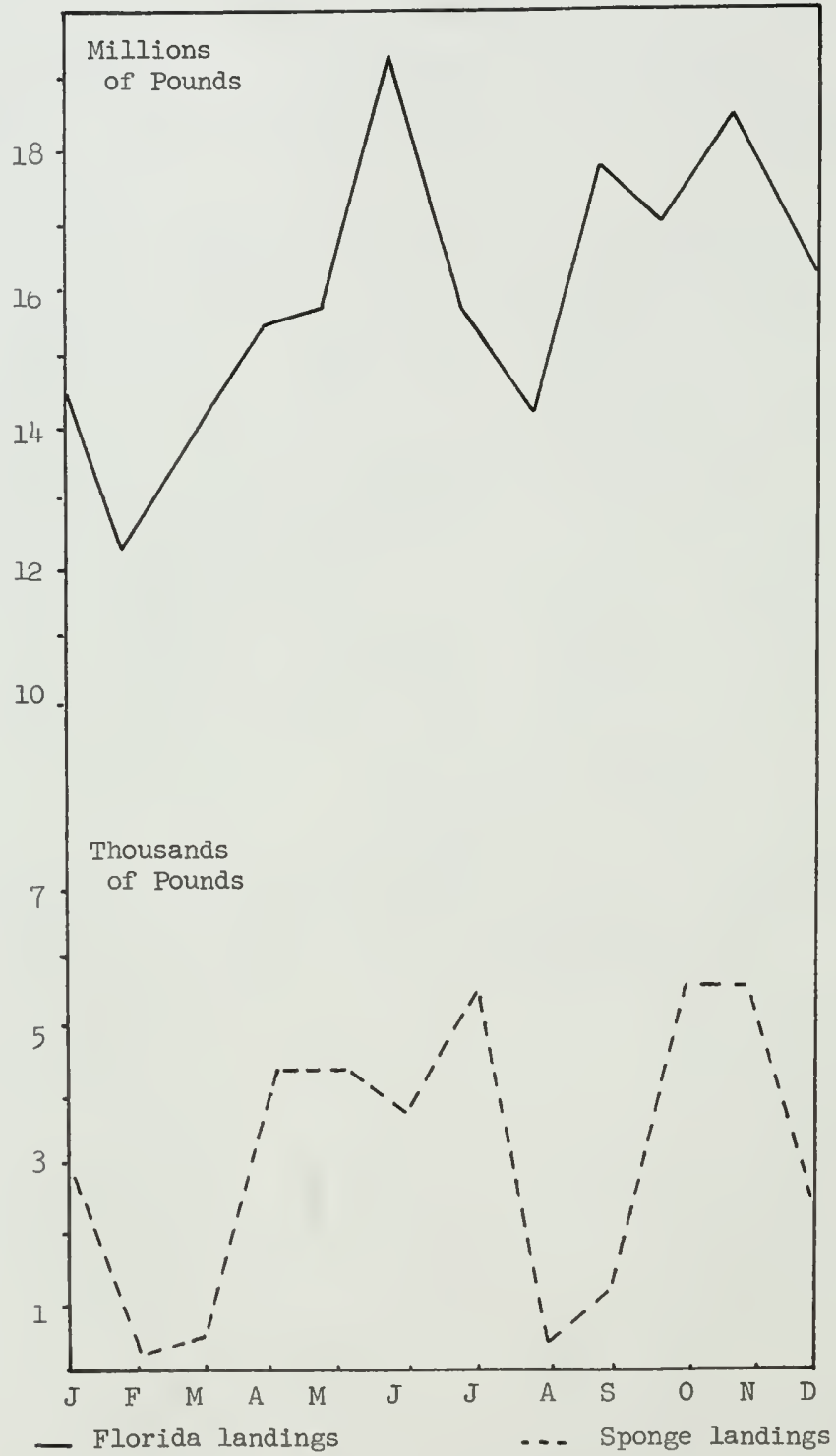

Source: Based on Tables 22 and 23. 
Figure 14. Monthly Comparison of Total Florida Landings and Sponge Landings, 1962

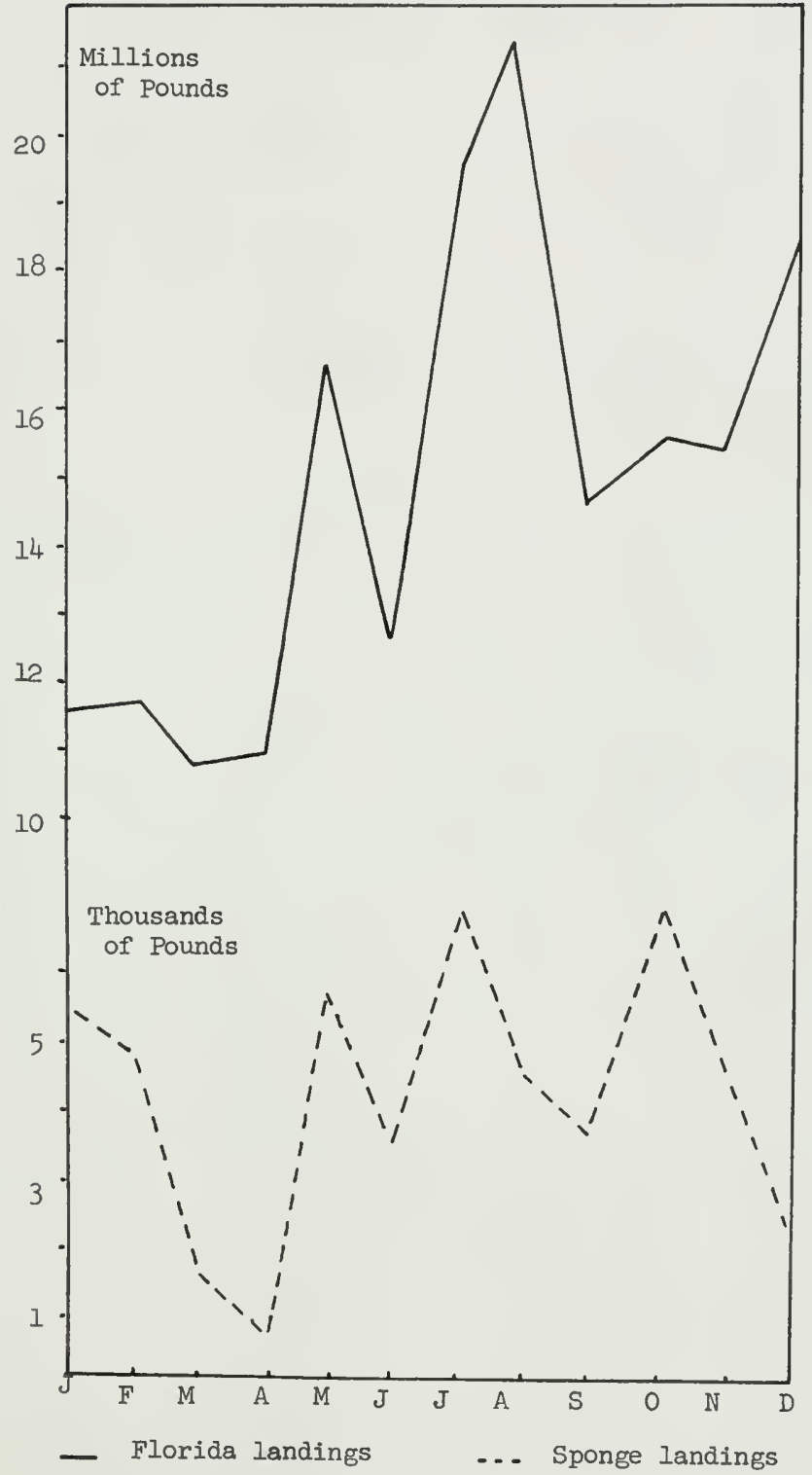

Source: Based on Tables 22 and 23. 
Figure 15. Monthly Comparison of Total Florida Landings and Sponge Landings, 1963

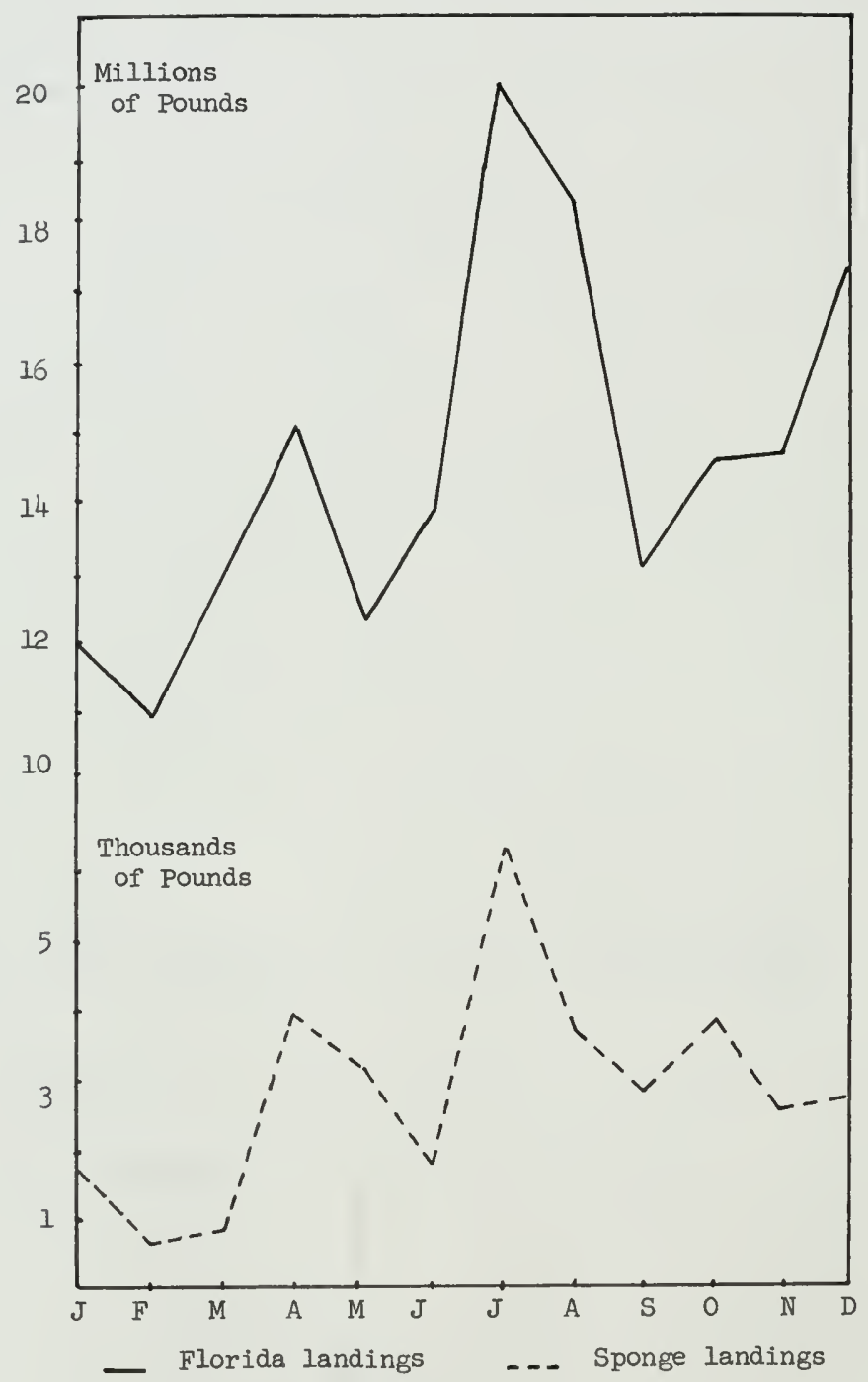

Source: Based on Tables 22 and 23. 
Figure 16. Monthly Comparison of Total Florida Landings and Sponge Iandings, 1964

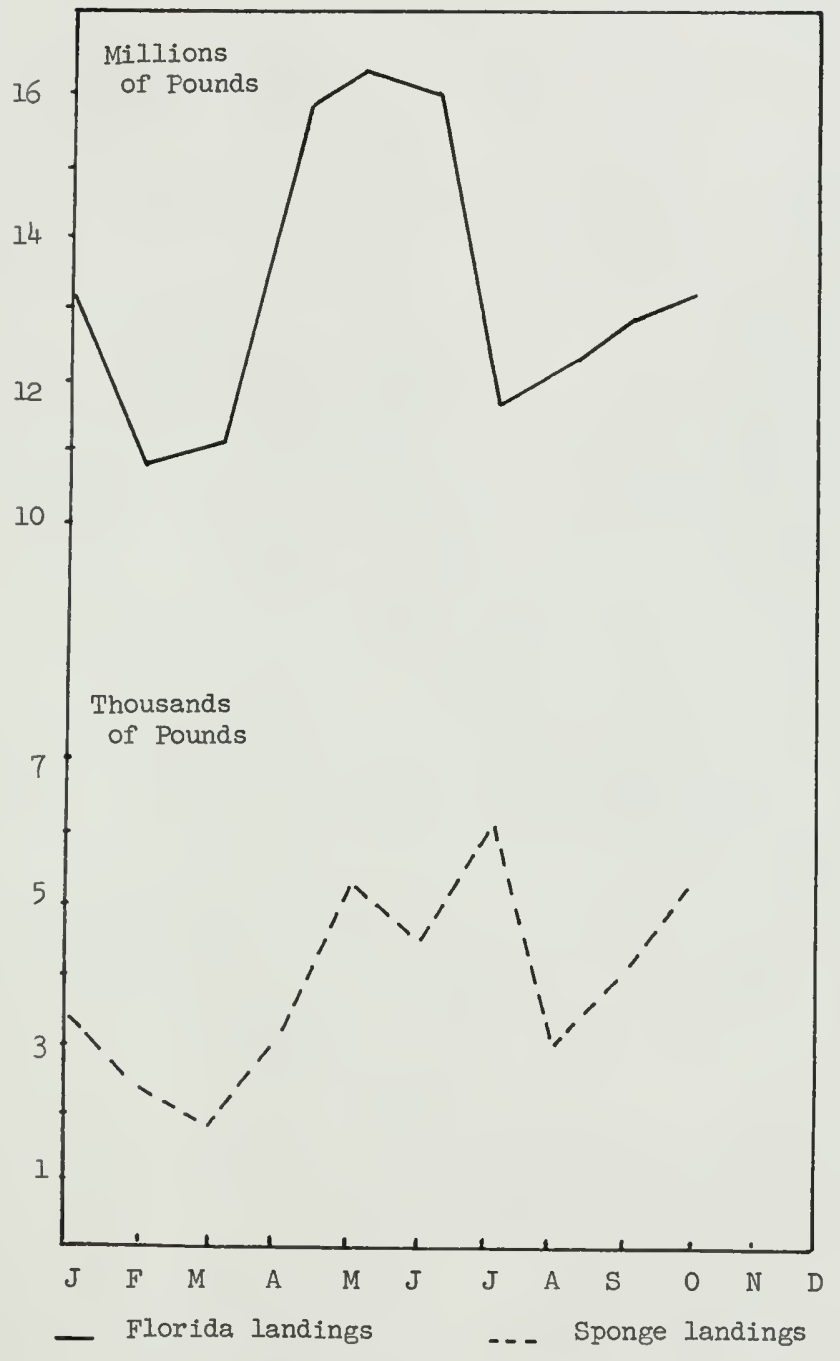

Source: Based on Tables 22 and 23. 


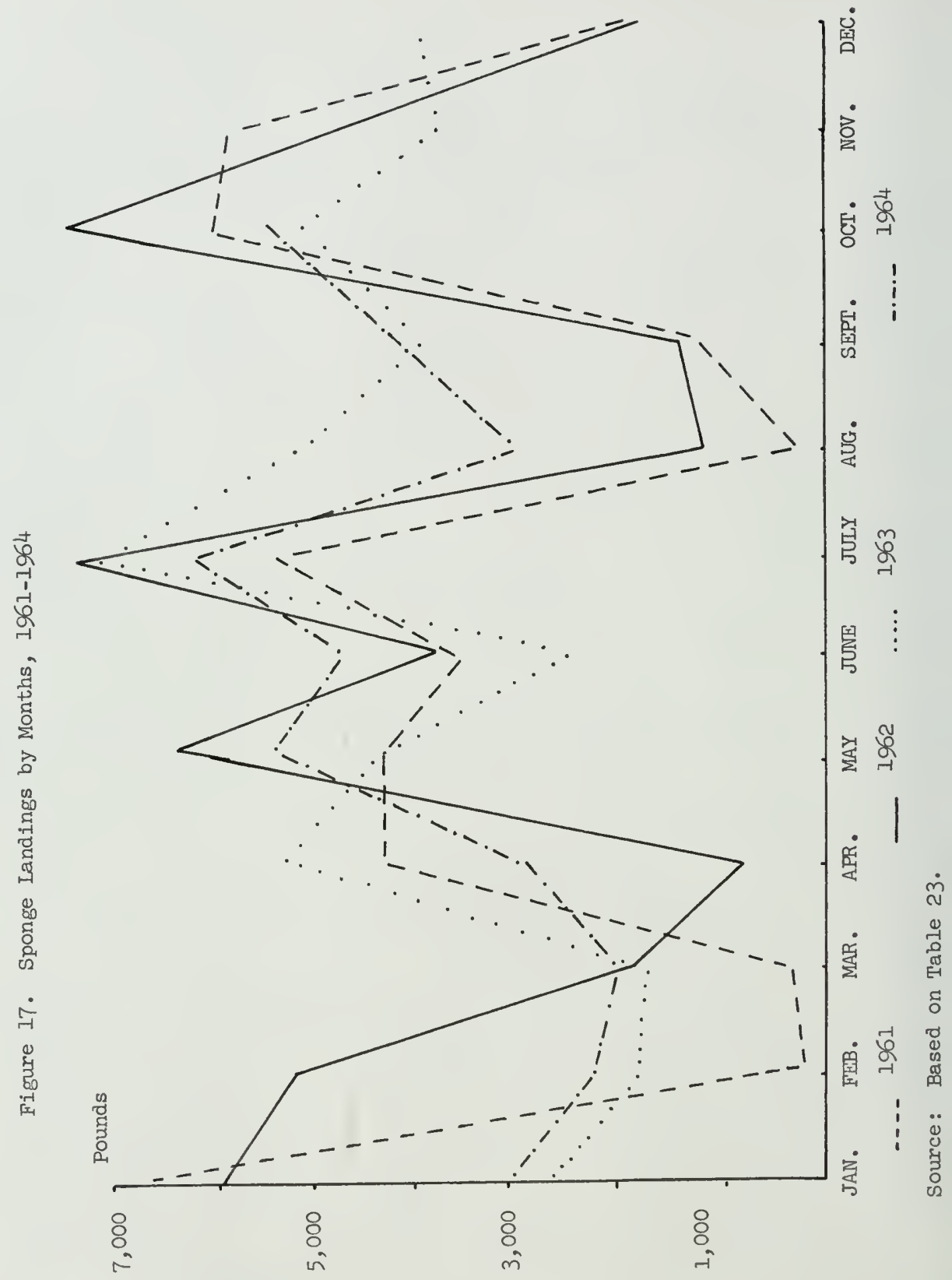


In instances where the sponge beds suffer from an epldemic disease, sponge landings may move in an opposite direction from total landings If such a disease affects only the sponges and no other inhabitant of the ocean. For the years 1961 to 1964 the conditions of the sponge beds can be described as normal. 1 It can be seen that sponge landings attributed to the months of August and December have consistently been lower and not in accord with total Floride landings. This is so because very little sponge fishing is performed during these two months. Traditionslly, the sponge fleet returns to port early in August and December for the celebration of religious festivities and a sort of semi-annual settlement of earnings. ${ }^{2}$ This 18 also the time when the craft undergo any major repairs or overhauling that may be necessary.

Figure 17 shows sponge landings by months for the pest four years; with the exception of 1963 and part of 1964, landings as measured in pounds have gone up. Constant improvement of catch can be taken as an Indication of the recovery of the sponge beds. Sponge landings have decreased in 1963 and part of 1964, but this decrease was the result of a reduction in flshing effort caused by a shortage of qualified machine divers rather than an unhealthy condition in the sponge beds.

\section{Supply and price relationship}

BIgure 18 compares average per pound prices recelved by sponge fishermen with average per pound prices for all fishery products since 1946. As the chart indicates, average sponge prices have fluctuated

Interview w1th Louls Smitzes, June, 1964. 2 I01d. 
Figure 18. A Comparison of Average Per Pound Prices Received by Fishermen and Sponge Fishermen in the United States

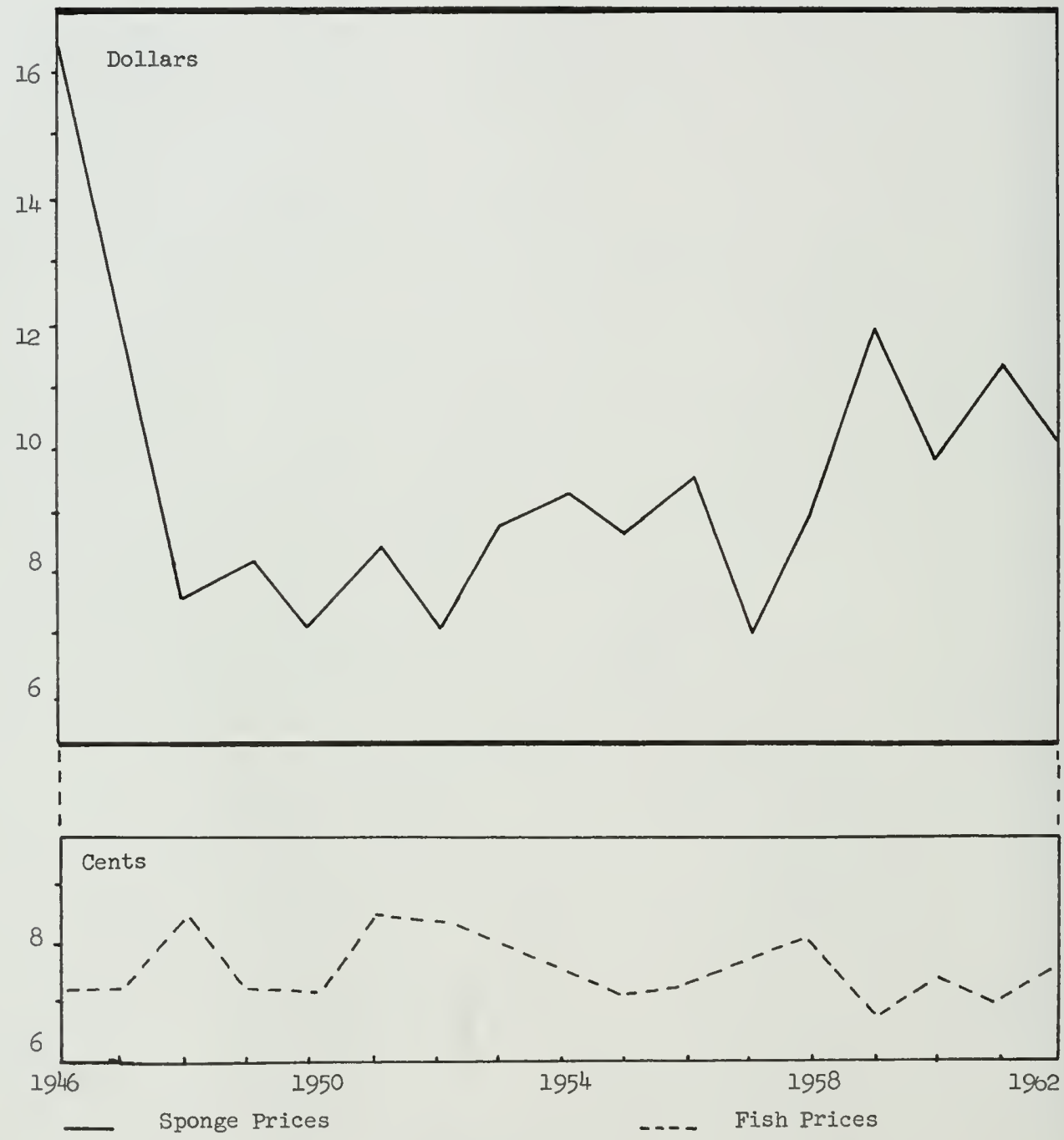

Source: Based on Table 24. 
TAEIE 22

FLORIDA LANDINGS BY MONTHS, 1961-1964

\begin{tabular}{|c|c|c|c|c|}
\hline \multirow[b]{2}{*}{ Month } & \multicolumn{4}{|c|}{ Pounds } \\
\hline & 1961 & 1962 & 1953 & 1964 \\
\hline $\begin{array}{l}\text { January } \\
\text { Pebruary } \\
\text { March } \\
\text { April } \\
\text { May } \\
\text { June } \\
\text { July } \\
\text { August } \\
\text { September } \\
\text { October } \\
\text { November } \\
\text { December }\end{array}$ & $\begin{array}{l}14,625,418 \\
11,970,142 \\
13,626,493 \\
15,266,660 \\
15,541,449 \\
19,686,964 \\
15,450,754 \\
13,957,106 \\
17,880,870 \\
16,668,825 \\
18,519,042 \\
16,393,804\end{array}$ & $\begin{array}{l}11,687,664 \\
11,845,146 \\
10,739,310 \\
10,917,340 \\
16,585,191 \\
12,354,288 \\
19,018,984 \\
21,780,056 \\
14,477,191 \\
15,431,087 \\
15,370,418 \\
18,643,341\end{array}$ & $\begin{array}{l}11,815,097 \\
10,783,364 \\
13,002,772 \\
14,891,300 \\
12,061,589 \\
13,612,453 \\
20,137,744 \\
18,138,030 \\
12,896,432 \\
14,764,588 \\
14,761,100 \\
17,604,619\end{array}$ & $\begin{array}{c}13,101,828 \\
10,614,230 \\
10,838,582 \\
15,724,086 \\
16,174,562 \\
16,186,842 \\
11,552,690 \\
11,990,636 \\
12,816,281 \\
13,185,492 \\
\ldots \\
. .\end{array}$ \\
\hline Total & $189,587,527$ & $178,849,916$ & $172,319,178$ & $82,640,076$ \\
\hline
\end{tabular}

Source: U. S., Bureau of Camerciel Flsheries, Florida Landings.

more than average prices for other fishery products. It has been pointed out previously that quality and supply are the two main factors determining the prices received by sponge fishermen. In Table 10 a comparison of average prices and total quantity landed reveals that with a few exceptions every Increase in quantity landed was accompanied by a decrease in the average price received by sponge fishermen.

\section{Comparison with Earnings in Fisheries}

According to the 1960 United States Census of Population the median income of f1shermen in Florida was $\$ 2,113$. In 1960, the value of average catch per hooking craft was $\$ 1,981$. Assuming no costs and 


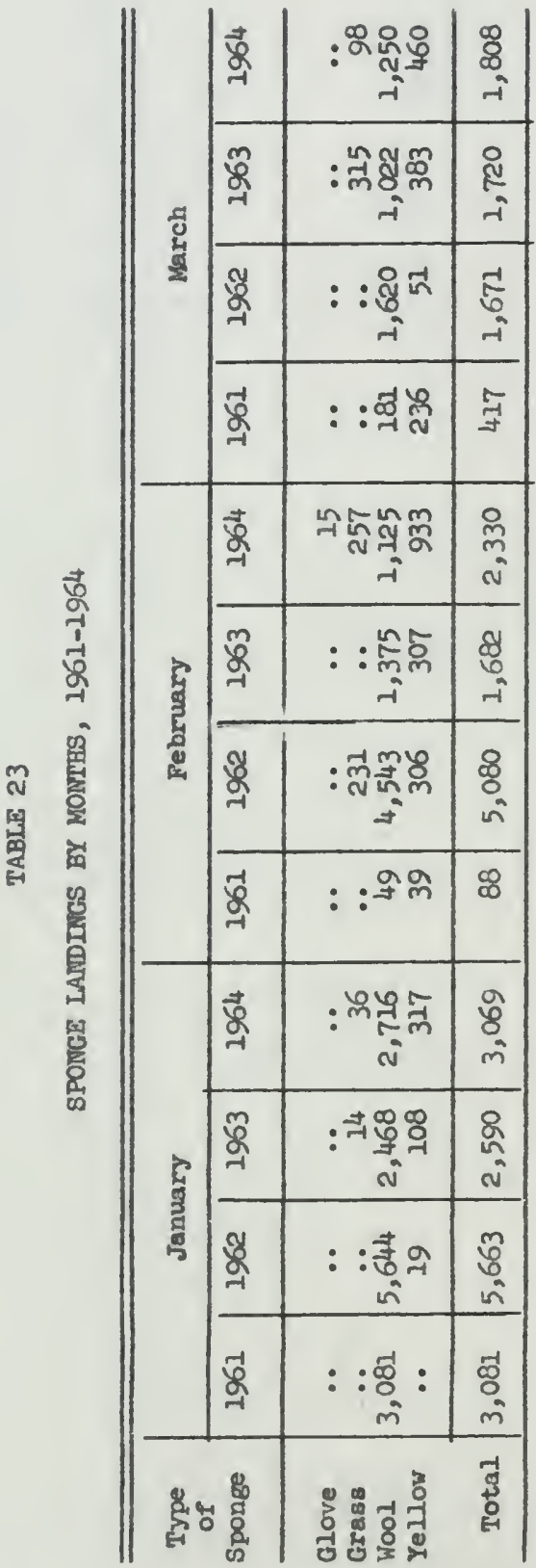

\begin{tabular}{|c|c|c|c|}
\hline \multirow{4}{*}{ ถู้ } & $\mathscr{H}_{-1}^{+}$ & : ${ }^{\infty}{ }_{m}^{\infty}$ & $\begin{array}{l}\mathscr{Y} \\
\text { ป }\end{array}$ \\
\hline & $\hat{\mathscr{R}}_{-1}^{m}$ & 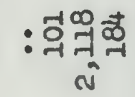 & no \\
\hline & ชू & 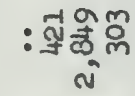 & in \\
\hline & हू & $:{ }_{m}^{\infty}$ & $\begin{array}{l}\text { जै } \\
\text { m } \\
\text { m }\end{array}$ \\
\hline \multirow{4}{*}{$\vec{a}$} & बे & $: 5 \mathrm{~J}^{5} \mathrm{~m}$ & $\begin{array}{l}5 \\
\text { n } \\
n\end{array}$ \\
\hline & $\stackrel{m}{8}$ & : ${ }_{m}^{\circ}$ & $\begin{array}{l}8 \\
\text { บ } \\
\text { d }\end{array}$ \\
\hline & 8 & : : ôm $^{n}$ & है \\
\hline & है & $:$ : in : & $\begin{array}{l}n \\
\text { nn } \\
\text { a }\end{array}$ \\
\hline \multirow{4}{*}{ 年 } & बै & : mญू్ & $\begin{array}{l}8 \\
\infty \\
\text { พ }\end{array}$ \\
\hline & है & 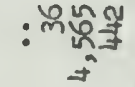 & $\begin{array}{l}m \\
\text { ठै } \\
\text { n }\end{array}$ \\
\hline & ชू & : : Rn & o \\
\hline & कू & $:$ : $\frac{a}{\text { ît }}$ & $\begin{array}{l}a \\
\text { a } \\
\text { ஸे }\end{array}$ \\
\hline हैं & $\frac{8}{8}$ & 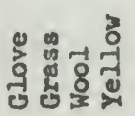 & 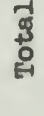 \\
\hline
\end{tabular}




\begin{tabular}{|c|c|c|c|}
\hline \multirow{4}{*}{ 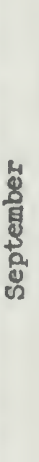 } & 屯্ & : قै & $\begin{array}{l}\not{\alpha} \\
\text { m }\end{array}$ \\
\hline & $\hat{\mathscr{g}}$ & 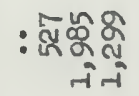 & $\begin{array}{l}-1 \\
\text { m }\end{array}$ \\
\hline & $\underset{-1}{8}$ & :58 & $\stackrel{m}{g}$ \\
\hline & 岳 & $: \begin{array}{c}-0 \\
-1 \\
-1\end{array}$ & $\begin{array}{l}\infty \\
\text { H-1 } \\
-1\end{array}$ \\
\hline \multirow{4}{*}{ 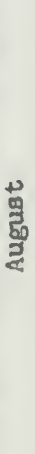 } & $\underset{-1}{\overrightarrow{8}}$ & 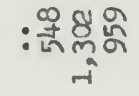 & is \\
\hline & $\underset{\gamma}{\tilde{r}}$ & बưñ & $\stackrel{5}{=}$ \\
\hline & $\begin{array}{l}8 \\
8 \\
-1\end{array}$ & $:$ : & ర్య \\
\hline & $\underset{-1}{-1}$ & : ल & $\stackrel{M}{N}$ \\
\hline \multirow{4}{*}{ ก } & $\frac{7}{8}$ & 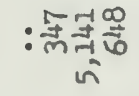 & लै \\
\hline & $\underset{\gamma}{\tilde{8}}$ & : ले नूहै & त्- \\
\hline & ช్- & : ம5 & कै \\
\hline & $\frac{-1}{8}$ & 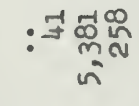 & $\begin{array}{l}8 \\
0 \\
\text { n }\end{array}$ \\
\hline \multicolumn{2}{|c|}{ 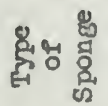 } & $\begin{array}{l}0 \\
0 \\
0 \\
0 \\
0 \\
0 \\
0\end{array}$ & 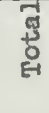 \\
\hline
\end{tabular}

\begin{tabular}{|c|c|c|c|}
\hline \multirow{4}{*}{ 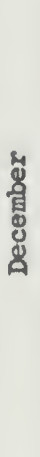 } & \& & $::::$ & : \\
\hline & $\underset{-1}{m}$ & : 어요 & 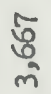 \\
\hline & 8 & 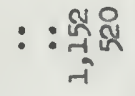 & సู \\
\hline & 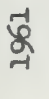 & : $\int_{-1}^{5} \frac{0}{5}$ & $\sum_{-1}^{\infty}$ \\
\hline \multirow{4}{*}{ 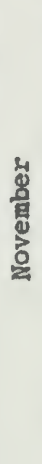 } & $\begin{array}{l}\overrightarrow{\vec{~}} \\
\text { ने }\end{array}$ & $::::$ & : \\
\hline & $\hat{\beta}$ & : & $\begin{array}{l}8 \\
\text { b } \\
m\end{array}$ \\
\hline & $\begin{array}{l}8 \\
8 \\
\text { \& }\end{array}$ & $::^{-1} \cong$ & $\underset{j}{m}$ \\
\hline & है & $:: \stackrel{n}{n}_{n}^{n}$ & ñ \\
\hline \multirow{4}{*}{$\begin{array}{l}\frac{4}{8} \\
\frac{\$}{8} \\
8\end{array}$} & $\underset{-1}{\overrightarrow{8}}$ & 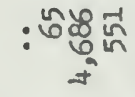 & ñ \\
\hline & $\mathscr{m}_{-1}^{m}$ & : लَळ & $\begin{array}{l}\text { ळ } \\
+\end{array}$ \\
\hline & $\underset{\gamma}{8}$ & 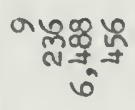 & $\begin{array}{l}8 \\
\text { d } \\
-1\end{array}$ \\
\hline & $\stackrel{\not h}{8}$ & : = $\begin{array}{c}\text { - } 5 \text { कू } \\
\text { n }\end{array}$ & 莡 \\
\hline \multicolumn{2}{|c|}{ हैं है } & 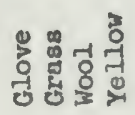 & $\begin{array}{l}7 \\
+3 \\
0 \\
0\end{array}$ \\
\hline
\end{tabular}


TABLE 24

AVRRAGE PRICE PER POUND RECEIVED BY SPONGE FISHERMEN AND BY FISHERMEN IN THE UNTHED STATES, 1946-I962

\begin{tabular}{|c|c|c|}
\hline & $\begin{array}{l}\text { Prices Recelved } \\
\text { By Sponge Flahermen }\end{array}$ & $\begin{array}{l}\text { Prices Recelved } \\
\text { By Fishermen }\end{array}$ \\
\hline & Dollars & Cents \\
\hline 1946 & 15.99 & 7.01 \\
\hline 1947 & 10.55 & 7.16 \\
\hline 1948 & 6.26 & 8.22 \\
\hline 1949 & 6.85 & 7.13 \\
\hline 1950 & 5.93 & 7.09 \\
\hline 1951 & 7.00 & 8.23 \\
\hline 1952 & 5.68 & 8.20 \\
\hline 1953 & 7.39 & 7.94 \\
\hline 1954 & 7.89 & 7.55 \\
\hline 1955 & $7 \cdot 32$ & 7.05 \\
\hline 1956 & 8.16 & 7.08 \\
\hline 1957 & 5.52 & $7 \cdot 39$ \\
\hline 1958 & 7.28 & 7.86 \\
\hline 1959 & 10.61 & 6.76 \\
\hline 1960 & 8.30 & 7.15 \\
\hline 1961 & 9.94 & 6.98 \\
\hline 1962 & 8.66 & 7.40 \\
\hline
\end{tabular}

Source: U. S., Bureau of Comerclal F1sherles, Un1ted States Fisherles, 1962. 
divlaing the value of total landings per hooking craft among 2.5 shares, with each flsherman recelving one share and one half share going to the boat, the average annual wage in sponge hooking was $\$ 268.80$. This figure is considerably lower than the median income of Pishermen in the state and explains why many people in hooking outfits have additional jobs.

In 1960 , the value of the average landings per diving craft was $\$ 21,966$ (see Table 15). Although 1t is not possible to obtain operatIng expenses for 1960 , assuming that they were similar to those of 1963, earnings avallable for distribution after the deduction of operating expenses amounted to $\$ 17,632$. The earnings per share amounted to $\$ 1,469.33$ with divers recelving an annusl wage of $\$ 2,938.66$, englneers and lifeline tenders an annual wage of $\$ 2,204$, and deck hands and cooks a wage of $\$ 1,469.33$.

The above calculations indicate that with the exception of hooking earnings in the sponge flsherles compare favorably with earnIngs in other types of fisherles. Divers, engineers, and lifeline tenders had incomes above the median earnings of fishermen. Even the least skilled person, such as a deck hand, earned more in machine diving than a relatively skilled worker did in hooking, primarily due to the higher capital labor ratio in mane diving.

It is interesting to note that higher than average earnings in diving have not induced aditional flshermen to enter this activity. Evidently the higher earnings recelved by divera are not high enough to compensate for the risks involved in this occupation. Also, fishermen with low earnings often can find superfor opportunities in other industries which may employ labor more productively than machine diving. 
THE MARKEWTING OF NATURAL SPONGES

From the very Inception of the sponge Pisheries in the United States sponges have been sold at auction. ${ }^{1}$ The Implications of the auction procedure are discussed later in this chapter. At Key West, which retained 1ts monopoly of the sponge trade unt1l 1895, a wharf was set apart as a sponge market w1th the buyers paying a fee proportional to the1r purchases.?

By 1895, Tarpon Springs had developed into a large-scale sponge market, and by the turn of the century 1t had passed Key West in Importance. Before 1908 sponges were sold at Irregular t1mes at the various crawls in Tarpon Springs. This arrangersent was inconvenient for sponge buyers, as the crawls were several miles away from the c1ty and from each other. To obviate this difficulty sponge buyers, knom In the trade as packers, organized the Tarpon Springs Sponge Bxchange in 1908. ${ }^{3}$ The establishment of the Sponge Exchange, coupled with the development of achine diving and the discovery of the Bay Ground sponge beds, made the city of Tarpon Springs the capital of the sponge business in the United States.

$1_{\text {Stuart, p. } 35 \text {. }}$

2U. S., Congress, The Fish and Fisherles of the Cosstal Waters of Florida, p. 43.

$3_{\text {Stuart, pp. 35-75. }}$ 


\section{The Tarpon 3prings Sponge Exchange}

The Tarpon Springs Sponge Exchsnge is a shareholding company with all Its shares owned by 1 ts members. Over 90 per cent of the sponges produced in the United States are sold through the Sponge Exchange. Membership in the Sponge Exchange is a prerequisite for all purchasers who buy sponges through the Sponge Exchange. Theoretically, nonmembers can obtain sponges by purchnsing them through members, but no such practice has taken place for the past two decades. All local packers in Tarpon Springs hold membership in the Sponge Exchange.

\section{Organ1zation}

The Tarpon Springs Sponge Exchange has a seven-member directing counc1l wh1ch consists of a president, vice-president, secretarytreasurer, and four directors. These officers are elected by members annualiy on the third Tuesday in January. The Sponge Exchange has a constitution and by-laws which regulate all transactions taking place at the Exchange. In addition to the seven-member directing council the Sponge Exchange employs an auctioneer and a secretary, the latter on a part-time basis. ${ }^{2}$

\section{Operations}

The Tarpon Springs Sponge Exchange provides boat owners with storage facilities and Insures their product agalnst theft and f1re while in storage. There are over 100 cell-like cages on the premises of the Sponge Exchange where boat owners store the harvested sponges

${ }^{1}$ Interview with Louls Smitzes, June, 1964. 2 Ibid. 
from the time they are brought ashore unt1l they are sold to members of the Sponge Exchange.

Whenever sponges are avallable for sale the buylng and selling take place twice a week on Tuesday and Friday, except Good Friday. All auctions start promptly at 9:30 A. M. If on the auction day more than one boat owner wishes to sell the order of offers 18 determined by drawing a ballot.

A sponge auction is conducted in a rather sllent fashion with the buyers crltically examining the bunches of sponges for quality. Upon finlshing their examination buyers write on a plece of folded paper the highest price they will pay for a bunch of sponges. A definftion of this term wes given in Chapter III. The highest bidder Is awarded the sponges, provided the seller considers the amount satisfactory. Owners can refuse to sell at a price they consider too low. In such cases their sponges are auctioned later the same day or on the following day.

For the services provided, the Tarpon Springs Sponge Exchange charges the seller 2 per cent of the amount of bis total sales. 1 From such b1llings the Sponge Bxchange defrays the expenses that m1ght be reguired in promoting the interests of the 1ndustry. Owners, members of Greek church,are charged with an additional 0.5 per cent, and this amount 18 donsted to the treasury of the St. Nicholas Greek. Orthodox Church in Tarpon Springs.?

\section{${ }^{1}$ IbIa. \\ ${ }^{2}$ Ibid.}


Evaluation of operations

Since the Tarpon Springs Sponge Exchange was organized by the packers, most of its activities are geared toward furthering their 1nterests. The Exchange is in a position to assist fishermen in their operations through a more meaningful classification of landing flgures. For example, by classifylng landings by region it might be possible to predict depletion of sponge beds for the varlous fishing regions. Such information, coupled with some industry regulations, might be used to alrect flahermen to flsh in other reglons unt1l the depleted beds have a chance to replenish themselvea. Conservation of sponge beds can also be accomplished by classifylng landings as to the size of the caught species. Consistent catches of smaller specles may Indicate potential supply problems, since a systematic harvesting of young sponges will adversely affect the future of the sponge grounds. Tarpon Springs Sponge Exchange officials recognize the value of such Information, but they feel that it would be unrealistic to install such a system with the present personnel, which consists of an auctioneer and a part-time secretary, and they are financlally unable to employ more people. ${ }^{2}$

The Bxchange has concentrated most of its activities in the area of politics, and in 1963, it was instrumental in influencing the General Services Administration to purchase all its natural sponges from Tarpon Springs packers. 2 Prior to f1scal year 1963, the Federal Government bought most of Its natural sponges from distributors located

\section{${ }^{1}$ Ib1d.}

2Interview with Ceorge Arfaras, owner of George Arfaras Packing Flrm, Tarpon Springs, Fla., May 13, 1964. 
outside Florlda. 1 In the same year the Bxchange, primarily through political influence, played an important role in the enactment of a state law which directed all state agencles to purchase Floridaproduced sponges. This law, as explained in the next chapter, has falled to accomplish its objective.

At present the Tarpon Springs Sponge Bxchange is attempting to obtain the permission of the United States Immigration Service to import more divers from the Mediterranean. 2 This attitude is easily understandable, because the analysis of packer operations in the following paragraphs indicates that most packing firms are unable to obtain enough sponge volume to break even. Although importation of divers may alleviate packer problems in the short mu, the Exchange has not considered the long-run effect that such a pollcy might have on the earnings of sponge fishermen, sponge prices, and the ava11ability of sponge supplies. These matters will be dealt with in greater detail in the conclusions of this paper.

\section{Packers}

At the Tarpon Springs Sponge Exchange sponges are auctioned to business firms known in the trade a packers. All such firms are located in Tarpon Springs, and they are responsible for the creation and operation of the Exchange.

The process of sponge buying has been explained, but it should be noted here that the methods used by packers to determine the quality of a given bunch of sponges are completely sensory and

${ }^{1}$ Tb1d.

${ }^{2}$ Interview with Louis Smitzes, June, 1954. 
qualitative. The test methods used in quality determination are derlved from long years of experlence and depend on the use of sight, touch, and sme11. 1

Most of the information on packers was obtained through a survey conducted in the summer of 1964 among the eleven packing firms which were in operation during that period in Tarpon Springs, Florida. Although the survey covered the ent1re population of packers, due to susplcious att1tudes and a lack of records it was not possible to collect much meaningful information from these businessmen. An English translation of the originsl Greek interview gulde used in the survey 15 presented as Appendix B.

\section{Operations}

Natural sponges sold at the Bxchange to the peckers are for the most part devold of forelgn materlal, but they may contain some fragments of rock or dead shrimp. Also, the shape of sane of these sponges Is irregular or the slze too large to sult the requirements of buyers. At the packing house all forelgn particles are removed and any 1rregularitles on the surface of the sponge are sheared off by clippers known as "psalidistades" in the trade." packers estimate the waste from such clippings to average between 4 to 8 per cent of sponge purchases depending on the composition and quality of the purchased apecies. 3 For example, the Rock Island Wool sponges normally require less

IInterview w1th John Kouremetis, owner of John Kouremetis Packing Firm, Tarpon Springs, Fla., May 19, 1964.

\section{Io1d.} 1964.

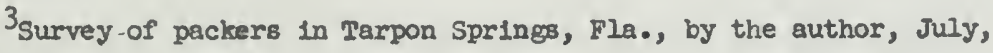


clipping as compared to Grass sponges whlch, because of their size and shape, demand extensive shearing before being offered to the market. In the past such waste was sold to manufacturers of roofing paper and steam pipe insulation. ${ }^{1}$ During the war when there was a shortage of sponges such trimenings were sold for 50 cents a pound. ${ }^{2}$ At present, packers are unable to dispose of such clippings and extreme care is exercised to reduce such waste to a minimum. ${ }^{3}$

After being carefully clipped sponges are separated by size and quality. The first step is to separate the sponges into two groups, "forms" and "cuts." 4 Forms are sponges in their whole natural shape. Cuts are sponges cut either from larger form sponges or from sponges that have been distorted by the clipping out of a diseased part or a crabhole. Cut sponges are further classifled into firsts, seconds, and thirds, depending on quality. These classifications are then assorted by size, the grading depending on the number of sponges required to make a pound. The sizes are ones, twos, twos to threes, threes to fours, fours to sixes, sixes to elghts, elghts to tens, tens to twelves, twelves to sixteens, and sixteens to twenties. The sizing is done by passing the specimens through standardized holes in a plece of veneer.

After having performed the above-mentioned functions packers sell the sponges to wholesale distributors located primarily in

\footnotetext{
$I_{\text {stuart, p. } 38 .}$

2Ib1a.
}

Intervlew with Mike Samarkos, owner of Samarkos Brothers, Inc., Tarpon Springs, Fla., May 20, 1964.

${ }^{4}$ Interview w1th Louls Smitzes, June, 1964. 
New York C1ty, Chicago, St. Louls, and Clnclnnat1, w1th New York C1ty being the most important market. ${ }^{I}$ It 18 known by the trade that some packers sell their products alrectly to users. All survered packers were aware of the existence of such selling, but none admitted dolng so himself because this 18 considered by the trade to be an unethical practice. The amount of sales outside the established distribution channels is not known, but in view of 1 ts clandestine nature one may assume that 1t could not be a large percentage of total packer sales. Also, because of their rather 11 mited flnanclal resources packers could not afford an aggressive selling policy.

Unt11 1951, packers sold sponges by welght. ${ }^{2}$ Because of the Ifmited supply of sponges and their high price packers gradually developed a practlce known as "loading" by which the weight of sponge shipments was increased through the addition of all kinds of forelgn materials to the species. 3 In later years this practice became so extravagant that at times up to 100 per cent welght was added by forelon waterials, which not only were difficult to insert into the sponge but had to be removed from it before 1t could be $801 d$ to the ultimate user. 4 In 1951, to obviate this unethical practice and under pressure from the Federal Trade Comission packers in Tarpon Springs resolved to sell sponges by plece 1nstead of welght. One may assume that loading had an adverse effect on sponge users, although it 18

IIb1a.

IIb1d.

3obert B. Bennett, Background Information for Voluntary Grade Standards on Natural Sponges, U. S. F18h and W1ldilfe Service Special Sclent1f1C Report, F1sher1es No. 273 (Washington: U. S. Government Printing office, 1958), p. 53.

${ }^{4}$ Tbid. 
impossible to measure the number of users who may have switched to substitute products. Distributors in New York City mentioned that their customers still examine sponges for rocks and other weightadding foreign matter. ${ }^{2}$

Packers sell sponges in burlap bales corded with jute rope and marked with a card glving the date, the kind and grade, the weight, and the number of pieces in each bale. The size of the bale depends on the number of pieces ordered by the distributors. It is customary for packers to sell F.O.B point of purchase with the distributor paying the freight charges and making his remittance in 60 days. Although bales shipped by packers are of no standard welght, packers indicated that orders of 250-300 pieces are the most frequently recelved. They estimated that the terial cost in packing such a shipment is approximately 50 cents. ${ }^{2}$

\section{Personnel}

Table 25 shows that most of the firms engaged in packing are 8mall family operations. The typical f1rm is managed by a rather elderly husband and wife team withthe children and other relatives assisting in the operations. As can be seen in Table 25 the ratio of relatives to non-relatives is high, indicating that such enterprises might not survive if they had to pay going wages for the performance of functions necessary to run the business. Because of their low profitability such firms have been unable to attract the type of personnel that could lead an enterprise to frow through exploring

IInterview with Robert Sinenberg, partner in Florida Sponge and Chamois Co., NeW York, November 18, 1964.

2Interview with George Arfaras, May, 1964. 
TABLE 25

TOTAL NUMBER OF FULL-TIME AND PART-TIME GMPLOYSES OF EILEVEN PACKING FIRMS IN TARPON SPRINGS, FLORIDA,

AND THEIR RELATIONSEIP TO THE OWNER

\begin{tabular}{|c|c|c|c|c|c|}
\hline \multirow{2}{*}{$\begin{array}{l}\text { Number } \\
\text { of Firms }\end{array}$} & \multicolumn{2}{|c|}{$\begin{array}{l}\text { Total Full-Time } \\
\text { Employees }\end{array}$} & \multicolumn{2}{|c|}{$\begin{array}{c}\text { Total Part-Time } \\
\text { Employees }\end{array}$} & \multirow{2}{*}{$\begin{array}{l}\text { Relatives as } \\
\text { a Percentage } \\
\text { of Full-Tim } \\
\text { Workers }\end{array}$} \\
\hline & Relatives & $\begin{array}{l}\text { Mon- } \\
\text { Relatives }\end{array}$ & Relatives & $\begin{array}{l}\text { Non- } \\
\text { Relatives }\end{array}$ & \\
\hline 1 & 1 & 3 & 2 & 0 & 25 \\
\hline 2 & 1 & 3 & 0 & 0 & 25 \\
\hline 3 & 2 & 0 & 2 & 0 & 100 \\
\hline 4 & 1 & 0 & 0 & 5 & 100 \\
\hline 5 & 1 & 1 & 1 & 0 & 50 \\
\hline 6 & 1 & 2 & 0 & 0 & $33 \cdot 3$ \\
\hline 7 & 1 & 1 & 2 & 0 & 50 \\
\hline 8 & 2 & 0 & 0 & 0 & 100 \\
\hline 9 & 2 & 0 & 0 & 0 & 100 \\
\hline 10 & 1 & 0 & 2 & 0 & 100 \\
\hline 11 & 2 & 0 & 1 & 0 & 100 \\
\hline
\end{tabular}

Source: Survey of packers in Tarpon Springs, Fla., by the author, July, 1964.

unexploited opportunities and reaching out for new markets. As a rule the owners of these establishments have shown little effort since the inception of their firms to change their operating procedures or try new methods in order to better serve their customers. The colum "Relatives" in Table 25 Includes the owner or owners of the enterprise, Inasmuch as, in addition to managing the enterprise, all owners perform non-managerial duties such as bookkeeping, cleaning the premises, and clipping sponges. Two of the surveyed firms employed clerfcal workers, one each, and only the two largest firms employed clippers on a full-time basis. The other firms perform this cllpping 
function by hiring help on a part-time basis or, as in the majority of cases, the clipping is done by the owners themselves. For example, a husband and wife team can trim a $\$ 10,000$ purchase consisting of approximately 1,00-1,200 sponges in about a week. ${ }^{2}$ Part-time clippers can always be found among the ranks of lale or retired fishermen, and they are pald on an hourly basis at a current hourly rate of $\$ 1.50 .2$

\section{Evaluation of operations}

In 1932 , there were iffteen flrms engaged in sponge packing in the city of Tarpon Springs, and in 1933, the number of such f1rms increased to sixteen. ${ }^{3}$ It is possible, although not likely, that a businessman would invest cspital in a fleld beset with supply and demand difficulties. Although this may be a highly speculative assumption the fact that an additional firm was aded in one year can be interpreted in terms of a favorable market outlook, which also Implies that no supply problems were anticipated at that time.

Between 1933 and 1963 sponge production declined by 83 per cent; however, for the same perlod the number of packing firms showed only a decline of 32 per cent. of the currently operational packing flrms none has been in this kind of business for less than 30 years. 4 Despite shrinking markets and a chronic shortage of sponges to sell, such firms try to malntain their image as sponge packers. At present, only three flrms are engaged in packing on the basis of selling sponges as a full-time activity. Most of the remalning firms derive

IInterview with Mike Samarkos, May, 1964.

2Interview with ceorge Arfaras, May, 1954.

3 sage, p. 3.

${ }^{4}$ Survey of packers in Tarpon Springs, Fla., by the author, July, 1964. 
TABLE 26

PACKER SALES BY IINE OF PRODUCT, 1963

\begin{tabular}{|c|c|c|c|c|c|}
\hline $\begin{array}{l}\text { Number } \\
\text { of } \\
\text { Flrms }\end{array}$ & $\begin{array}{l}\text { Sponge Sales as } \\
\text { a percentage or } \\
\text { Total Sales }\end{array}$ & $\begin{array}{l}\text { Souvenir Sales } \\
\text { as a Percentage } \\
\text { of Total Sales }\end{array}$ & $\begin{array}{l}\text { Brush } \\
\text { Manufac- } \\
\text { turing }\end{array}$ & $\begin{array}{l}\text { Real } \\
\text { Estate }\end{array}$ & $\begin{array}{l}\text { Leather } \\
\text { Processing }\end{array}$ \\
\hline 3 & 100 & $\cdots$ & .. & .. & $\cdots$ \\
\hline 1 & 20 & 10 & .. & .. & 70 \\
\hline 1 & .. & 20 & 80 & .. & .. \\
\hline 2 & 50 & 50 & .. & .. & .. \\
\hline 1 & 20 & 50 & .. & 30 & .. \\
\hline 2 & 30 & 70 & .. & .. & .. \\
\hline 1 & 20 & 80 & .. & .. & .. \\
\hline
\end{tabular}

Source: Survey of packers in Tarpon Springs, Fla., by the author, July, 1964.

better than three-fourths of their recelpts from activities shown on Table 26, but due to their emotional involvement such persons st1ll prefer to be called packers and do their best to reflect such an image.

The custorary markup of packers 1 a 25 per cent on the cost of purchases. ${ }^{2}$ As was polnted out previously, lack of record keeping among packers was such that no meaningful data could be developed. Of the three bona I1de packers the largest two are credited with buylng between 75 to 80 per cent of the annual sponge production for the past several years. Th1s $\mathrm{Plgure}$ was consistently mentloned by all peckers, Including the owners of the two enterprises dolng such buylng. Table 27 Indicates the financlal strength of the two largest packing firms as estimated by Dun and Bradstreet.

As w1ll be demonstrated in the followlng pages, w1th the present production of natural sponges most f1rms could not break even if they

IInterview w1th M1ke Samarkos, May, 1964. 
TABLE 27

FIMANCIAL STRENGTH OF ELEVEN SPONGE PACKLRS IN TARPON SPRINGS, FLORIDA, 1963

Total Assets

Number of Firms

$\begin{array}{cc}\$ 5,000-20,000 & 3 \\ 10,000-20,000 & 1 \\ 20,000-35,000 & 1 \\ 35,000-50,000 & 2 \\ 75,000-125,000 & 2 \\ \text { r.a. } & 2\end{array}$

Total Firms

11

Source: Dun and Bradstreet, Reference Book, 1964 (New York: Dun \& Bradstreet, 1964).

had to rely on the sales of sponges alone. While surveying the sponge industry in June and July of 1964, the author I1ved in a house owned by the owner of the f1rm which has been mentioned previously as the third IIrm engaged in full-scale packing. Due to such close association it was possible to obtain accurate data on expenses and propitability of an average size bona flde packer (see Table 28). The other two packIng IInas were very uncooperative in disclosing information concerning even rough approximations of expenses and other phases of their operat1ons. The financial strength of this establishment as estimated by Dun and Bradstreet is between $\$ 35,000-\$ 50,000$. The site of the business 18 owned by the owner; h1s annual purchases for 1963 were $\$ 39,963$, and his sales during the same year amounted to $\$ 50,983$. The owner performs all the needed functions except the cllpping of sponges which is done by part-time labor as the need arises. During 1963, $\$ 684$ 
was paid to clippers for trimming approximately 5,700 1bs. of sponges. I Based on these relationships the approximate cost of clipping one pound of sponges is about 12 cents. Packers mentioned that it takes $\$ 2.25$ worth of burlap and cord to make a bale weighing roughly 50 pounds which means that the average cost of packing one pound of sponges is approximately 4.5 cents. Of course, this average cost per pound may vary with the size of the bale, larger bales resulting in a lower cost per pound and smaller bales in a higher cost per pound. In view of the fact that this is the only information avallable on the cost of packing sponges and that most of the orders received by packers are for sizes welghing approximately 50 pounds, the 4.5 cents figure can be accepted as a crude approximation of the overall average cost. The cost for clipplng and packing one pound of sponges was 16.5 cents In 1963, and the total cost of performing these two functions for 5,700 pounds amounted to $\$ 940.50$. This figure, when added to total annual purchases of $\$ 39,963$ and then subtracted from annual sales of $\$ 50,983$, gives a gross profit of $\$ 10,079.50$ for the year 1963 , which represents a 25.22 per cent markup on cost. By dividing this markup of 25.22 per cent 1nto the total annual fixed expenses shown in Table 28 it is possible to approximate the breakeven point of this enterprise, wh1ch is $\$ 18,712$.

Th1s case study shows that the current level of sponge landings is not sufficlent to sustain the number of establishments presently

IThe average price per pound recelved by sponge fishermen in 1963 was $\$ 7.01$ (see Table 10). Since prices pald by packers are those recelved by the fishermen, dividing annual purchases of $\$ 39,963$ by the average price of $\$ 7.01$ gives a figure approximately equal to the welght of the purchased sponges. 
TABLE 28

SUMMARY OF OPERATIMG EXPENSES OF ONE PACKMIY FIRM FOR $1963^{2}$ Item

Anount

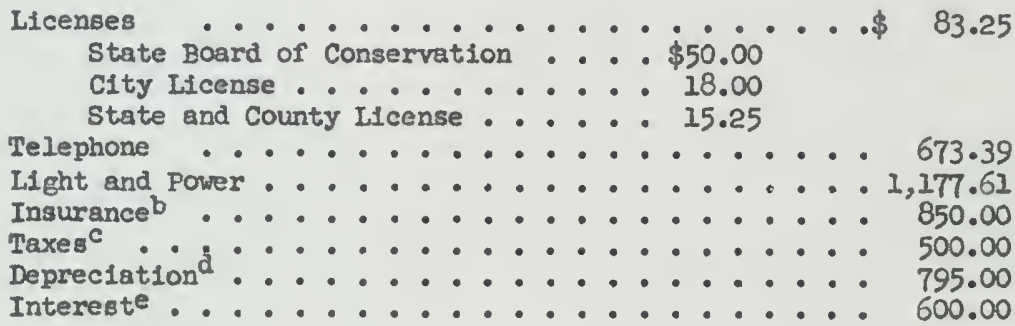

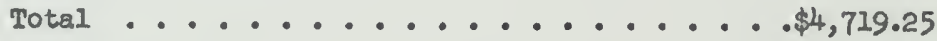

'Since the owner's residence and place of business are the same it was not possible to determine which part of the above expenses should be charged to the firm. All the expenses in the table are deducted from his taxes by the owner.

${ }^{b}$ Covers premises, equipment, and merchandise in storage.

'Property taxes.

$\mathrm{d}_{\text {Building and equipment. }}$

Implicit interest calculated at 6 per cent per annum on an average annual inventory of $\$ 10,000$. The owner does not make such calculations.

engaged in sponge packing. In 2963 , the three firms mentioned previously bought $\$ 330,408.75$ worth of sponges or 85 per cent of the total sponge landings for that year. Adaing a 25 per cent markup on $\$ 56,852.25$, which represents the 15 per cent of 1963 sponge landings not absorbed by the three firms, leaves a $\$ 71,065.31$ sales volume to be shared by the remalning eight packers. In view of the above case study of a single packer it is obvious that eight firms could not possibly operate and make a profit by sharing a sales volume of 
$\$ 71,065$. This situation supports the findings of the suthor in his complete canvass of packers in Tarpon Springs that elght of eleven packers had to carry other lines in order to spread their overhead cost over a larger volume of sales.

The exlstence of two large flrms buying more than three-fourths of the total annual production has undoubtedly profited the f1shermen at the expense of the packers. Few of the smaller packers have the financial strength to compete with the two large buyers on a price bas1s. It is the consensus of industry members that in the absence of such concentrated buylng sponge prices at the producers' level would be lower than they are today. ${ }^{1}$

Packers see increased production as the solution to their problem. At present, w1th the sponge beds having returned to a condition of normalcy the in obstacle to higher production is a shortage of diving personnel. During the past flve years packers have imported through their trade assoclation, the Tarpon Springs Sponge Exchange, fourteen divers from the Mediterranean, but all such divers have sought and found other jobs in the industrial cities of the North after enter Ing the United States. ${ }^{2}$ The Tarpon Springs Sponge Exchange has pet1tioned the Immigration and Naturalization Service for permission to Import twenty divers from the Mediterranean. It has decided that no diver younger than 45 years of age should be brought in because an older person with little or no knowledge of the English language will have a limited opportunity to find employment in other industries.

\footnotetext{
1964.

Isurvey of packers in Tarpon Springs, Fla., by the author, July,
}

2Interview with Louis Smitzes, July, 1964. 
All eleven packers agreed that unless sponge production is increased they will elther be forced out of business or be pushed into other types of activities. 1

It has been polnted out previously that between 1933 and 1963 sponge landings decreased by 83 per cent (see Table 10). Iet,we.1 1932 and 1953 the number of diving craft decreased from 51 to 13 , a decline of approximately 75 per cent, but for the same period the number of packing establishments showed a decrease of only 31 per cent. Such figures support the Implications of the analysis in the preceding paragraphs, that the packing level of the sponge Industry is overcrowded. The current level of sponge landings is not sufficient to austain the eleven firms in Tarpon Springs currently listed as packers. 2

\section{The Sponge and Chamols Institute}

The Sponge and Chamols Institute was founded in 1933 by the distributors and suppliers of natural sponges and real chamols. 3 As of November 1954, the Inst1tute had 24 nembers; $81 x$ of the members are located in foreign countrles, wlth the remaining elghteen scattered among nine states. More than 50 per cent of the domest1c distributors are located in or near New York C1ty, and the Sponge and Chamols Institute 1s located in Long Island, New York. Its staff consists of a president, an executive secretary, and a clerical worker. 4 1964.

Isurvey of packers in Tarpon Spring,8, Fla., by the author, ruly,

2Interview with Loula Smitzes, July, 1964.

3 Interview wlth Mrs. Ellzabeth Wallace, Exccutive Secretary, Sponge and Chamo1s Inst1tute, New York, November 16-20, 1964.

${ }^{4}$ Ibld. 


\section{Operations}

The Institute cooperates closely with the Tarpon Springs Sponge Exchange and varlous governmental sources in protecting and promoting the Interests of 1 ts members and the sponge industry at large. For example, the Institute participated in the sponsoring of the Farrisburg market experiment whlch w11l be discussed later in this chapter. In adition, the Institute Informs nember alstributors about sales trends, opportunit1es, and regulations through a regular semi-monthly publication, the Bulletin. ${ }^{1}$ Such data are based on information collected from members and varlous governmental agencies. Also, the Institute Issues various Prade Reports at irregular Intervals to inform 1ts members of urgent matters and unusual developments concerning the sponge and chamols business. ${ }^{2}$ Information developed by the Institute w11 be presented in subsequent analysis.

After obtaining a list of their customers from sponge packers in Tarpon Springs the author found that in addition to the elghteen distributors listed as members of the Sponge and Chamols Institute, Tarpon Springs packers sold to seven other distributors who were not members of the Institute. 3 Since--barring clandestine sales and imports--packers are the only source for purchasing domestically produced sponges, it can be seen that approximately 82 per cent of the sponge distributors in the United States are members of the Sponge and Chamols Institute. This indicates that statistics provided by

$I_{\text {Ibid. }}$

Irbid. 1964.

${ }^{3}$ Survey of packers in Tarpon Springs, Fla., by the author, July, 
the Institute are of considerable value for the following reasons. (1) Data provided by the Institute constitute the only available Information on sponge sales at the distributor level. (2) A large number of distributors hold membership in the Institute and cooperate with it in the collection of statistical data. (3) Non-member distributors constitute a small percentage of the total distributor population and are responsible for an even smaller percentage of total sponge transactions at the distributor level. officials of the Sponge and Chamois Institute estimate that non-member sales constitute less than 2 per cent of total distributor sponge sales. ${ }^{1}$ (4) AII known chamols distributors are members of the Institute. As w1ll be pointed out in discussing distributors, sponge and chamois are products of a complementary nature. In order to be successful as a sponge distributor a firm has to include both items in its product $\operatorname{mix}$.

\section{Evaluation of operations}

The only natural sponge statist1cs ava1lable at the distributor level are those gathered by the Sponge and Chamois Institute. The Institute complles annual figures of natural sponge sales and chamois sales as reported by 1 ts members. 2 It also complies statistics on total natural sponge imports from data published by the Bureau of Census. 3

Interview with Mrs. Elizabeth Willace, November, 1964. 2 Ib1d. 3 Ibld. 
In spite of 1ts Iimited staff and facilities the Institute does a remarkable job, but there is much room for improvement. For example, it would be very helpful to know sales by type of customer of the distributor in order to get a better picture of sales trends. At present, no such f1gures are kept by the Institute, primarliy because members object to excessive paperwork. Mrs. Ellzabeth Wallace, Executive Secretary of the Inst1tute, is currently attempting to persuade members of the value of reporting such information which might be useful for conducting their affairs more efficlently. ${ }^{l}$

\section{Distributors}

Distributors constitute the next link in the marketing of natural sponges. In 1964, there were eifhteen natural sponge distributors in the United States. Most sponge distributors are located in and around ports on the eastern Atlantic coast. ${ }^{2}$ This is a natural development since, as can be seen in Table 29, imports have always constituted a rather large percentage of the total natural sponge supplies in the United States. Most of the information on distributors was obtained from records supplied by the Sponge and Chamois Institute and by interviewing the owners of $s 1 x$ flrms located in the states of New York and New Jersey. According to Mrs. Elizabeth Wallace, these six firms are responsible for better than 80 per cent of the sponge sales at the distributor level. Two attempts to obtain information from all knowa distributors produced no response.

IIb1d.

?. Io1d. 
TABLE 29

DOMESTIC AND IMPORTED SPONGES AS A PERCEATIAGE OF TOTAL SUPPLY $1934-1963$

\begin{tabular}{|c|c|c|c|c|c|c|}
\hline \multirow{3}{*}{ Year } & \multicolumn{2}{|c|}{ Domestic } & \multicolumn{2}{|c|}{ Imports } & \multirow{2}{*}{\multicolumn{2}{|c|}{ Total }} \\
\hline & \multicolumn{2}{|c|}{ Pex Cent of Total } & \multicolumn{2}{|c|}{ Per cent of Total } & & \\
\hline & Quantity & Value & Quant1ty & Value & Quant1ty & Value \\
\hline 1934 & 50.30 & 63.06 & 49.70 & 36.94 & 100.00 & 100.00 \\
\hline 1935 & 37.76 & 56.83 & 62.24 & 43.17 & 100.00 & 100.00 \\
\hline 1936 & 50.42 & 64.69 & 49.58 & 35.31 & 100.00 & 200.00 \\
\hline 1937 & 48.41 & 64.87 & 51.59 & 35.13 & 100.00 & 100.00 \\
\hline 1938 & 54.86 & 51.05 & 45.14 & 38.95 & 100.00 & 100.00 \\
\hline 1939 & 48.66 & 68.16 & 52.34 & 31.74 & 100.00 & 100.00 \\
\hline 1940 & 30.80 & 58.96 & 69.20 & 41.04 & 100.00 & 100.00 \\
\hline 1941 & 47.50 & 72.47 & 52.50 & 27.53 & 100.00 & 100.00 \\
\hline 1942 & 61.02 & 73.48 & 38.98 & 26.52 & 100.00 & 100.00 \\
\hline 1943 & 48.85 & 71.71 & 51.15 & 28.29 & 100.00 & 100.00 \\
\hline 1944 & 60.84 & 72.95 & 39.16 & 27.05 & 100.00 & 100.00 \\
\hline 1945 & 66.99 & 77.43 & 33.01 & 22.57 & 100.00 & 100.00 \\
\hline 1946 & 33.04 & 45.62 & 66.96 & $54 \cdot 38$ & 100.00 & 100.00 \\
\hline 1947 & 36.12 & 42.64 & 63.88 & $57 \cdot 36$ & 100.00 & 100.00 \\
\hline 1948 & $17 \cdot 34$ & 15.26 & 82.66 & 84.74 & 100.00 & 100.00 \\
\hline 1949 & 22.11 & 19.55 & 77.89 & 80.45 & 100.00 & 100.00 \\
\hline 1950 & 6.18 & 5.19 & 93.82 & 94.71 & 100.00 & 100.00 \\
\hline 1951 & 5.90 & 4.92 & 94.10 & 95.08 & 100.00 & 100.00 \\
\hline 1952 & $12 \cdot 31$ & 10.22 & 87.69 & 89.78 & 100.00 & 100.00 \\
\hline 1953 & 6.28 & 7.28 & 93.72 & 92.72 & 100.00 & 100.00 \\
\hline 1954 & 7.27 & 9.59 & 92.73 & 90.41 & 100.00 & 100.00 \\
\hline 1955 & 13.69 & 15.15 & 86.31 & 84.85 & 100.00 & 100.00 \\
\hline 1956 & 21.98 & 15.76 & 88.08 & 84.24 & 100.00 & 100.00 \\
\hline 1957 & 15.69 & 14.75 & 84.31 & 85.25 & 100.00 & 200.00 \\
\hline 1958 & 13.37 & 13.77 & 86.63 & 86.23 & 100.00 & 100.00 \\
\hline 1959 & 14.42 & 19.18 & 85.58 & 80.82 & 100.00 & 100.00 \\
\hline 1960 & 16.67 & 19.81 & $83 \cdot 33$ & 80.19 & 100.00 & 100.00 \\
\hline 1961 & 27.47 & 31.10 & 72.53 & 68.90 & 100.00 & 100.00 \\
\hline 1962 & 34.22 & 33.17 & 65.78 & 66.83 & 100.00 & 100.00 \\
\hline 1963 & 39.99 & 32.48 & 60.01 & 67.52 & 100.00 & 100.00 \\
\hline
\end{tabular}

Source: Based on Table 40. 
In addition to marine sponges, distributors deal in chamois, a product which is used in cleaning, drylng, and polishing surfaces. This product is used in confunction with sponges under most circumstances and is of a conplementary nature. During the last decade natural sponge distributors have begun to sell synthetic sponges, a substitute product. Table 30 shows distributor sales since 1951 by line of product. Intermittent supplies of natural sponges coupled with high prices forced all distributors toward substitute products, that is, syntbetic sponges under private brand names. By selling a large number of units of synthetic sponges at lower prices, distributors heve been able to increase the sales volume of the complementary product mentioned previously. This strategy has enabled these firms to increase their total sajes volume and make a handsome profit through an acceleratedtumover of the complementary good bearing a high markap. This can be better understood through an examination of the data presented in Table 31.

In 1953 , naturel sponge s8.les contributed 39.69 per cent to the distributors' total sales volume. The contribution of the complementary product, chamois, was 60.31 per cent (again see Table 31). Ten years later in 1963, the contribution of natural sponges to total sales volume had fallen to 12.97 per cent while that of the complementary product increased to 71.92 per cent. Between 1953 and 1963 natural sponge prices were relatively stable, both at the producers' and distributors' levels (again see Table 10). The same held true for chamols prices for the same span of time. Since prices were stable Inid. 
between 1953 and 1963, a drop in percentage contribution to total sales volume indicates that fewer units of natural sponges vere sold in 1963. The reverse is true in the case of chamois. Chamols ssles as a percentage of total sales incressed by 21.61 per cent in ten years. Since there were no price incresses durlng that perlod this indicates that more physical units of chamols were sold in 1963 than were sold ten years ago. The expansion in chamols sales is due primarily to an increase in synthet1c sponge sales. In 1963 , synthetic sponge sales were only 15.11 per cent of the distributors' total sales volume. Th1s $1 \mathrm{~s} 11.61$ per cent less than the natural sponge sales of all distributors in 1953, but because of the low perunit price of synthet1c sponges, it represents an incresse in the physical units sold of the absorbing material. Since chamols is a complementary good to any absorbing material, an increase in the Bales volume of synthetic sponges has resulted in a higher sales volume for chamols.

\section{Operations}

Distributors obtain their supplies of natural sponges from packers in Taxpon Springs and various forelgn countries, primarliy Greece. The customary method for domest1c purchases is F.O.B. point of origin. Imports are handled on a C.I.F. point of destinstion basis. Distributors contact potential buyers through the use of the telephone and travelling salesmen, depending on the size of the firm. Since most buyers are located in and around New York City most selling is done via the telephone. I Only four of the largest alstributors indicated the use of salesmen.

\footnotetext{
IInterview w1th Robert Sinenber8, November, 1964.
} 
TABLE 30

SALBS IN DOLLARS OF NATURAL SPONGES, SYNMETIC SPONGES, AND CHAMOIS AT THE DISTRIBUTOR LEVEI, 1951-1964

\begin{tabular}{lcccc} 
Year & $\begin{array}{c}\text { Natural } \\
\text { Sponges }\end{array}$ & $\begin{array}{c}\text { Synthetic } \\
\text { Sponges }\end{array}$ & Chamo1s & Total \\
\hline 1951 & $2,951,970$ & $\ldots$ & $4,602,427$ & $7,559,397$ \\
1952 & $2,516,379$ & $\ldots$ & $3,749,342$ & $6,265,721$ \\
1953 & $2,402,223$ & $\ldots$ & $3,649,742$ & $6,051,965$ \\
1954 & $2,140,721$ & $\ldots$ & $3,281,171$ & $5,421,892$ \\
1955 & $2,294,874$ & $\ldots$ & $3,627,368$ & $5,922,242$ \\
1956 & $2,413,700$ & $\ldots$ & $3,445,089$ & $5,858,789$ \\
1957 & $2,241,033$ & $\ldots$ & $3,207,861$ & $5,448,894$ \\
1958 & $2,055,089$ & $\ldots$ & $2,804,320$ & $4,859,409$ \\
1959 & $1,919,958$ & $\ldots 9$ & $3,059,791$ & $4,979,749$ \\
1960 & $1,665,127$ & $1,142,874$ & $3,245,136$ & $5,054,137$ \\
1961 & $1,336,254$ & $1,275,789$ & $2,998,395$ & $5,610,438$ \\
1962 & $1,639,144$ & $1,409,652$ & $6,153,022$ & $9,202,618$ \\
1963 & $1,207,051$ & $1,406,332$ & $6,692,352$ & $9,306,235$ \\
$1964^{\circ}$ & 773,622 & $1,245,722$ & $3,965,661$ & $5,985,005$ \\
& & & & \\
\hline
\end{tabular}

Source: Sponge and Chamois Inst1tute records (In the files of the Institute).

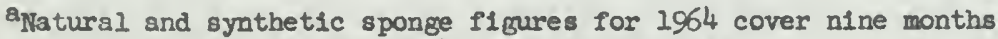
only, and chamols flgures for 1964 cover six months.

Table 32 shows distributor sales of natural and synthet1c sponges as reported by distributors to the Sponge and Chamois Institute. No such data are available for the years prior to 1962, but a comparison of the svallable flgures for two years shows that syathetic sponges have gained ground in all these deslgmated categories. The category "Trade" appears to be the most profitable outlet for natural sponges, since more than 90 per cent of the natural sponge sales were absorbed by this market. This broad category of "Trade" consists of wholesalers and jobbers catering to the needs of the fanitorial, paint, ceramic, automotive, and I1thographic trades. lot a single firm among natural 
TABIE 31

DISTRIBUTOR SALES OF NATURAL SPONGBS, SYNTHETIC SPONGES, AND CHMOIS AS A PERCENTAGE OF TOTAL SALES, $1951-1964$

\begin{tabular}{|c|c|c|c|c|}
\hline Year & $\begin{array}{l}\text { Natural } \\
\text { Sponges }\end{array}$ & $\begin{array}{c}\text { Symthet1c } \\
\text { Sponges }\end{array}$ & Chamo1s & Total \\
\hline $\begin{array}{l}1951 \\
1952 \\
1953 \\
1954 \\
1955 \\
1956 \\
1957 \\
1958 \\
1959 \\
1960 \\
1961 \\
1962 \\
1963\end{array}$ & $\begin{array}{l}39.05 \\
40.16 \\
39.69 \\
39.48 \\
38.75 \\
41.20 \\
41.19 \\
42.29 \\
38.56 \\
27.52 \\
23.82 \\
17.81 \\
12.97\end{array}$ & 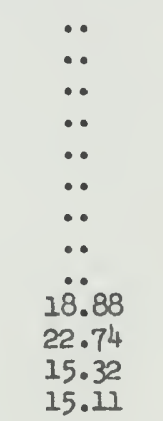 & $\begin{array}{l}50.95 \\
59.84 \\
60.31 \\
60.52 \\
61.25 \\
58.80 \\
58.81 \\
57.71 \\
61.44 \\
53.60 \\
53.44 \\
65.87 \\
71.92\end{array}$ & $\begin{array}{l}100.00 \\
100.00 \\
100.00 \\
100.00 \\
100.00 \\
100.00 \\
100.00 \\
100.00 \\
100.00 \\
100.00 \\
100.00 \\
100.00 \\
100.00\end{array}$ \\
\hline
\end{tabular}

Source: Based on Table 30.

TARLE 32

DISTRIBUTOR SALES OF NATURAL SPONGBS BY TYPE OF CUSTOMER, 1962-1964

\begin{tabular}{|c|c|c|c|c|c|}
\hline \multirow{2}{*}{ Year } & \multicolumn{2}{|c|}{ To Trade } & \multicolumn{2}{|c|}{ Inst1tut1onal } & Federal Government \\
\hline & NaturaI & Synthet1c & Natural & Synthet1c & Natural Synthetic \\
\hline $\begin{array}{l}1962 \\
1963 \\
1964^{b}\end{array}$ & $\begin{array}{r}\$ 1,346,808 \\
1,081,256 \\
685,431\end{array}$ & $\begin{array}{r}\$ 1,192,970 \\
1,159,423 \\
1,116,711\end{array}$ & $\begin{array}{r}\$ 270,758 \\
105,158 \\
65,868\end{array}$ & $\begin{array}{r}\$ 18,937 \\
43,551 \\
28,731\end{array}$ & $\begin{array}{cc}\$ 21,578 & \$ 190,773 \\
1,519^{\mathrm{a}} & 203,858 \\
\ldots & 100,217\end{array}$ \\
\hline
\end{tabular}

Source: Sponge and Chamols Inst1tute records.

after June, 1963, the Federal Covernment started purchasing 1ts natural sponges directly from the lowest bidder among packers in Tarpon Springs.

$b_{1964}$ 11gures are for nine months. 
TABLE 33

DISTRIBUTOR SALES OF IATURAL SPONGES TO TRADE CUSTOMERS Type of Customer Per Cent of Total Sales

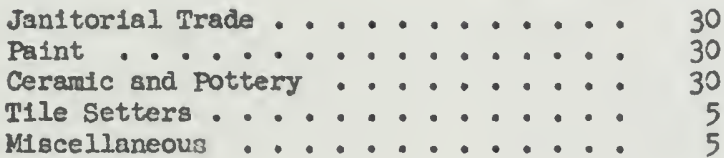

Total ............... 100

Source: Based on a survey conducted by the Sponge and Chamols Inst1tute, 1964.

sponge distributors keeps records showing natural sponge sales by type of customer within the three broadly designated categories of "Mrade," "Institut1onal," and "Government" (agaln see Table 32 ). W1th the encouragement and cooperation of the author an attempt was made by the Sponge and Chamois Institute to obtain a classification of sales by a finer breskdown of customer type. The results of this survey are shown in Table 33 and are based on the opinions and educated guesses of $s i x$ members of the Inst1tute. The remaining members either could not furnlsh any Information or refused to do so.

All distributors interviewed by the author have Indicated a preference for imports over domestically produced natural sponges. The reasons for th1s preference follow. (1) In general, forelgn producers have proved to be a more rellable source of supply than the domestic sources. Had it not been for imports, especially those from the Mediterranean, all users of natural sponges would have shtfted to synthetics during the scute shortages of sponges which followed the blights of 1937 and $1941 . .^{1}$ (2) Usually distributors have to clean

IInterview with Edward Riley, November, 1964. 

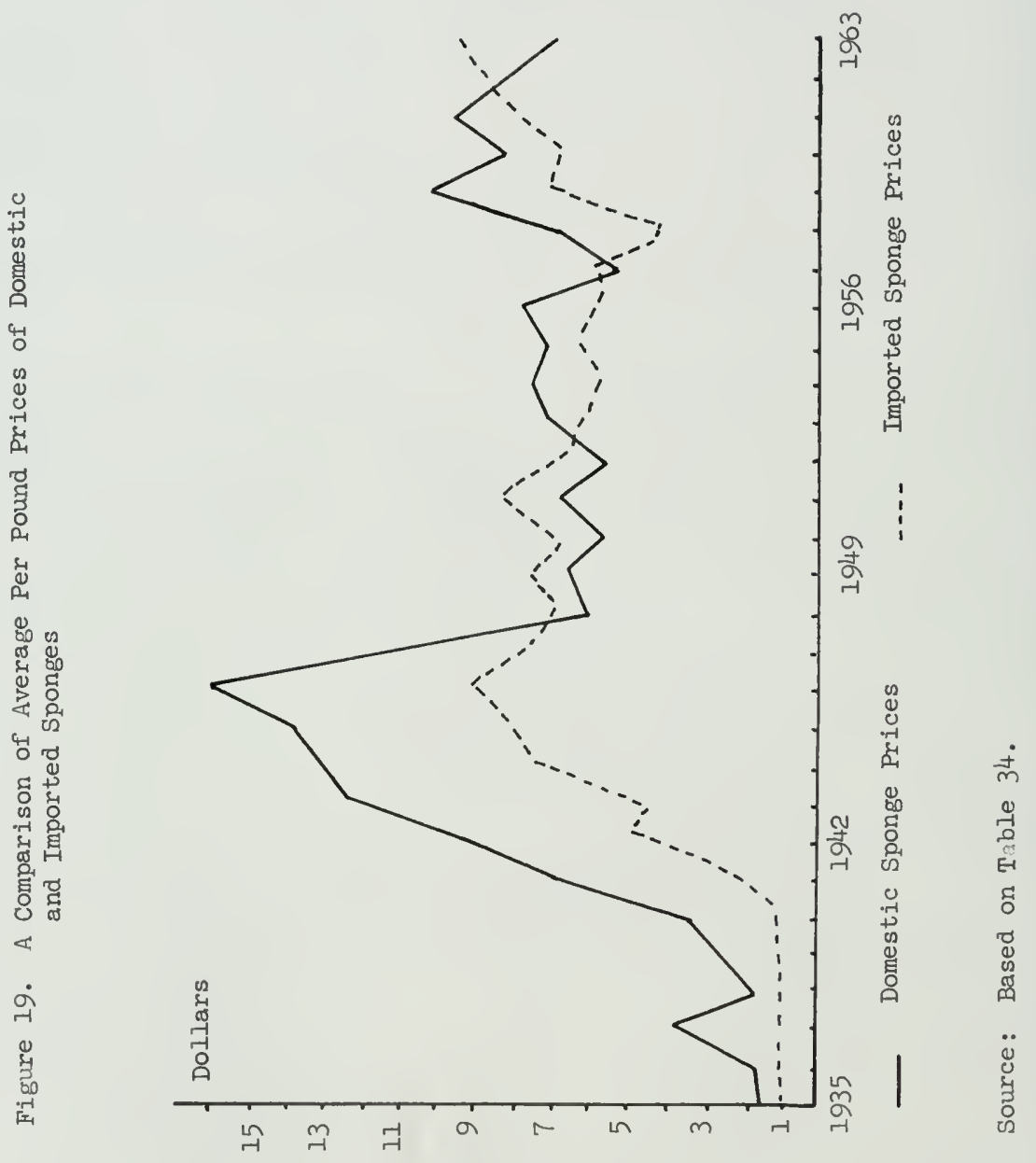
TABLE 34

A COMPARISON OF AVERAGE PER POUND PRICES

OF DOMESTIC AND IMPORTED SPONCES $1934-1963$

\begin{tabular}{|c|c|c|}
\hline \multirow{2}{*}{ Year } & \multicolumn{2}{|c|}{ Price Per Pound In Dollars } \\
\hline & Domest1c Sponges & Iuported Sponges \\
\hline $\begin{array}{l}1934 \\
1935 \\
1936 \\
1937 \\
1938 \\
1939 \\
1940 \\
1941 \\
1942 \\
1943 \\
1944 \\
1945 \\
1946 \\
1947 \\
1948 \\
1949 \\
1950 \\
1951 \\
1952 \\
1953 \\
1954 \\
1955 \\
1956 \\
1957 \\
1958 \\
1959 \\
1960 \\
1961 \\
1962 \\
1963\end{array}$ & $\begin{array}{r}1.36 \\
1.64 \\
1.67 \\
3.82 \\
1.43 \\
2.49 \\
3.66 \\
6.79 \\
9.24 \\
12.39 \\
13.27 \\
14.00 \\
15.99 \\
10.55 \\
6.26 \\
6.85 \\
5.93 \\
7.00 \\
5.68 \\
7.39 \\
7.89 \\
7.32 \\
8.16 \\
5.52 \\
7.28 \\
10.61 \\
8.30 \\
9.94 \\
8.66 \\
7.01\end{array}$ & $\begin{array}{l}.81 \\
.76 \\
.93 \\
1.00 \\
1.11 \\
1.11 \\
1.13 \\
2.33 \\
5.22 \\
4.67 \\
7.64 \\
8.29 \\
9.40 \\
8.03 \\
7.29 \\
7.75 \\
6.91 \\
8.41 \\
6.85 \\
6.38 \\
5.87 \\
6.20 \\
5.94 \\
5.94 \\
7.01 \\
7.53 \\
6.72 \\
8.34 \\
9.08 \\
9.71\end{array}$ \\
\hline
\end{tabular}

Source: Based on Table 10 and Table 40. 
and wash Florlda sponges, because this process is often neglected or done very superficially in Tarpon Springs. I Thts washing and drying process obviously adds to the cost of the sponges and has an adverse effect on distributors' prof1ts. No cleaning and washing is needed with imported sponges, a factor which makes them more desirable from a distributor's point of view. ${ }^{2}$ (3) As can be seen in Figure 19, with few exceptions average prices of inported sponges have always been lower than average prices of domestic sponges. As a matter of fact, the price differences are larger than those indicated, because Flgure 19 compares average domestic prices obtained by f1shermen with average import prices pald by distributors. Adding packer maxkups and transportation costs from Tarpon Springs to distributor locations w1ll obviously raise domestic sponge prices considerably at the distributor's level. (4) Although most users ask for Florlda Rock Island aponges, distributors state that the jority of them could not tell the difference between Florida and imported sponges. ${ }^{3}$ Distributors substantiate this contention by the fact that in order to avold losing customers because of price increases they simply hold the price line by offering imported sponges as Florida sponges. ${ }^{4}$ (5) Since most users cannot tell the difference between domest1c and Imported sponges, distributors can and do sell low-cost imported products at the same price as the domest1c product. A higher markup on Imports glves distributors an incentive to carry them and push them more agressively.

IInterview with Robert Sinenberg, November, 1964.

${ }^{2}$ Iold.

${ }^{3}$ Iold.

${ }^{4}$ Ib1d. 
TABLE 35

FINANCIAL STRERGTH OF NATURAL SPONGE DISTRIBUTORS

WHO ARE MPMBERS OF THE SPONGE AND

CHAMOIS INSTIIUTE, 1964

Total Assets

Number of Firms ${ }^{8}$

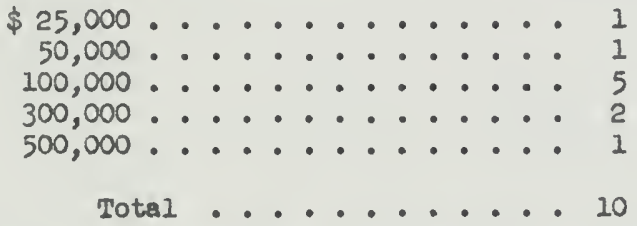

Source: Thomas' Reglster of Manufacturers, 1964 (New York: Thomas Publishing Co., 1964).

$a_{\text {EI ght member }}$ I1rms and the other seven customers buylng from the packers but who were not members of the Sponge and Chamols Institute were not listed in Thomas' Reglster.

\section{Facilities}

Table 35 shows the financial strength of ten sponge distributors as reported in the 1964 edition of the Thomas Register of Manufacturers. The median fixin in 1964 had total assets of $\$ 100,000$, which 1s considerably blgher than the assets of the median packer (again see Table 27) or producer of natural sponges. This financial strength coupled with more sophisticated management has placed the distributors in a position of channel leaders in the distribution of natural sponges. Unlike packers in Tarpon Springs, who are mostly order takers from distributors, distributors attempt to reach and enlarge their markets through more sophisticated marketing techniques. For example, the Sponge and Chamols Institute was instrumental in developing a fourteen-mirute film entitled "Sponge - Treasure of the Sea," wh1ch has been f1lmed in cooperation with the Bureau of Commerclal Fisherles. This film has 
been shown to televisfon and theater audiences in the United States in order to acquaint them with natural sponges and arouse their interest. 1 The Harrisburg test market which was conducted in 1963 was also promoted by the Sponge and Chamois Institute in order to sell more natural sponges to ultimate consumers. ${ }^{2}$ The results of this experiment will be described in Chapter VI.

Distributor premises include warehouses, bleaching fac1litles, and various machines for the cutting and packaging of synthetic sponge blocks. Chapter $V$ gives a more detailed account of syathetic sponges handled by natural eponge distributors. The number of personnel employed by distributors differs widely depending on financial size and diversity of operations. For example, American Sponge and Chamols Company, the largest natural sponge distributor, had 90 employees in 1964.3 The majority of these workers, however, were used in the handing of synthetic sponges and chamols. By contrast, a smaller flrm had only flve employees, two of whom were employed in the office. 4

\section{Evaluation of operations}

Previous discussions have indicated that distributors, by virtue of their financial size, proxiralty to markets, and intimate contacts with most users, can be considered as the most influential group in the distribution of natural sponges. Since natural sponges constitute only one of the three main product lines carrled by these firms, one can

${ }^{I}$ Interv1ew w1th Mrs. El1zabeth Wallace, November, 1964.

2 Ib1d.

Interview w1th Edward R1ley, November, 1964.

${ }^{4}$ Interview with Robert Sinenberg, November, 1964. 
work on the a priori assumption that the effort that distributors exert in selling any of these product lines will be directly related to the contribution that the particular product line makes to total firm profits. The clarification of this point is of paramount importance for the sponge industry of Florida, Inasmuch as 1ts well-belng depends on the ageressiveness which distributors exhibit in selling Florlda-produced natural sponges. On the other hand, distributor effort behind any product line w1ll depend on the contribution that the product can make to distributor profits. This evaluation hinges on the assumption that distributors as a group are interested in maximizing their profits. Although much has been sald about the valia1ty of the profit maximization motive, ${ }^{1}$ its application here conforms very accurately to the description of distributor behavior, and 1 can be used as a means of predicting their behavior in the future. Such prediction in turn may prove very useful for Florida spongers, since under the current distribution system their wellbeing depends on the activities of distributors.

Among the three main lines carried by the distributors the absorbling comodities, synthet1c and naturel sponges, are substitutes for each other, whlle both are complementary to chamols. It follows that a rational profit-oriented businessman w11l attempt to combine his product $m i x$ in a faahion that will most favorably affect his proflts. Since both alsorblag romnodities are complementary to chamo1s, chamo1s sales wili. bo most favorably affected by the complement that sells at the lowest price.

$I_{\text {Milton }}$. Spencer and Lou1s Siegelman, Managertal Economics (Homewood, III.: R1chard D. Imw1n, 1959), pp. 125-127. 
It was pointed out previously that in most instances incentives to carry a product will be determined by the contribution that the product makes to totel profits, either by itself or in conjunction w1th other products. An attempt was made by the author to obtain Information on profitability by product lines carried by distributors, but since most businessmen consider markups on products to be confidential it was impossible to obtain such Information directly. The conclusions whlch follow are based on fragmentary information, several assumptions, and deductive reasoning. It is possible that they might not conform to some specific instances, but they are useful for purposes of analysis and prediction of future developments.

During an interview with Mr. Milton Cohn, President of the Gulf and West Indies Company, the author was told that a cellulose sponge of $6 \times 4 \times 2 \frac{1}{4}$ inch size, which is the most popular size in the market, cost the distributor 20.5 cents and was sold for 36 cents, giving the distributor a 75.6 per cent markup on cost. ${ }^{1}$ The suggested retall price for this aponge was 69 cents, although Mr. Cohn pointed out that the product ususlly sold for 59 cents or less and that discounts up to 25 per cent were customarlly given to the trade in order to make private cellulose brands more attractive than national brands. In 1963, distributors sold $\$ 1,406,382$ worth of synthet1c aponges (again see Table 30). Assuming that all synthetic sponges were of a $6 \times 4 \times 2 \frac{1}{4}$ inch size and sold for 36 cents aplece distributors sold $39,078,672$ pleces of synthet1c sponges in 1963.

Intervlew with Milton Cohn, President of Gulf and West Indies Co., Inc., New York, November 20, 1964. 
During the Harrisburg experiment participating retallers bought natural sponges of a $3-3 \frac{1}{2}$ inch diameter for 65 cents with shipment prepald. I These were small Florida Wool sponges and were bought by distributors for 35 cents apiece. This gives distributors an 85.71 per cent markup on natural sponges. This is a reliable estimate since it is based on actual figures, but the markup on sponges may differ according to the type of customer and by the size of the sponge. When intervlewed by the author, distributors mentloned several figures between 70 and 100 per cent as the average markup on natural sponges. In the absence of more reliable information an 85 per cent maxkup can be taken as a fairly accurate approximation of the actual markup on natural sponges. Since imported sponges are obtainable at a lower price and can be sold at the same price as the domestics, one would expect distributors to make a larger profit on the sales of imported sponges.

The most popular size of natural sponge is the $6 \frac{1}{2}-7$ inch size which retails for $\$ 2.70$ and costs the distributor 90 cents. ${ }^{2}$ Adding the above-derived 85 per cent markup gives $\$ 1.67$ as the price at which the distributor would sell such a sponge to the trade. This $\$ 1.67$ divided Into total distributor sponge sales of $\$ 1,207,051$ in 1963 shows that 722,785 pleces of sponges were sold in that year under the assumed conditions. A comparison of the same calculation for synthetic sponges indicates that for each plece of natural sponge sold

'Sponge and Chamois Institute, "Test Market Report," A report to the members prepared by the Sponge and Chamois Institute, New York, 1963. .. 5. (Mimeographed.)

'Interview with Milton Cuhn, November, 1954. 
distributors sold 53 pleces of synthetic sponge. Since sponges, efther natural or artificial, go with chamois like ham and eggs the artificial product had the ability to sell chamols by a ratio of better than 53 to 1 .

All distributors who are members of the Sponge and Chamols Institute sell only real chamols, which is an imporice sulwiodity. In 1962 and 1963, the United States Imported $\$ 2,358,576$ and $\$ 2,667,209$ worth of chamols, respectively. ${ }^{2}$ Table 30 indicates that merbers of the Sponge and Chamols Inst1tute sold $\$ 6,153,822$ worth of chamols in 1962. The same table indicates that chamols sold by distributors in 1963 amounted to $\$ 6,692,352$. Assuming that there were no other costs and no sales out of previously held inventory, distributors had a markup of 163 per cent in 1962 and 158 per cent in 1963 on their sales of chamois. This indicates why distributors have been w1lling to sell synthetic sponges below the customary prices. This entire concept may be demonstrated by the diagram in Figure 20.

The actual relationships involved may not be linear as pictured in the diagram. The objective of the diagram is to show a conceptual relationship, not an actual measurement. This simplification is applied to many diagrammatic explanations of demand and aupply relationships. Even if the actual relationships are of a curvelinear nature, a linear depiction shows the relationship more simply and as clearly.

IInes $A B$ and $A C$ show the familiar relationship between price and quantity, that is, as the price decreases more units are sold. The 4.

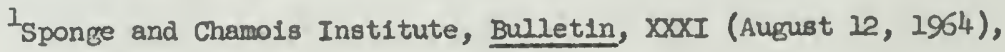


Figure 20. Relationship of Synthetic Sponge Sales to the Sales of Chamois

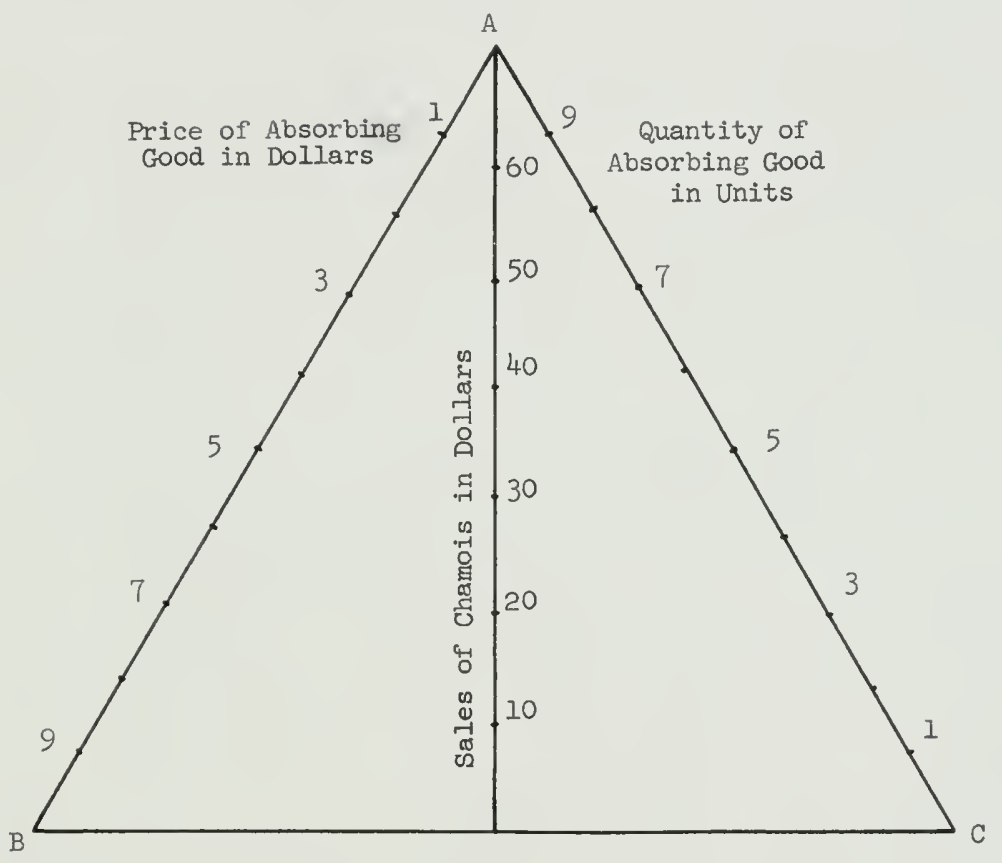

Source: Richard H. Leftwich, The Price System and Resource Allocation (New York: Holt, Rinehart \& Winston, 1961). 
vertex $A D$ measures sales volume of the complementary good; given that the price of the absorbing commodity is $\$ 9$, only one unit of 1 t will be sold and this w1ll generate an additional $\$ 10$ in sales of the complementary good. When price is lowered to $\$ 3$, seven units of the absorbing commodty will be sold and thls will generate additional sales of $\$ 50$ of the complementary good. Since synthetics were able to expand their share of the market primarily by selling at low prices, this would indicate that the product is price elastic. Users of complementary products are interested mainly in the total price for the family of products rather than the price of each individual product. Faced by high prices of Florlda sponges distributors resorted to a strategy of substitution in order not to lose their chamols business because of the rising sponge prices. Their willingness to give generous discounts on synthetic sponges is explained by the fact that such a strategy increases their sales of chamois, which provides them w1th a rather generous markup. Under these circumstances it is obvious that were 1t not for some die-hard custoners, distributors would have little incentive to push domestically produced natural sponges. ${ }^{1}$ To sumarize, the distribution channel of natural sponges originates w1th the flshermen who sell their product to the packers through the Tarpon Springs Sponge Bxchange. The product 1s sold by the packers to the distributors, who in turn sell 1 t to varlous types of users and retallers. The firms constituting the aistribution channel are of rather small size. Most of them, especlally those operating in Florida, are famly-type operations. Becruse of successive management

IInterview w1th Robert Sinenberg, November, 1964. 
Inbreeding such firms have done very little in terms of exploring new market opportunities or exerting effort to better serve their existing markets. The jority of them have historically been merely order takers and done practically nothing to stimulate demand for their product.

This chapter has traced the process of marketing sponges from the time they are caught by fishermen until their final sale. Although poor record-keeping and suspicion toward an investigator has made a great deal of information unavallable for further analysis, this is the most comprehensive treatment in existence on the subject of sponge distribution. 


\section{CHAFTER V}

\section{COMPEIIIIN}

\section{Imports}

Imports of marine sponges for consumption were 238,550 pounds valued at $\$ 1,415,571$ in 1957 (see Table 36). They dropped sharply after 1960 , and in 1963 were 82,888 pounds valued at $\$ 805,103$. Th1s drop in imports is attributable primarily to the narrowing of the price differential between domestic and imported sponges (see Table 34 ). It has been mentioned in the previous chapter that historically prices of imported sponges have usually been lower than domestic sponge prices. This differential has tended to disappear in recent years, primarily because of supply shortages encountered in the principal supplying country, Greece. Such price increases have had an adverse effect on sponge consumption, and experts are of the opinion that symthet1c sponge manufacturers w11l take over more of the market as time passes. 1

Table 35 shows United States natural sponge imports by country of origin since 1957. A cursory examination of the table shows that most American imports have come elther from the Mediterranean or the western Atlantic. In accordance wth this pattern the following paragraphs w1l deal with sponge production in the principal producing countries in the Mediterranean and the western Atlantic.

lietter from Leslie Rob1nson, Commodity-Industry Analyst for U. $S$. Tariff Comission, Washington, D. C., February 25, 1965. 


\begin{tabular}{|c|c|c|}
\hline 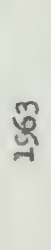 & 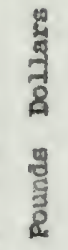 & 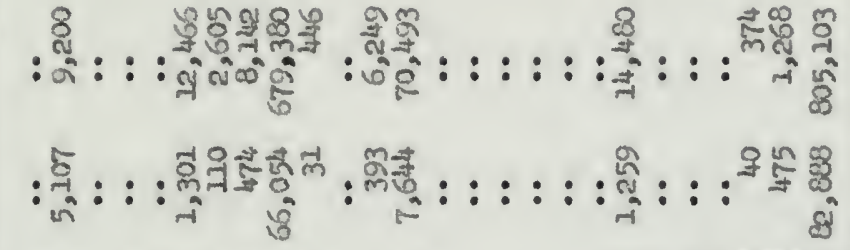 \\
\hline$\underset{r}{\mathbb{\gamma}}$ & 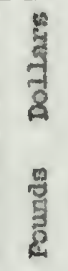 & 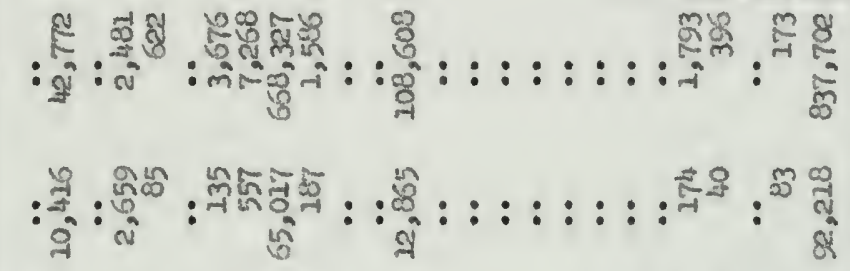 \\
\hline ఝ్ర & $\begin{array}{l}\text { है } \\
\text { है } \\
8 \\
\text { कू } \\
\text { हूँ }\end{array}$ & 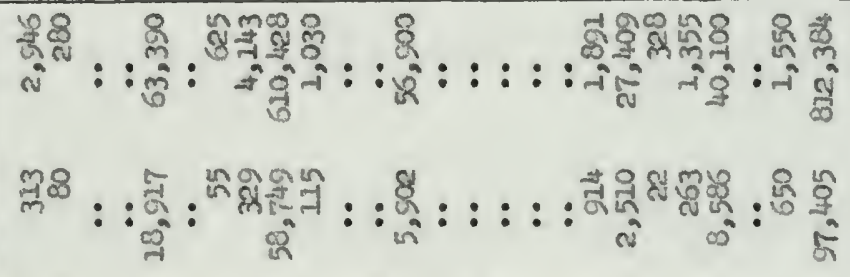 \\
\hline & $\mathrm{m}$ & Lminin $n m m$ \\
\hline
\end{tabular}



TABT: 36

UMTIBD STAFES IMPORTS OF SPCAGES BY COUMLTY OF OAIGIN, 1957-1963

\begin{tabular}{|c|c|c|c|c|c|c|c|c|c|c|c|c|c|c|}
\hline \multirow{2}{*}{ Country } & \multicolumn{2}{|c|}{1957} & \multicolumn{2}{|c|}{1958} & \multicolumn{2}{|c|}{1959} & \multicolumn{2}{|c|}{1960} & \multicolumn{2}{|c|}{1561} & \multicolumn{2}{|c|}{1962} & \multicolumn{2}{|c|}{1963} \\
\hline & Porunds & DoLlars & Poumeds & Dollars & Pounds & Dollare & Pounds & Dollars & Pounds & Dollars & Pounds & Dollars & poundes & Dollars \\
\hline $\begin{array}{l}\text { Algerta } \\
\text { Bahasias }\end{array}$ & 31,406 & $\ddot{99,899}$ & $\ddot{3,179}$ & $\ddot{7}, 615$ & $\ddot{1,586}$ & $\ddot{5,256}$ & $\ddot{2,0144}$ & $\ddot{8}, 032$ & $\begin{array}{r}313 \\
80\end{array}$ & $\begin{array}{r}2,945 \\
280\end{array}$ & 10,416 & $\ddot{2}, 772$ & $5, \ddot{107}$ & $\ddot{9}, 200$ \\
\hline Beletua & .. &.. & 968 & 1,395 & 251 & 2,753 & .. & .. & .. & .. & $\therefore$ & & .. & .. \\
\hline $\begin{array}{l}\text { Canada } \\
\text { Cubs }\end{array}$ & $84 \ddot{g} 17$ & $30 \ddot{8}, 662$ & $85, \ddot{2} c 2$ & $32 \ddot{9}, 596$ & $62, \ddot{214}$ & $24 \ddot{7}, 320$ & $76, \ddot{254}$ & 294,746 & $18, \ddot{9} 17$ & $6 \ddot{3}, 390$ & $\begin{array}{r}2,659 \\
85\end{array}$ & $\begin{array}{r}2,482 \\
622\end{array}$ & 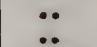 & $\because$ \\
\hline Cyprus & .. & .. & .. & .. & .. & - & .. & $\therefore$ & .. & $\cdots$ & $\because$ & $\because$ & 1,301 & 12,465 \\
\hline $\begin{array}{l}\text { Equpt } \\
\text { France }\end{array}$ & $\ddot{134}$ & $\ddot{4}, 225$ & $\ddot{2,056}$ & $2 \ddot{4,855}$ & 2,714 & $3 \ddot{B}, 309$ & $\ddot{327}$ & $\ddot{5,086}$ & $\begin{array}{r}55 \\
329\end{array}$ & $\begin{array}{r}625 \\
4,243\end{array}$ & $\begin{array}{l}135 \\
557\end{array}$ & $\begin{array}{l}3,676 \\
7,268\end{array}$ & $\frac{110}{474}$ & $\begin{array}{l}2,605 \\
8,142\end{array}$ \\
\hline Greece & 103,217 & 873,456 & 74,198 & 720,606 & 85,406 & 803,211 & 87,639 & 808,425 & 58,749 & 610,428 & 65,017 & 668,327 & $66,05 h_{4}$ & 679,380 \\
\hline Italy & 408 & 2,398 & 1,066 & 10,806 & 89 & 5,453 & 630 & 7,906 & 115 & 1,030 & 187 & 1,546 & 31 & wh \\
\hline $\begin{array}{l}\text { Jamaica } \\
\text { Japan }\end{array}$ & 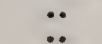 & $\ddot{.}$ & 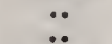 & $\ddot{. .}$ & 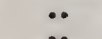 & $\ddot{*}$ & $\ddot{305}$ & $\cdots$ & $\ddot{\ddot{\prime}}$ & $\ddot{0}$ & $\ddot{*}$ & $\ddot{*}$ & $\ddot{303}$ & $\ddot{\sigma}$ \\
\hline $\begin{array}{l}\text { Japan } \\
\text { Lobanon }\end{array}$ & 13,129 & 130,187 & 23,038 & $23 \ddot{i}, 3 T^{4}$ & 4,349 & $9 i, 356$ & $\begin{array}{r}325 \\
8,534\end{array}$ & 69,818 & s,90e & $\ddot{55,500}$ & 12,065 & $10 \ddot{B}, 608$ & $\begin{array}{r}393 \\
7,644\end{array}$ & $\begin{array}{r}6,249 \\
70,493\end{array}$ \\
\hline Labye & •. & 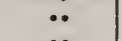 & . & .. & .. & 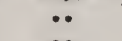 & $\because$ & $\ddot{0}$ & $\bullet$ & $\because$ & •. & •. & .. & .. \\
\hline Malta & 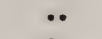 & -. & •. & $\bullet$ & $\bullet$ & $\cdots$ & 925 & 9,688 & $\cdots$ & $\cdots$ & $\cdots$ & •. & .. & $\bullet$ \\
\hline Mexico & •. & $\cdots$ & $\bullet$ & $\bullet$ & -• & $\cdot \cdot$ & 261 & 859 & $\bullet$ & •• & $\cdots$ & $\cdots$ & $\cdots$ & •. \\
\hline Phissppines & 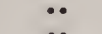 & 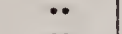 & $\bullet$ & •. & $\bullet$ & •. & •. & •. & 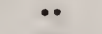 & •. & •. & •. & $\cdot \cdot$ & -. \\
\hline Spain & 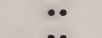 & $\ddot{*}$ & $\bullet$ & $\bullet$ & $\cdots$ & $\bullet$ & $\cdots$ & $\cdot \bullet$ & $\ddot{0}$ & 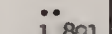 & 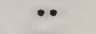 & •. & -. & -• \\
\hline Swltreriand. & $\ddot{i n 1}$ & $2 \ddot{8}, 158$ & $\ddot{0}$ & $\because$ & $\because$ & $\ddot{B}$ & 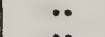 & 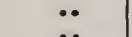 & 914 & 1,891 & -. & $\because$ & $\because$ & \\
\hline $\begin{array}{l}\text { Syria } \\
\text { mrleste }\end{array}$ & 2,121 & 20,150 & $\ddot{\circ}$ & $\ddot{0}$ & 545 & 3,500 & $\because 11$ & $\ddot{7}{ }^{3} 3$ & 2,510 & 27,409 & •. & -. & 1,259 & 14,480 \\
\hline $\begin{array}{l}\text { Triegte } \\
\text { Tun1s1s }\end{array}$ & $\ddot{\circ}$ & $\ddot{0}$ & $\ddot{*}$ & $\ddot{0}$ & $\ddot{n}$ & $\ddot{*}$ & 111 & 2,743 & 22 & $\begin{array}{r}328 \\
\end{array}$ & $\ddot{i}_{\mathrm{Th}}$ & $\ddot{i}_{703}$ & 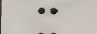 & $\ddot{*}$ \\
\hline $\begin{array}{l}\text { Tunisia } \\
\text { Turkey }\end{array}$ & $\ddot{3,158}$ & $\ddot{8}, 576$ & 2,245 & 10,885 & 20034 & $\ddot{15,633}$ & $\ddot{8} \ddot{8} 32$ & $\ddot{0}_{749}$ & $\begin{array}{r}263 \\
8,596\end{array}$ & $\begin{array}{r}1,355 \\
40,100\end{array}$ & 174 & 1,793 & •. & $\because$ \\
\hline Unt ted Kingloa & .. & .. & 55 & 582 & 42 & 870 & .. & & .. & & 40 & 395 & $\cdots_{40}$ & $\cdots 374$ \\
\hline West Gerwapy & .. & -. & 146 & 728 & 222 & 594 & 518 & 4,352 & 650 & $\ddot{i, 550}$ & ${ }^{8} 83$ & ${ }^{2} 173$ & 475 & 1,268 \\
\hline Total & 238,550 & $1,415,571$ & 191,044 & $1,338,443$ & 151,975 & $1,220,275$ & 186,511 & $1,252,764$ & 97,405 & 822,384 & 92,218 & 837,702 & 82,888 & 805,103 \\
\hline
\end{tabular}

Source: U. S., Tarlf' Camission, Mnnotated Tariff Schedules of the United States. 
Mediterranean countries

Grecce.--The principal sponge beds of Greece are located in the Cyclades and Sporades and around the Islands of Rhodes, Kalymonos, Samos, Hlydra, Kos, and Crete. Th1s area produces all species of Mediterranean sponges and 18 known for the fine sponges harvested from crevices and caves in the Aegean Sea. ${ }^{2}$

Greek sponge fishing has two seasons, summer and winter. During the sumber season most flshing is done in forelgn waters. The Greek government conducts negotiations with nearly all North African and Southern European nations in order to obtain fishing privileges for Greek sponge fishermen. ${ }^{2}$ It is estimated that more than 60 per cent of the Greek sponge catch comes from forelon waters. ${ }^{3}$

Sponge fishing is done by nude divers, hookers, fernezen divers, and machine divers. ${ }^{4}$ In the sumer of 1964, Greek spongers began to use scuba diving apparatus in sponge f1shing. 5 This apparatus consists of an oxygen tube strapped on the diver's back, a mask which protects the diver's head and eyes, and a pair of rubber fins worn on his feet to facilitate mobility under water. Although such equipment has been introduced only recently, it is anticlpated that its widespread use will have the same impact on the sponge flshing industry that the introduction of machine diving had early in the nineteenth century.

Istuart, p. 65 .

${ }^{2}$ Letter from Edward M. Cohen, Second Secretary of the American Embassy in Athens, Greece, November 17, 1964.

I Ib1d.

4N. Vokos, "Greek Sponge Flshing," Trade with Greece, V (July, 1964), 31.

5 Ibid. 
The old type of diving sult requires preparation before being put on and the help of others to dress the diver. The scaphander is always used in rotation, which means that one diver must always remain on board 1dle. Apert from this, machine diving requires expensive equipment, such as alr-pumps and diving sults, and supporting labor which adds to the cost of production. The skin diver's apparatus w1th Its special rubber suit does not require the help of others to be worn, nor does it cost as much as machine diving equipnent. The widespread adoption of this method may cut production costs considerably, assuming that nothing happens to affect the normalcy of the sponge beds.

Almost the entire Greek sponge production 1 a destined for export markets, and the sponge industry is considered as a valuable source of forelon exchange by the Greek government. ${ }^{1}$ mo assure continuity of sponge exports the Greek goverment, in addition to negotiating for fishing privileges w1th other nations, sponsored the establishrent of a diver training school on the Island of Kalymnos in $1955 .^{2}$ The existence of this school assures a steady supply of divers, and 1t acquaints trainees with safety methods and practices. Unlike the United States sponge industry most forelon operations are characterized by a rather high incidence of diving deaths and accidents. For cxample, in Greece in 1963, according to Trade whth Greece, the quarterly Journal of the Athens Chamber of Comerce and Industry, there were seventeen sponge flshing accldents, flve of which resulted in death. 3

1

Ibld.

2 Ibld.

3ro1d. 
TABLE 37

GREER SPONGE FRODUCTION, TOTAL EXPORTS, AND EXPORTS

TO THE UNITED STATES, SELECTED YEARS, 1936-1963

\begin{tabular}{|c|c|c|c|c|}
\hline Year & $\begin{array}{l}\text { Production } \\
\text { In Pounds }\end{array}$ & $\begin{array}{l}\text { A11 Exports } \\
\text { in Pounds }\end{array}$ & $\begin{array}{l}\text { Exports to } \\
\text { the U. S. } \\
\text { In Pounds }\end{array}$ & $\begin{array}{l}\text { Exports to the } \\
\text { U. S. as a } \\
\text { Percentage of } \\
\text { Totel Exports }\end{array}$ \\
\hline 1936 & 141,700 & 167,100 & 2,400 & 1.44 \\
\hline 1937 & 93,900 & 129,300 & 2,300 & 1.78 \\
\hline 1938 & 86,900 & 104,700 & 3,000 & 2.87 \\
\hline 1939 & 77,900 & 51,300 & 3,300 & 2.43 \\
\hline 1947 & 331,000 & 189,400 & 51,600 & 27.22 \\
\hline 1960 & . & $\$ 1,228,000$ & $\$ 808,425$ & 65.83 \\
\hline 1951 & $\cdots$ & $1,335,000$ & 610,428 & 45.71 \\
\hline 1952 & 194,550 & $1,267,923$ & 668,327 & 52.55 \\
\hline 1963 & 202,424 & . & 679,380 & . \\
\hline
\end{tabular}

Source: 1936-1939, 1947 from Stuart. 1960-1963 from Trade with Greece and U. S., Tariff Comission, Annotated Tariff Schedules.

awelght converted to velue after 1947.

At present Greece is the major sponge producer in the world. Table 37 shows Greek sponge production, total exports, and percentage of such exports shlpped to the United States for selected years. Although most of the Greek sponge landings are destined for forelgn markets, the amount exported 18 considerably higher than domestic production because Greek exports include domestic production plus the production bought by Greek sponge merchants from other countries. In 1964, for exæmple, Greek sponge merchants purchased 10,400 pounds of sponges from Syria, the entire Syrian production for that year, to be exported to other countries. 1

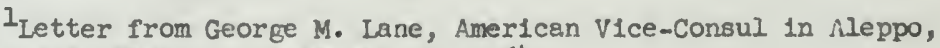
Syrian Arab Republic, December 29, 1964. 
Greece has become the most important sponge supplier of the United States. As can be seen in Table 38 in 1963,48 per cent of the total United States sponge supply came from Greece. Th1s const1tuted almost 80 per cent of total sponge imports for that year.

In 1963, the sponge f1shing fleet of Greece consisted of 103 craft. The composition of this fleet by method of operation was as follows: 78 craft engaged in machine diving, 8 trawls, 10 fernezen boats, and 7 unspecified, presumably hookers. Thls fleet was manned by 1,125 seamen of whish 583 wen were classifled as divers. ${ }^{1}$

Firathand local information from all sponge produclng countries and a survey of secondary sources show that Greece 1s the only country where sponge fishing is not considered as a declining industry. Between 1936 and 1963, Greek sponge landings increased from 141,000 pounds to 202,424 pounds, approximately 30 per cent (again see Table 37). This is in contrast to what happened in other major sponge producing countries. The superior position that the Greek sponge fisheries hold among other sponge producing nations is attributable to the following factors. (1) Unlike the sponge beds of the western Atlant1c, the Mediterranean sponge beds have been relatively imane to marine diseases. During the World War II years when western Atlantic sponge beds were being fished intensively, sponge fishing in the Mediterranean was interrupted. This interruption of fishing led to an increase in the sponge population, which was reflected in the higher amounts of landings which followed the war years. (2) H18torlcally speaking, Greek f1shermen have been very receptive to the adoption of new thods and techniques of operation. All known

IVokos, Trade wth Greece, V, 31. 
TABLE 38

SPONGE TRADE WITH GREECE, 1956-1963

\begin{tabular}{|c|c|c|c|c|}
\hline \multirow{2}{*}{ Year } & \multicolumn{2}{|c|}{$\begin{array}{c}\text { Greek Imports as a Fercentage } \\
\text { of Total Sponges Avallable } \\
\text { In the U. } \mathrm{S} \text {. }\end{array}$} & \multicolumn{2}{|c|}{$\begin{array}{c}\text { Greek Imports as a Percentage } \\
\text { of TotsI Sponge Imports } \\
\text { in the U. S. }\end{array}$} \\
\hline & Quant1ty & Value & Quantity & Value \\
\hline $\begin{array}{l}1956 \\
1957 \\
1958 \\
1959 \\
1960 \\
1961 \\
1962 \\
1963\end{array}$ & $\begin{array}{l}39.31 \\
35.48 \\
33.66 \\
45.16 \\
39.16 \\
43.74 \\
46.37 \\
47.82\end{array}$ & $\begin{array}{l}48.59 \\
52.60 \\
46.42 \\
53.53 \\
51.75 \\
51.77 \\
53.36 \\
56.98\end{array}$ & $\begin{array}{l}44.66 \\
43.27 \\
38.84 \\
52.78 \\
46.99 \\
60.31 \\
70.50 \\
79.69\end{array}$ & $\begin{array}{l}57.68 \\
61.60 \\
58.84 \\
66.23 \\
64.53 \\
75.14 \\
79.78 \\
84.38\end{array}$ \\
\hline
\end{tabular}

Source: Based on Table 36 and Table 39.

Improvements and changes in sponge flshing, such as the glass bucket, trawling, machine diving, and most recently skin diving, were elther introduced or resdily adopted by Greek sponge f1shermen. By contrast, with the exception of the United States, the remainder of the world's sponge fishing has never passed the stage of hooking. Even in the United States machine diving is a mothod practiced by Greek-Americans. (3) Becsuse of 1ts value as a source of forelgn exchange the government of Greece has played an active role in supporting the Greek aponge industry. Such support has taken the form of bilateral treatles in the negotiation of flahing privileges for Greek spongers in forelgn waters, Increased hospitalization, pension and retirement benefits for sponge divers, and the establishment of a divers' training school in Kalymnos to assure a continulty of supply of divers. ${ }^{1}$ (4) Aggressiveness ${ }^{1}$ Ib1d., pp. 32-34. 
is another factor which characterizes the creek sponge industry. When unable to harvest sponges in their national waters Greek f1shermen have not hesitated to flsh in foreign waters, even in the absence of permission to do so. 1 (5) In 1963, the average Greek diver was 25 years old. ${ }^{2}$ In other words, the average Greek diver was approximately half as old as his American counterpart. It is obvious that younger divers can descend to greater depths and stay underwater for Ionger periods. Unlike American divers who never go below 60 feet, the average diving depth for Greek fishermen 18140 feet. ${ }^{3}$ These factors have enabled the Greek sponge industry to gain a practical monopoly on the fairly inacceasible aponge beds which, as was pointed out prev1ously, are populated with sponges of the best quallty. Italy.--There is very little sponge production in Italy. 4 Italian sponge fishing is being performed on a handicraft scale and, currently, a comparatively limited number of fishermen is devoted to this activity in the areas of Leghorn, Tripani, and Torre del Greco. 5 These flshermen ut1lize self-propelled boats and two or three-pronged hooks for harvesting sponges. Italian sponge production was 5,000 pounds valued at $\$ 11,200$ in 1958. By 1963, annual sponge landings had fallen to 400 pounds at a value of $\$ 1,280$. According to information obtained from the American Embassy in Rome, Italy imported 87,780 pounds

Ietter from Cohen, November, 1964.

2Vokos, Trade with Greece, V, 31.

3 Ibid.

${ }^{4}$ Ietter from Theodore J. Hadraba, Counselor of Embassy for Commerclal Affairs of the American Embassy in Rome, Italy, November 20, 1954. 5 Ibid. 
of sponges valued at $\$ 160,000$ in 1963 . Imports do not show country of orlgin, but presumably Greece and Turkey are the main suppliers. Sponge exports in the same year totaled 32,560 pounds valued at $\$ 150,000$ and went mostly to Sw1tzerland and Japan. These latter sponges primar1ly represent imported natural sponges that were processed in Italy for export. ${ }^{1}$

Iebanon.--At present, Lebanon 1 s the second-largest producer of sponges in the Mediterranean. 2 Local consumption is negligible and export f1gures give a fairly accurate reflection of total production. Most flshing is done by hooking and fernezen diving. The latter is the method used solely by Greek Pishermen who were Imported from Greece by the firm of Massad Antakly and Company. Total Labanese exports in 1964 were estimated to be worth $\$ 174,000.3$

Syr1a.--Sponge landings in 1964 consisted of 11,000 pounds of poor quality sponges valued at $\$ 600$. All of the 1964 Syrian sponge production was sold to a Greek merchant. Because of the poor condition of the sponge beds and the uncontrolled fishing in the area the Syrian government has decreed that sponge fishing will be permitted every alternate year. 4

Turkey.--This country's sponge producing areas are scattered along the coasts of the Mediterranean and Aegean Seas off Turkey and the southern coast of the Sea of Marmara. There is practically no local demarid for sponges, and the ent1re production 1 s exported to

\section{Ib1a.}

2Letter from John c. Weisert, Commercial Attache of the American Embassy in Beirut, Lebanon, January 4, 1964.

${ }^{3}$ Ib1d.

${ }^{4}$ Letter from Lane, December, 1964. 
TABLE 39

TOTAL AVAILABLE SUPPLIES OF SPONGES IN THE UNIIED STATES FROM FRODUCIION AND IMPOAIS, 1934-1963

\begin{tabular}{|c|c|c|c|c|c|c|}
\hline \multirow{2}{*}{ Year } & \multicolumn{2}{|c|}{ Domest1c Product1on } & \multicolumn{2}{|c|}{ Imports } & \multicolumn{2}{|c|}{ Total Supply } \\
\hline & Pounds & Value & Pounds & Value & Pounds & Value \\
\hline 1934 & 485,000 & 662,000 & 479,307 & 387,730 & 964,307 & $1,049,730$ \\
\hline 1935 & 372,000 & 611,000 & 613,143 & 464,211 & 985,143 & $1,075,211$ \\
\hline 1936 & 626,000 & $1,029,000$ & 605,683 & 561,738 & $1,221,683$ & $1,590,738$ \\
\hline 1937 & 546,000 & $1,085,000$ & 581,906 & 587,620 & $1,127,906$ & $1,672,620$ \\
\hline 1938 & 521,000 & 745,000 & 428,664 & 475,238 & 949,664 & $1,220,238$ \\
\hline 1939 & 409,000 & $1,019,000$ & 431,536 & 476,035 & 840,536 & $1,495,035$ \\
\hline 1940 & 231,000 & 846,000 & 519,041 & 588,763 & 750,041 & $1,434,763$ \\
\hline 1941 & 201,000 & $1,364,000$ & 222,117 & 518,107 & 423,117 & $1,882,107$ \\
\hline 1942 & 184,000 & $1,700,000$ & 117,528 & 613,010 & 301,528 & $2,323,010$ \\
\hline 1943 & 186,000 & $2,305,000$ & 194,781 & 909,205 & 380,781 & $3,214,205$ \\
\hline 1944 & 192,000 & $2,547,000$ & 123,581 & 944,459 & 315,581 & $3,491,459$ \\
\hline 1945 & 194,000 & $2,717,000$ & 95,596 & 791,979 & 289,596 & $3,508,979$ \\
\hline 1946 & 162,000 & $2,590,000$ & 328,281 & $3,087,321$ & 490,281 & $5,677,321$ \\
\hline 1947 & 118,000 & $1,245,000$ & 208,653 & $1,674,818$ & 326,653 & $2,919,818$ \\
\hline 1948 & 74,464 & 465,937 & 355,015 & $2,587,305$ & 429,479 & $3,053,242$ \\
\hline 1949 & 68,700 & 470,580 & $242, \infty 00$ & $1,937,000$ & 310,700 & $2,407,580$ \\
\hline 1950 & 22,000 & 130,500 & 334,000 & $2,329,000$ & 356,000 & .500 \\
\hline 1951 & 15,800 & 120,755 & 252,000 & $2,142, \infty 00$ & 267,800 & $2,252,755$ \\
\hline 1952 & 25,000 & 142,100 & 278,000 & $1,248,000$ & 203,000 & $1,390,100$ \\
\hline 1953 & 17,300 & 127,916 & 258,000 & $1,628,000$ & 275,300 & $1,755,916$ \\
\hline 1954 & 15,100 & 119,179 & 191,107 & $1,124,113$ & 206,207 & $1,243,292$ \\
\hline 1955 & 34,300 & 251,100 & 216,348 & $1,341,692$ & 250,648 & $1,592,792$ \\
\hline 1956 & 29,600 & 241,566 & 217,507 & $1,291,567$ & 247,107 & $1,533,133$ \\
\hline 1957 & $4 \overline{4}, 400$ & 244,958 & 238,550 & $1,415,571$ & 282,950 & $1,660,529$ \\
\hline 1958 & 29,400 & 214,025 & 191,044 & $1,338,443$ & 220,444 & $1,552,468$ \\
\hline 1959 & 27,300 & 289,520 & 161,975 & $1,220,275$ & 189,275 & $1,509,795$ \\
\hline 1960 & 37,300 & 309,497 & 186,511 & $1,252,764$ & 223,811 & $1,562,261$ \\
\hline 1961 & 36,900 & 356,646 & 97,405 & 812,384 & 134,305 & $1,179,030$ \\
\hline 1962 & 47,981 & 415,720 & 92,218 & 837,702 & 140,199 & $1,253,422$ \\
\hline 1963 & 55,238 & 387,261 & 82,888 & 805,103 & 138,126 & $1,192,364$ \\
\hline
\end{tabular}

Source: 1934-1944 from U. S., Department of Comerce, Fore1 gn Comerce and Nav1gation of the United States; 1945-1963 from U. S., Tariff Conmission, Annotated Tariff Schedules. 
westem Europe with very little of such exports reaching the Unfted States market. In 1953, Turkish sponge exports were 112,607 pounds valued at $\$ 419,028 .^{1}$

\section{Western Atlantic countries}

From 1934 to 1939 approximately one million pounds of natural sponges per year were consumed in the United States. Imports supplied sbout 50 per cent of the total domestic consurntion (see Table 29 and Table 39). As can be seen from Table 40, before World War II Cuba and the Bahama Islands supplied almost 100 per cent of the imported naturel sponges. Taking the mean figure of the total sponge imports from 1934 to 1939 , the perlod imnediately preceding World War II, we find that the United States imported an average of 523,373 pounds of natural sponges per annum during that t1me. By applylng the same procedure to Imports from Cube and the Baharas, we find that their sponge exports to the United States averaged 322,810 and 178,849 pounds per annum respectively for the same perlod. In other words, on the average Cuba contributed 66 per cent of total sponge imports between 1934 and 1939, while approximately one-third of total United States sponge imports during that period came from the Bahamas. In 1937, a blight hit the sponge beds in the Bahamas. The same epidemic later Infected the f1shing grounds of Cuba and Florida, as has been mentioned in previous chapters. Although this disease had a disastrous effect on all known sponge beds in the western Atlantic, the Bahama beds were the hardest hlt. ${ }^{2}$ The Velvet sponges in the

Ietter from Arthur C. Iillig, Comercisl Attache of the American Embassy in Ankara, Turkey, November 20, 1954.

2stuart, p. 58. 
Bahamas were completely destroyed, and after 1937 the Bahama Is lands ceased to rank among the princlpal sponge producers of the world. ${ }^{1}$ Although no production flgures are avallable, one can reach a conclusion about Cuban sponge production after the 1937 disease by examining Cuban sponge export statistics. Since there is practically no local demand for sponges in Cubs, exported quantitles give a fairly good Indication of levels of production. United States imports from Cuba between 1940 and 1942 declined from 464,589 pounds to 101,317 pounds, a decline of approximately 77 per cent, but by 1944 Cubs was supplying more than 90 per cent of the total Unfted States sponge Imports (see Table 40). This situstion was a logical development caused by the war. When the war cut off the European markets virtually all sponge production in the western Atlantic was shipped to the United States. ${ }^{2}$

After the war the import situation underwent a drastic change. Mediterranean sponge fishing, whlch was interrupted durling the war, was resumed and expanded, primarlily by the Greek sponge fleet. ${ }^{3}$ Because of the short supply of sponges from domestlc sources and other western Atlantic nations, caused primarlly by the diseases in 1937 and 1949, imports from the Mediterranean increased tremendously. By 1949 Cuba was exporting only about 13 per cent of the total Unlted States sponge 1mports, the Bahamas about 0.2 per cent, while the remaining 87 per cent

\section{${ }^{\text {ITb1d. }}$}

${ }^{2}$ Richard A. Kahn and Lo1B B. Sandven, Sponge Production and International Sponge Trade of the Un1ted States, U. S. Fish and WIIdIffe Service Fishery Leaflet 170 (Washington: U. S. Government Printing office, 1946), p. 4.

3 stuart, p. 48. 
TARIE 40

TOTAL UNITED STATES IMPORTS FROM CUBA AND

THE BABAMAS, SELECTED YEARS, 1934-1963

\begin{tabular}{|c|c|c|c|c|}
\hline \multirow{2}{*}{ Year } & \multicolumn{2}{|c|}{ Cuba } & \multicolumn{2}{|c|}{ Bahamas } \\
\hline & Pounds & Dollars & Pounds & Dollars \\
\hline $\begin{array}{l}1934 \\
1935 \\
1936 \\
1937 \\
1938 \\
1939 \\
1940 \\
1941 \\
1942 \\
1943 \\
1944 \\
1945 \\
1946 \\
1947 \\
1948\end{array}$ & $\begin{array}{l}309,502 \\
389,167 \\
363,680 \\
315,922 \\
271,466 \\
277,124 \\
464,589 \\
185,636 \\
101,317 \\
191,636 \\
118,076 \\
62,898 \\
70,234 \\
32,098 \\
46,505\end{array}$ & $\begin{array}{l}262,813 \\
313,357 \\
387,073 \\
363,698 \\
343,783 \\
288,242 \\
503,681 \\
443,096 \\
569,620 \\
803,615 \\
899,629 \\
513,733 \\
608,154 \\
261,348 \\
235,941\end{array}$ & $\begin{array}{r}134,779 \\
192,306 \\
189,973 \\
227,056 \\
141,195 \\
187,783 \\
38,998 \\
21,662 \\
9,481 \\
572 \\
2,649 \\
87 \\
121 \\
17,686 \\
880\end{array}$ & $\begin{array}{r}55,864 \\
65,583 \\
97,039 \\
133,632 \\
68,639 \\
119,105 \\
40,351 \\
19,244 \\
17,562 \\
3,038 \\
14,652 \\
450 \\
400 \\
75,843 \\
8,970\end{array}$ \\
\hline $\begin{array}{l}1954 \\
1955 \\
1956 \\
1957 \\
1958 \\
1959 \\
1960 \\
1961 \\
1962 \\
1963\end{array}$ & $\begin{array}{c}36,850 \\
44,861 \\
71,234 \\
84,917 \\
85,262 \\
62,914 \\
76,264 \\
18,917 \\
85 \\
\ldots\end{array}$ & $\begin{array}{c}153,458 \\
162,481 \\
267,006 \\
308,662 \\
329,596 \\
247,320 \\
294,746 \\
69,390 \\
622 \\
\ldots\end{array}$ & $\begin{array}{r}\cdots \\
22,224 \\
31,406 \\
3,179 \\
1,586 \\
2,144 \\
80 \\
10,416 \\
5,107\end{array}$ & 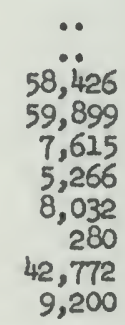 \\
\hline
\end{tabular}

Source: 1934-1944 from U. S., Department of Commerce, Fore $1 \mathrm{gm}$ Comerce and Nav1gat1on. 1945-1948, 1954-1963 from U. S., Tar1ff Commision, Annotated Tariff Schedules. 
was supplied by the countries of the Mediterranean..$^{2}$ All United States imports from Cuba were suspended on May 24, 1962, thus eliminating Cubs as a source of natural sponges. At present, sponge 1mports from the Bahamas and other western Atlantic countries constitute a very small percentage of total imports (again see Table 40), and over 90 per cent of the United States sponge Imports come from the countries of the Mediterranean. Later in this chapter recognition will be given to the fact that synthetic sponge imports from Europe affect both the natural and artificial domestic sponge market.

Excluding the United States, all sponge fishing in the western Atlantic is done by hookers. No diving equipment is used, and no deepsea fishlng has ever been attempted. ${ }^{2}$ Almost all landings are tendered to the highest bidder at public auctions and then processed and baled for export. Batabano, on the southern coast of Habana Province, is the center of the Cuban sponge Industry, while the Sponge Brchange of Nassau is considered to be the center of the sponge industry in the West Indies. ${ }^{3}$

\section{Sponge cultivation}

Because of their high regenerative power sponges can be grown from small cuttings. The discovery of sponge culture by means of cuttings is attributed to an observation made by $\boldsymbol{F}$. Cavolini in 1785

IRichard A. Kahn, The Leglislative Situation on Sponges (N.p.: U. S. Fish and Wildilfe Service, Branch of Comerc1al Fisherles, n.d.), p. [3].

$$
\begin{aligned}
& { }^{2} \text { stuart, p. } 52 . \\
& { }^{3} \text { Ibld., p. } 58 .
\end{aligned}
$$




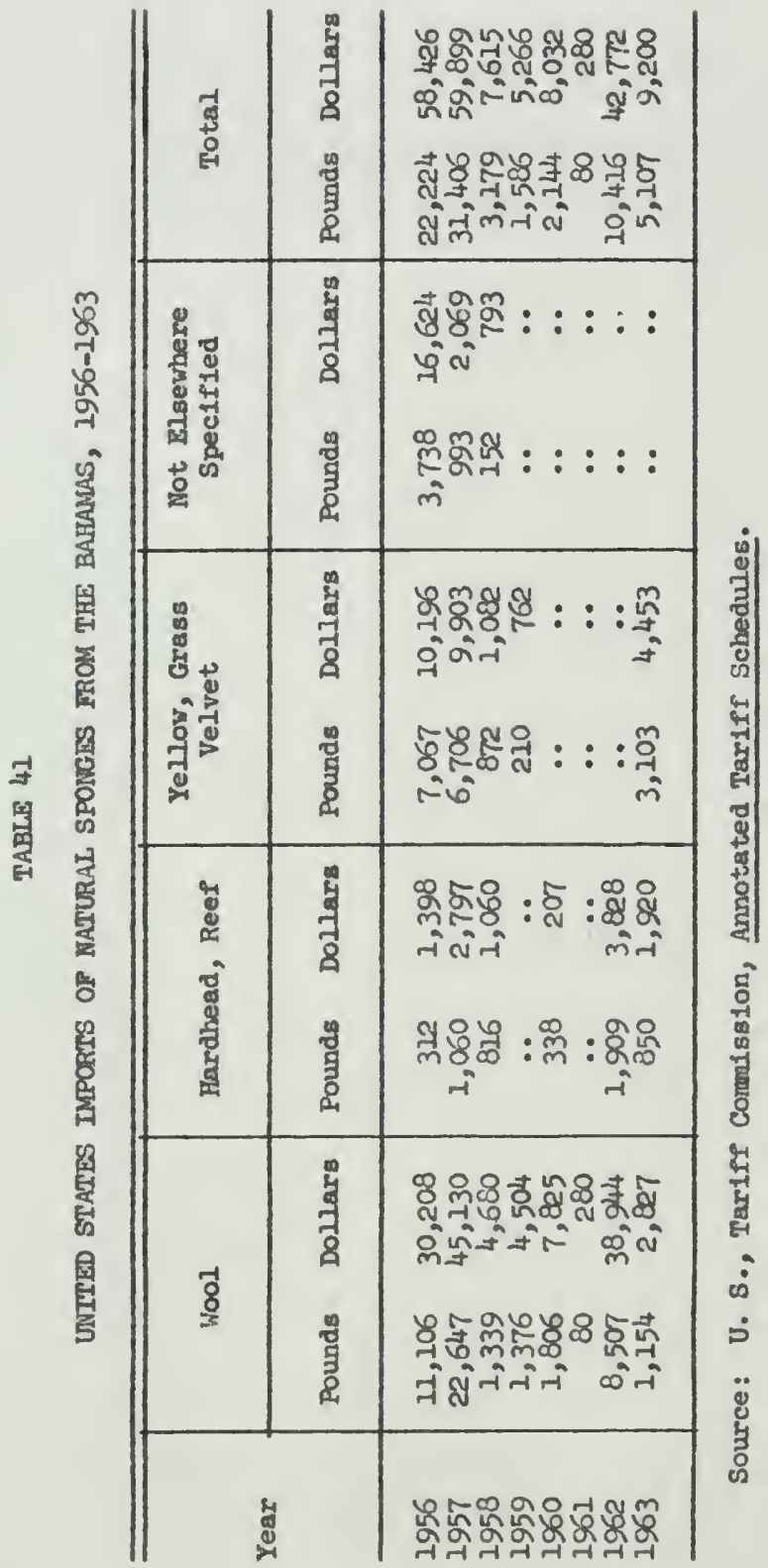




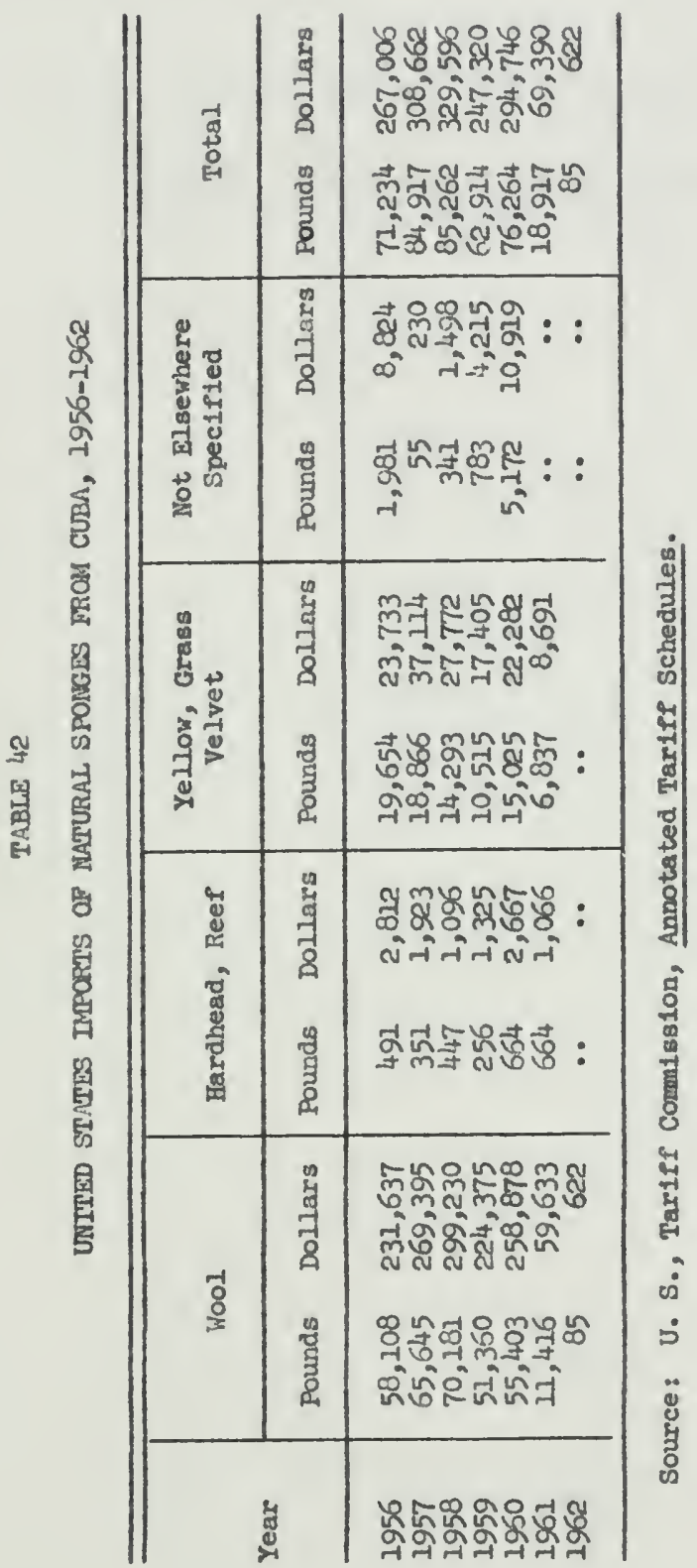


that sponges cut into pieces would attach to forelgn bodies and grow. ${ }^{1}$ A document published in 1897 mentions a Mr. J. Fogarty of Key West conducting a serles of successful experiments in propagating sponges from clippings, but the publication also hastens to add that artificial propagation of sponges did not receive much attention in Florida. ${ }^{2}$

This method was put into operation by the British colonial government in the West Indies during the early 1930's. The colonial government granted concessions to interested Individuals, permitting them to plant sponge cuttings in designated areas at Andros Island. ${ }^{3}$

The technique of sponge cultivation consists of cutting a mature sponge into segments two or three inches in diameter and attachlng the pleces to cement discs, flat rocks, stakes, or non-corrosive wires wh1ch w1ll support the sponge cuttings just above the bottom of the sea. ${ }^{4}$ The sponge must be cut with a sharp knife to avold crushing. Both the mature sponge and the cuttings must be protected from prolonged exposure to direct sunlight and must be kept in clean seawater, as rainfall or freshwater will quickly kill the sponge. 5 The 1deal bed for sponge cultivation is relatively flat, free from excessive currents, and has a norwal salt concentration. The water must be deep enough to avold disturbance of the bottom by wave action,

Moore, Proceedings of the Fourth International Fishery Congress, p. 550 .

2U. S. Congress, The F1sh and Flsherles of the Cosistal Waters of Florida, p. 9 .

3John F. Storr, The Sponge Industry of Florlda, Florids Board of Conservation Educational Serles No. 9 (Coral Gables, Fla.: Maríne Laboratory, University of Miami, 1957), p. 26.

Hiterney, p. 17.

5 Ibid. 
yet not deeper than three or four feet so that workers may plant and harvest the sponges w1 thout much difflculty. ${ }^{1}$

Artificial culture was shown to be practicable unt1l the 1937 sponge blight. From 1935 to 1937 more than 140,000 sponges were raised in the Bahamas, and more than 700,000 cuttings were planted at Turneffe, British Honduras..$^{2}$ Unfortunately, the mortality rate of 1939 was particularly high among the cultivated sponges, and the beds were almost completely destroyed. ${ }^{3}$ Also, attempts to cultivate sponges in locations appearing desirable but in which no natural sponges have been found growing have led to the discovery that starfiah and certaln types of crab prey on the young sponges and kill them.

In spite of 1 ts theoretical feasibility and recomendation by many marine biologists this approach has never recelved much attention from United States sponge fishermen, primarily because cultivated sponges have not proved to be any more frmune to marine diseases than naturally grown sponges. 5

\section{Syathetics}

Approximately 30 years ago Americans had never heard of synthet1c sponges. 6 Today better then 90 per cent of all sponges sold in the

Ibid.

2 "Sponges," Encyclopaedia Britannica.

3 Iold.

4 stuart, p. 60.

5Florida, State Board of Conservation, Ninth Blennial Report, 1949-1950, p. 46.

${ }^{6}$ Cellulose Sponge Institute, An Absorbing Story (N.p.: Cellulose Sponge Institute, n.d.), p.[2]. 
United States are made of synthetic materials. 1 They are universally used in an infinite varlety of ways around the home, in business establishments, and in various other types of activities. ${ }^{2}$

The natural sponge was the only type avallable in this country unt1l 1936 when the cellulose sponge, perfected in France in 1932, was introduced here. ${ }^{3}$ Response to the product was slow unt1l 1937 , when a blight hit the natural sponge beds in the entire western Atlant1c area. Shortly after that, World War II ended the importation of sponge supplles from the Mediterranean, and the shortage became scute. 4

The United States was faced with the problem of obtalning sponges for both milltary and civilian use, and it was then that the synthetic sponge came into the public eye. As a result of constant improvement, ample supplies, and lower prices, synthetic sponges were able to displace notural sponges from many uses in a period of approximately 30 years.

Three different kinds of synthetic sponges are currently sold in the UnIted States: vinyl, urethane, and cellulose sponges. 5

\section{Vinyl sponge}

The Simoniz Corporation was the only domestic producer of vinyl sponges. The company discontinued the production of vinyl sponges in

${ }^{1}$ Ib1d.

Ib1a.

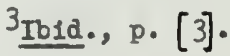

${ }^{4}$ Ib1d.

5 "Sponge Profits in a Squeeze," Chemical Week, IXC (October 27, $1962), 46$. 
1961 , and since then 1 has concentrated on the urethane variety. Today vinyl sponges constitute an insigniflcant proportion of total synthet1c sponge ales. Those found on the market are either sold from accumulated domestically produced inventorles or are of forelgn orlgin. 2

\section{Urethane aponge}

Urethane pponges are easy to produce, a fact which explains why there are so many companies producing them. ${ }^{3}$ According to Chemical Week it is concelvable that a handy do-1t-your-selfer could purchase the needed materials from a single supplier and froth up the stock in a basement tub. 4 Urethane sponges are priced below the cellulose product, but unlike cellulose sponges they do not absorb water unless totally immersed in It, and they dribble water when removed from Inmersion. 5 For this resson natural sponge alstributors and cellulose sponge producers prefer to call urethane products cleaning alds rather than sponges. As a matter of fact, some people in the aponge trade are of the opinion that urethane products have hampered rather than promoted synthetic sponge sales, because users who buy a urethane sponge and become dissatisfled with its performance may not purchase another synthetic sponge in the future. Market penetration of urethane sponges

${ }^{1}$ Ibla.

2 Ib1d.

Ibid.

${ }^{4}$ Ibid.

${ }^{5}$ Ibid. 
1s estimated to be between 10 and 15 per cent of the total synthetic sponge market, w1th 10 per cent considered as the figure closer to reality. ${ }^{1}$

\section{Cellulose sponge}

Cellulose sponges are considered to be responsible for between 80 and 90 per cent of total synthetic sponge sales. Cellulose sponge sales in the United States climbed from \$16 million in 1953 to \$31 million in 1963 (see Table 47).

Unlike the synthetic products made of vinyl and urethane, the cellulose sponge is a very close substitute for the ocean-grown sponge. Cellulose sponges soak up from 20 to 25 times their weight in water; they develop no odor; they float and can be made in any size and shape. They do not scratch smooth surfaces, are relatively long-lasting, can be dyed almost any color, are avallable in a virtually endless supply, and compared to natural sponges are very Inexpensive. These qualities of cellulose sponges, when compared to the quallties of natural sponges on pages 16-18, indicate that with the exception of durability the cellulose sponge is as functional as the natural product. As a matter of fact, several distributors are of the opinion that certsin brands of synthetic sponges are as durable as the natural product. $^{2}$ The trade also anticipates that in the future the artificial product w11l excel natural sponges even in durability. In addition to comparing favorably on a functional basis, cellulose sponges show a superiority over natural sponges in the process of marketing. Due to

\section{${ }^{1}$ Ibid.}

${ }^{2}$ Interview with Edward Riley, November, 1964. 
their wide variety of colors, attractive packaging, and ease of display, the synthetic sponge has always been given preference over the natural sponge by the majority of retailers and other middlemen. ${ }^{2}$ These characteristics, along with pricing and promotion which will be discussed later, have given the artificlal product a competitive advantage over the natural sponge.

Production.--At present, there are four domestic producers of cellulose sponges: they are Du Pont; General Mills' 0-Cello Division in Kankakee, Illino1s; Nylonge Corporation in New York C1ty; and Burgess Cellulose Company in Freeport, Illinols. ${ }^{2}$ At the time that this study was being conducted the Burgess Cellulose Company was negotlating the sale of Its cellulose sponge business to the $3 M$ Corporation of St. Paul, Minnezota. The fact that this multimillion dollar market is covered only by four manufacturers is primarily attributable to technological requirements. The technological process of cellulose sponge manufacturing is highly speclalized and requires a rather expensive capital investment. 3

The prime ingredient used in the production of cellulose sponges Is the cellulose, basically wood pulp which has been trested and refined into white sheets which resemble blotting paper. ${ }^{4}$ A second ingredient is sodium sulfate salt in crystals, made in a variety of sizes from slightly larger than a pea down to almost a powder. 5

IInterview with Robert Sinenberg, November, 1964.

2 "Sponge Profits in a 3queeze," Chemical Weuk, IXC, 43. 3 Io1d.

${ }^{4}$ Letter and unpublished material from Peter G. Kerby, Production V1ce-President of Nylonge Corp., Ner Ynrk, December 28, 1964.

5 Ibla. 
These salts make the holes in the finished product. The third ingredient is either vegetable, cotton, or hemp fiber cut to precise lengths. It acts as a binder for the cellulose and other fibers in much the same manner as the reinforcing rods used to strengthen concrete and gives the sponge greater tensile strength and resistance to abrasion. ${ }^{1}$

In making cellulose sponges the sheets of cellulose are soaked and mixed in a solution of water and then treated with carbon bisulfide and caustic soda until there is a resulting jelly-like substance called viscose. To the viscose are added the proper quantities and sizes of salt crystals and reinforcing fluers. To all this is added the dye or pigment which gives the resulting sponge blocks the desired pastel color. ${ }^{2}$ These substances are then mixed carefully in accordance with a time-tested formula which produces the proper even distribution of all the elements in complete uniformity twroughout the mass. ${ }^{3}$

The $\operatorname{mix}$ is then poured 1nto rectangular block-shaped molds, much like glant loaves of bread, and the molds are cooked unt1l the material coagulates and the cellulose is properly regenerated from the viscose complex. ${ }^{4}$ Bach step in this process is carefully controlled with rigid timing, temperatures, et cetera, as dictated by years of experience and experimentation in order to produce a uniformly hlgh-grade end product. 5

I Ib1d.

${ }^{2}$ Ib1d.

${ }^{3}$ Iold.

${ }^{4}$ Ibld.

5 Ib1d. 
During the cooking process most of the salt crystals melt and run off, leaving the holes whlch have been preplanned through the specificetion of the sizes, quant1ty, and dispersion of the salt crystals in the mixing procedure. ${ }^{l}$ Fine pore sponges are made by using only the powdered salt and smaller crystals, coarse pore sponges by using a range of crystal sizes varylng from small to large. 2 After the sponge block has been removed from the cooking mold the last vestiges of salt are removed by thoroughly wasking the hlock. which is then run through successive bleaching, washing, and softening baths and sprays. The end result is a large oblong block over a foot square and several feet long of the desired soft pastel color, resdy for slicing and packaging. The slicing is done by an automatic cutter, Insuring uniformity of length, width, and thickness in every plece of each size marketed. The packaging in plast1c or cellophane bags and shipping cases completes the process. 3

Market structure.--Desp1te the fact that there are only four producers of cellulose sponges in the UnIted States cellulose sponges can be found under a plethora of brand names. 4 W1th the exception of Du Pont all producers provide varlous types of buyers with private brands. In addition, many sponge distributors and other types of middlemen sell only imported synthet1c sponges under their own brand names. 5 For example, the Amertcan Sponge and Chamols Company in Long

1

Ib1d.

2 Tb1d.

3Ib1d.

4 "Sponge Prof1ts in a Squeeze," Chemical Week, IXC, 43. IIb1d. 
Island C1ty, New York, the largest natural sponge distributor, 1mports Its synthet1c sponges from Novacell in France and Aktlebolaget Celloplast, a Swedish company located in Stockholm. ${ }^{1}$ At this point it may be approprlate to point out that due to their confidential nature the four domestic synthetic sponge producers were extremely reluctant to provide detalled information on their operations. Most data obtained were framented and of a general nature. In order to arrive at some meaningful conclusions it was necessary to supplement such information w1th deductions and opinions of distributors and other knowledgeable people in the trade.

Invarlably private brands are priced a little lower than the customary retall prices for 1dentical synthetic sponges that have national brand labels. For example, the Nylonge Corporation produces and markets sponges under the Nylonge brand and under several other brand names, Including such well-known companies as Sears, Roebuck and Montgomery Ward.

D1str1but1on.--Correspondence and personal 1nterviews with officials of the four domestic cellulose sponge producers have ind1cated that these producers sell their product through wholesalers, automotive brokers, and major chains. Inasmuch as sponges are used primarily for cleaning purposes, distribution very much parallels that of other cleaning 1tems, such as soaps, detergents, scouring pads, and bleaches. For this reason the two smaller manufacturers admitted that their products could not be distributed as extensively as those of Du Pont and General Mills, because the latter two had a very wellestablished distribution network or cleaning products. To cope with

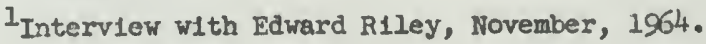


this situation the two smaller producers have tried to obtain as great a volume as possible through the use of private brands. In addition, all four producers sell sponges directly to manufacturers for conversion to various cleaning devices, such as block sponge mops, sponge cloths, soap dishes, and dish mops. Except for Du Pont all the producers market their products under both nat1onal and private brands, ${ }^{1}$ and with the exception of General Mills all producers sell sponges only in cut up sizes. General Mills sells synthot1c sponges both in blocks and cut up sizes.?

Celluiose sponges marketed under private labels are carried by many types of firms, such as department stores, mall-order houses, hardware wholesalers, and sponge distributors. Such f1rms can obtain their supplies from any domestic producer except Du Pont or from several cellulose manufacturers abroad. Most of them, especially those importing sponges from other countries, purchase cellulose sponges in loaf-like shapes several feet long, slice the oblong shaped cellulose Into consumer size sponges, package them in cellophane bags, and sell them under their own brand names.

With the exception of a few, most of these concerns are relatively amall firms with limited local markets. ${ }^{3}$ The majority of the smaller firms use forelgn sources of supply; ${ }^{4}$ however, even when they buy from

I Letter from T. G. Lynam, Household Specialties or E. I. du Pont de Nemours \& Co., W1lmington, Del., January 4, 1965.

${ }^{2}$ Letter from T. A. Schneider, Sales Manager of Chemical Division of Genersl Mills, Inc., Kankakee, III., January 8, 1965.

3 "Sponge Profits in a squeeze, Chemical Heek, IXC, 43. ${ }^{4}$ Ibid. 
domestic producers, the producers do not consider them as part of their regular channel of distribution. For example, both Burgess and Nylonge view private brand sales as a means of using excess capacity and consider such customers as competitors rather than part of their regular distribution channel. ${ }^{1}$

\section{Prices}

This feeling of antagonism between national brands and private brands is due primarily to the latter's pricing strategy. ${ }^{2}$ Despite Increases in production costs and rises in the general price level synthet1c sponge prices have not risen appreclably since forld War II. ${ }^{3}$ As a matter of fact, the tendency has been for prices to go down rather than up. Th1s deflationary price trend has been caused primarlly by the small independent firms who market synthetic sponges under private brand names. For example, a $6 \times 4 \times 2 \frac{1}{4}$ inch MAR-VMI synthet1c sponge, a brand represented by the Gulf and West Indies Company of New York C1ty, retalls for 59 cents or less in many stores where 1t is carrled. A comparable size bearing a national brand would retail for not less than 69 cents according to Mr. Milton Cohn, President of the Company.

\section{Competitive position}

In 1950, Richard A. Kahn, Chlef of the Economic and Cooperative Marketing Section of the United States Fish and Wildife Service,

\footnotetext{
ILetter from Kerby, December, 1964.

2 "Sponge Profits in a Squeeze," Chemlcal Week, IXC, 43. I Ibid.

4Interview with Milton Cohn, November, 1954.
} 
estimated that natural sponge sales at the user's level had a value of $\$ 7,080,000$, whlle synthetic sponge sales to users amounted to $\$ 13,317,800.1$ Presumably these figures include imports and domestic production. Since the two products are very close substitutes for each other one may assume that a summation of the natural and synthet1c sponge sales represents total market demand for the absorbing commodity. Based on this assumption, in 1950 natural sponges had a 34.70 per cent share of the total sponge maxket. In 1963 the composite market 1ncludIng Imports was estimated to be in the viciaity of $\$ 40$ mill1on, with natural sponges sharing approximately 10 per cent of this total.

It was pointed out previously that for many users the cellulose sponge is a very good substitute for the natural product. This 18 the opinion of the majority of distributors selling both kinds of sponges, although the two products have never been compared under sclentific laboratory conditions. Sellers of natural and synthet1c sponges are of the opinion that natural sponges are more durable than synthet1cs; however, they quickly emphasized that this superior aurability is confined only to the Rock Island variety. 3 Even if this contention is true many users elther are not aware of such a superiority or else this quality of superior durability is not considered to be important enough by them to significantly differentiate the natural product from the synthet1c. 4 As a matter of Iact, many tradespeople

IR1chard A. Kahn, "Is the Natural Sponge Fishery Doomed by Synthet1c Sponges?" Proceedings of the Gulf and Caribbean Flsherles Institute, Third Annual Session (N.p., November, 1950), p. [2].

2 "Sponge Profits in a Squeeze," Chemical Week, IXC, 43. 3 Interview w1th Edward Riley, November, 1964. ${ }^{4}$ Ib1a. 
contend that certain features of artificial sponges, such as color, shape, and avallability, make a more favorable 1mpression on the user than the durability claim of natural sponges. Since from a functional point of view the two products are considered to be substitutes for each other it follows that under these conditons user preference would be influenced primarily by price. To be sure, prices do not have to be identical, because such factors as individual tastes and preferences may induce some users to pay a bigher price for either product, but any such difference would have to be within a reasonable range. In 1950, a survey conducted by the United States Fish and Wildilfe Service among natural sponge diatributors and retallers selling natural sponges stated that 46.64 per cent of the respondents indicated high prices as the most important reason for the decline in natural sponge sales. ${ }^{1}$ According to the same survey, at that time the average unit value of natural sponges sold was $\$ 1.13$, and the unit value of synthet1c sponges was 49.3 cents. ${ }^{2}$ The surrey concluded that some customers indicated a wlilingness to pay up to 75 cents per plece for natural sponges but that beyond this price they would shift to syathetics. ${ }^{3}$

In 1954 , a $6 \times 4 \times 2 \frac{1}{4}$ 1nch good quallty synthetic sponge retalled for 59 or 69 cents, the former representing a private brand and the latter a national one. 4 Both brands could be bought for about 10 cents less p. [2].

${ }_{\text {Kahn, Proceedings of the Gulf and Caribbean Fisherles Institute, }}$

${ }^{2}$ Ib1d.

${ }^{3}$ Ib1d.

${ }^{4}$ Interview with Milton Cohn, November, 1964. 
in certain types of cut-price establishments, such as drugstores and discount houses. During the same period a Rock Island sponge of a comparable $6 \frac{1}{2}-7$ inch size retalled for $\$ 2.70$, a price difference of $\$ 2.11 .^{1}$

In 1950 , the price difference between natural and synthetic sponges was 63.7 cents por average unit value. Although the Fish and Wildife Service does not describe average un1t value, assuming that this represents a $6 \times 4 \times 2 \frac{1}{14}$ inch size for synthetics and $6 \frac{1}{2}-7$ inch size for natural sponges, which are the most popular sizes, the price difference between natural and synthetic sponges has increased by almost 30 per cent in fourteen years.

Synthetics are such close substitutes for the natural sponge that they clearly affect the elasticity of the latter. It is a well known fact that synthet1cs are being used across the country for purposes in which natural sponges were formerly ut1lized, and one need not engage In a marketing survey to prove this point. Under such conditions it is obvious that an increase in the price difference between natural and synthetic sponges would adversely affect the market share of the former. Th1s fact has been demonstrably verified by the events that have taken place during the past few decades.

\section{Imports}

Although some of the smaller firms selling synthetic sponges purchase them from foreign manufacturers, Imports have never been an important factor in this area. For example, Table 43 shows that in 1963 imports constituted an infinitesimal proportion of total

\section{Ibid.}


synthet1c sponge sales, less than 1 per cent. Th1s contrasts sharply with the natural sponge situation as shown in Table 29 where more than two-thirds of the avallable sponges were supplied through imports. There are several reasons for the inabillty of 1mports to displace the domest1c product. F1rst, unlike most f1rms that produce or sell natural sponges the synthet1c sponge industry is characterized by rather large amounts of capital investment. ${ }^{1}$ As a matter of fact, two of these firms have assets totaling millions of dollars and are consldered to be among the largest corporations in the United States. Second, the tarlff pollcy of the Unted States has afforded synthet1c sponge prolucers a degree of protection which is stronger than the protection given to natural sponge producers. A comparison of Table 44 and Table 45 shows that for each category synthetic sponges have been given better protection than natural sponges. Third, elther because of competitive pressures or deliberate policy synthetic sponge prices have been kept remarkably low since the end of world war II. ${ }^{2}$ such low prices enabled the domestic producers to penetrate the market and gave very little inducement to potential competition. Agsin, this is in sharp contrast with the natural sponge situation where in addition to avaliability the lower prices of the imported sponges have been responsible for the large influx of imports.

Marketing strategies

Unlike the natural sponge business whose products have been produced, handled, and marketed in the same way since the beginning of

l"Gponge Profits in a Squeeze," Chemical Week, IXC, 46. 2Tb1d., p. 43. 


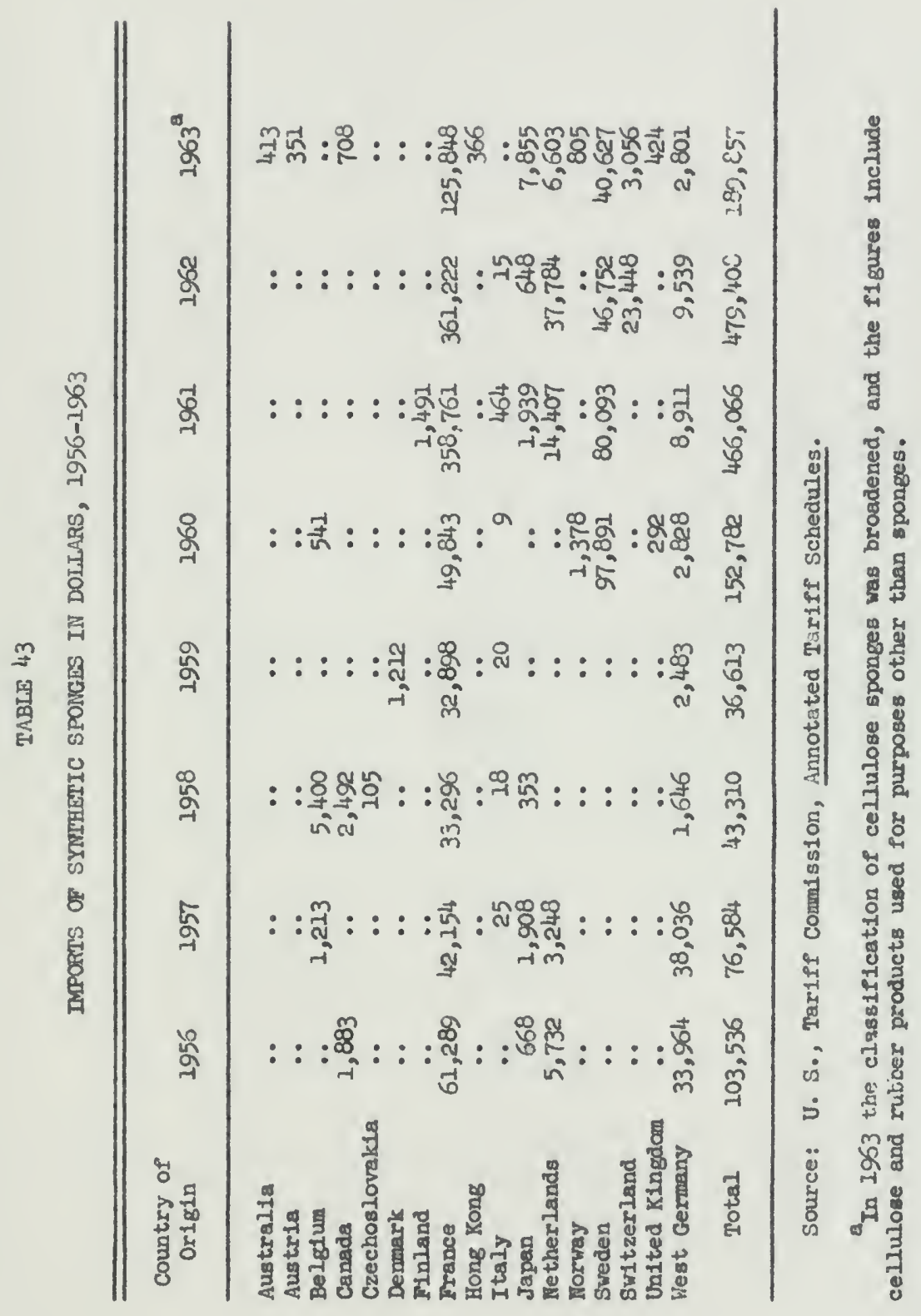


TABLE 44

MARINE SPONGES: UNITEDD STATES RATES OF DUTY EXISTING

ON JANUARY 31, 1965, AS DEFINED IN SEC. 256 (4)

OF TRE TRADE EXPANSION ACT OF 1962

\begin{tabular}{|c|c|c|}
\hline \multirow{2}{*}{ Description of Item } & \multicolumn{2}{|c|}{ Rate of Duty Bxisting January $31,1965^{\circ}$} \\
\hline & $\begin{array}{l}\text { Most Favored } \\
\text { Nation }\end{array}$ & $\begin{array}{c}\text { Commist Block } \\
\text { Countries }\end{array}$ \\
\hline $\begin{array}{l}\text { Grass, Velvet, or } \\
\text { Yellow }\end{array}$ & $7.5 \%$ ad valorem & $25.0 \%$ ad valorem \\
\hline $\begin{array}{l}\text { Sheepswool } \\
\text { Hardhead, Reef } \\
\text { Not Blsewhere } \\
\text { Speclfled }\end{array}$ & $\begin{array}{l}12.0 \% \text { ad valorem } \\
4.0 \% \text { ad valorem } \\
7.5 \% \text { ad valorem }\end{array}$ & $\begin{array}{l}22.5 \% \text { ad valorem } \\
15.0 \% \text { ad valorem } \\
15.0 \% \text { ad valorem }\end{array}$ \\
\hline
\end{tabular}

Source: U. S., Congress, Trade trpansion Act of 1962. U.S. Code congressional and Admin1strative News, 87th Cong., 2d Ses8., 1962.

apfect1ve May 24, 1962, Imports of Cuban orlein were denled the benefits of concessions contalned in any trade sgreement.

TABLE 45

SYNTHETIC SPOMGES: UNITED STAUES RATES OF DUTY EXTSTINO ON JARUARY 31, 1965, AS DEFINED IN SEC. 256 (4)

OF THE TRADE EXPANSION ACT OF 1962

\begin{tabular}{|c|c|c|}
\hline \multirow{2}{*}{ Description of Item } & \multicolumn{2}{|c|}{ Rate of Duty Existing January 31, 1965} \\
\hline & $\begin{array}{l}\text { Most Favored } \\
\text { Nat1on }\end{array}$ & $\begin{array}{c}\text { Communist Block } \\
\text { Countries }\end{array}$ \\
\hline $\begin{array}{l}\text { Polyurethane } \\
\text { Cellulose } \\
\text { Natural Rubber } \\
\text { Not Elsewhere } \\
\text { Specifled }\end{array}$ & $\begin{array}{l}12.5 \% \text { ad valorem } \\
38.0 \% \text { ad valorem } \\
12.5 \% \text { ad valorem } \\
25.0 \% \text { ad valorem }\end{array}$ & $\begin{array}{l}25.0 \% \text { ad valorem } \\
60.0 \% \text { ad valorem } \\
25.0 \% \text { ad valorem } \\
50.0 \% \text { ad valorem }\end{array}$ \\
\hline
\end{tabular}

Source: U. S., Congress, Trade Expansion Act of 1962. 
the sponge industry in the United States, the synthetic sponge Industry is characterized by a high degree of Innovation. This innovation consclousness permeates all phases of the business and is reflected In improved products, better packaging, and a constant search for new uses for the product. It has been mentioned before that many distributors and users consider synthetic sponges to be as good as the natural product. By using polyethylene wrappers it has become possible to package synthetic sponges while wet in glycerin, a factor which gives the product a softer "squeezler" feel while on display. Th1s encourages higher sales, especlally under self-service conditions. The various pastel colors of synthet1c sponges and their shape, which is conductve to unlform stocking, provide attractive displays in stores. In contrast, unt1l a few years ago all natural sponges were sold without wrapping. ${ }^{2}$ At present, natural sponges are sold wrapped in cellophane, but they still display a drab appearance in comparison with the multi-color display of synthet1c sponges. As a matter of fact, the majority of natural sponge distributors complained that the1r product is never given a decent display in most establishments. An ability to constantly discover new uses for thelr product has been another factor characterla1ng the synthet1c sponge business. For example, American Sponge and Chamols introduced the spango-sloth, a cloth-like sponge, which has replaced dishcloths and washcloths in many households. By extruding a cellulose sponge around a cotton core Du pont makes mops with spaghett1-like strands, and by attaching

$$
\begin{aligned}
& \text { IIbid., p. } 50 . \\
& { }^{2} \text { Interview with Mrs. Ellzabeth Wallace, November, } 1964 .
\end{aligned}
$$


wooden handles to sponge blocks it forms them into attractive, modernlooking dish mops. A larger size of the dish mop serves as a floor mop. Also popular is a removable sponge block attached to a mop handle with a device for squeezing water from the sponge without wetting the hands with dirty soapy water. Tiny cellulose sponges contalning a silver polish are also on the market. Hospitals are us1ng cellulose and urethane sponges as wound packing materlal in surgery, a function which formerly was performed by the natural product. ${ }^{2}$

Because of its confidential nature it was not possible to obtain deta1led information on the subject of strategy from synthet1c sponge producers; however, the examples c1ted in the above paragraphs Indicate that such firms have always capitalized on market trends in formulating their marketing strategles. For example, product improvements, such as sponge-cloths, sponges w1th silver polish, and sponge-nops, capitalize on trends of convenience, leisure, health, and beautyconsc1ousness. Innovations in pacikaging have been geared to take advantage of the self-service trend. Also, the distribution of symthetic sponges has sept up with changes in consumer-buylng habits. As opposed to the limited number of places wherc one can purchase natural sponges, syntheties can be found in supermarkets, service stations, department stores, discount houses, and variety stores. Obviously, this flexibility in distribution has greatly increased the consumer's exposure to the product. Th1s is in sharp contrast to the historically rigid distribution pattern of the natural sponge.

I"Sponge Profits in a Squeeze," Chemical Week, IXC, 50. 
Recognition and profitable exploitation of market trends by a firm implies that 1t has the ablilty to study and understand the consumer. In a consumer-oriented society the success of a business depends on how well it serves the consumer, and the quality of such service is a function of understanding the consumer. In addition to capltalizing on market trends producers of synthetics have achieved growth by constantly finding new users, such as hospltals and beauty salons, for synthet1c sponges. Unlike the natural sponge industry which is characterized by a philosophy of sticking to tradition the synthetic sponge industry reflects a strategy of planned innovation.

\section{Protection and Subsidies}

\section{Protection}

At present, cormerclal sponge resources of the United States are protected both by an act of Congress and by the laws of the State of Flor1da. The act of Congress - Public Law No. 172, approved August 15, 1914; 38 Stat. 6921 - prohibits in waters of the Gulf of Mexico and the Stratts of Florida which are outside the limits of territorial jurisdiction of Florida the capture of sponges measuring less than 5 inches in diameter when wet. This act also forbids the landing, curing, possession, or sale of sponges smaller than the established 5 inch size and provides penalties for violators. The laws of Florida contain essentially the same prohibitions with respect to catching and marketing sponges within the territorial limits of the state. State law also prohibits the use of diving equipment for takdng sponges within the territorial limits of Florida and specifles that hooks used 
in remoring sponges from the bottom of the sea be 5 inches wide (see page 26).

It can be easily inferred that the objective of these laws is to protect the species rather than the interests of the members of the sponge industry. For example, fishermen can catch all the sponges possible as long as they do not land sponges less than 5 inches in diameter when wct. Such a law may be useful for the preservation of the sponge beds, but it is of little or no benefit to certain elements of the sponge industry. As will be explained later, the interests of the sponge population, the r1shermen, and the packers and aistributors are not necessarily compatible.

Table 44 shows the current duty rates for the var1ous species of Imported sponge. A comparison of Table 44 and Table 45 shows that synthet1c sponges, which have a much superior stronghold on the United States market, have been given more protection than natural sponges. On January 24, 1955, the Sponge Industry Improvement comntttee of Tarpon Springs sent a resolution accompanied by 2,000 signatures to President Dwight Elsenhower, Senators George Smathers and Spessard Holland, and all United States Congressmen from Flcrids urging increased tariffs on iuported sponges and the prohibition of sponges less than 5 inches in diameter. "This venture was unsuccessful in increasing tarlff rates on imported sponges, but it did accomplish Its latter objective. 2

Interview with George Frantzis, President of Sponge Industry Improvement Commitee, Tarpon Springs, Fla., July, 1964.

2 Ib1d. 
Subsidies

Ifike many other troubled industries and segments of the Nmerican soclety spongers have long been trying to obtain the assistance of governmental bodles both at the federsl and state level. Heavy government purchases of natural sponges during forld War II created a prosperity among spongers which they are not $11 \mathrm{kely}$ to forget. After the cessation of host1lities, however, high prices and unreliable supplies forced the Federal Government to shlft to the use of artif1clal sponges. ${ }^{1}$ It was not unt11 1955 that through the efforts of Representative W1Illan C. Cramer the name of Flor1da natural sponges was restored to the Ceneral Services Administration catalog. 2 Table 46 shows Federal Government purchases of natural sponges since 1962. It was not possible to obtain any f1gures prior to 1962 , since such data were destroyed according to governmental policy. Table 46 Indicates that primarliy due to the pressures from veated interest groups the Federal Covernment has increased its purchases of nstural Florida sponges, but it is also apparent that government purchases of artificlal sponges have been golng up at a faster rate. For example, In f18cal year 1964 the Federal Government purchased $\$ 2,029,741$ worth of synthet1c sponges as compared to $\$ 74,195$ spent on Florida natural sponges. It is this large expenditure for synthetics that whets the appet1tes of spongers and motivates them to capture part of this business, mainly through political pressure.

Tarpon Springs lobbylsts were also successful having a law passed by the Florida Leglelature in 1963. According to this law, "all

${ }^{1}$ Ib1a.

${ }^{2}$ Ibid. 


\section{TABLE 46}

FEDERAL GOVERIMENT PURCHASES OF NATURAL AND SYNTHETIC SPONGES, SELECTED YEARS, 1948-1964

\begin{tabular}{llrr} 
Year & $\begin{array}{c}\text { Natural } \\
\text { (Dollars) }\end{array}$ & $\begin{array}{c}\text { Synthet1c } \\
\text { (Dollars) }\end{array}$ & $\begin{array}{c}\text { Rat1o of Synt } \\
\text { to Natural S }\end{array}$ \\
\hline 1948 & 23,445 & 74,703 & $3.18: 1$ \\
1962 & 44,540 & $1,903,873$ & $42.74: 1$ \\
1963 & 61,070 & $1,584,830$ & $25.95: 1$ \\
1964 & 74,195 & $2,029,741$ & $27.35: 1$
\end{tabular}

Sources: 1948 from Kahn, The Iegislative Situation on Sponges. 1962-1964 from letter from H. A. Abersfeller, General Services Administration Comissioner, January 19, 1964.

county officials, boards of county comissioners, school boards, clty counclis, city comissioners, and all other public officers of state boards and cormissions charged with the letting of contracts or the making of purchases shall, in the purchase of sponges, always specify sponges crown, cultivated or otherwise produced in Florida, whenever such sponges are svallable and price, fitness, and quality are equal." I Unfortunately, the passage of this law did not measure up to the expectations of Its proponents because of the manner in which the text was phrased. Most state officials have interpreted the term "produced in Florida" to be inclusive of synthetic sponges, and since such sponges can be obtalned at mach lower prices the synthetics have been glven preference by state purchasing agencles. As of August, 1964, no state agencles had purchased natural sponges under this law, much to the disappointment of the Florida natural sponge industry. ${ }^{2}$

\footnotetext{
IFlor1de, Statutes (1963), c. 370.162 .

2Interview w1th Goorge Arfaras, July, 1964.
} 
CHAPTER VI

CONCLUSIONS

The present chapter w11l attempt to reach some conclusions, chlefly on the basis of the analysis contalned in the previous chapters. Such conclusions in turn w1ll form the cornerstone of the recomnendations which w11l follow. Since in a free eaterprise system the fate of any economic good is determined by the interaction of factors, such as supply and demand, advertising, sales promotion, selection of channels of distribution, product image, and pricing policles, the following discussion will deal with these factors both through an examination of historical data and from information obtalned through a market experiment.

\section{Supply and Demand}

Avallability of substitutes is the most important factor determining demand elssticity. ${ }^{1}$ Inasmuch as synthetic sponges are a very good subst1tute for natural sponges, one could make an a prior 1 statement that the demand for natural sponges 18 highly elastic. Both the Kahn survey conducted in 1950 and current oplnion expressed by sponge distributors indicate that price is considered as the main factor causing sales of natural sponges to shrink. Table 34 shows that between 1952 and 1953 the average price of domest1c natural sponges

IRalph H. Blodgett, Our Expanding Economy (New York: RInehart \& Co., 1955), p. 250 . 
rose from $\$ 5.68$ to $\$ 7.39$, an increase of 30 per cent. During the same years the quant1ty of marketed domestic sponges declined by 31 per cent. As can be seen from Table 34, between 1952 and 1953 average prices of 1mported sponges were relatively stable, but the price increase in domestic sponges may have been responsible for the 45 per cent increase in imports during that period.

This s1tuation reversed 1tself exactly ten years later. Between 1962 and 1963 average import prices went up by 6.9 per cent, and th1s price Increase was accompenied by an 11 per cent decline in the quantity imported (again see Table 34 ). During the same period average dowestic prices declined from $\$ 8.66$ to $\$ 7.01$, by 19 per cent. Thls price decline coupled with hlgher import prices resulted in a 30 per cent Increase in the marketed quant1ty of domestic sponges. All these Pacts further corroborate the allegation made earlier concerning the price elasticity of the product.

The degree of price elasticity can further be demonstrated by applying the concept of cross elasticity. Cross elasticlty of demand measures the extent to which various products are subst1tutes for each other. ${ }^{1}$ If products are subst1tutes for each other the cross elasticity between them will be positive. A high crosis elasticity coefficlent would indicate that the products are close substitutes for each other. Between 1950 and 1963 sponge prices at the packers' level rose by 18 per cent (again see Table 34 ). S1nce the industry engages widely in cost plus pricing we may assume that this was reflected at the retall level. In 1950 , synthetic sponge sales

${ }^{1}$ Leftwich, p. 45. 
amounted to $\$ 13,317,800$ with an average unit price of 49.3 cents. ${ }^{2}$ Th1s means that approximately 27,013,793 units of synthet1c sponges were sold in 1950 . In 1964, synthet1c sponge sales were est1mated to be in the vicinity of $\$ 38,000,000$ with the most popular size seling for 59 cents. $^{2}$ Assuming that the 1950 price of 49.3 cents and the 1964 price of 59 cents reflect units of comparable size and value, unit sales of synthetics between 1950 and 1964 increased by 37,39R,986 pleces or by 136 per cent. Although in reality other things are seldom constant, if for the sake of demonstration one could disregard other variables the result would be a cross elasticity coefficient of 5.1. It is obvious that the existence of such a good substitute is certain to make the demand for natural sponges highly elastic. An elastlc demand coupled with high prices appears to have slowed down the turnover of nstural sponges in many selling outlets, whlch In turn has ifmited the distribution of the product. Slow turnover 18 the main complaint of all midalemen in justifying their refusal to give the product a wider market exposure. ${ }^{3}$ In advising the natural sponge industry Mr. Hugh Parker, a vice-president of the J. Walter Thompon Company, recommended wide distribution for the product, since most people buy sponges on 1mpulse. He also suggested the brand name "Triton" in order to differentiate natural sponges from subst1tutes. 4 Although this recomendation was instrumental in triggering

\footnotetext{
$1_{\text {Kahn, Proceedings of the Gulf and Carlbbeen F1sherles Inst1tute, }}$ p. [2].

${ }^{2}$ Ietter from William E. Smlth, Cellulose Sponge Institute, Chicago, December 10, 1964.
}

3 sponge and Chamois Institute, "Test Market Report," p. 12.

${ }^{4}$ Letter from Hugh Parker, Vice-President of J. Walter Thompson Company, to Theodore Cantour1s, a sponge distributor, August 27, 1963. 


\section{TABLE 47}

CETLULOSE SPONGE SALES, 1953-1962

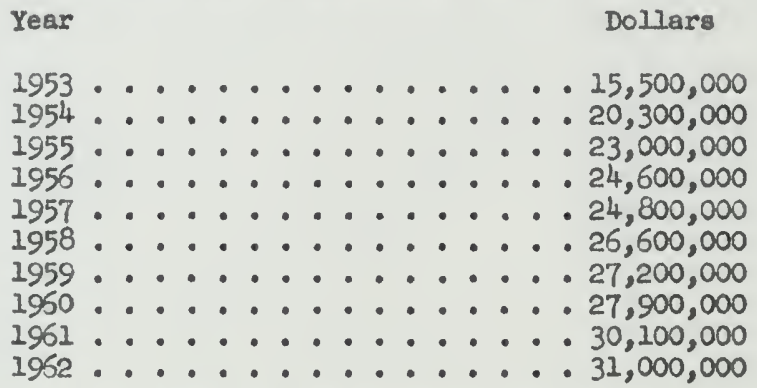

Source: Ietter from W1lliam E. Smith, Cellulose Sponge Institute, Chicago, I11., December 10, 1954.

the Harrisburg test which will be explained Iater, the Kahn survey conducted in 1950 and an examination of historical data clearly indicate that a strategy of product differentiation would be of Ilaited value in advancing the interests of the natural sponge industry.

In view of the elastic demand for the product a logical policy for attaining extensive distribution must rest upon the assumption that the supply of natural sponges is relatively elastic, but this assumption is nullified by the historical interaction of supply and demand in the industry. For example, prices of sponges have tended to rise faster than the quantity of sponges supplied whenever the demand for the commodity increased. This is most vividly illustrated in Table 48 which shows the behavior of the industry during World War II. As an increase in demand caused sponge prices to go up rapidly during the war years, the quantity of the product supplied was very unresponsive to such price changes. 
TABLE 48

ANNUAL PERCENTAGE CHANGE IN SPONGE

LANDINCS AND IN AVERAGE SPONGE PRICES, $1941-1946$

\begin{tabular}{ccccc} 
Year & $\begin{array}{c}\text { Sponge Iandings } \\
\text { in Pounds }\end{array}$ & $\begin{array}{c}\text { Average Price } \\
\text { per Pound } \\
\text { In Dollars }\end{array}$ & $\begin{array}{c}\text { Percentage Change Percentage } \\
\text { in Iandings from } \\
\text { Previous Year }\end{array}$ & $\begin{array}{c}\text { Change In } \\
\text { Price from } \\
\text { Previous Year }\end{array}$ \\
\hline 1941 & 231,000 & 3.66 & & 85 \\
1942 & 201,000 & 6.79 & -13 & 36 \\
1943 & 184,000 & 9.24 & -8 & 34 \\
1944 & 186,000 & 12.39 & 1 & 7 \\
1945 & 192,000 & 13.27 & 3 & 5 \\
1946 & 194,000 & 14.00 & 1 & \\
\hline
\end{tabular}

Source: Based on Table 10

The explanation of this s1tuation 11 es in the fact that even if It is possible to increase the number of f1shing outfits it is impossible to 1ncresse the size of the sponge population. As a matter of fact, as the number of fishing craft increases the entire level of the sponge population may go down, because competitive practices force fishermen to violate laws of conservation. An incrosse in the intensity of flshing effort, when applled to a fixed sponge population, w1ll increase the cost of flshing, which implles a rather steep supply function for the Industry as a whole. Fishermen w1ll try to pass on such cost Increases to the next buyer in the distribution channel. If each member in the channel succeeds in passing along his increased costa the f1nsl user will be faced with a higher price, which will further damage the product's market position and hurt the industry. 
It is possible that fishermen w11l have to absorb any cost increases resulting from their attempts to increase sponge landings. If this happens 1 1shermen's earaings and the returns on boat investment w11 have to go down. As f1shermen's earnings and returns on boat Investment decline labor and capital will be forced out of sponge fishing. This situation in turn w1l precipitate a shortage of f1shIng craft and personnel in the industry. It is obvious that with a reduction of operating units $1 t$ will be almost impossible to attain wide distribution as suggested by Mr. Hugh Parker. In September, 1963, the Sponge and Chamols Institute in cooperation with the Bureau of Commercial Fisheries launched the Harrisburg experiment in order to test the possiblisty of increasing natural sponge sales tbrough a more aggressive promotional effort. The c1ty of Harrisburg, Pennsylvania, was selected as a sample, because the particlpating government personnel had good contacts in the city, and the clty is located relatively close to the offlces of the Bureau of Commercial Fisherles and the Sponge and Chamols Inst1tute. The c1ty also had a good mixture of ethnic and racial groups and was considered to be fairly good from the stanipolnt of available advertising media. 1

The test mariket operation lasted two weeks and consisted of the following specific steps. The two local newspapers, the Patrlot llows and the Evening News, wth an estimated local newspapex coverage of 98 per cent spearheaded the promotion through editorial support. Spot announcements were developed and distributed to 811 eight radio stations in Harrisburg. Two local television stations, WHP and WIPA, gave the 
campalgn extensive coverage and showed slides and the fourteen minute Bureau-produced f1Im "Sponge - Treasure from the Sea." The same fllm was shown to all junfor and senior hlgh school atudents in Dauphin County. Also, 5,500 pamphlets featuring natural sponges were distributed to the students and attendants at the Meat Institute cooking school. The latter promotion was sponsored by the Meat Inst1tute and the Patriot News and was attended by approximately 4,000 homemakers. 1

In addition, a young lady from Tarpon Springs acted as an "Ambassadress of Good W111" during the last three days of the campalen. Her activities included a television sppearance, a speech at the Ifons Club, a tennis match, an appearance at the Exchange Club where she presented the Lieutenant Governor with a wreath of sponges, and visits to several retail outlets. Newspaper representatives were with the "Ambassadress of cood W111" during all her appearances and gave appropriate newspaper coverage.

rable 49 shows the participating stores together with the amount of sponges that they purchased. Sponges were packed in poly bags and retalled for 99 cents. The cost to the retaller was 65 cents with shipment prepaid. In order to give the product wide exposure it was agreed that all sponges not sold by the end of Novamber could be returned for a rull refund.

Although the Harrisburg experiment was called a marketing test by 1 ts sponsors, it was merely a poorly organlzed promotional effort. The sole purpose of the Harrlsburg experiment was to sell sponges rather than to attempt to determine cause and effect relationships

$$
\text { Ino1d., p. } 6 \text {. }
$$


which could lead to the development of a marketing plan. There was no hypothesis to be tested, nor were provisions made to control conditions pertinent to the testing of such a hypothesis. To the extent that the above conditions were not met the Harrisburg event cannot be called a marketing test. I Although Harrisburg is considered to be a fairly popular city, ${ }^{2}$ authorities in marketing believe that there is no single market area which can be representative of the entire national market. According to Professor M. S. Heidingsfleld there is no such place as a "Mldale Town, U.S.A." To the extent that a local market area fails to be representative of the entire United States market any test findings cannot be projected as applicable to the national market.

As can be seen from Table 49 the campaion to sell sponges was less than successful. Although no information on the cost of the campaign is avallable, the amount of sponges sold would be a prima facie indication that the campaign falled to accomplish its object1ve. In Its Test Market Report to the members of the Industry the Sponge and Chamols Institute reached the following conclusion:

Lower priced syathet1cs sold much better than aggressively promoted natural sponges ... Regardiess of the final results, this test market research and promotional campaign did not lack for advertising, promotion or merchandising. 4

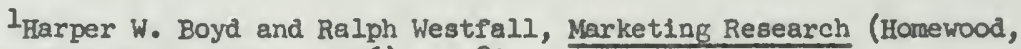
III.: Richard D. Irwin, 1956), p. 80.

2 "Test MarketIng Goes Truly National," Sales Management, November 10, 1958, p. 28 .

3yyron S. Heidingsfleld and Frank H. Eby, Jr., Marketing and Business Research (New York: Holt, Rinehart \& Winston, 1963), p. 138. ${ }^{4}$ Sponge and Chamols Institute, 'Test Market Report," p. 26. 
TABLE 49

SUMMTION OF SPONGE SALES IN HARRISBURG

Name of Store

Quantity Delivered

(Pleces)

Number of

Sponges sold

Acme Food Stores

A. \& $P$.

288

0

Food Fair

504

1,080

Town and Country Distributors

2,800

Rea and Derick Drugs

854

Peoples Drug store

720

Joe the Notorist

720

Stanley Distributing Company

S. S. Kresge Company

F. W. Woolworth

G. C. Murphy Company

Joseph Caplan Drug Coupany

B. F. Goodrich Company

Restaurant Equipment Company

H. L. Green Company

Pomeroys Department Store

Bowmans Department Store

432

432

288

216

144

144

144

144

144

144

0

0

0

0

96

25

0

27

24

8

0

0

0

52

0

0

Tota1

9,208

232

Source: Sponge and Chamois Institute, Bulletin, XXX (January 14, $1964), 3$.

Even though the above paragraph does not show any cause and effect relationships it indicates that in addition to being price elastic, the product is also highly advartising inelastic. That is, a percentage increase in advertising expenditures leads to a smaller percentage increase in sales. This would euggest that attempts to aifferentiate the product within a general market may be a total waste of time, money, and effort.

One may hazard a guess that the Harrisburg experiment might have produced dissimilar results under a different promotional approach and 
different timing. For example, had the promotion taken place in the spring rather than the fall season the results might have been more encouraging. It may be reasonably assumed that in northern climates more people would be willing to purchase sponges for cleaning and washing purposes in the spring rather than in the fall.

\section{Diatribution Structure}

At present, the established pattern for distributing Floridaproduced natural sponges consists of the following levels: flsherman to packer, packer to distributor, distributor to wholesaler or user, and wholesaler to user or retaller. This channel is rather long when compared to the distribution of aynthetics and imports. It was pointed out that synthetics are sold directly from manucturer to retaller, manufacturer to wholesaler, and mafacturer to distributor. Imports of natural sponges also move through a shorter channel, since their first contact in the domestic market is at the distributor level.

It was estimated during previous discussions that packers charge an average 25 per cent markup on cost. The markup added by distributors 18 estimated to be in the vicinity of 85 per cent. Judging by the Harrisburg experiment where sponges bought for 65 cents were sold for 99 cents, one may venture to ssy that an average retall markup would be around 52 per cent. This is close to the "normal" 50 per cent markup recomended for synthet1c sponges by the Mational Retall Hardware Association in 1 ts Turnover Handbook. ${ }^{1}$ Assuming these estimates to be fairly close to the actual practices of the businesses,

$1_{\text {Letter from Dwayne Laws, Executive Vice-President of National }}$ Reta1l Hardware Assn., Indianapolis, Ind., March 17, 1965. 
1t is apparent that a sponge sold for $\$ 1.00$ by fishermen in Tarpon Springs would cost the user $\$ 3.53$. This is a rather high markup, but it is very hard to condemn. Because of the slow turnover rate of the product most middlemen would not carry it at all if the markup were low. As a matter of fact, the National Retall Hardware Assoclation does not recomend the carrying of natural sponges because of their low turnover rate, and natural sponges are not even included in its Turnover Handbook. I The fact that distributors enjoy the highest markup in the channel is an indication that they are expected to do some aggressive selling and promoting of the product. The analysis of distributor operations in Chapter IV, however, indicates that a "push" strategy by the distributors could not be expected to succeed in view of the nature of the product lines carrled by them. One may consider the possiblifty of packers selling sponges directly to users as a device to reduce certain markups and trin prices at the user level; however, this suggestion would not be practical for two reasons. First, the discussion on packers in Chapter IV indicates that these businessmen have nefther the financial resources nor the talent to undertake such an operation. Direct selling by packers would require that they finance larger inventories, tie up some additional funds in accounts recelvable, and be prepared to cope with collection problems. Most users are located in the North and are accustomed to placing small orders by telephone and obtaining immediate delivery. It would be difficult to satisfy these needs from Florida, and the adoption of such a policy might be the last straw in 
TABLE 50

SPONGE PURCHASES FOR 1963 BY ET.EVET PACKING FIRMS IN TARPON SFRINGS, FLORIDA

Total Assets of Firm in Thousands of Dollars

Purchases in Dollars

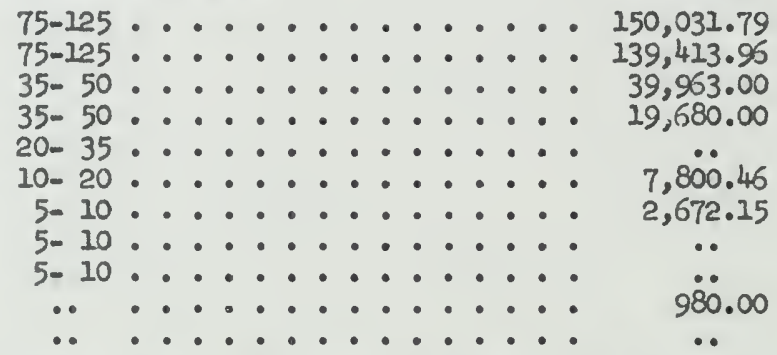

Source: Firn assets from Dun and Bradstreet. Firm purchases from survey of packers in Tarpon Springs, Fla., by the author, July, 1964.

making all users shift to synthet1cs. Second, an attempt to sell directly to users would most probably cause the packers to lose the ent1re market, since distributors are in a better position to retaliate by promoting both imported and art1ficial sponges.

Finally, the preceding paragraphs have indicated that in vlew of the limited supply function in the short run and the fact that the level of supply is very unrellable in the long run it would be economic folly to Invest money in the declining sponge Industry. The experiences of 1937 and 1949 are too fresh to forget.

\section{Product Trend}

One may deduce from the Harrisburg experiment that the natural sponge has no distinct image in the minds of the users. It may be possible to create an image for the product, but this is not very likely to succeed for two reasons. First, if the Harrisburg test is 
any indication, the amount of funds required to accomplish such an undertaking would be prohlbitively large. The second reason is the fact that the product does not possess any distinct advantages to differentiate it in the minds of the users to overcome the substantial price difference vis-a-vis the syathetics.

In addition to facing direct competition from synthetics, natural sponges have been adversely affected by improvements in other Industrles. For example, l1thographers vere once one of the best warkets for selling natural sponges, but in recent years they have shifted to the use of zinc rather than stone plates. ' This innovation has obviated the need to scrub stone plates with sponges. Spray paints have greatly reduced the consurution of sponges by painters. Before the introduction of sprays the average paint wholesaler bought 1,500 pleces of natural sponges a year. Spray paints have reduced th1s amounc to 50 pleces annuslly. ${ }^{2}$ At present, window and car washers are among the best customers of natural sponge distributors, but one would not be too far afleld to venture that Innovations, such as automatic car washing, will make inroads in these areas in the not so distant future.

Figure 21 indicetes the overall picture of the natural sponge in regard to 1 ts consumption. It depicts the trend of the product since 1951, a time which may be considered as a period of relative normalcy after the blights of 1937 and 1949. Th1s estimate assumes that all Imported and domestically produced natural sponges within any year

${ }^{1}$ Intervlew with Robert Sinenberg, November, 1964.

2Interview w1th Edward R1ley, November, 1964. 
constitute the annual consumption of the product for that year. The projected trend will deviate from specific annual flgures in the future; however, it does indicate the general direction of natural sponge consuraption. Of course, a projection based on historical experience will not be valid if unpredictable factors, such as Innovations or changes in user tastes and preferences, upset the assumptions inherent in the historical dsta. Historical precedent supplemented by logic would indicate that such trend disturbing forces are not Iikely to upset the trend of the natural sponge in 1 ts present market. As a matter of fact, if the present trend continues sponge consumption will cross the horizontal axis in a little over twenty years (again see F1gure 21). It is obvious that the future of the Florlds sponge industry is rather gloomy unless certaln basic changes are effected in order to pull the industry out of 1 tB secular decline. 
Figure 21. Least Square Straight-Line Trend of Natural Sponge Consumption in the United States

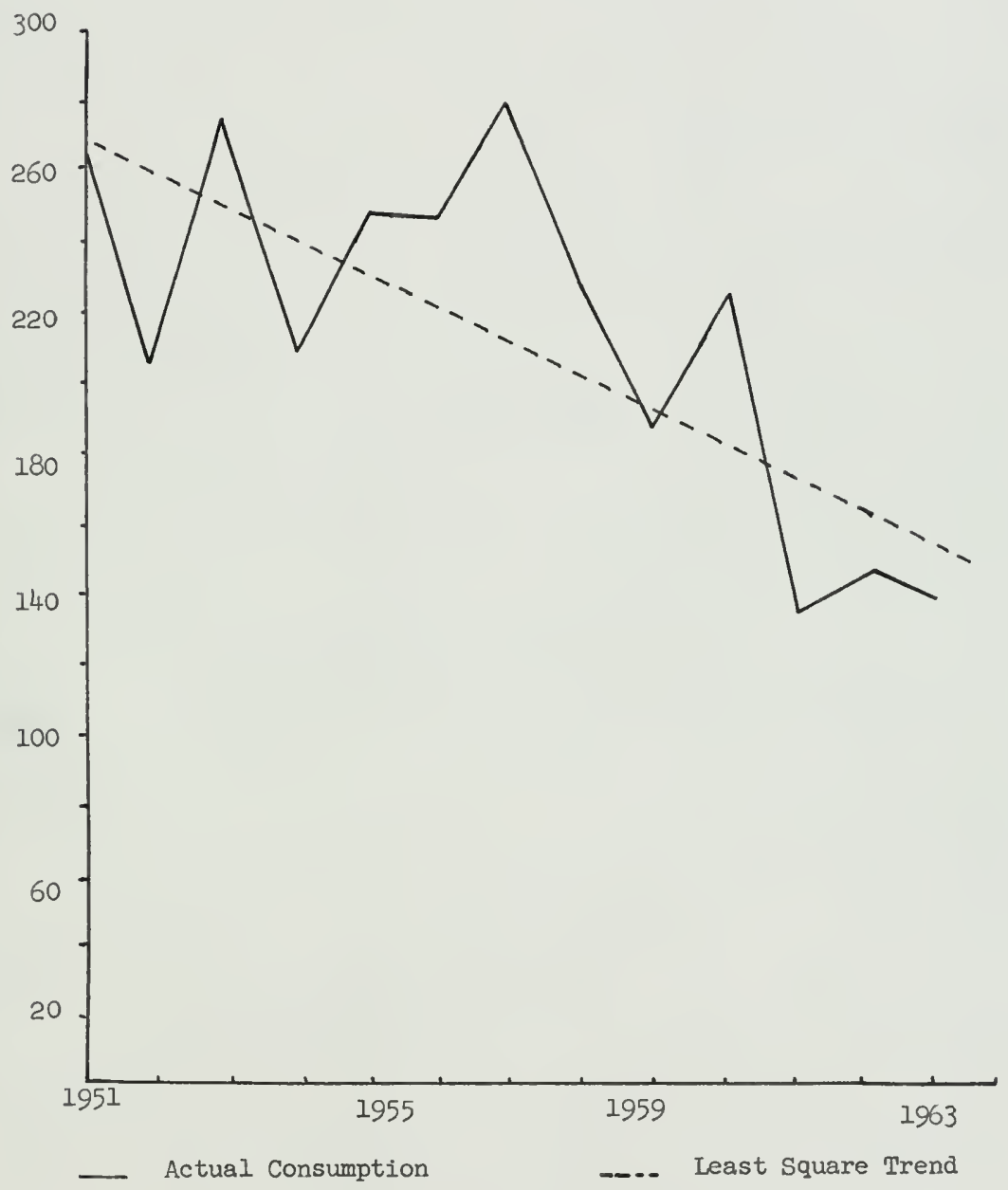

Source: Based on Table 51. 
TABLE 51

COMPUTATION OF LEAST SQUARES STRAIGHT-LTNE TREITD OF NATURAL SPONGES

Apparent

Year Consumption

\begin{tabular}{|c|c|c|c|c|c|}
\hline N & $Y$ & $\mathrm{x}$ & $x^{2}$ & $X Y$ & Ye \\
\hline 1951 & 267,800 & -6 & 36 & $-1,606,800$ & 271,562 \\
\hline 1952 & 203,000 & -5 & 25 & $-1,015,000$ & 261,932 \\
\hline 1953 & 275,300 & -4 & 16 & $-1,101,200$ & 252,302 \\
\hline 1954 & 206,207 & -3 & 9 & $-618,621$ & 242,672 \\
\hline 1955 & 250,648 & -2 & 4 & $-501,296$ & 233,042 \\
\hline 1956 & 247,107 & -1 & 1 & $-247,107$ & 223,412 \\
\hline 1957 & 282,950 & $i$ & 0 & 0 & 213,782 \\
\hline 1958 & 220,444 & 1 & 1 & 220,444 & 204,152 \\
\hline 1959 & 189,275 & 2 & $\overline{4}$ & 378,550 & 194,522 \\
\hline 1960 & 223,811 & 3 & 9 & 671,433 & 184,892 \\
\hline 1961 & 134,305 & 4 & 16 & 537,220 & 175,262 \\
\hline 1962 & 140,199 & 5 & 25 & 700,995 & 165,632 \\
\hline 1963 & 138,126 & 6 & 36 & 828,756 & 256,002 \\
\hline Totral & $2,779,172$ & 0 & 182 & $-1,752,626$ & \\
\hline
\end{tabular}
$a=\frac{\Sigma Y}{N}=213,782$
$b=\frac{\sum X Y}{X^{2}}=-9630$

Source: Based on Table 39 


\section{RECOMMENDATIONS}

The objective of the combined descriptive and analytical work in the preceding chapters was to establish the basis and lay the groundwork for the following advisory paragraphs. This flnal chapter purports to indicate possible future alternative courses of action for the sponge industry. Since the existence of clearly defined objectives is of paramount importance in recommending courses of act1on, it is appropriate to reiterate that from the outset the concern of this study has been Ilmited to the sponge Industry within the state of Florida. Therefore, the main objective of the suggested courses of action 18 to maximize those interests of the sponge industry that lie within the political furisdiction of Florlda.

\section{Narketing}

At present, the sponge interests in Florida see increased production as the sole remedy for their problem. ${ }^{1}$ No one within the industry is concerned about the marketing element. The only consciously applied marketing effort in the industry's history was the afore-mentioned abortive Harrisburg experiment. Even then one can easily deduce that the Harrisburg test trled to sell rather than market natural sponges.

Interview with Louis Smitzes, July, 1964. 
Selling Involves promoting the product through the use of salesmen and advertising; however, selling is only one of the many functlons of marketing. ${ }^{2}$ Unlike selling, which is primarlily volume orlented and seeks to promote the Interests of the seller, marketing 1 s concerned primarliy with the attainment of the firm's objectives through the satisfaction of customer needs. ${ }^{2}$ It is almost impossible to gratify customer needs w1thout making a consclous effort to find out why customers purchase a certain product and what contribution that particular product can toward the solution of the customers' personal problems. It was pointed out in the previous chapter that the objective of the Harrisburg test was to 1ncrease sponge sales. This, of course, is a rather limited viewpoint, since sales cannot be increased in a vacuum. The objective of a marketing experiment should be the discovery and measurement of factors and varlables that, if properly manipulated, could lead to better profits and increased user satisfaction simultaneously.

The preoccupation with production at the expense of marketing is typical of many unprofitable and declining industrles and product categories. ${ }^{3}$ The previous analysis of the sponge Industry indicates that increased production is not the answer to the problems of the Florida natural sponge industry.

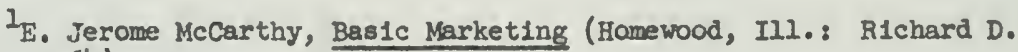
Irwin, 1964), D. 17 .

\section{To1d.: p. 26.}

3Theodore Lev1tt, "Market1ng Myop1a," Harvard Business Rev1ew, XXXVIII (July-August, 1960), 45-56. 
The distribution pattern of nstural sponges in the United States has not changed almost since the inception of the industry. Members of the distribution channel at all levels have not changed their selling methods and customary markups in spite of the dramatic changes that have taken place during the last two decades. It was pointed out previously that supply shortages prompted many users to shift to synthetics. Having the benefit of hindsight, it is easy to observe that constant product improvements and lower prices were bound to increase the market penetration of synthetic sponges at the expense of the natural product.

It is obvious that such errors comaltted in the past coupled with the physical and environmental limitations of the present have resulted in little promise for natural sponges in their current market. AccordIng to distributor opinions, which seem to have been substantiated by actusl events, an absorbing commodity is considered a shopping good by many users. 1 However, since there can be no automatic classiflcation for a product, some users, especlally household users, might look at the product as an impulse 1 tem. ${ }^{2}$ Since shopping goods have many good substitutes, most users are motivated by price alone, and this Is an area where natural sponges cannot compete with synthetics. To be sure, there are st111 some users, such as window washers, who through experience in use consider the product to be a specialty good, but distributors almost unanimously agree that this attitude is changing rapidly because of the constant product improvements in the synthetic sponge industry. ${ }^{3}$

\footnotetext{
Interview with Edward R1ley, November, 1964. 2Mccarthy, p. 393. 3Interview with Robert Sinenberg, November, 1964.
} 
Since natural sponges are unable to compete with synthetlcs in their present market, it follows that the marketing efforts of the sponge Industry should be aimed toward the creation of a new market. A new market with an inelastic demand would take the product out of price competition and transfer it from a category of shopping goods to that of a specialty good. More spec1fically, a market segmentation strategy appears to be the best insurance for the future of the industry. This Implies that the present production preoccupation of the sponge industry should change to an emphasis on marketing. Successful implementation of a market segmentation strategy presupposes the selection of a target market and the selection of appeals whlch can be most successfully employed in catering the product to the target custowers.

A strategy of market segmentation is based on the assumption that by gearing marketing effort to the satisfaction of hitherto unmet or neglected consumer requirements it is possible to achieve substantial penetration in market segments that are effectively defined. Definitions of market segments could be based elther on physical or psychological factors. In defining market segments, care should be exercised In capitalizing on a supplier's special advantages, such as location, tradition, and product, that might give him leverage in catering effectively to the desires of certain market segments. ${ }^{1}$ By recognizing and exploiting successfully defined market sepments, it is

IWIIlam Lazer and Eugene J. Kelley (ed.), Managerial Marketing: Perspectives and Viewpoints (Homewood, Ill.: Richard D. Irwln, 1962), p. 39. 
possible for a product to attain a more secure market position and greater overall stabllity. 1

Since the days of Adam Smith it has been an accepted economic principle that division of labor depends on the magnitude of a given market.2 For example, the present elongated distribution channel for natural sponges evolved during the market growth period of the industry. If an expanding distribution channel is the ususi development during the growth stages of an Industry, It may be loglcal to assume that the distribution channel should contract in a declining industry. Any contraction in the sponge industry should be at the distributor level, since previous analysis has indicated that the interests of distributors are not necessarily compatible with the interests of spongers operating in Florids. The elimination of distributors w1l take sponges out of competition in the national market. Furthermore, it was pointed out that high production costs and intermittent supplies preclude any possibilities of successful mass selling. All these factors point to the conclusion that future marketing efforts should be almed at a market within a rather narrow geographical location, which is not price conscious, which may have growth possibilities in the future, and which can be reached with a minimum of promotional effort in view of the industry's limited financial resources.

I Wendell R. Smith, "Product Differentlation and Market Segmentation as Alternative Marketing Strategles," Journal of Marketing, July, 1956, p. 8.

${ }^{2}$ Paul A. Samuelson, Economics (3rd ed.; New York: McGraw-H111 Book Co., 1955), p. 44. 
The tourists visiting Florida seem to meet all the requirements mentioned above. ${ }^{I}$ The geographicsl dimensions of the tourist market are narrow compared to the national market, since by definition they are tourists visiting Florida. Most tourista visiting the state are In a mood to purchase many souvenirs and other curios, such as coconuts and various articles made of shells, without much regard for price. For example, in 1963 tourists spent $\$ 182,369,214$ in buylng souvenirs in Florida. This category has been rising constantly as can be seen in Table 52. Since tourlat expenditures are closely related to the levels of general prosperity, constantly riaing income levels should further increase the expenditures of this group in the future. It can be seen from Tible 52 that tourism has been a growing industry In Florids. This is in sharp contrast with the declining trend of the sponge Industry. The examination and analysis of all pertinent factors in this study indicate that the domestic sponge industry has been constantly losing ground to substitute products in its present market. One can assume that the product may not have sufficient economic value to justify the continuation of industry efforts to serve its historical market. Abandoning the presently served market and concentrating on attracting the tourist market may be a more fruitful way to utilize the capital and manpower of the Florida sponge industry. Furthermore, this tourist market can be easily reached, since most visiting $t=2$ ists have already been presold on Florida. It is obvious that the tourist market presents distinct opportunities for those who recognize 1 ts existence and are prepared to serve $1 t$.

IThe ides of exploiting the Florida tourist market originated during a discussion w1th $\mathrm{Dr}$. Carter C. Osterbind, Director of the Bureau of Economic and Business Research, University of Florids. 


\section{TABLE 52}

NUMBER OF TOURISTS, TOURIST EXPENDITURES, AND TOURIST EXXPEIDITURES FOR GIFTS AND SOUVENIRS, SELECTED YEARS, 1929-1963

$\begin{array}{cccc}\text { Yumber of } & \text { Tourist Expenditures } & \text { Expenditures for } \\ \text { Tourists } & \text { (Dollars) } & \text { Gifts and Souvenirs } \\ \text { (Dollars) }\end{array}$

$\begin{array}{rrrc}1929 & 1,925,000 & 215,000,000 & \ldots \\ 1939 & 2,600,000 & 291,000,000 & \ldots \\ 1949 & 4,700,000 & 825,000,000 & \ldots \\ 1959 & 11,300,000 & 1,767,562,843 & \ldots \\ 1960 & 10,794,842 & 1,855,417,443 & 147,728,117 \\ 1961 & 12,840,230 & 2,043,266,000 & 160,851,342 \\ 1962 & 13,010,389 & 2,244,776,500 & 182,369,214 \\ 1963 & 14,208,279 & 2,522,396,000 & \end{array}$

Source: Florida, Development Commission, Tourlst Service Division, Florida Tourist Study, 1963 and Florida Handbook, 1963-1964, comp. Allen Morris (Tallahassee, Fla.: PenInsular Publishing Co., 1963).

\section{Implemertation}

Once the objective of catering to the Florlda tousist market has been adopted two different approaches are suggested to accomplish this purpose. First, the product can be sold to tourlsts throughout Florlda as a souvenir unique to the state of Florida. Second, the unlqueness of the sponge fisheries can be used to advantage in developing more tourlst trade for the entire comaunity of Tarpon Springs.

In order to sell sponges as Florida souvenirs it is suggested that a sponge flshermen's cooperative be formed. It is an old maxim in marketing that one can eliminate a middleman but not his functions. The geographical dimensions of the market and the limited number of retall outlets selling curios and souvenirs may make it possible to eliminate som of the middlemen. By avalling 1 tself of professlonal 
advice such a cooperative could sell directly to the various curio shops in Florida through the use of traveling salesmen. In view of the number of such stores located in the state (see Table 53), this activity could be performed at a reasonable cost by a single salesman. In addition, the cooperative should engage in some sort of product development through finding Imaginative applications and forms for sponges. For example, sponges might be used in a simtlar fashion to coconuts and shells in constructing souvenir Indian beads, marine sceneries, et cetera. The use of marketing research or simple brain storming may prove to be of great value in discovering new ideas.

Since fishermen have limited financlal means, the most logical promotion should be based on a pushing policy. This would imply allowing selling outlets generous markups in order to provide them with an incentive to promote the product through proper displays, billboards, and other forms of advertising.

In adition, attempts may be made to have Florlda sponges listed in the catalogs of trading stamp companies. Properly merchandised in trading stamp catalogs, natural sponges yay be made appealing to campers, automobile owmers, and homemakers. Arranging to have Florlda sponges given away by automoblle dealers to their favored customers may be another potential with great promise. A sponge worth a few dollars is not a large cost item to a dealer who has just sold a car worth several thousand dollars. All these approaches fall within the recommended market segmentation strategy and are means for 16olating the product from direct price competition.

It may be more realistic, although not ideal, to have the above suggestions Implemented by the Tarpon Springs Sponge Exchange instead 


\section{TABLE 53}

NUMBER OF SOUVENIR AND GIFT SHOPS IN FLORIDA

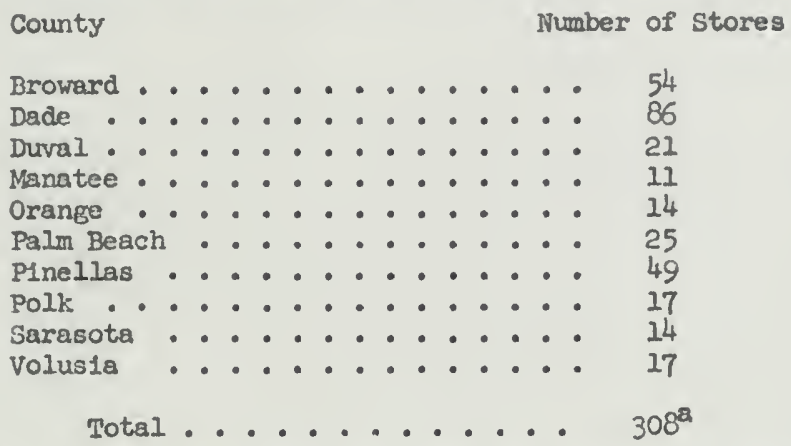

Source: U. S., Department of Commerce, County Business Patterns, First Quarter, 1962.

QThere was a total of 399 souvenis and gift shops reported for the State of Florida; however, adding the number of such shops gIven for each county results in a discrepancy of 91 shops.

of forming a fishermen's cooperative, because any approach to eliminate packers is bound to receive their resietance. In view of their influence in the local comanity, paciers acting as a group may negate the entire 1dea of creating a new market if they think their role in the selling of sponges is to be eliminated.

In using the sponge industry to develop the area as a tourlst attraction 1t may be possible to ellcit the cooperation of the local community. The citizens of Tarpon Springs already recognize the importance of the sponge industry in attracting tourists to the area; ${ }^{1}$ however, little organized effort is made by local interests to Increase tourist trade for the area by capitalizing on this unique

ITarpon Springs (Fla.) Chamber of Conmerce, The Tarpon Springs Sponge Industry, Largest in the World, p. [4]. 
Industry of the state. At present, the tourist traveling in a northsouth direction on highway U.S. 19 is the most likely prospect to stop and spend a few dollars in Tarpon Springs. The billboards advertising the Tarpon Springs sponge docks do not start until one has almost reached the city limits, and their size is much smaller than the size of other billboards competing for the motorists' attention. Beginning at a distance from Tarpon Springs, by placing large posters on main traffic arteries at frequent intervals it may be possible to get more tourlsts interested in visiting the city. Tourlst interest can further be stimulated by emphasizing the unfqueness of the sponge Industry and the fore1gn-country atmosphere of the comnunity. A sharply differentiated community image w1ll most likely attract more tourists to the area. Advertising and publiclty efforts that use the sponge industry as a theme in order to attract tourists will also Indirectly increase the sale of sponge souvenirs in Florida because of an increase in tourlst awareness of the product. Although awareness is not synonymous with sale, one ray assume that the higher the impact made by an advertisement the greater is the possibility of that advert1sement producing sales. ${ }^{1}$

\section{Production}

Chopter II described the concept of stable equilibrium in the sponge fisherles and pointed out that the present relatively high earnings of fishermen and craft owners are the result of restricted fishing effort. Under normal circumstances, flsheries do not offer much

\footnotetext{
$1_{\text {Ifelaingsfield, p. } 130 .}$
} 
opportunity for profit. ${ }^{1}$ Professor Harden F. Taylor attributes the Inablilty of fisheries to make profits to their comon property nature.

This backwardness of the fisherles industry may well be explainable by 1 ts odd nature, in which it stands alone, as an incongruous mixture of communism and capital1sm. It is communistic in the non-private or public ownership and political control and regulation of the source, but capital1st1c in the ownership of the tools of production and freedom of enterprise, and individualistic in the detached and 1solated lives that rival f1shermen live, much of the time at sea. 2

Firms or individuals in the sponge fisherles have no legal title to the natural resource. Although from a social viewpoint such natural resources are scarce, they are free goods for individual fishermen. The communistic nature of the sponge fisheries leads to wasteful compet1tion through an overexpansion of the fishing fleet, which in turn tends to put a squeeze on profits and results in needless wastage of the sponge beds as was explained in Chapter II.

The fact that industries exploiting natural resources cannot remain profitable unless properly regulated can best be demonstrated by drawing an analogy between the sponge fisheries and the petroleum Industry. Although a person may ow the piece of land on which an o1l well is bullt, he usually shares the subsurface natural resource, petroleum, with his nelghbors. ${ }^{3}$ since each surface owner has unIimfted access to the subsurface natural resource, in the absence of

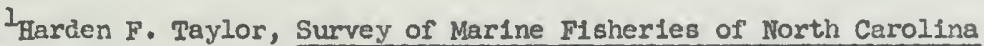
(Chapel Hill: University of North Carolina Press, 1951), p. 304.

2Toid., p. 311.

3Vernon A. Mund, Government and Business (2d ed.; New York: Harper \& Bros., 1955), p. 638. 
regulation he is impelled to drill as many wells as possible to retrieve the oil and gas before someone else can get $1 t^{1}$ In the past this common-property nature of petroleum has resulted in an overexpansion of productive facilities and unnecessary wastage of petroleum. The situation was not rectified until all the principal o1l-producing states and the Federal covernment decided to regulate and limit the production of petroleum. 2

This would suggest that a deliberate restriction of supply would be in the interest of fishermen, and 1t would tie in perfectly with the recomended strategy of market segmentation.

It is not likely that packers will be receptive to this suggestion, since an inadequate level of landings appears to be their main problem. Dollar volume is a function of quantity and price. Under the recomended marketing stratesy packers may be able to attain or Bo beyond their break-even volume at lower levels of sponge landings if higher prices can be comwanded from the newly aimed market. Sustained adequate earnings w11l also solve the industry's perennial problem of a labor shortage. By assessing operating units In return for granting a fishing permit, a controlling body, such as the Tarpon Springs Sponge Exchange or a flisherman's cooperative, can build up a fund which may be used to train the needed number of divers and other operating personnel.

\section{Adjustments}

The suggested courses of action w1ll require some adjustments at the various levels of the sponge industry, but under the above

\footnotetext{
${ }^{\text {I Ibid. }}$

2101d., p. 639.
} 
recomendations such changes will be relatively painless. The discussion of distributors has demonstrated that those firms are adjusting to the idea that natural sponges are in a decline. This situation is reflected by their present policies. Since natural sponges have become a relatively unimportant element in their product mix, a restriction of sponge landings is not likely to hurt then a great deal.

The same is true for sponge producers at the present level of craft and personnel. The limited number of operating units makes the present a very opportune time to apply the above recomendations. The demands for importing more divers are based feeling rather than analysis. The importation of additional divers is not likely to solve any problems, and it w11l undoubtedly make any future adjustments more painful.

Under the proposed remedial policies certain packers may have to accept some changes. It is possible that their business may improve in splte of reduced landings, but this will depend largely on the price level that the product will comand from its newly created markets. In all likelihood some packers may cease to be packers in the Ifteral sense of the word; however, th1s should not be a very painful adjustment since at present only three firms qualify as bona f1de packers. The rest, whether they admst it or not, have been in the process of adjust1ng their businesses to the pressures of unalterable economic forces for a long time.

To be sure, the above suggestions are merely hypotheses which generated from the analyals of the secondary and primary data collected during the course of this study. Their implementstion may not remedy the ills of the Florida sponge industry. The validity of 
these hypotheses should be tested before making a total comnltment to sell natural sponges exclusively to Florida tourists and to develop the Tarpon Springs area as a tourist attraction by ckpitallzing on the sponge pleet. No reliable marketing plan can be developed without empirically testing the importance that should be placed on the various elements in the marketing mix. These factors can only be explored through further experimental research involving the expenditure of substantial amounts of money which were not avallable to the author of this study. 
A P P E N D I E S 
APPEIDIX A

TRANSIATION FROM GREBK OF INTERVIEW GUIDE USED IN INTERVIEWTHG CRAFT CAPTAINS IN TARPOH SFRINGS, FLORIDA

CRAFT

1. Name

2. Length

3. Tonnage

4. Age

5. Price at which owmer would consider selling craft

6. Market value of equipment

PERSONNEL

7. Number of crew

8. Number of owners or partners in crew

9. Age and nationality of divers

\section{OPERATIONS}

10. Method of fishing

11. Approximate number of

Hooking diving days spent in fishing

12. Approximate number of hours worked per day while fishing

13. Distance or grounds flohed from shore

14. V:lue of landings in 1963

OPERATING COSTS III 1963

15. Fuel and oil

16. Food and supplies

17. Diving suits

18. Boat painting and repair

19. Engine repair

20. Annual depreciation 
APPENDIX B

TRANSLATION FROM GREEK OF INTERVIEW GUIDE USED IN INTERVIEWING SPONGE PACKRRS IN TARPON SPRINGS, FLORIDA

1. Name of f1rm

2. Legal form of business

3. Number of years in business

4. Member of Tarpon Springs Sponge Exchange

Yes No

5. Engaged in business

other than sponge packing

Yes No

6. If yes, type of such business

7. Sponge sales as a percentage of total sales

8. Total number of employees

Full-time Part-time

9. Number of employed relatives Full-time Part-time

10. Type of cmployment Clerical Other

11. Average employee wages Hour Week Month

12. List five most important sponge buyers (distributors)

\section{Name of Pirm}

a.

b.

c.

a.

e.
Location

Average volume purchased

13. Estimated material cost of packing a bale. 
14. Is there any seasonality in selling sponges?

Yes No

15. What are your annual sponge sales on the average

Dollars Pounds

16. Are sponge clipplings a total waste? Please explain.

17. Importance of government in the sponge market. Federal

State

Other

18. What do you think of the sponge legislation recently enscted by the Florida Ieglslature?

19. Estimated investment in: Land

Building

Equipment

20. In your opinion how can the sponge industry be improved? 



\section{BIBLIOCRAPHY}

\section{Public Documents}

Florida. Development Comission, Tourist Service Division. Florida Tourist Study, 1963. 1964.

Flor1da. State Board of Conservation. The Conservation Law. Revised and Indexed by Greene S. Johnston, Jr., 1935.

Flor1da. State Board of Conservat1on. Minth Blennial Report, 19491950. 1950.

Flor1da. State Board of Conservat1on. Second Blennial Report, Blennlum Ending June 30, 1936. 1936.

Flor1da. Statutes (1914). c. 253.692.

Florida. Statutes (1963). c. 370.162 .

U. S. Bureau of Conmercial Fisherles. Florida Landings. January, 1961October, 1964.

U. S. Bureau of Comerclal F1sheries. Unlted Ststes F1sher1es, 1962.

C. F. S. No. 3471, Annual sunmary.

U. S. Congress. The F1sh and F1sherles of the Cosstal Waters of Flor1da. Document No. 100. 54th Cong., 2d Ses8., 1897.

U. S. Congress. Trade Expansion Act of 1962. U. S. Code Congressional and Administrative News. 87th Cong., 2d Sess., 1962.

U. S. Congress. House of Representatives. House Miscellaneous Reports IV. House Report 2120. 81st Cong., 2d Ses8., 1950.

U. S. Department of Commerce. County Bus1ness Patterns. F1rst Quarter, 1962.

U. S. Department of Commerce. Forelgn Commerce and Nav1gation of the United States. 1934-1944.

U. S. F1sh and Wildilfe Serv1ce. U. S. F1shery Stat1st1cs. 1937-1962.

U. S. Tariff Comnission. Annotated Tariff Schedules of the United States. 1945-1948, 1954-1963. 
Books

Bennett, Robert B. Background Information for Voluntary Grade Standards on Natural Sponges. (U. S. Pish and WIIdlife Service Speclal Sclentiflc Report, Fisheries No. 273.) Washington: U. S. Government Printing office, 1958.

Blodgett, Ralph H. Our Expanding Economy. New York: Rinehart \& Co., 2955.

Boulding, Kenneth E. Economic Analys1s. 3rd ad. New York: Harper \& Bros., 1955.

Boyd, Harper W., and WestPall, Ralph. Marketing Research. Homewood, I11.: Richard D. Irwin, 1956.

Cobb, John N. The Sponge F1shery of Florida in 1900. (U. S. Commission of Fish and Fisheries extract from U. S. Fish Commision Seport for 1902.) Washington: U. S. Government Printing office, 1903.

Dawson, Charles E., Jr. A Survey of the Tampa Bay Area. (Florida Board of Conservation Technicsl Serles No. 3.) Tallahassee, Fla.: Florida Board of Conservation, 1953.

Dun and Bradstreet. Reference Book, 1964. New York: Dum \& Bradstreet, 1954.

Florlda Fandbook, 1963-1964. Complled by Allen Morr1s. TrIlahassee, Fla.: Peninsular Publiahing Co., 1963.

Frantz1s, Ceorge. Strangers at Ithaca. St. Petersburg, Fla.: Great outdoors Publishing Co., 1962.

Galtsoff, Paul S. Sponges. (U. S. Fish and WIIdlife Service Flshery Leaflet 490.) Washington: U. S. Government Printing office, 1960.

G1tlow, Abraham I. Labor Economics and Industrial Relations. Homewood, I11.: Richard D. Irwin, 1957.

Heldingsfleld, Myron S., and Bby, Frank H., Jr. Marketing and Business Research. New York: Folt, Rinehart \& Winston, 1903.

Idyl1, Clarence P. How Can Stat1stics Increase the Catch? (Florida Board of conservation Educational Series 1 . . 3.) coral Gables, Fla.: Marine Laboratory, University of Miaml, 1949.

Kahn, Richard A., and Sandven, Lols B. Sponge Production and Internatlonal Sponge Trade of the United States. (U. S. Flsh and Widdife Service Fishery Leaflet 170.) Washington: U. S. Goverment Printing office, 1946. 
Lazer, W1lliam, and Kelley, Eugene J. (ed.) Managerial Market1ng: Perspectives and Vleupolnts. Homewood, Ill.: RIchard D. IFWIn, 1962.

Leftwlch, RIchard H. The Price System and Resource Allocation. New York: Holt, Rinehart \& Winston, 1961.

Marine Laboratory, University of Mami. Survey of the Sponge Grounds North of Anclote Iight. Tallahassee, Fla.: Florids Board of Conservation, 1948.

Mark $15: 36$

Marshal1, Alfred. Princlples of Economics. 8th ed. Iondon: Macmillan Co., 1922.

McCarthy, E. Jerome. Bes1c Marketing. Homewood, III.: R1chard D. Irwin, 1964.

Mund, Vernon A. Government and Business. 2d ed. New York: Harper \& Bros., 1955 .

Murray, A. T. The Illad. Cambridge: Harvard University Press, 1935.

Murray, A. T. The Odysey. Cambridge: Harvard University Press, 1931.

Osterbind, Carter C., and Pantier, Robert A. Economic Study of the Shrimp Industry in the culf and South Atlantic States. Galnesville, Fla.: Bureau of Economlc \& Business Research, University of Florida, 1965.

Osterblad, Carter C. Florida's Commerclal Flsherles: Narkets, Operations, outlook. (State Econonlc Studies No. 7.) Galnesvilie, Fla.: Bureau of Economic \& Business Research, University of Plor1da, 1955.

Ovenden, A. E. Costs of Earnings Invest1gations of Primary Flshing Enterprises. (FAO Flsherles Study llo. 10.) Rome: Food and AEriculture organization, 1961.

Samuelson, Paul A. Economics. 3rd ed. New York: McGraw-H11l Book Co., 1955.

Sloan, Harold S., and Zurcher, Arnold J. A Dictionary of Economics. New York: Barmes \& Noble, 1958.

Smith, Hugh M. Notes on the Florida Sponge Fishery in 1899. (House Documents, Bulletin of the U. S. Fish Commssion, Vol. XIX for 1899.) Washington: U.S. Government Printing office, 1901.

Spencer, MLIton H., and Slegelman, Louls. Managerial Economics. Homewood, Ill.: Rlchard D. Imw1n, 1959. 
Storr, John F. Ecology of the Gulf of Mexico Comercial Sponges and Its Relation to the Fishery. (U. S. Fish and Widlife Service Special Sclentific Report, Fisherles No. 466.) Washington: U. S. Government Frinting Office, 1964.

Storr, John F. The Sponge Industry of Flor1da. (Florida Board of Conservation Educational Series Wo. 9.) Coral Gables, Fla.: Marine Laboratory, University of Miami, 1957.

Stuart, A. H. World Trade in Sponges. (U. S. Department of Commerce Industrial Series No. E.) Washington: U. S. Government Printing office, 1948 .

Taylor, Harden F. Survey of Marine Fisherles of Nortb Carolina. Chapel H111: University of North Carolina Press, 1951.

Thomas' Reg1ster of Nanufacturers, 1964. New York: Thamas Publ1shing Co., 1964.

Tierney, J. Q. The Sponge Industry of Florida. (Florida Board of Conservation Educational Series No. 2.) Coral Cables, Fla.: Marine Laboratory, University of Mami, 1949.

\section{Articles and Perlodicals}

"Ca1sson D1sease," Nat1onal Encycloped1a, $1945 \mathrm{ed.,} \mathrm{II,} 346$.

"Florida C1trus Sets Three-Year Holding Campaign," Advertising Age, XXXIV (May 20, 1963), 101.

Harr1s, J. E. "Sponge Fishermen of Tarpon Springs," Nationsl Geographic Magazine, XCL (January, 1947), 119-136.

Huttner, Natthew. "Deep Water Farmers," Argosy, CCCXXIII (December, 1946), 28-30.

Key, Alexander. "Treasure on the Ocean Floor," Saturday Eventng Post, cCxTV (June 20, 1942), 12-13.

Lev1tt, Theodore. "Marketing Kyopia," Harvard Business Rev1ew, xXXVIII (July-August, 1960), 45-56.

Moore, H. F. "The Commerc1al Sponges and the Sponge Fisher1es," Proceedings of the Fourth International Flohery Congress: Organlzation and Sessional Business, Papers, and Dlscussions (U. S. Department of Commerce and Labor, Bulletin of the Bureau of F1sheries, Vol. XXVIII, Fart I of 1908 Washington: U. S. Government Printing Office, 19107), 399-585.

Munroe, Kirk. "Sponges and Spongers," Scribner's Magazine, XXII (November, 1892), 628-639. 
Peatt1e, D. C. "From Tarpon Springs to Tub," Nature Magazine, IV (January, 1929), 43-45.

Smlth, Wende11 R. "Product Differentiation and Market Segmentation as Alternative Marketing strategles," Journal of Marketing, July, 1956, pp. 3-8.

Sponge and Chamols Inst1tute. Bullet1n. Vols. XXX-XXXI. New York: Sponge \& Chamols Institute, 1963-64.

"Sponge Profits in a Squeere," Chemical Week, IXC (October 27, 1962), 43-51.

"Sponge," Nat1onal Encycloped1a, 1945 ed. IX, 352-353.

"Sponges," Encyclopaedia Br1tannica, 1963 ed., XXI, 248-255.

"Sponges for War," Business Week, Apr11 10, 1943, pp. 30-31.

Stephens, William M. "A Remarkable AnImal - The Sponge," Sea Frontiers, $\mathrm{X}$ (February, 1964), 15-23.

Stuart, A. H. "Synthet1c Sponges, Sweden, United KIngdom, and the Netherlands," World Trade in Commodst1es, VII, Part XVIII, Special Products, No. 15 (August, 1949), 1-4. (U. S. Department of Commerce, Offlce of International Trade Publication.)

"Test Marketing Goes Truly National," Sales Menagement, November 10, 1958, pp. 28-36.

Vokos, N. "Greek Sponge Flohing," Trade with Greece, V (July, 1964), 29-34. (Quarterly Journal of Athens Chamber of Comerce and Industry.)

Pamplifets and Reprints

Cellulose Sponge Inst1tute. An Absorbing Story. N.p.: Cellulose Sponge Institute, n.d. (Unpaged.)

Kahn, RIchard A. "Is the Natural Sponge F1shery Doomed by Synthet1c Sponges?" Proceedings of the Gulf and Carlbbean Fisheries Institute, Third Annusi Session. N.p., November, 1950. (Unpaged reprint.)

Kahn, Richard A. The Leg1slative S1tuation on Sponges. N.p.: U. S. Fish and Wildilfe Service, Branch of Comercial Fisheries, n.d. (Unpaged.)

Tarpon Springs (Fla.) Chamber of Commerce. The Tarpon Springs Sponge Industry, Largest in the World. Tarpon Springs, Fla.: Tarpon Springs Chamber of Cormorce, n.d. (Unpaged.) 
Unpubl1shed Material

Lewis, Cladin. "A History of the Sponge Industry of Florida." Unpublished Master's thesis, Stetson University, 1934.

Lovejoy, Gordon W1Iliams. "The Greeks of Tarpon Springs." Unpubl1shed Master's thesis, University of Florida, 1938.

Plnelias County, Florida. F. E. R. A. Project No. 52-F2-31. (Iypewritten.)

Protcs, Ceorce D. "The Sponge Industry of Tarpon Springs." UnpubIlshed paper in the files of P. K. Yonge Ifibrary of Florida History, Unlversity of Florida, n.d. (Typewritten.)

Sage, Fred K. "Sponge Industry Sumary Report." Pinellas County, Fla., C. W. A. Project 52-89. (Mimeographed.)

Sponge and Chamols Inst1tute. "Test Market Report." A report to the members prepared by the Sponge and Chamols Institute, New York, 1963. (Mimeographed.)

"A Survey of the Sponge Industry." F. E. R. A. Project No. 52-7-31. (Typewritten.)

Writers' Program. "Sponge Industry in Flor1da." Unpublished paper in the files of the P. K. Yonge Library of Florida History, University of Florida, n.d. (Typewritten.)

Ietters

Abersfeller, H. S., General Services Adminlstration Comissioner, Washington, D. C. January 19, 1965.

Cohen, Edward M., Second Secretary of the American Embsssy in Athens, Greece. November 17, 1964.

Hadraba, Theodore J., Counselor of Embassy for Conmerclal Affa1rs of the Amrican Embassy in Rome, Italy. November 20, 1964.

Ilter, Can1p, Director of the Fourth Department of the Turieish Minlstry of Conserce in Ankara, Turkey. January 5, 1965.

Kerby, Peter C., Production V1ce-President af Hylongo Corp., Kew York. Dccember 28, 1964.

Lane, George $\mathrm{H}_{2}$, American-V1ce Consul in Aleppo, Syrian Arab Republic. December 29, 1964.

Laws, Dwayme, Execut1ve Vice-President of National Retall Bardware Assn., Indlanapol18, Ind. March 17, 1965. 
Ifllig, Arthur C., Comerclal Attache of the American Embassy in Ankara, Turkey. November 20, 1964.

Lynam, T. G., Household Specialties of E. I. du Pont de Nemours \& Co., Hilmington, Del. January 4, 1965.

Parker, Hugh, V1ce-President of J. Walter Tharpson Co., to Theodore Cantour1s, a sponge distributor. August 27, 1963.

Roblnson, Leslie, Comodity-Industry Analyst for U. S. Tariff Commission, Washington, D. C. Febmuary 25, 1965.

Schnelder, T. A., Sales Manager of Chemical Division of Ceneral Kills, Inc., Kankakee, IIl. January 8, 1965.

Smith, W1lliam E., Cellulose Sponge Inst1tute, Chicago. December 10, 1964.

Welsert, John C., Conmercial Attache of the American Habassy in Belrut, Iebanon. January 4, 1965.

\section{Intervlews}

Albee, E. R., District Sales Representative, General Mills, Inc., Atlanta, Ga. January 28, 1965.

Arfaras, George, owner of George Arfaras Packing Firm, Tarpon Springs, Fla. Nay-July, 1964.

Cohn, Milton, President of Gulf and West Indies Co., Inc., New York. November 18-20, 1964.

Frantz1s, George, President of Sponge Industry Improvement Comittee, Tarpon Springs, Fla. July, 1964.

Gielourakis, Nick, owner of Mick Glalourakis Packing Firm, Tarpon Springs, Fla. May, 1964.

Kouremet1s, John, owner of John Kouremet1s Pack1ng Firm, Tarpon Springs, Fla. Kay, 1964.

Leonard, Arthur P., International Trade Specialist, U. S. Department of Comanerce, Atlanta, Ga. February 8, 1965.

Riley, Edward, Presldent of American Sponge and Chamols Co., Long Island C1ty, N. Y. November 19, 1964.

Samarkos, John, Captain of the diving craft "Elent," Tarpon Springs, Fla. May-June, 1964.

Samarkos, Mike, owner of Samarkos Brothers, Ins., Trarpon Springs, Fla. May, 1964. 
Sinenberg, Robert, partner in Florida Sponge and Chamols Co., New York. November 18, 1964.

Smitzes, Louls, President of Tarpon Springs Sponge Exchange, Tarpon Springs, Fla. April-July, 1964.

Wallace, Mrs. Elizabeth, Executive Secretary, Sponge and Chamols Inst1tute, New York. November 16-20, 1964.

Other Sources

Sponge and Chamois Institute records (In the files of the Institute).

Survey of distributors conducted by the Sponge and Chanois Institute, 1964.

Survey of nine diving craft captains in Tarpon Springs, Fla., conducted by the author, May, 1964.

Survey of packers in Tarpon Springs, Fla., conducted by the author, July, 1964. 


\section{BIOGRAPHICAL SKGTCH}

John Vas1l Petrof was born January 6, 1933, in Istanbul, Turikey. In September, 1953, he jolned the Turkish arma from which he was discharged in 1955 as a First Lieutenant. He came to the Unfted States in 1956 to attend Emory University Irom which he recelved the degree of Bachelor of Arts in June, 1958. In June, 1959, he was awarded the degree of Master of Business Adrinistration by the same institution. From 1959 to 1962 he was employed as an Instructor by the Atlante University School of Business Administration. In 1962, be enrolled in the Graduate School of the University of Florida in order to pursue his work toward the degree of Doctor of Philosophy in Economics and Business Adminlstration. He worked as an interim-instructor in the Department of Economics unt1l May, 1963, and was awarded a Department of Interfor fellowship the following academic year. In September, 1964, he returned to Atlanta University to work as a Resource Development Specialist for the newly established Reglonal Economic Derelopment and Business Service Center.

John Vasil Petrof is married to the former Barbara Jean Gainey and is the father of two children. He is a member of the American Association of University Professors, American Economic Association, American Marketing Association, and the Soclety for the Advancement of Management. 
This dissertation was prepared under the direction of the chairman of the candidate's supervisory conmittee and has been approved by all members of that committee. It was submitted to the Dean of the College of Business Administration and to the Graduate Council, and was approved as partial fulfillment of the requirements for the degree of Doctor of Philosophy.

June 20, 1967

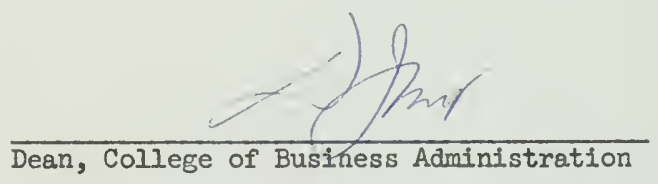

Dean, Graduate School

Supervisory Committee:

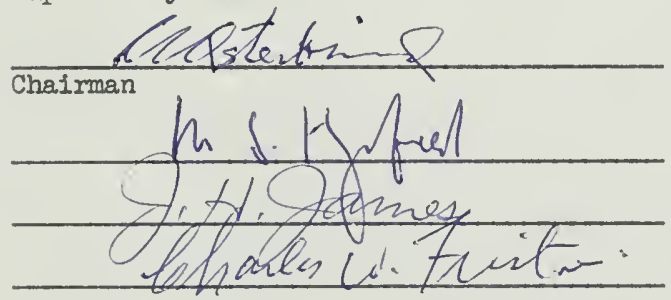




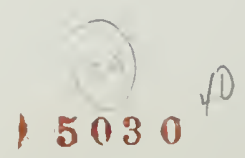

